\title{
100-D Area Technical Baseline Report
}

RECEN1,

SEP $2>1993$

O S T I

Prepared for the U.S. Department of Energy Office of Environmental Restoration and Waste Management

\section{(28) Westinghouse \\ (W) Hanford Company Richland, Washington}

Hanford Operations and Engineering Contractor for the

U.S. Department of Energy under Contract DE-AC06-87RL10930 


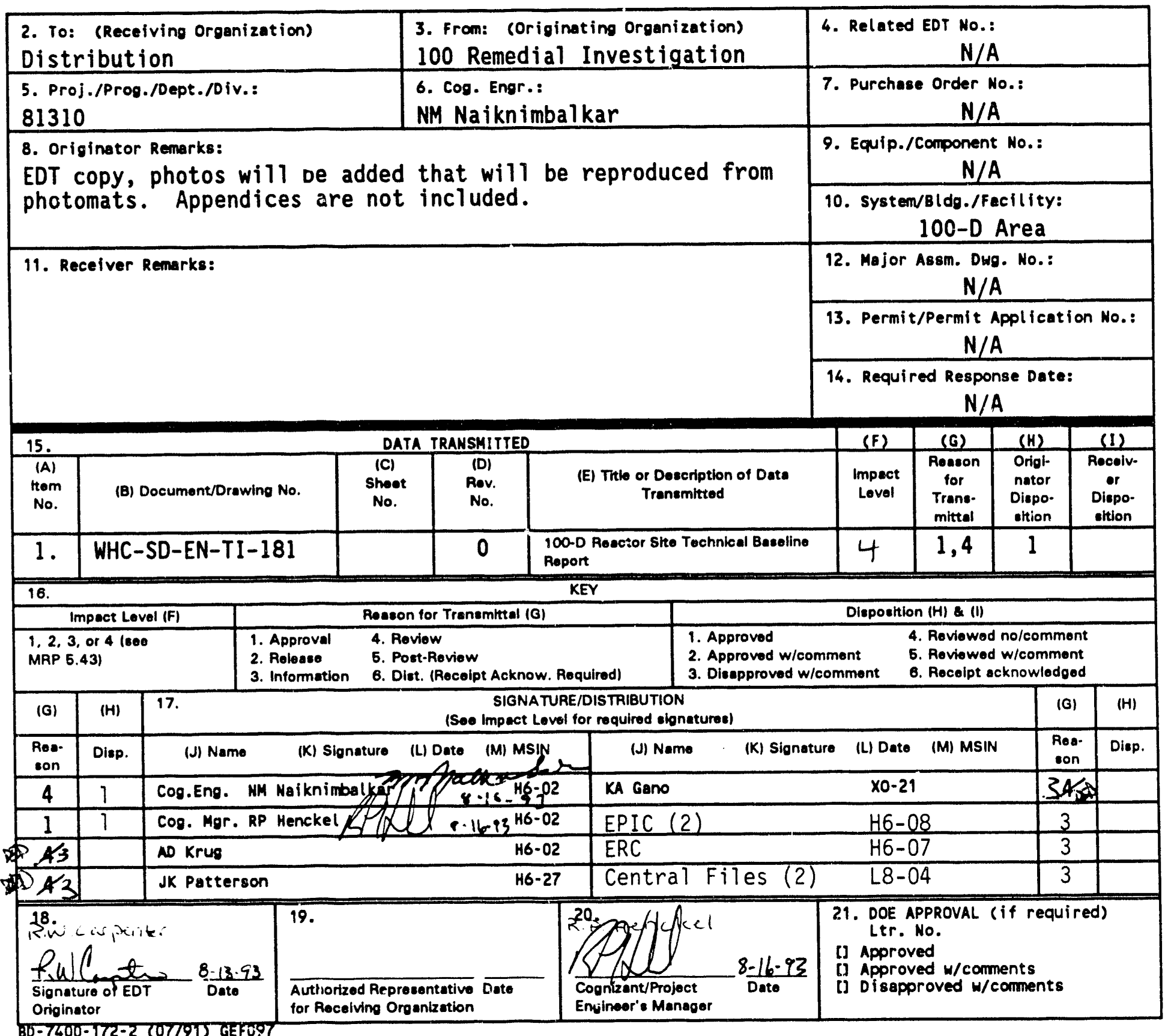




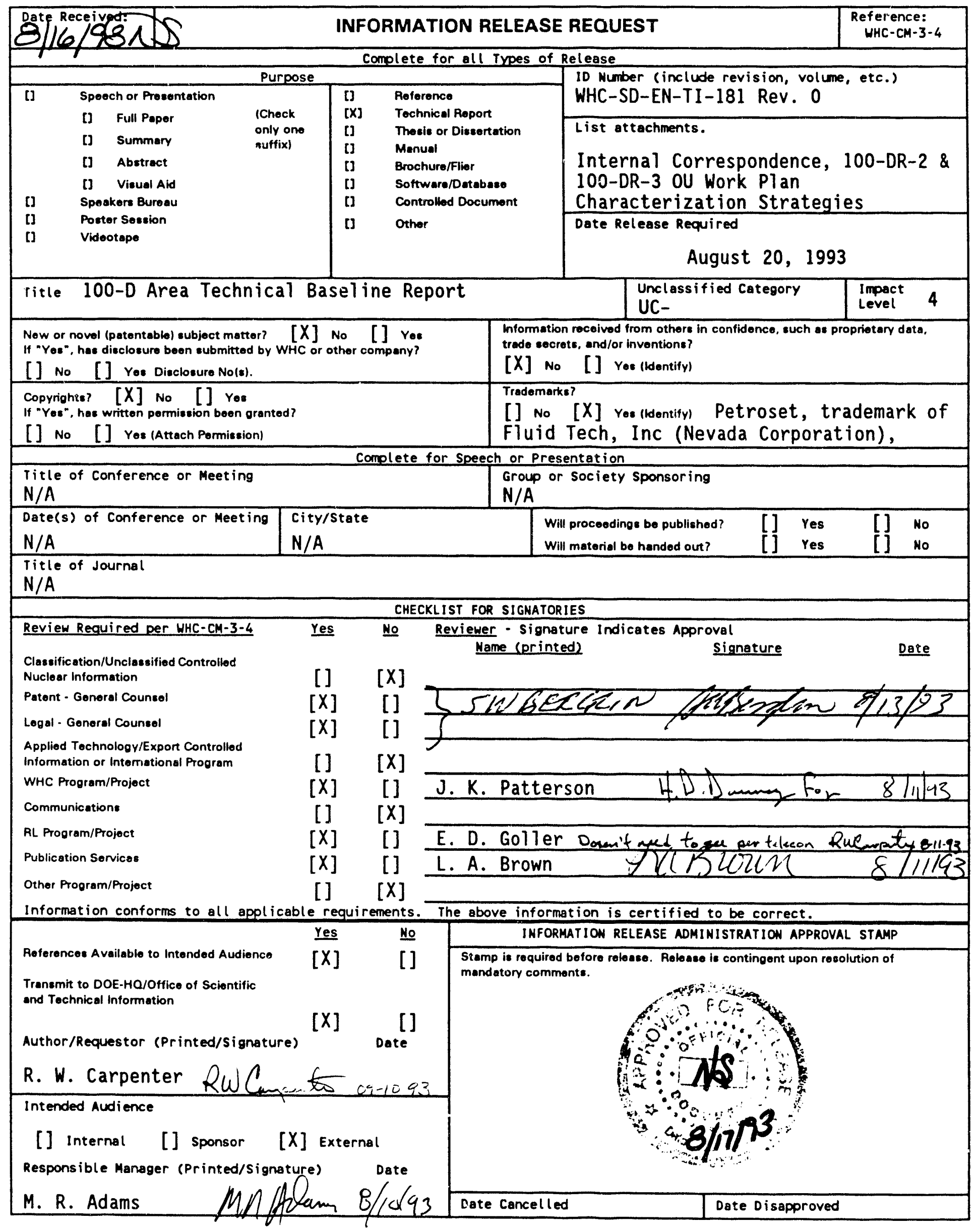


3. Number WHC-SD-EN-TI-181

4. Rev No.

\section{Key Words}

100-D Area, 100-D Reactor, 100-DR Reactor, 100-DR-1 OU, 100-DR-2 OU, 100-DR-3 OU, solid wastes, liquid wastes, storage basins, septic systems, burial grounds, waste sites

$$
\text { A. }
$$

6. Author

Name: R. W. Carpenter

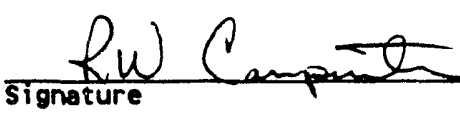

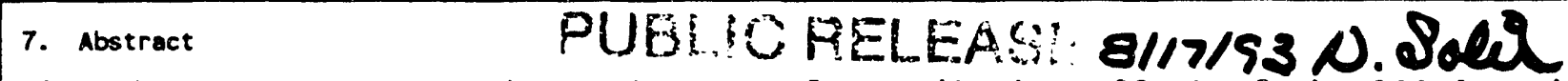

This document supports the environmental remediation effort of the 100 Area by providing remediation planners with key data that characterize the 100-D and 100-DR Reactor sites. It provides operational histories of 100-D, 100-DR, and each of their associated liquid and solid waste sites.

Carpenter, RW, 1993, 100-D Area Technical Basel ine Report, WHC-SD-EN-TI-181, Westinghouse Hanford Company, Richland, Washington.

8. PNRPOSE AND USE OF DOCUMENT - This document uas prepapochor use wi in the U.S. Department of Energy and its colracyers. It is to be sed only to perform, direct, or intes te work under U.S. Dartment of Engy contracts. This docun'st is not approved for public release yit reviewed.

PATENT STATO This document copk sina it $\mathrm{s}$ transmitted in advance of paint clearance, is made tyailable $h$ confidence solely for use $n$ peformence of work under contracts with the U.S. Depe ment of nergy. This document not to be publi ished nor its copents otherwis disseminated or usut purposes other than specj ied above before mtent approval ior sucm release or use has ber secured, upon request, from the atent Counsel, U.S. Department Energy field office, Richland, $y$.

DISCLAIMER - This report was prepared as an account of work sponsored by an agency of the United States Government. Neither the United States Government nor any agency thereof, nor any of their employees, nor any of their contractors, subcontractors or their employees, makes any warranty, express or implied, or assumes any legal liability or responsibility for the accuracy, completeness, or any third party's use or the results of such use of any information, apparatus, product, or process disclosed, or represents that its use would not infringe privately owned rights. Reference herein to any specific commercial product, process, or service by trade name, trademark, manufacturer, or otherwise, does not necessarily constitute or imply its endorsement, recormendation, or favoring by the United States Government or any agency thereof or its contractors or subcontractors. The views and opinions of authors expressed herein do not necessarily state or reflect those of the United States Government or any agency thereof.

10. RELEASE STAMP

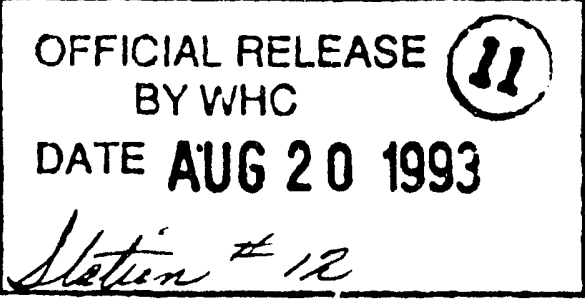


WHC-SD-EN-TI-181, Rev. 0

\section{CONTENTS}

1.0 INTRODUCTION . . . . . . . . . . . . . . . . . . 1-.

2.0 BACKGROUND . . . . . . . . . . . . . . . . . . . . 2-1

2.1 GENERAL DESCRIPTION OF 100-D/DR FACILITIES . . . . . . 2-1

2.2 AREA HISTORY .................... 2-2

2.3 REACTOR SITE HISTORY . . . . . . . . . . . . . 2-2

2.3.1 Reactor Process Liquid Wastes and Cooling Water

Effluent................ 2-5

2.3.2 Fuel Storage Basin Water. ............ 2-9

2.3.3 Decontamination Solutions . . . . . . . . . 2-9

2.3.4 Radioactive Sludges and Solid Wastes . . . . . . . 2-11

2.3.5 Reactor Ventilation System and Inert Gas System

Wastes............... 2-12

2.4 SANITARY LIQUID WASTES . . . . . . . . . . . . . . . . 2-14

2.5 NONRADIOACTIVE LIQUID WASTES .............. . 2-14

2.6 NONRADIOACTIVE SOLID WASTES ............... . 2-16

3.0 SOIL AND VEGETATION SAMPLING ..................

4.0 100-DR-1 OPERABLE UNIT . . • . • . • . . . . . . . . . 4-1

4.1 116-D-1A (105-D STORAGE BASIN TRENCH \#1) ......... . 4-2

4.2 116-D-1B (105-D STORAGE BASIN TRENCH \#2).......... $4-4$

4.3 116-D-2 (105-D PLUTO CRIB) . . . . . . . . . . . . . . . 4-7

4.4 116-D-3 FRENCH DRAIN (108-D CRIB \#1) . . . . . . . . . . . 4-9

4.5 116-D-4 FRENCH DRAIN (108-D Crib \#2) . . . . . . . . . . 4-11

4.6 116-D-5 (1904-D OUTFALL STRUCTURE) . . . . . . . . . 4-12

4.7 116-D-6 (105-D CUSHION CORRIDOR FRENCH DRAIN) $. . . . .44-12$

4.8 116-D-7 (107-D RETENTION BASIN) . . . . . . . . . . 4-16

4.9 116-D-9 (117-D SEAL PIT CRIB) . . . . . . . . . . . . 4-18

4.10 116-D-10 (105-D FUEL STORAGE BASIN CLEANOUT PERCOLATION

PIT) . . . . . . . . . . . . . . . . 4-19

4.11 116-DR-1 (107-DR LIQUID WASTE DISPOSAL TRENCH \#1) ... 4-20

4.12 116-DR-2 (107-DR LIQUID WASTE DISPOSAL TRENCH \#2) . . . . . 4-23

4.13 116-DR-5 (1904-DR OUTFALL STRUCTURE) . . . . . . . . 4-23

4.14 116-DR-9 (107-DR RETENTION BASIN) ........... . 4-25

4.15 118-D-6 (105-D REACTOR BUILDING) . . . . . . . . . . 4-29

4.16 120-D-1 (100-D PONDS) . . . . . . . . . . . . . . . 4-30

4.17 120-D-2 (186-D WASTE ACID RESERVOIR) . . . . . . . . . 4-32

4.18 126-D-1 (184-D POWERHOUSE ASH PIT) . . . . . . . . . . 4-34

4.19 126-D-2 (184-D COAL PIY) . . 4-35

$4.20126-D-3$ (D-AREA BRINE AND SALT DILUTION PIT SITE) . . . . 4-38

4.21 128-D-2 (BURN PIT) . . . . . . . . . . . 4-39

4.22 130-D-1 (1716-D GASOLINE STORAGE TANK SITE) . . . . . . . 4-40

4.23 132-D-1 (115-D/DR GAS RECIRCULATING FACILITY SITE) • . . . 4-41

4.24 132-D-2 (117-D FILTER BUILDING SITE) . . . . . . . . 4-45

4.25 132-D-3 (1608-D WASTE WATER PUMPING STATION SITE) . . . . . 4-45

4.26 132-D-4 (116-D REACTOR EXHAUST STACK) . . . . . . . . . . 4-47

4.27 628-3 (BURN PIT) . . . . . . . . . . . . . . . . . . . . 4-48

4.28 1607-D SEPTIC TANKS AND ASSOCIATED DRAIN FIELDS .. . . . . . 4-49

4.29 UNDOCUMENTED LIQUID WASTE SITE, TRENCH NEAR 107-D . . . . . . 4-53 
CONTENTS (cont.)

4.30 UNDOCUMENTED SOLID WASTE SITE NEAR 103-D . . . . . . . . 4-53

4.31 UNDOCUMENTED SOLID WASTE SITE, BURIED VSR THIMBLE . . . . . . 4-54

4.32 UNDOCUMENTED MINOR CONSTRUCTION SOLID WASTE BURIAL SITES • . 4-54

4.33 UNDOCUMENTED SOLID WASTE BURIAL GROUND, SILICA GEL . . . . . 4-57

4.34 UNDGCUMENTED SOLID WASTE SITE . . . . . . . . . . . . 4-58

4.35 UNDOCUMENTED LIQUID WASTE SITE, 105-DR PROCESS SEWER OUTFALL

SITE . . . . . . . . . . . . . . . . 4-58

4.36 UNDOCUMENTED LIQUID IASTE SITE, UNDERGROUND FUEL STORAGE

TANKS . . . . . . . . . . . . . . . . . . 4-61

4.37 UNDOCUMENTED LIQUID WASTE SITE, CONTAMINATED STORM DRAIN * . 4-61

4.38 UNDOCUMENTED SOLID WASTE SITE, LEAD SHEETING ........ 4-61

4.39 UNDOCUMENTED LIQUID WASTE SITE, OIL SOAKED SOIL . . . . . . . 4-62

4.40 UNDOCUMENTED LIQUID WASTE SITE, STORM DRAIN OUTFALL . . . . . 4-62

4.41 100-DR-1 AREA SITE DESCRIPTIONS AND BUILDING DIRECTORY . . . 4-63

5.0 100-DR-2 OPERABLE UNIT . . . . . . . . . . . . . . . 5-1

5.1 116-D-8 (100-D CASK STORAGE PAD) . . . . . . . . . . . 5-1

$5.2116-D R-3$ (105-DR STORAGE BASIN TRENCH) .......... . 5-3

5.3 116-DR-4 (105-DR PLUTO CRIB) . . . . . . . . . . . . . 5-5

5.4 116-DR-6 (1608-DR LIQUID DISPOSAL TRENCH) $\ldots . . . . . . \quad$. $5-8$

5.5 116-DR-7 (105-DR INKWELL CRIB) ............ 5-8

5.6 116-DR-8 (117-DR SEAL PIT CRIB) . . . . . . . . . . . . . . 5-9

5.7 118-D-5 (BALL 3X BURIAL GROUND) . . . . . . . . . . . . . . 5-10

5.8 118-DR-2 (105-DR REACTOR BUILDING) .......... . . 5-12

5.9 122-DR-1 (105-DR SODIUM FIRE FACILITY) . . . . . . . . . . 5-16

5.10 126-DR-1 (190-DR CLEARWELL TANK PIT) . . . . . . . . 5-18

5.11 132-DR-1 (1608-DR WASTE WATER PUMPING STATION SITE) . . . 5-20

5.12 132-DR-2 (116-DR REACTOR EXHAUST STACK) ....... . 5-22

5.13 1607-D SEPTIC TANKS AND ASSOCIATED DRAIN FIELDS . . . . . . . . 5-22

5.14 UNDOCUMENTED WASTE SITE, TEMPORARY GARAGE AND GASOLINE

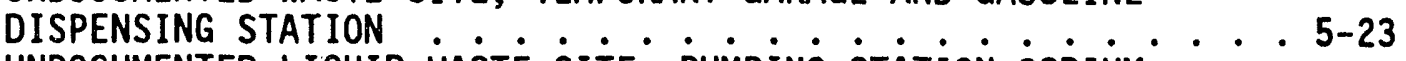

5.15 UNDOCUMENTED LIQUID WASTE SITE, PUMPING STATION SODIUM

DICHROMATE/ACID RAILCAR AND TRUCK UNLOAD STATION AND FRENCH

DRAIN • • • • . . • . • • • • . . . . . . . . 5-23

5.16 100-DR-2 AREA SITE DESCRIPTIONS AND BUILDING DIRECTORY . . 5-24

$6.0100-D R-3$ OPERABLE UNIT . . . . . . 6-1

$\begin{array}{ll}6.1 & 116-D R-10 \\ \text { PERCOLATION POND) (105-DR FUEL STORAGE BASIN CLEANOUT } \\ 6 . \ldots . . . & 6-1\end{array}$

$6.2118-D$-1 (100-D BURIAL GROUND NUMBER 1).......... $6-2$

6.3 118-D-2 (100-D BURIAL GROUND NUMBER 2) .......... $6-3$

6.4 118-D-3 (100-D BURIAL GROUND NUMBER 3) . . . ..... . . 6-6

6.5 118-D-4 (CONSTRUCTION BURIAL GROUND) . . . . . . . . . . . 6-8

6.6 118-DR-1 (105-DR GAS LOOP BURIAL GROUND) . . . . . . . . . . 6-9

6.7 128-D-1 (100 D/DR BURNING PIT) . . . . . . . . . . . . . . 6-10

6.8 1607-D SEPTIC TANKS AND ASSOCIATED DRAIN FIELDS . . . . . . . 6-10

6.9 UNDOCUMENTED SOLID WASTE BURIAL SITE USED BY MINOR

CONSTRUCTION . . . . . . . . . . . 6-15

6.10 UNDOCUMENTED SOLID WASTE SITES ............

6.11 UNDOCUMENTED SOLID WASTE SITE, BURN PIT .......... . 6-16

6.12 100-DR-3 AREA SITE DESCRIPTIONS AND BUILDING DIRECTORY . . 6-17 
WHC-SD-EN-TI-181, Rev. 0

CONTENTS (cont.)

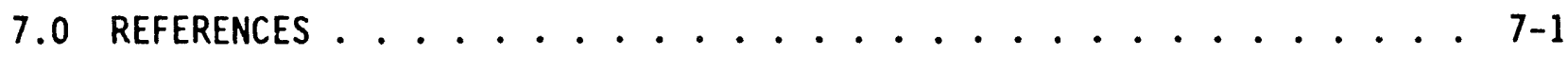

8.0 BIBLIOGRAPHY ...................... . . . . . . . . .

9.0 HANFORD DRAWINGS REFERENCED IN TEXT . . . . . . . . . . . . . . . 9-1

APPENDIXES:

APPENDIX A Table of Photographs Used . . . . . . . . . . . . . . A A

APPENDIX B Maps ........................... B-1

APPENDIX C Radionuclide Inventory . . . . . . . . . . . . . . . C-I

APPENDIX D Internal Correspondence . . . . . . . . . . . . . . . . . . . D-1

APPENDIX E 100-DR-2 Operable Unit Work Plan Characterization

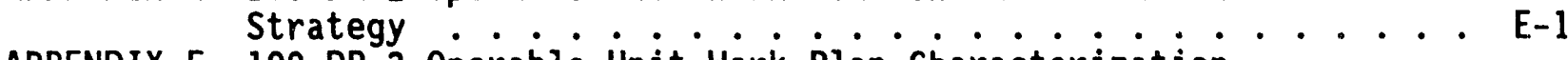

APPENDIX F 100-DR-3 Operable Unit Work Plan Characterization

Strategy .................. F-1 
WHC-SD-EN-TI-181, Rev. 0

FIGURES:

2-1 100-D Area from the Southeast, 1962 . . . . . . . . . . 2-1

2-2 100-D Area from the Southeast, pre-1948 . . . . . . . . . 2-3

2-3 100-D Area from the Southwest, 1950 . . . . . . . . . . . 2-4

2-4 Typical Water Treatnient System . . . . . . . . . . . . 2-5

2-5 100-D Area from the North, 1956 . . . . . . . . . . . . 2-7

2-6 1904-D Outfall Structure, 1944 . . . . . . . . . . . . 2-8

2-7 105-D Fuel Storage Basin ............... . . 2-10

2-8 105-D Fuel Storage Basin During Cleanout . . . . . . . . . 2-10

2-9 Typical Confinement Facility Layout . . . . . . . . . . . 2-13

4-1 Project CG-558, 1955 . . . . . . . . . . . . . . . 4-3

4-2 116-D-1A, 1993 ..................... 4-4

4-3 116-D-1B, 1993 . . . . . . . . . . . . . . . . 4-6

4-4 Possible Location of the 116-D-2 Pluto Crib, 1993 . . . . . . . . 4-8

4-5 Possible Location of Pluto Crib \#2 . . . . . . . . . . . . 4-8

4-6 Possible Location of the Pluto Crib \#3 . . . . . . . . . . . 4-9

4-7 108-D French Drain \#1 ................... . 4-10

4-8 108-D French Drain \#2 .................... . 4-11

4-9 1904-D Outfall, 1944 . . . . . . . . . . . . . . 4-13

4-10 116-D-5, 1904-D Outfall Structure, 1992 . . . . . . . . . . 4-13

4-11 116-D-5, 1904-D Outfall Flume, 1993 ............ 4-14

4-12 105-D Cushion Corridor French Drain ............. . 4-15

4-13 100-D Area, 1944, Retention Basins ............. . 4-16

4-14 116-D-7, 107-D Retention Basin, 1993 . . . . . . . . . 4-18

4-15 116-D-9, 117-D Seal Pit Crib, 1993 . . . . . . . . . . 4-19

4-16 100-D Fuel Storage Basin Cleanout Ponds . . . . . . . . . . . . 4-21

4-17 116-DR-1 and 116-DR-2, 107-DR Liquid Disposal Trenches . . . . . 4-22 
4-18 116-DR-5, 1904-DR Outfal1, 1956................. 4-24

4-19 116-DR-5, 1904-DR Outfal1, 1993 . . . . . . . . . . . 4-25

4-20 116-DR-5, 1904-DR Outfall Flume, 1993 ............ 4-26

4-21 107-DR Retention Basin Construction . . . . . . . . . . 4-27

4-22 107-DR Retention Basin Construction ............. 4-27

4-23 116-DR-9, 107-DR Retention Basin, 1993 ........... 4-29

4-24 105-D . . . . . . . . . . . . . . . . . . . 4-30

4-25 120-D-1, 100-D Area Ponds, 1993 . . . . . . . . . . . . . . . . . . 22

4-26 186-D Waste Acid Basin . . . . . . . . . . . . . . 4-33

4-27 100-D Area Ash Disposal Basin Orphan 55-gal Drum . . . . . . . 4-34

4-28 100-D Area, Coal Pit . . . . . . . . . . . . . . 4-35

4-29 184-D Coal Pit, 1969 ...................... 4-37

4-30 184-D Coal Pit Today . . . . . . . . . . . . . . . 4-37

4-31 Salt and Brine Pit . . . . . . . . . . . . . . . 4-38

4-32 Subsidence Near Salt and Brine Pif ............. . 4-39

4-33 128-D-2, Burn Pit, 1993 ................ 4-40

4-34 100-D Gasoline Tank Site . . . . . . . . . . . . . . 4-4,2

4-35 Septic Tank Surrounded by White Fence, 1953 . . . . . . . . . 4-43

4-36 115-D/DR Gas Recirculation Facility . . . . . . . . . . . . 4-44

4-37 117-D Confinement Air Filter Facility . . . . . . . . . . . . 4-46

4-38 1608-D Facility . . . . . . . . . . . . . . . . . 4-47

4-39 628-3 Suspect Site ..................... . 4-48

4-40 East of the 100-D Area Near the 628-3 Farm Dump . . . . . . . . . 4-49

4-41 1607-D2, Septic Tank, 1993 ................ 4-50

4-42 1607-D2 Septic Drain Field, 1993 ............... 4-51

4-43 Septic System at 181-D .................... . 4-51

4-44 Suspect Septic System Manhole . . . . . . . . . . . . 4-52

4-45 Suspect Solid Waste Burial Site, 1993 . . . . . . . . . . . 4-53 
4-46 100-D Area Waste Sites . . . . . . . . . . . 4-55

4-47 Hanford Drawing H-1-4046 . . . . . . . . . . 4-56

4-48 VSR Burial Ground . . . . . . . . . . . . . . . . 4-57

4-49 Undocumented Solid Waste Site Outside Burial Ground Markers . . . 4-58

4-50 Suspect Solid Waste Site East of the 100-D Area . . . . . . . 4-59

4-51 Suspect Solid Waste Site East of the 100-D Area . . . . . . . 4-59

4-52 1907-DR Outfall Before Demolition . . . . . . . . . 4-60

4-53 1907-DR Outfall Today . . . . . . . . . . . 4-60

4-54 Suspect Liquid Waste Site, Storm Drain Near 1904 Outfalls . . . . 4-61

4-55 Lead Sheet Cover on Concrete Pad South of the 186-D Building

Site ...................... 4-62

4-56 0il-contaminated Soil East of 190-D. . . . . . . . 4-63

4-57 Subsidence Near the 189-D Storage Pad. . . . . . . . . . 4-65

4-58 Detail of Figure 4-57 . . . . . . . . . . . . 4-65

4-59 Filter Backwash Trench . . . . . . . . . . . . 4-67

4-60 Flume Upstream of the 181-D Pumphouse . . . . . . . . . 4-68

4-61 Pipe in the Flume Upstream of the 181-D Pumphouse . . . . . . 4-68

4-62 Acid Tank Cradles and Drain Trench Near 192-D . . . . . . . . 4-70

5-1 Cask Pad, Suspect French Drain Addition, 1949 . . . . . . . . 5-2

5-2 100-D Cask Pad ................. 5-3

5-3 105-DR Fuel Storage Basin Trench ........... 5-5

5-4 105-DR PTuto crib ................ 5-7

5-5 1608-DR Effluent Trench . . . . . . . . . . . . 5-9

5-6 105-DR Ink Well Crib (Tank) . . . . . . . . . 5-10

5-7 117-DR Crib (116-DR-8) . . . . . . . . . 5-11

5-8 VSR Thimble Burial Ground South of 105-DR . . . . . . . . . 5-12

5-9 105-DR Fuel Storage Basin Leakage . . . . . . . . . . 5-14

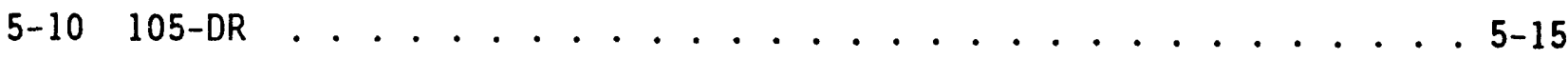


5-11 French Drain Near the Sodium Fire Facility Water Filter . . . . . 5-16

5-12 Sodium Fire Facilities . . . . . . . . . . . . . . 5-17

5-13 190-DR Tankwell Pit Burial Ground . . . . . . . . . . . . 5-18

5-14 Asbestos Contamination Area in the . . . . . . . . . . . 5-19

5-15 1608-DR Facility Site . . . . . . . . . . . . . . 5-20

5-16 151-D Septic Tank an', Drain Field . . . . . . . . . . . . 5-22

5-17 Sodium Dichromate Pumping Station . . . . . . . . . . . . 5-24

6-1 105-DR Fuel Storage Basin Cleanout Pond . . . . . . . . . . 6-3

6-2 100-D Area Burial Ground Number One . . . . . . . . . . . . . 6-4

6-3 100-D Area Burial Ground Number Two . . . . . . . . . . . . . 6-5

6-4 Suspect Liquid Waste Site . . . . . . . . . . . . . . . 6-7

6-5 118-D-3 Burial Ground . . . . . . . . . . . . . . . 6-8

6-6 118-D-4 Burial Ground . . . . . . . . . . . . . . . . . 6-9

6-7 100-DR Gas Loop Burial Ground . . . . . . . . . . . . . . 6-10

6-8 Suspect Location of the 128-D-1 Burn Pit . . . . . . . . . . 6-11

6-9 100-D Area Patrol and Fire Station . . . . . . . . . . . . 6-13

6-10 Undocumented Septic Tank (IMHOFF Tank) . . . . . . . . . 6-13

6-11 Undocumented Septic Drain Field . . . . . . . . . . . . . 6-14

6-12 Undocumented Septic Tank and Drain Field . . . . . . . . . 6-14

6-13 01d Barrow Pit Burial Ground. . . . . . . . . . . . . . 6-15

6-14 Present Barrow Pit and Burial Ground . . . . . . . . . . . . 6-16

6-15 Undocumented Burn Pit, 1948 . . . . . . . . . . . . . 6-17

6-16 100-D Area Air Monitor Station (Historic Landmark) . . . . . . 6-18 
WHC-SD-EN-TI-181, Rev. 0

\section{TABLES:}

3-1 Average Radionuclide Concentrations ( $\mathrm{pCi} / \mathrm{g}$ ) Detected in the 100-D Area Surface Soil Samples from 1981 to 1991 .......... . 3-1

3-2 Average Radionuclide Concentrations ( $\mathrm{pCi} / \mathrm{g}$ ) Detected in the 100-D Area Vegetation Samples from 1981 to 1991 . . . . . . . . . 3-2

4-1 Hazard Ranking System Migration Scores . . . . . . . . . . . 4-1

4-2 116-D-1A Radionuclide Irventory . . . . . . . . . . . 4-2

4-3 116-D-1A Radionuclide Inventory . . . . . . . . . . . . 4-3

4-4 116-D-1B Radionuclide Inventory . . . . . . . . . . . . . 4-5

4-5 116-D-1B Radionuclide Inventory . . . . . . . . . . . . . 4-5

4-6 HEHF Soil Sampling Results ................... 4-41

4-7 Septic Tank Systems . . . . . . . . . . . . . . . . 4-50

4-8 Potentially Contaminated Facilities . . . . . . . . . . 4-64

4-9 Low Potential for Contamination Facilities . . . . . . . . . 4-70

5-1 Hazard Ranking System Migration Score . . . . . . . . . . . 5-1

5-2 116-DR-3 Radionuclide Inventory . . . . . . . . . . . . . 5-4

5-3 116-DR-3 Radionuclide Inventory . . . . . . . . . . . . . 5-4

5-4 116-DR-4 Radionuclide Inventory . . . . . . . . . . . . . 5-6

5-5 116-DR-4 Radionuclide Inventory . . . . . . . . . . . . . 5-7

5-6 Survey Results . . . . . . . . . . . . . . . . . . 5-13

5-7 Septic Tank Systems . . . . . . . . . . . . . . . . 5-21

5-8 Potentially Contaminated Facilities . . . . . . . . . . . . 5-24

5-9 Low Potential for Contamination Facilities . . . . . . . . . . 5-25

6-1 Hazard Ranking System Migration Score . . . . . . . . . . . 6-1

6-2 Metallic Wastes . . . . . . . . . . . . . . . . . 6-5

6-3 Metallic Wastes .................... . 6-6

6-4 Septic Systems . . . . . . . . . . . . . . . . . 6-12

6-5 Facilities...................... . 6-18 


\section{$\therefore$ INTRODUETION}

This document is prepared in support of the 100 Area Environmental Restoration activity at the U.S. Department of Energy's Hanford Site near Richland, Washington. It provides a technical baseline of waste sites located at the 100-D Area. The report is based on an environmental investigation undertaken by the Westinghouse Hanford Company (WHC) History Office in support of the Environmental Restoration Engineering Function and on review and evaluation of numerous Hanford Site current and historical reports, drawings, and photographs, supplemented by site inspections and employee interviews. No intrusive field investigation or sampling was conducted. All Hanford coordinate locations are approximate locations taken from several different maps and drawings of the 100-D Area. Every effort was made to derive coordinate locations for the center of each facility or waste site, except where noted, using standard measuring devices. Units of measure are shown as they appear in reference documents.

The 100-D Area is made up of three operable units: 100-DR-1, 100-DR-2, and 100-DR-3. All three are addressed in this report. These operable units include liquid and solid waste disposal sites in the vicinity of, and related to, the 100-D and 100-DR Reactors. A fourth operable unit, 100-HR-3, is concerned with groundwater and is not addressed here. This report describes waste sites which include cribs, trenches, pits, french drains, retention basins, solid waste burial grounds, septic tanks, and drain fields. Each waste site is described separately and photographs are provided where available. A complete list of photographs can be found in Appendix $A$.

A comprehensive environmental summary is not provided here but may be found in Hanford Site National Environmental Policy Act Characterization (Cushing 1988), which describes the geology and soils, meteorology, hydrology, land use, population, and air quality of the area. 


\subsection{BACKGROUND}

\subsection{GENERAL DESCRIPTION OF 100-D/DR FACILITIES}

Nine water-cooled, graphite moderated, plutonium production reactors were constructed by the U.S. government along the Columbia River at the Hanford Site between 1943 and 1963. A11 nine are owned by the U.S. government and are managed by the U.S. Department of Energy (DOE). The reactors are retired from service and have been declared surplus by DOE; all except $\mathrm{N}$-Reactor are available for decommissioning at this time (DOE 1989). The 100-D and 100-DR Reactors are two of these nine (Figure 2-1).

Figure 2-1. 100-D Area from the Southeast, 1962.

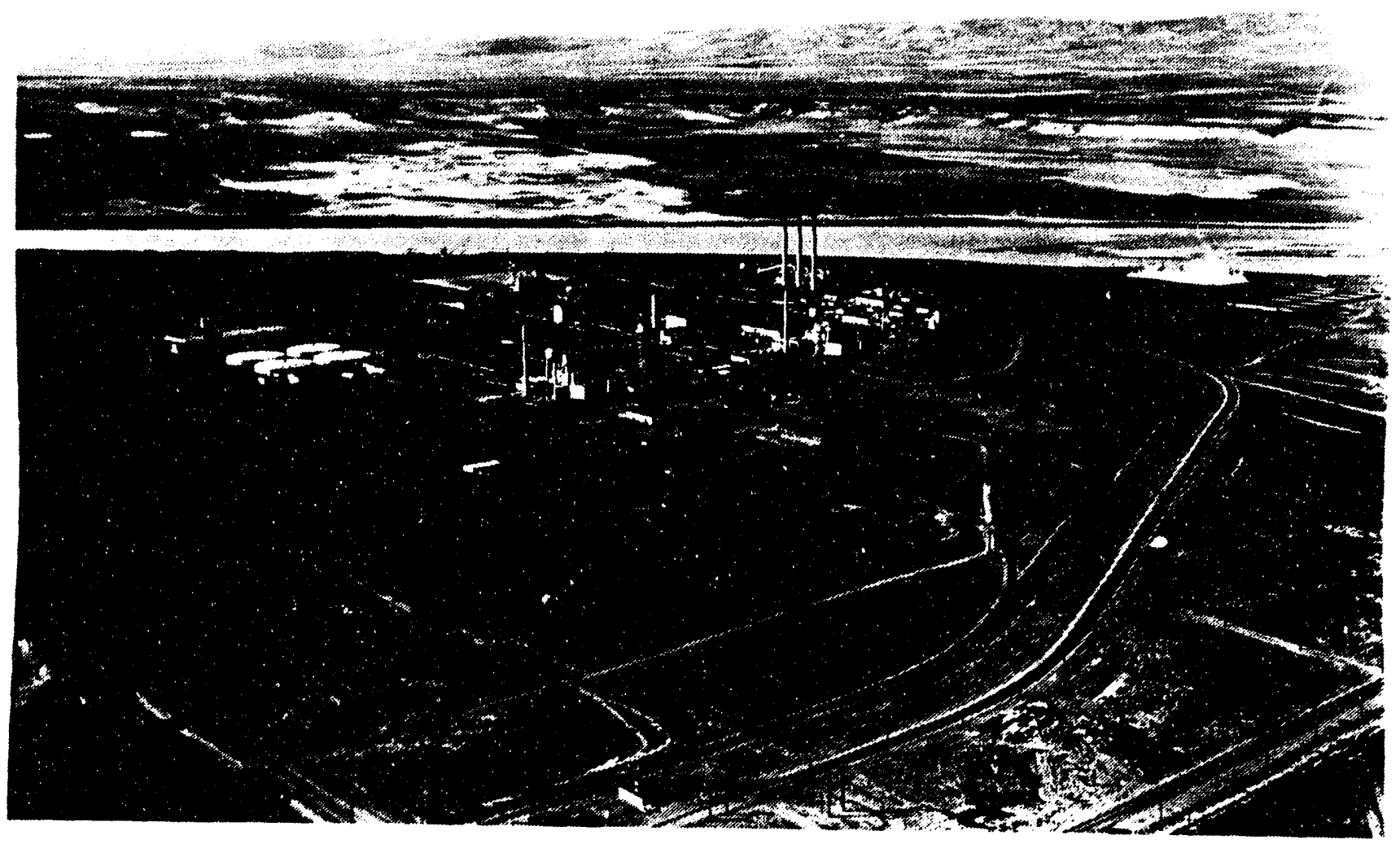


WHC-SD-EN-TI-181, Rev. 0

\subsection{AREA HISTORY}

Anciently, the area of 100-D adjacent to the Columbia River was a favorite hunting and fishing ground for Native Americans. Six prehistoric sites have been identified by Pacific Northwest Laboratories (PNL) within or near the 100-D Area. Three of these are cairns (a conical heap of stones built as a monument or landmark), identified by PNL as sites $45 B N 44$ ?, $45 B N 443$, and 45BN444. They are located west of the 100-D Area outside the operable unit boundaries. A fourth site, 45BN459, contains spalled cobbles and fire cracked rock. A hopper mortar base was noted in the downstream portion of the $45 \mathrm{BN} 459$ site, directiy north of the 182-D reservoir on the river bank (an area frequently washed by sprin's floods). Site 45BN439, near the northeastern edge of the 10C-DR-1 Operable Unit, contains mussel shell scatters, stone tools, cryptocrystali ine silicate cores, and fire cracked rock. Two roads traverse the site but a large part of it appears to be intact. A final site, 45BN416, contains fire cracked rock, debitage, small cobble cairns, and mussel shell fragments. This site is located on the small island next to 100-D (Chatters et al 1992). This mid-channel island may be the one called Watklimpt by the Wanapum Indians (Cushing 1991).

The area included in and immediately adjacent to the 100-DR-1, 100-DR-2, and 100-DR-3 Operable Units was used for livestock grazing prior to its acquisition by the U.S. Army in January 1943. Irrigated orchards and homesteads were located nearby to the northeast, but none are known to have been located within the 100-D Area boundaries, although pre-1943 wire wrapped wooden irrigation pipe and support posts are visible along the river bank north of the retention basins.

Most 100-D Area facilities have been deactivated. Parts of the water treatment facilities remain active as a backup system to the Hanford export water supply system. The 151-D Electrical Distribution Substation al so remains active and provides backup to the 100-N Area.

Boaters and sports fisherman frequent the Columbia River adjacent to the site but are legally prohibited from trespassing. The island north of the 100-D Area is also posted against trespassing.

\subsection{REACTOR SITE HISTORY}

Construction of the 100-D Reactor began in November 1943. It was the second of three original Hanford reactors built during, and in support of, World War II. Its mission was to generate plutonium for explosive devices to be used in the European and/or Pacific Theaters. European victory in May 1945 had little effect on the urgency to develop nuclear weapons which, it was hoped, would bring a speedy end to the war in the Pacific.

The construction of 100-D was completed in December 1944. initial fuel loading was begun on December 5 and the reactor went critical on the seventeenth. Construction, from ground breaking to initial operation, took only 13 months (Figure 2-2). 
Figure 2-2. 100-D Area from the Southeast, pre-1948.

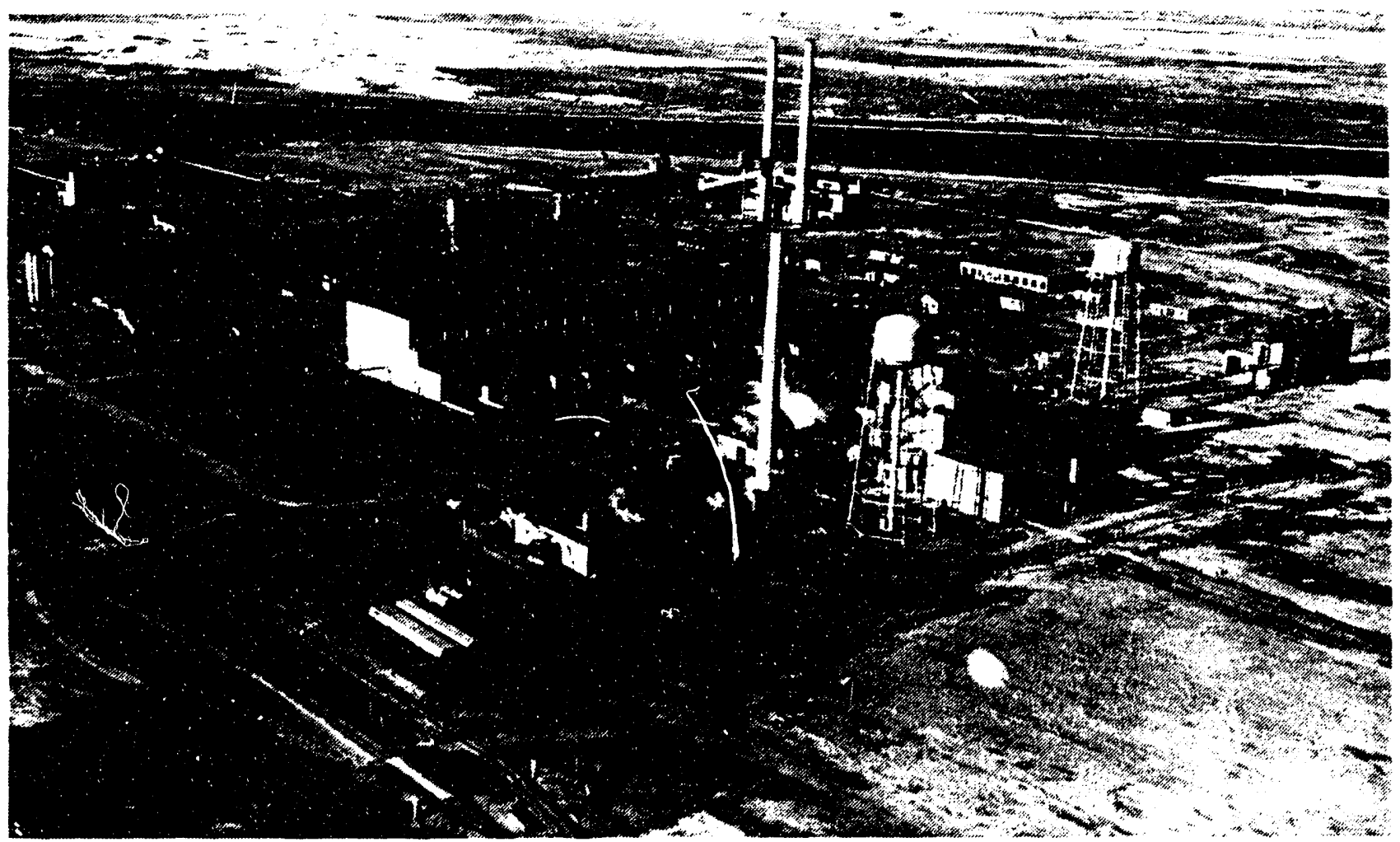

Operating initially at 250 megawatts (thermal) of power, 100-D operating limits were gradually increased until a limit of 2090 megawatts was authorized in 1961. Operations continued at that level until deactivation on June 26 , 1967. The reactor has reinained in deactivated status since that date.

The 100-D Reactor was thought to be nearing the end of its effective operational life in the late 1940's due to growth and distortion of its core graphite. The 100-DR Reactor was constructed as a replacement for 100-D. Its alpha-numeric designator, "100-DR", stands for 100-D Replacement.

100-DR construction began in December 1947 and was completed in March 1949. Initial fuel loading began in September 1950, and initial criticality was reached on October 3, 1950 (Figure 2-3).

It was planned that 100-DR would utilize the 100-D water treatment system, which would become available when 100-D shut down. The water treatment system was modified to supply either reactor, but not both at once. It was subsequently determined that the graphite distortion in 100-D could be controlled; both reactors would operate simultaneously. This required the construction of a separate water treatment plant for 100-DR, including modifications and additions to the river pumphouse, powerhouse, and gas recirculation facilities as well as the water treatment plants. 
Figure 2-3. 100-D Area from the Southwest, 1950.

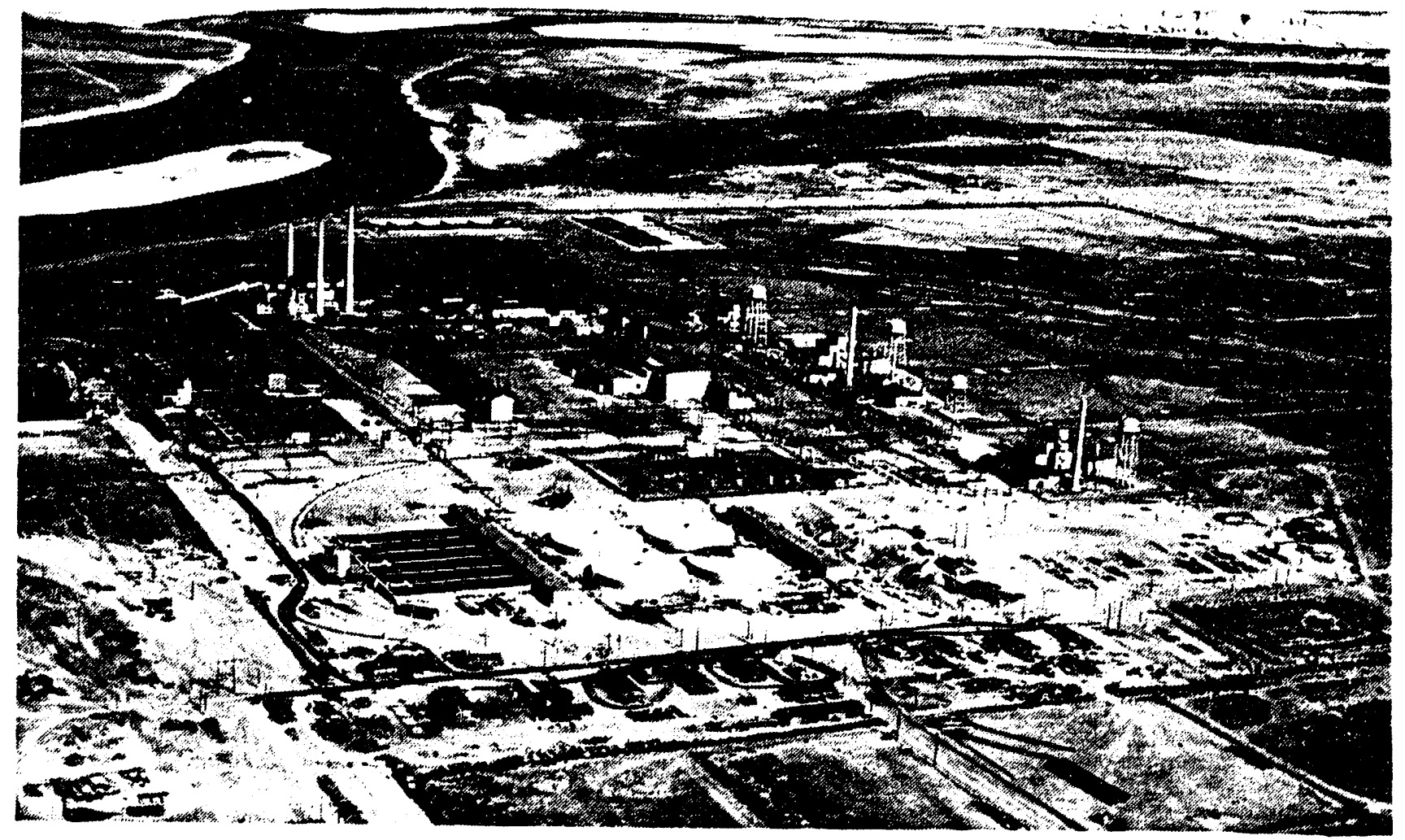

Like $100-D$, the initial operating power limit for 100-DR Reactor was 250 megawatts (thermal). Operating limits were gradually increased until a level of 2090 megawatts was authorized in 1961. Operations continued at that level until deactivation on December 30,1964 . The reactor has remained in deactivated status since that date.

The 100-D Area consisted of several major buildings including the reactor building and numerous structures associated with the treatment and storage of reactor cooling water prior to its use. Most facilities were deactivated with the reactor buildings and have since been decommissioned. A few are still being used for storage.

The liquid effluents generated as a direct result of reactor operations consisted primarily of reactor cooling water, fuel storage basin water, and decontamination solutions. These effiuents are thought to be the most significant wastes in the 100-D Area in terms of potential impact to the groundwater. Tens of millions of liters of this waste were disposed of directly to the soil column both intentionally and as a result of leaks in the cooling water effluent system (DOE 1992a). 


\subsubsection{Reactor Process Liguid Wastes and Cooling Water Effluent}

A continuous supply of high-quality cooling water was essential to reactor operations. It prevented reactor core damage from heat generated by the fission reactions. Many of the 100-D Area facilities were part of this cooling water system. At a daily use rate of 148-204 million gallons, this system generated the largest liquid waste volume in the 100-D area (Figure 2-4).

Figure 2-4. Typical Water Treatment System.

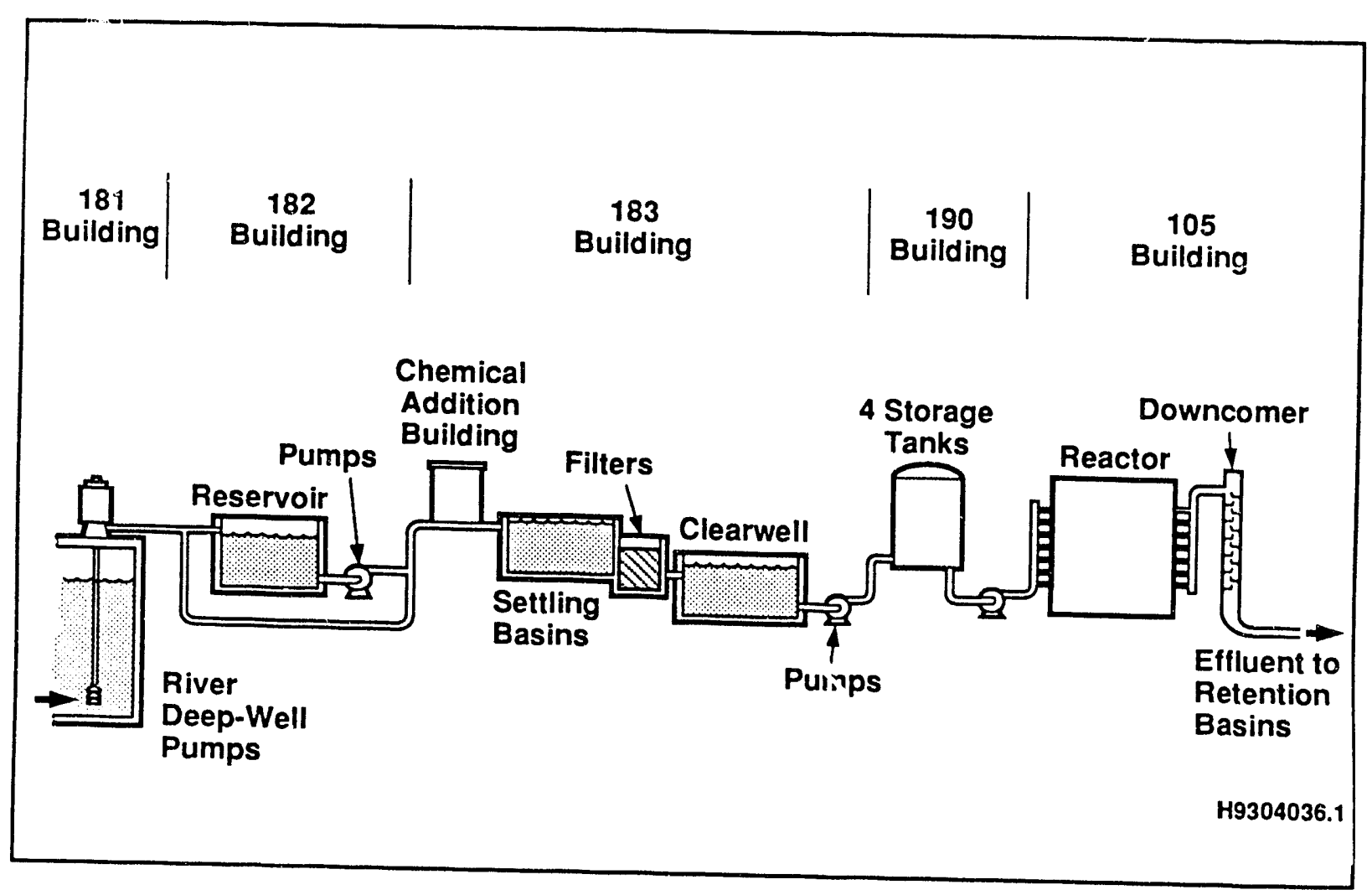

Water obtained from the Columbia River was extensively treated before passing through the reactors. Settling, chemical treatment, filtering, pH management, and refrigeration were utilized to purify and prepare the water. It then circulated in a single pass through the reactor process tubes, cooling The cooling in the thermal shield, and reactor horizontal control rods. fission water exiting the reactors contained radioactive species from the chemical contaminatived activated products from impurities in the water, and the reactors, the charged through outfaling water passed through retention basins and was discharged through outfall structures to the center of the river via large steel
pipes embedded in the river bottom.

While passing through the reactor cores, the water absorbed thermal energy from the nuclear process and became contaminated with radioisotopes. Sources of contamination included the following: 
- Activated elements in the cooling water, caused by the high neutron flux in the reactor cores, created species such as calcium-41, chromium-51, and zinc-65. Most of the species were relatively short-lived and have since decayed to negligible levels. Calcium-4l is a notable exception.

- Activation products from the graphite reactor cores, other reactor components, and fuel cladding were picked up by the cooling water. Significant species included tritium, carbon-14, cobalt-60, nickel-63, and europium-152, -154 , and -155 .

- Fuel element fission products, such as strontium-90 and cesium-137, and transuranics, such as plutonium-239 and -240 , were introduced into the cooling water due to fuel cladding failures.

The concentrations of radionuclides in reactor cooling water were low during normal operations, with an approximated activity of $0.2 \mu \mathrm{Ci} / \mathrm{L}$ (Parker 1947).

Water discharged from the reactors was near boiling. It passed through $100-D$ at a rate of $51,000 \mathrm{gal} / \mathrm{min}$ and through $100-D R$ at $51,800 \mathrm{gal} / \mathrm{min}$ unt il 1957 when the flow was increased to $71,000 \mathrm{gal} / \mathrm{min}$ for both reactors (DeNeal 1965).

The cooling water was transferred from the reactor buildings through effluent lines to the 116-D-7 and 116-DR-9 retention basins for cooling and decay of short-lived radionuclides. It was held in the basins for approximately 2.5 to 4 hours (Healy 1951).

From the retention basins, the water was transferred through large pipes to the 116-D-5 and 116-DR-5 outfail structures and then into pipes that discharged at the bottom center of the Columbia River. Both of these effluent lines pass through the small island north of the 100-D Area. The 116-D-5 outfall line passes through the west end of the island and has several small vent pipes that extend above the surface of the island. These vent pipes often allowed small volumes of effluent water to spill onto the surface of the island and are marked with radiation warning signs. The 116-DR-5 outfall line passes through the approximate center of the island. Both lines discharged on the river bottom just north of the island (Figure 2-5). Overflow from the outfall structures could also discharge directly to the shore of the river through nearby spillways.

Over time, the retention basins and effluent piping developed leaks. cooling water was released to the area around the basins, effluent lines, and river shore at a rate as high as several thousand L/min. (Dorian and Richards 1978). Specific information on leak rates from the retention basins is not available, but contamination detected around the basins indicates that leakage did occur.

The following significant releases have been documented:

- In the spring of 1950, the 116-D-7 basin developed a major leak which became evident on the north side between the basin and the river. Effluent water had drained under the road to an area between the road and the perimeter fence. 
Figure 2-5. 100-D Area from the North, 1956.

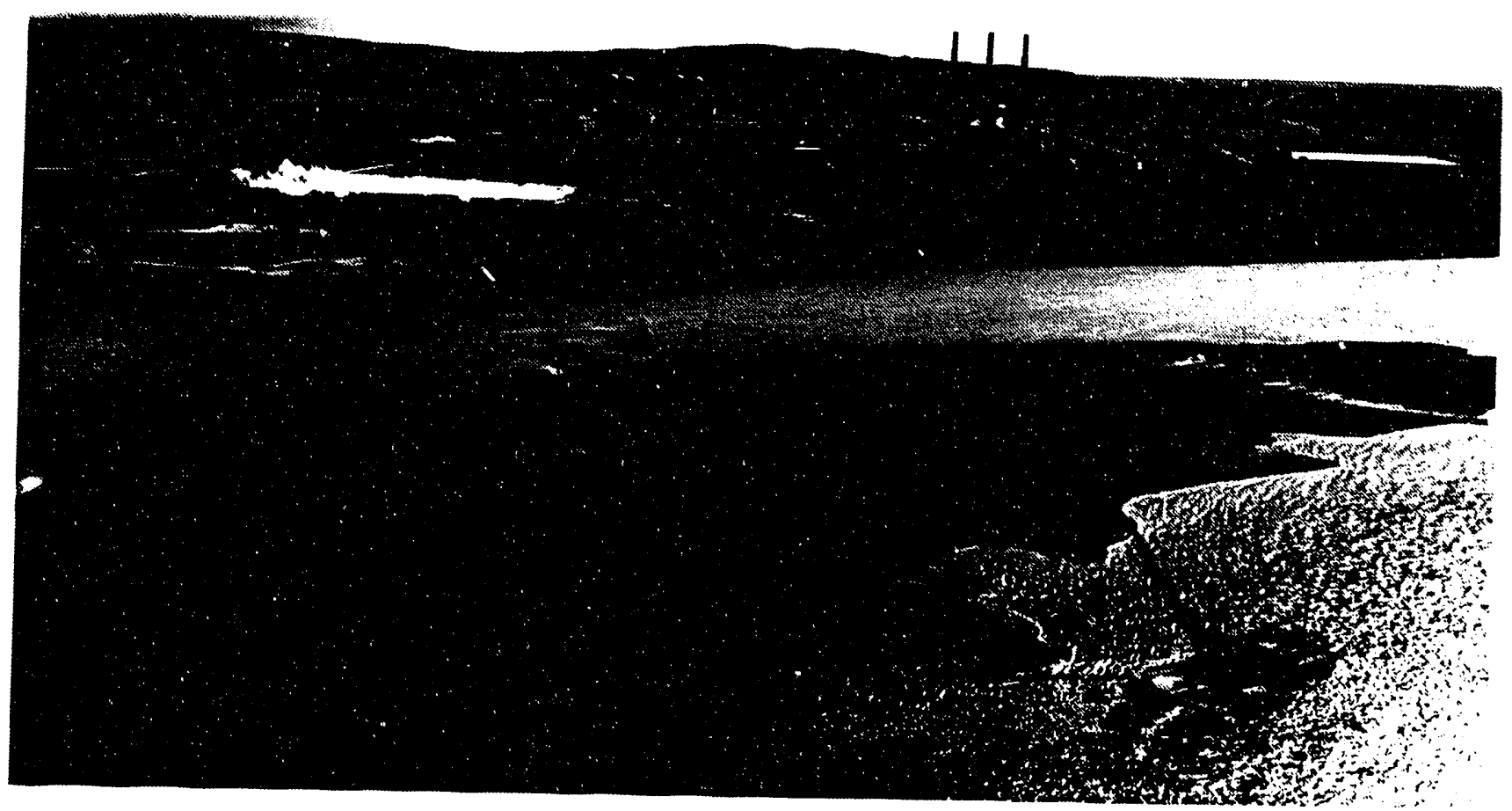

- In 1951, the 116-DR-9 basin experienced excessive leakage at the inlet when the effluent pipes pulled loose from the basin wall. In 1953, a portion of the contaminated soil from this leak was used as fill material around the south anchor blocks to the basin (Rupert 1953).

- In 1951, leaks were reported along the effluent lines about 150 feet southeast of the 116-D-7 retention basin (DOE 1992b). The cooling water contaminated the immediate vicinity of the basins (Rupert 1953).

- In 1967 , a field test was conducted in which the entire effluent volume of the 100-D Reactor was released to the 116-D-1 trench for a period of 4 months (Eliason and Hajek 1967).

Beginning in 1948, fuel-cladding failures occurred while the fuel elements were in the reactor process tubes. Several hundred such failures occurred

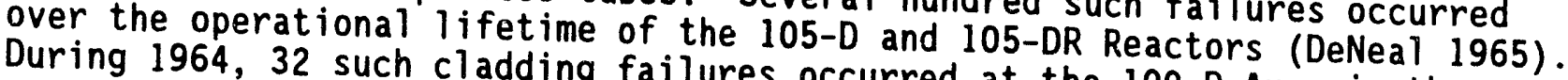
reactor facilities (Newell 1964).

Fuel cladding failures caused the cooling water in the affected process tube to became highly contaminated. Elevated contamination levels were observed in the cooling water exiting the reactor. Several methods were
devised to handle the contaminated cooling water. 
- It is unclear how contaminated conling water was handled following the first few instances of cladding failures. It appears that the water may have been allowed to mix with non-contaminated cooling water and was released to the river.

- Pluto cribs were used to flush the highly contaminated cooling water directly from the affected process tube before it could mix with water from unaffected tubes. The 116-D-2A and the 116-DR-4 pluto cribs were used for this purpose in 1950-1953 and 1950-1956, respectively. After 1956, contaminated cooling water was no longer segregated from the bulk of the cooling water.

- Open emergency dump trenches were used beginning in 1950. The highly contaminated water was segregated and drained to the 116-DR-1 basin trench via a 24-in.-diameter steel pipe that connected the basin outlet with the west end of the trench (PNL 1991). The retention basins were, by construction, divided into two compartments. When a fuel cladding failure occurred, the highly contaminated water was diverted into one of the two compartments. It was then drained to the emergency dump trench. This practice continued on a regular basis until 1954 when increased flows and structural stresses on the basins due to the temperature differences between the full and empty sides necessitated that both sides of the basin be used at the same time. The change to parallel operation in virtually marked the end of "cribbing" rupture effluent (Dorian and Richards 1978) (Figure 2-6).

Figure 2-6. 107-DR Retention Basin, 1948.

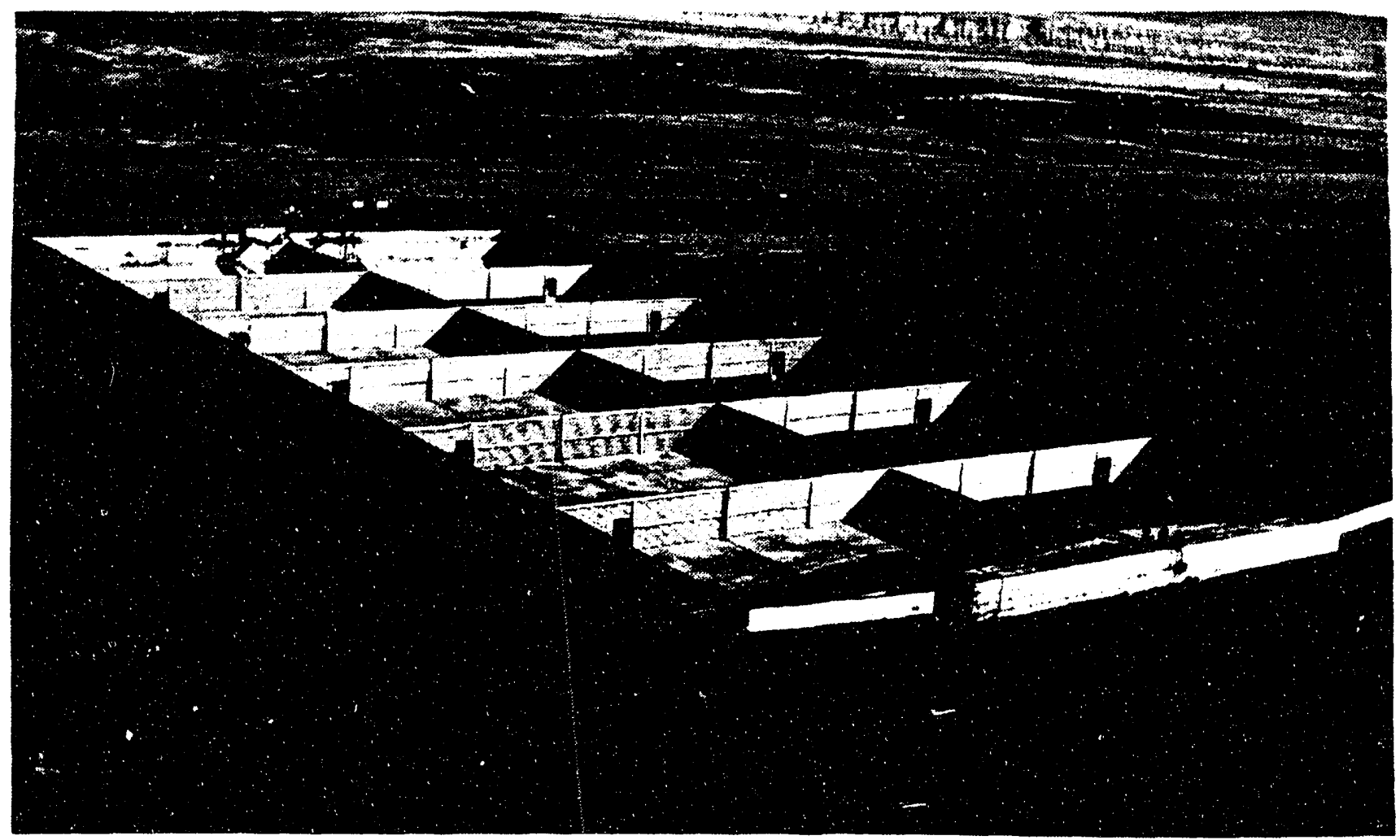


Major reactor maintenance and upgrade outages also generated large volumes of cooling water effluent to be disposed of. When the Ball $3 X$ System was installed in 1953, the reactor effluent was discharged to the 1608-DR 1 iquid disposal trench. 116-D-1A and 116-D-1B trenches (located just east of the 105-D Reactor Building) were also major disposal areas for cooling water effluent during basin maintenance outages between 1947 and 1967 (DOE 1992b).

The 116-DR-1, 116-DR-2, 116-D-2A, and 116-DR-4 trenches and cribs should be considered significant waste units because they consist of direct soil column discharge of 1 iquid wastes with presumably high radioactive contaminant concentrations.

\subsubsection{Fuel Storage Basin Water}

Irradiated reactor fuel elements were stored at the bottom of a large water filled storage basin pending their shipment to the chemical separation facilities in the 200 Areas (Figure 2-7).

Fuel elements would frequently rupture and, after discharge to the fuel storage basin, would be sectioned for examination. These ruptured fuel elements caused the shielding water to become highly contaminated. Newell (1964) describes fuel ruptures and examinations that occurred during 1964 and states that there were 10 ruptures at $100-D$ and 22 at $100-D R$. It is known that detailed examinations were performed on each ruptured fuel element that could be positively identified (occasionally the ruptured fuel element could not be isolated from the other fuel elements) (Newell 1964). Occasionally, fuel elements would rupture or become damaged during handling and storage, causing contamination to the basin shielding water. Experience at other Hanford reactors suggests that the occurrence and inspections of these fue 1 ruptures almost certainly occurred at both $D$ and DR basins throughout their operating histories.

Basin water level was lowered upon closure of the reactors, and both basins were further cleaned out during 1984. The remaining water was processed and released to ponds (116-D-10 and 116-DR-10) excavated specifically for the purpose of disposal of the treated water.

An asphalt emulsion (ATCO Asphalt 1840, tradename expired) was applied to the floors and walls of the basins to fix loose contamination. The remaining basin hardware, perfs, buckets, and sludge were packaged and disposed of as low-level radioactive waste in the 200 Area burial grounds (Miller and Steffes 1986) (Figure 2-8).

\subsubsection{Decontamination Solutions}

During reactor operations and reactor shutdowns, large quantities of decontamination solutions were used routinely to remove radionuclides from facility equipment and surfaces. Decontamination activities took place at the $D$ and DR Reactor dummy decontamination facilities, cushion corridor decontamination stations, and the 108-D Maintenance Building. 
Figure 2-7. 105-D Fuel Storage Basin.

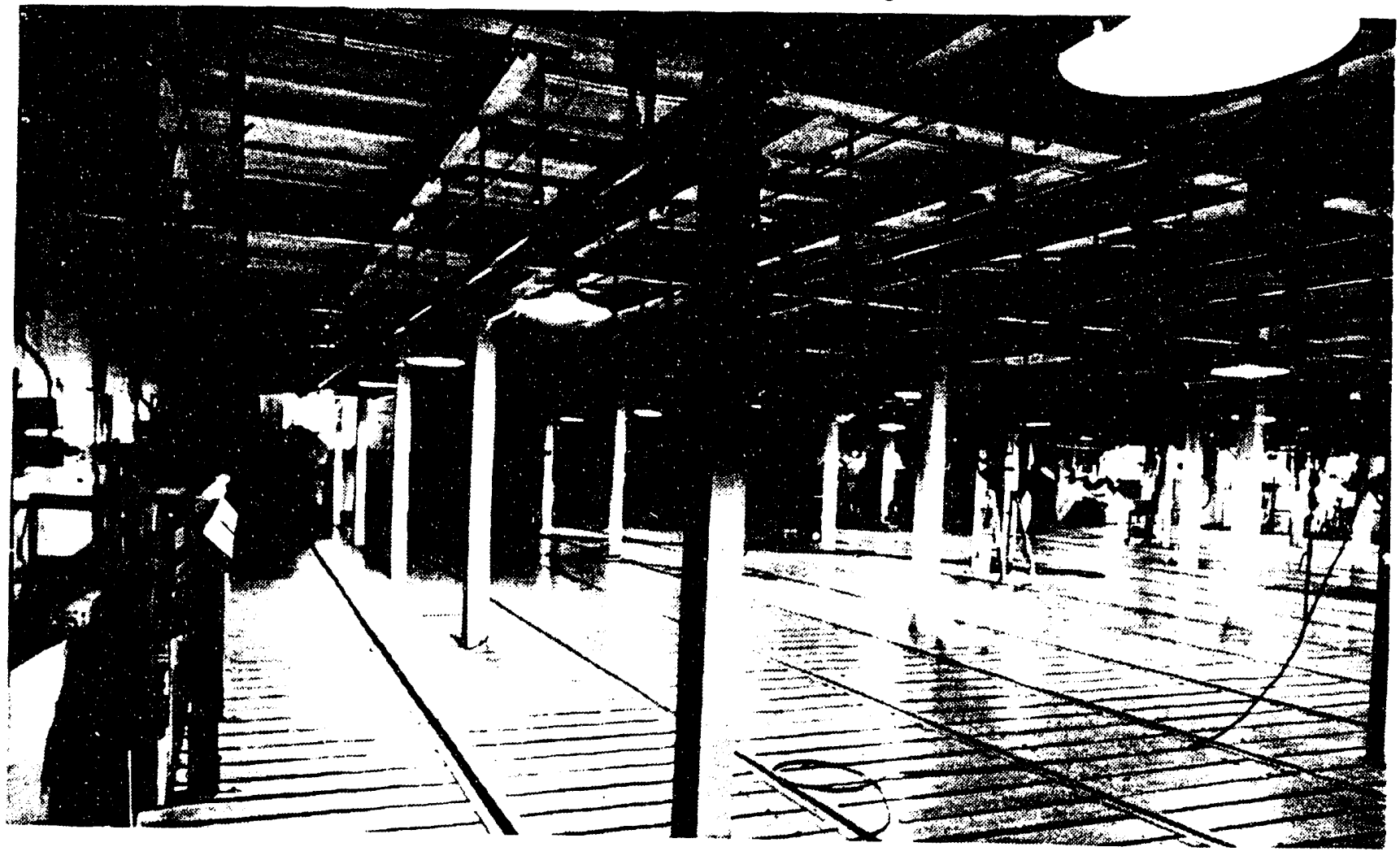

Figure 2-8. 105-D Fuel Storage Basin During Cleanout.

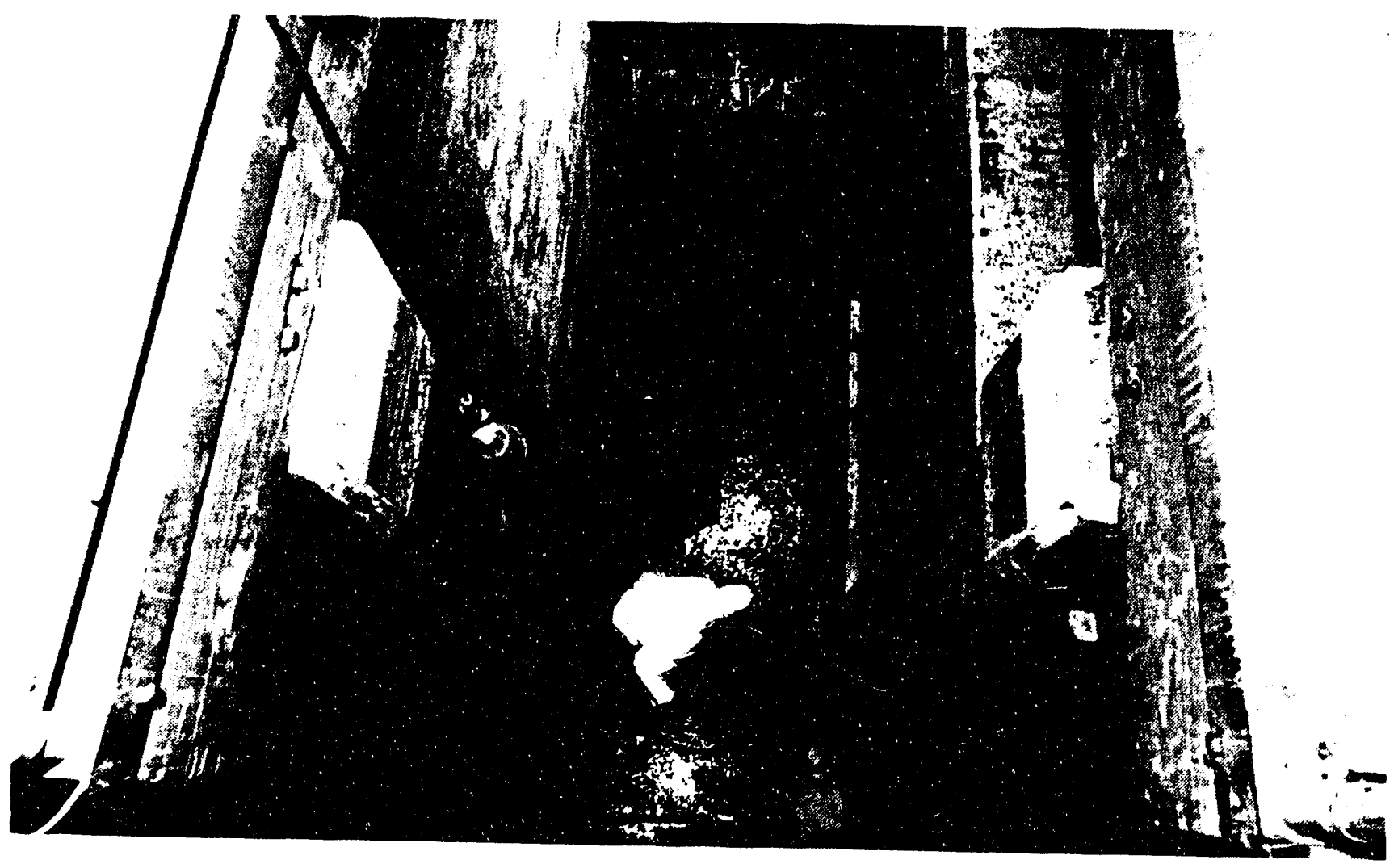


Known decontamination solutions included chromic, citric, oxalic, nitric, sulfamic, and sulfuric acids (neutralized with sodium carbonate before disposa1), and sodium fluoride. Other chemicals, including organic solvents, were al so used for some decontamination processes. These solutions were generally disposed of in cribs, trenches, and/or french drains in the immediate vicinity of the building where they were used. Detailed descriptions of the known decontamination solution disposal sites is provided in the applicable operable unit descriptions within this document.

Decontamination solutions were occasionally combined with reactor cooling water and discharged to the river. The solutions contained both radionuclide and chemical contaminants. Some of the compounds used in the decontamination solutions, such as oxalate and organic complexants, may have potentially solubilized and transported radionuclides and metals. The quantities of decontamination soiutions, as well as other disposal locations, are not known (DOE 1992a).

\subsubsection{Radioactive Sludges and Solid Wastes}

Several thousand tons of radioactive sludge were generated during reactor operations and accumulated in pipes in the cooling water effluent system, in the 116-D-7 and 116-DR-9 retention basins, and in the reactor fuel storage basins. Smaller volumes of sludge also collected in water traps located in the 115-D/DR (132-D-1) Gas Treatment Facility and in the 117-D (132-D-2) and 117-DR Air Treatment Buildings. The sludge consisted of diatomaceous earth, which was used periodically to scour internal surfaces of the reactor process tubes, and fine particulate matter, which originated from pipe slag, rust, failed fuel elements, graphite powder, dissoived and suspended solids in river water, and other undefined solids. The sludge was contaminated with radionuclides and various chemical contaminants. The total volume of sludge generated during reactor operation is unknown.

The bulk of the sludge accumulated in the 116-D-7 and 116-DR-9 retention basins and the reactor fuel storage basins. At least once during reactor operations, an unknown quantity of sludge was removed from the 116-D-7 and 116-DR-9 retention basins to burial sites adjacent to the basins.

Approximately $1.2 \times 10^{6} \mathrm{~kg}$ in $116-D-7$ and $1.9 \times 10^{6} \mathrm{~kg}$ in $116-D R-9$ of sludge is estimated to remain in each of the retention basins (Dorian and Richards 1978).

Radioactive solid wastes generally consisted of reactor components, contaminated equipment, tools, and miscellaneous contaminated items (paper, rags, structural concrete, etc.). The main source of these wastes was reactor operations, and the most highly contaminated solid wastes were the reactor components. These included aluminum spacers, lead-cadmium reactor neutronpoison pieces, boron splines, graphite, process tubes, and lead. Lesser quantities of gunbarrels, thimbles, control rods, nozzles, pigtails, and cadmium sheets were also present (Miller and Wahien 1987). 
Neutron activation of elements in the reactor components caused them to become irradiated. In addition, both the reactor components and other solid objects received surface contamination from contact with radioactive solutions and environments. The predominant radionuclides associated with the reactor components are cobalt-60 and nicke1-63. Much of the solid waste from the reactors resulted from the following two reactor modification projects:

- The Ball 3X Project, in which the liquid boron system for emergency reactor control was modified to a system using solid boron steel and carbon steel balls

- The tube replacement project, in which 3,972 (100-D) and 2,649 (100-DR) aluminum reactor process tubes were replaced between 1956 and 1965 (Dorian and Richards 1978).

It is likely that other facilities associated with the 100-D and 100-DR Reactors and with waste management activities generated radioactive solid wastes. Examples are air filters used in the 132-D-1 Gas Recirculation Building and the 132-D-2 Exhaust Air Filter Building, equipment used in connection with the cooling water effluent system, and contaminated dirt removed from near the effluent lines.

The primary disposal areas for the 100-D Area were the 118-D-1, 118-D-2, and 118-D-3 burial grounds located in the 100-DR-: Operable Unit. Irradiated reactor components removed during the 100-D/DR Ball $3 X$ system installations were buried in the 118-D-5 burial ground and at other burial sites near each reactor.

Other radioactive solid waste buried within the boundaries of the 100-D Area primarily include building foundations, contaminated underground concrete lined tunnels and piping systems, pieces of concrete, and other materials from demolished buildings. Contamination in these cases resulted mainly from surface contact with contaminated air, dust, and liquid solutions. In cases where decontamination and decommissioning have occurred, radiation levels are low (DOE 1992b).

\subsubsection{Reactor Ventilation System and Inert Gas System Wastes}

There were two gas systems associated with each of the reactors: the primary ventilation system and the inert gas system.

The primary ventilation system circulated fresh air from the staffed areas of the reactor buildings into zones of increasing contamination levels and upward past the reactors to overhead ducts. The ducts carried the air to exhaust fan systems located adjacent to the exhaust stacks. Air in the reactor buildings became contaminated with radionuclides that were present as radioactive gases, entrained vapors, and particulates generated by the cascade of cooling water in the reactors. These emissions may have resulted in surface contamination in the 100-D Area, as evidenced by the presence of carbon-14 in vegetation. Other radionuclides associated with gaseous emissions include tritium and iodine-129 (Figure 2-9). 
WHC-SD-EN-TI-181, Rev. 0

Figure 2-9. Typical Confinement Facility Layout.

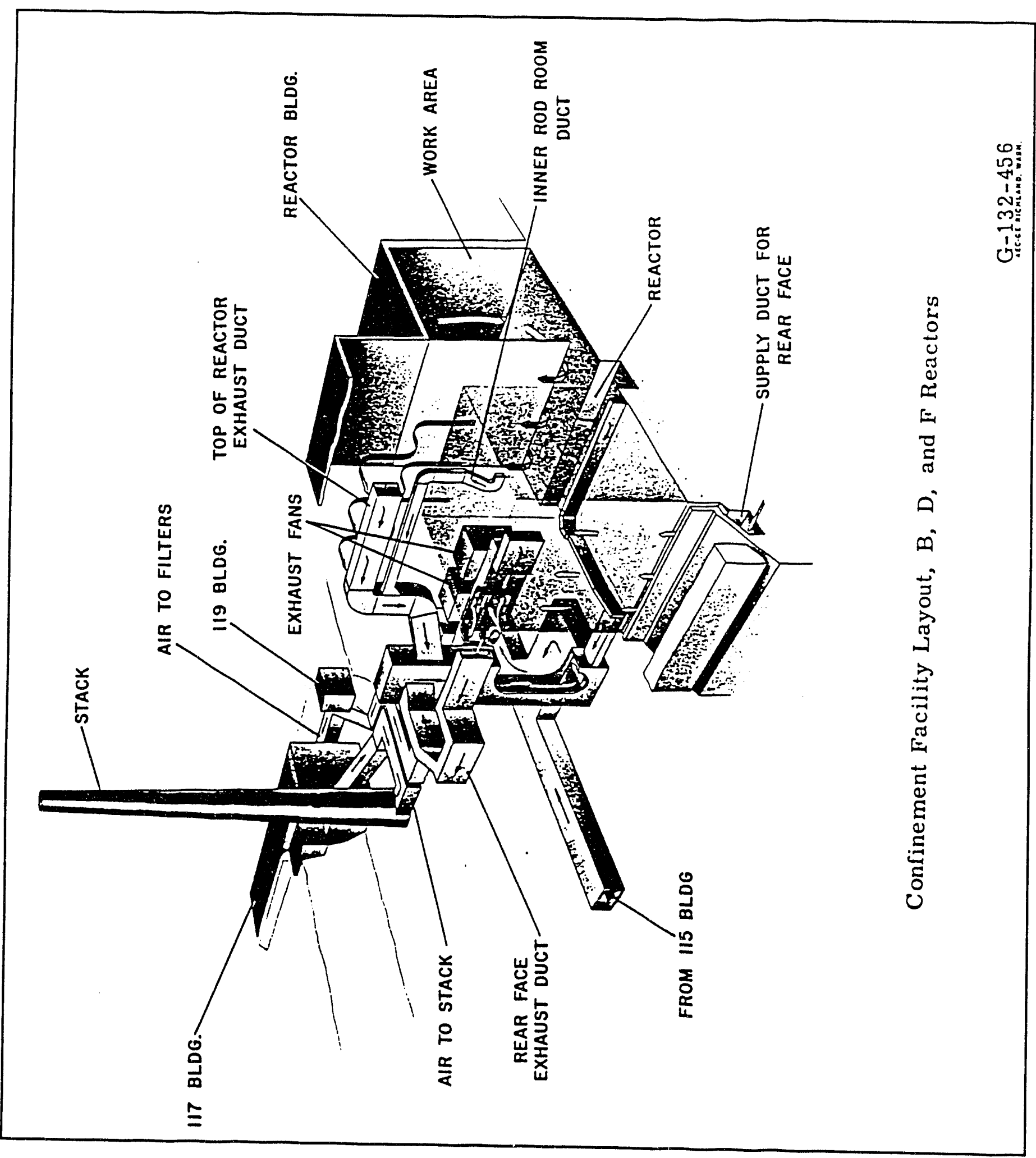


Originally, the ventilation air was released directly from the reactor buildings to the stacks and subsequently to the atmosphere. In 1960, air filtering systems were added to minimize the release of radioactive matter. These filtering systems were placed underground in the 117-D and 117-DR Buildings just south of the reactor buildings. The exhaust air passed downward through ducts to tunnels leading to the filtering buildings. After filtration, the air was routed back through a second set of tunnels to the exhaust stacks. Two types of filter banks were used: a High Efficiency Particulate Absolute (HEPA) bank and a Halogen (activated charcoal) bank.

The inert gas system's purpose was to provide a closed-loop nonreactive gas environment in the graphite cores that would remove moisture and gases from the cores and serve as a heat transfer medium between the cores and the process tubes. The 115-D/DR (132-D-1) Gas Recirculating Facility provided service to both reactors.

The system also served to detect water leaks within the reactor cores. A mixture of helium and carbon dioxide, driven at low pressure by a blower system, was circulated through the graphite piles. Filters, gas coolers, blowers, condensers, and silica gel drying towers were located in the building. The system maintained gas pressure in the reactors at a slightly positive value with respect to the ventilation air so that outside air could not make contact with the graphite cores. When a leak was detected, the gas was routed to the ventilation exhaust systems.

Contamination of the 117-D and 117-DR Buildings occurred on concrete surfaces, the inside surfaces of ducts, machinery, and filters as indicated by analysis of smear samples taken from these surfaces (Dorian and Richards 1978). Samples obtained during decommissioning of the 117-D (132-D-2) Building revealed that the inside surfaces of the concrete-lined tunnels, the equipment, and the wall surfaces of the fan rooms and filter chambers had lowlevel, surface-smear-able, radioactive contamination. The 115-D/DR Building was connected by tulinels to the reactor buildings; the interior of these tunnels were also radioactively contaminated (DOE 1992b).

\subsection{SANITARY LIQUID WASTES}

Sanitary wastes were produced in various 100-D Area buildings equipped with sanitary farilities. These wastes were routed by sewer lines to septic tanks and drain fields. Non-sanitary wastes such as detergents, cleaning compounds, and solvents likely entered these sewer systems. There are no records of radiological wastes being disposed of to these systems (DOE 1992b). There are five known and three suspect septic tank systems located within the 100-D Area. See sections 4.28, 5.12, and 6.9 for more information.

\subsection{NONRADIOACTIVE LIQUID WASTES}

Nonsanitary, nonradioactive liquid chemicals potentially contributed to 100-D Area liquid waste sites. These include hazardous wastes and hazardous substances. 
Contamination from liquids (including gasoline, diesel fuel, solvents, and other chemical compounds) would be expected near above- and below-ground storage tanks and their piping systems and in areas where these materials were used or stored. Releases could have resulted from leakage, spillage, or disposal. The following activities may have resulted in the generation of nonradioactive liquid wastes and may require further data investigation:

- Water treatment chemicals (alum, sulfuric acid, chlorine, and sodium dichromate) were used and stored near the 108-D, 185-D, and 183-DR Buildings.

- Wet-type electrical transformers and hydraulic machinery containing oil contaminated with polychlorinated biphenyls (PCBs) were used at several locations within the 100-D Area. Fluids contaminated with PCBs may have been released or disposed of during operation, equipment repair, or decommissioning and demolition activities.

- Ash from the coal-fired powerhouse (184-D) was passed as a water slurry by pipeline to the 126-D-1 ash pit. Leakage in the pipeline and seepage at the ash pit were potential liquid contamination sources.

- Boiler water treatment chemicals for the 184-D powerhouse included sodium sulfate, tri-sodium phosphate, and chromates. These chemicals were used to treat the boiler water and ended up in the boiler sludge. Disposal methods for this sludge are not known.

- Three zeolite water softeners were located in the 184-D Powerhouse where filtered water was treated before use in the heat exchangers. $\mathrm{NaCl}$ (salt) solutions were used to regenerate the zeolite ion exchange beds in the water softener tanks. The salt was delivered in railcar lots to brine pits located adjacent to railroad tracks just northwest of the powerhouse. The disposal method of the waste from this process is not known and there is no record of leaks or spills.

- Fuel oil tanks both underground and aboveground were located in the 100D Area. One such fuel tank is located just west of the 184-DA Steam Generating Building, which was constructed and placed in operation following plant shutdown and deactivation. The tank size is unknown. The second tank, 166-D, was an aboveground $681,300 \mathrm{~L}(180,000 \mathrm{gal})$ diesel fuel storage tank. This tank was located at the confluerice of the railroad tracks north of the 184-D Powerhouse. Associated with this tank is a 137-m (450-ft) fuel oil line that transported the oil to the boilers. The tank has been removed; it is unknown if the oil line was removed (DOE 1992b).

- Emergency electrical power for instrumentation in the 105-D Reactor Building consisted of two backup systems: a 10-kVA gasoline engine generator for the station in general and a set of batteries for the $\mathrm{Ball}$ $3 X$ systems. The storage tank for the gasoline engine was mounted above ground at the rear of the 1821-D Facility.

- Oils, painis, and solvents were stored and used in the 1714-D, 1715-D, and 1716-D Luildings. 
- Automotive repair and service was performed at the 1716-D Building.

- Additional wastewater was generated from various cleaning processes. Disposal locations for these solutions are unknown (DOE 1992b).

\subsection{NONRADIOACTIVE SOLID WASTES}

Nonradioactive solid waste generated in the 100-D Area primarily included miscellaneous materials such as paper, trash, pieces of metal, plastic parts, etc., generated in the facilities. The 128-D-1 burn pit is a site at which combustible wastes were disposed (Stenner et al 1988). The 128-D-2 and 628-3 burn pits served a similar purpose and also received non-contaminated hardware.

Other solid wastes consisted of relatively uncontaminated concrete, metal parts, and other materials generated during decommissioning and demolition activities. Asbestos, chemical waste, and contaminated solids were removed from the area to the 200 Area burial grounds during the decontamination and decommissioning work. Building materials which were not considered to be contaminated were buried in place or, in some cases, sold to salvage contractors as excess materials and removed from the site (Wahlen 1991).

Solid waste generating operations associated with the 184-D Powerhouse consisted of an anthracite coal storage yard and the 126-D-1 ash disposal pit. Leachates may have entered the soil at these sites and along the coal conveyor system. 


\subsection{SOIL AND VEGETATION SAMPLING}

Routine environmental surveillance of the 100-D Area is conducted by WHC to evaluate long-term trends in environmental accumulation of radioactivity. Soil and vegetation samples are collected on a regular basis and analyzed for radioisotope content.

Early each summer, soil and vegetation samples are collected and submitted for radioanalysis. The analyses include those radionuclides (i.e., gammaemitting radionuclides, strontium, uranium, and plutonium isotopes) expected to be found in the areas sampled. The results are compared to regional background levels, which are derived from PNL offsite monitoring data, to determine the difference between contributions from Hanford operations and from natural causes and world-wide fallout. The results are also compared to soil contamination standards developed for use by WHC at the Hanford Site (Schmidt et al 1991).

Tables 3-1 and 3-2 provide the results of 100-D Area soil and vegetation sampling from 1981 through 1991. Soil samples were taken from the surface. Soil and vegetation sample data, broken down by sample site, is not provided here due to length, but is available in the referenced document.

Table 3-1. Average Radionuclide Concentrations ( $\mathrm{pCi} / \mathrm{g}$ ) Detected in the 100-D Area Surface Soil Samples from 1981 to 1991.

\begin{tabular}{|c|c|c|c|c|c||}
\hline Year & ${ }^{60} \mathrm{Co}$ & ${ }^{90} \mathrm{Sr}$ & ${ }^{137} \mathrm{CS}$ & ${ }^{238} \mathrm{Pu}$ & ${ }^{239 / 240} \mathrm{Pu}$ \\
\hline 1981 & $3.60 \mathrm{E}-01$ & $\mathrm{NR}$ & $4.00 \mathrm{E}-01$ & $\mathrm{NR}$ & $\mathrm{NR}$ \\
\hline 1982 & $4.90 \mathrm{E}-01$ & $\mathrm{NR}$ & $3.20 \mathrm{E}-01$ & $\mathrm{NR}$ & $\mathrm{NR}$ \\
\hline 1983 & $4.20 \mathrm{E}-01$ & $\mathrm{NR}$ & $1.70 \mathrm{E}-01$ & $\mathrm{NR}$ & $\mathrm{NR}$ \\
\hline 1984 & $2.20 \mathrm{E}-01$ & $1.40 \mathrm{E}-01$ & $1.60 \mathrm{E}-01$ & $1.40 \mathrm{E}-04$ & $9.80 \mathrm{E}-03$ \\
\hline 1985 & $2.40 \mathrm{E}-01$ & $5.60 \mathrm{E}-02$ & $2.70 \mathrm{E}-01$ & $2.10 \mathrm{E}-04$ & $3.00 \mathrm{E}-03$ \\
\hline 1986 & $2.60 \mathrm{E}-01$ & $7.30 \mathrm{E}-02$ & $8.70 \mathrm{E}-01$ & $3.20 \mathrm{E}-04$ & $5.80 \mathrm{E}-03$ \\
\hline 1987 & $2.80 \mathrm{E}-01$ & $2.00 \mathrm{E}-01$ & $1.10 \mathrm{E}+00$ & $1.60 \mathrm{E}-03$ & $1.80 \mathrm{E}-02$ \\
\hline 1988 & $1.90 \mathrm{E}-01$ & $1.50 \mathrm{E}-01$ & $9.40 \mathrm{E}-01$ & $6.20 \mathrm{E}-04$ & $8.20 \mathrm{E}-03$ \\
\hline 1989 & $2.20 \mathrm{E}-01$ & $8.80 \mathrm{E}-02$ & $6.70 \mathrm{E}-01$ & $6.20 \mathrm{E}-04$ & $1.40 \mathrm{E}-02$ \\
\hline 1990 & $9.30 \mathrm{E}-02$ & $9.80 \mathrm{E}-02$ & $9.50 \mathrm{E}-01$ & $6.20 \mathrm{E}-04$ & $2.90 \mathrm{E}-02$ \\
\hline 1991 & $1.10 \mathrm{E}-01$ & $7.00 \mathrm{E}-02$ & $9.80 \mathrm{E}-01$ & $3.10 \mathrm{E}-04$ & $9.10 \mathrm{E}-03$ \\
\hline
\end{tabular}

$N R=$ Not Reported

(Schmidt et al 1991) 
Table 3-2. Averag Radionuclide Concentrations $(\mathrm{pC} / \mathrm{g})$ Detected in the 100-D area Vegetation Samples from 1981 to 1991.

\begin{tabular}{|c|c|c|c|c|c||}
\hline YEAR & ${ }^{60} \mathrm{Co}$ & ${ }^{90} \mathrm{Sr}$ & ${ }^{137} \mathrm{CS}$ & ${ }^{238} \mathrm{Pu}$ & ${ }^{239 / 240} \mathrm{Pu}$ \\
\hline 1981 & $1.20 \mathrm{E}+00$ & $\mathrm{NR}$ & $1.60 \mathrm{E}-01$ & $\mathrm{NR}$ & $\mathrm{NR}$ \\
\hline 1982 & $1.10 \mathrm{E}-01$ & $\mathrm{NR}$ & $2.70 \mathrm{E}+00$ & $\mathrm{NR}$ & $\mathrm{NR}$ \\
\hline 1983 & $9.50 \mathrm{E}-02$ & $\mathrm{NR}$ & $1.40 \mathrm{E}-01$ & $\mathrm{NR}$ & $\mathrm{NR}$ \\
\hline 1984 & $2.10 \mathrm{E}-01$ & $2.80 \mathrm{E}-01$ & $1.70 \mathrm{E}+00$ & $1.80 \mathrm{E}-03$ & $5.80 \mathrm{E}-04$ \\
\hline 1985 & $2.40 \mathrm{E}-01$ & $6.90 \mathrm{E}-02$ & $6.80 \mathrm{E}-01$ & $1.20 \mathrm{E}-04$ & $7.00 \mathrm{E}-04$ \\
\hline 1986 & $2.70 \mathrm{E}-01$ & $1.50 \mathrm{E}-01$ & $1.70 \mathrm{E}+00$ & 0.0 & $3.10 \mathrm{E}-04$ \\
\hline 1987 & $2.50 \mathrm{E}-01$ & $9.50 \mathrm{E}-02$ & $6.30 \mathrm{E}-01$ & $1.60 \mathrm{E}-04$ & $2.80 \mathrm{E}-04$ \\
\hline 1988 & $2.80 \mathrm{E}-01$ & $1.80 \mathrm{E}-01$ & $9.60 \mathrm{E}-02$ & $3.80 \mathrm{E}-05$ & $1.90 \mathrm{E}-04$ \\
\hline 1989 & $2.60 \mathrm{E}-01$ & $1.50 \mathrm{E}-01$ & $2.80 \mathrm{E}-01$ & $9.60 \mathrm{E}-05$ & $1.20 \mathrm{E}-04$ \\
\hline 1990 & $6.10 \mathrm{E}-02$ & $9.50 \mathrm{E}-02$ & $6.20 \mathrm{E}-01$ & $<2.40 \mathrm{E}-05$ & $2.60 \mathrm{E}-04$ \\
\hline 1991 & $5.70 \mathrm{E}-02$ & $8.30 \mathrm{E}-02$ & $1.80 \mathrm{E}-01$ & $2.90 \mathrm{E}-05$ & $1.10 \mathrm{E}-03$ \\
\hline
\end{tabular}

NR $=$ Not reported

(Schmidt et al 1991) 


\subsection{0-DR-1 OPERABLE UNIT}

This section describes the 100-DR-1 Operable Unit, which encompasses the northern portion of the 100-D Area and includes the sites of all 100-D Reactor encompasses 39 acilities, some of which are active and in use today. It Facility Agreement and Consent 19 of which are included in the Hanford Federal 1989). These include decommissioned (Tri-Party Agreement) (Ecology et al. drains, septic tanks, burial grounds, facilities, trenches, cribs, french

The relative locations of the 100-DR-1, 100-DR-2, and 100-DR-3 0perable Units are shown in Appendix B (B-3). A map of the 100-DR-1 Operable Unit can also be found in Appendix $B(B-4)$. Additional figures (B-7, B-8, B-9, and B10) are included in Appendix $B$ to provide clarity for each waste type deused to identify years, different alpha-numeric numbering systems have been coincides with Waste Information facilities. The most current system, which this report to identify all sites.

Table 4-1 identifies the sites for which a PNL Hazard Ranking System Migration score (HRS Migration score) has been established. Not all of the waste sites located within the 100-DR-1 Operable Unit have had HRS Migration 4.1 through 4.41.

Table 4-1. Hazard Ranking System Migration Scores.

\begin{tabular}{|c|c|}
\hline WASTE SITE NUMBER & HRS MIGRATION SCORE \\
\hline $116-D-1 A$ & 9.13 \\
\hline $116-D-1 B$ & 42.32 \\
\hline $116-D-2$ & 9.13 \\
\hline $116-D-3$ & 8.64 \\
\hline $116-D-4$ & 8.64 \\
\hline $116-D-6$ & 0.00 \\
\hline $116-D-7$ & 76.91 \\
\hline $116-D-9$ & 0.00 \\
\hline $116-D R-1$ & 42.32 \\
\hline $116-D R-2$ & 42.32 \\
\hline $116-D R-9$ & 76.91 \\
\hline
\end{tabular}

(Stenner et al 1988) 


\subsection{6-D-1A (105-D STORAGE BASIN TRENCH \#1)}

The 116-D-1A trench is an inactive liquid waste site that operated from 1947 to 1952. The 130- by 10- by 6-ft-deep trench is located at Hanford coordinates $N 92230$ W52480, which is $100 \mathrm{ft}$ east of the 105-D Reactor Building (118-D-6) and immediately north of the railroad tracks leading to the 105-D Building.

The trench received and estimated $200,000 \mathrm{~L}$ of contaminated water and sludge from the 105-D fuel storage basin (WHC 1991). The estimated radionuclide inventory, in curies decayed through April 1, 1986, includes the following:

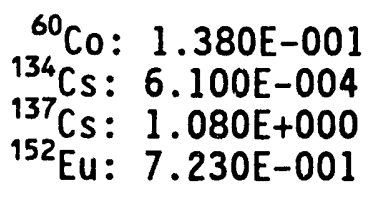

${ }^{154} \mathrm{Eu}: 1.130 \mathrm{E}-001$

${ }^{155} \mathrm{Eu}: 3.470 \mathrm{E}-002$

$3 \mathrm{H}: 8.810 \mathrm{E}-002$

${ }^{239} \mathrm{Pu}: 1.800 \mathrm{E}-002$ $\begin{aligned}{ }^{240} \mathrm{Pu}: & 2.000 \mathrm{E}-003 \\ { }^{90} \mathrm{Sr}: & 1.230 \mathrm{E}-001 \\ { }^{235} \mathrm{U}: & 3.000 \mathrm{E}-005 \\ { }^{238} \mathrm{U}: & 3.760 \mathrm{E}-003\end{aligned}$

(Stenner et al 1988)

In addition, the hazardous chemical inventory includes $1,000 \mathrm{~kg}$ of sodium dichromate (WHC 1991).

Dorian and Richards (1978) reports the results of soil samples taken from four locations. It further reports the trench volume as $2.1 \times 10^{5} \mathrm{ft}^{3}$ and the mass as $1.4 \times 10^{10} \mathrm{~g}$. The full tables are provided in Appendix $C$ and are summarized in Tables 4-2 and 4-3. Compare the "Curies" column to the Stenner et al (1988) data provided above.

Table 4-2. 116-D-1A Radionuclide Inventory.

\begin{tabular}{||c|c|c||}
\hline RADIONUCLIDE & AVE. $\mathrm{pCi} / \mathrm{g}$ & CURIES \\
\hline${ }^{238} \mathrm{Pu}$ & & 0.0 \\
\hline${ }^{239 / 240} \mathrm{Pu}$ & $1.40 \mathrm{E}^{+00}$ & $2.00 \mathrm{E}^{-02}$ \\
\hline${ }^{90} \mathrm{Sr}$ & $1.10 \mathrm{E}^{+01}$ & $1.50 \mathrm{E}^{-01}$ \\
\hline${ }^{3} \mathrm{H}$ & $9.70 \mathrm{E}^{+01}$ & 1.40 \\
\hline${ }^{152} \mathrm{Eu}$ & $7.60 \mathrm{E}^{+01}$ & 1.10 \\
\hline${ }^{60} \mathrm{Co}$ & $2.90 \mathrm{E}^{+01}$ & $4.10 \mathrm{E}^{-01}$ \\
\hline${ }^{154} \mathrm{Eu}$ & $1.60 \mathrm{E}^{+01}$ & $2.20 \mathrm{E}^{-01}$ \\
\hline${ }^{134} \mathrm{CS}$ & $6.90 \mathrm{E}^{-01}$ & $9.70 \mathrm{E}^{-03}$ \\
\hline${ }^{137} \mathrm{CS}$ & $9.00 \mathrm{E}^{+01}$ & 1.30 \\
\hline${ }^{155} \mathrm{Eu}$ & $7.60 \mathrm{E}^{+00}$ & $1.10 \mathrm{E}^{-01}$ \\
\hline $\mathrm{U}$ & $2.70 \mathrm{E}^{-01}$ & $3.80 \mathrm{E}^{-03}$ \\
\hline TOTAL CURIES & & 4.70 \\
\hline
\end{tabular}

(Dorian and Richards 1978) 
Table 4-3. 116-D-1A Radionucl ide Inventory.

\begin{tabular}{|c|c|}
\hline RADIONUCLIDE & AVE. $\mathrm{pCi} / \mathrm{g}$ \\
\hline $\begin{array}{l}\text { Ave. } \\
\text { Beta/Gamma }\end{array}$ & $3.30 \mathrm{E}^{+02}$ \\
\hline $\begin{array}{l}\text { Max. } \\
\text { Beta/Gamma }\end{array}$ & $9.00 \mathrm{E}^{+02}$ \\
\hline $\begin{array}{l}\text { Ave } 239 / 240 \mathrm{Pu} \\
\text { Max. }\end{array}$ & $1.40 \mathrm{E}^{+00}$ \\
\hline $239 / 240 \mathrm{Pu}$ & $6.10 \mathrm{E}^{+00}$ \\
\hline
\end{tabular}

(Dorian and Richards 1978)

There is some question about whether this trench might actually have been a crib. It is described as a crib in Hanford Drawings H-1-26426 and M-1904DR. Further evidence is found in Tatum (1967), which states: "A covered crib Building. It was used to dispose of decontamination solutions and water from the 105-D washpad." No trench is apparent in aerial photographs taken during the early 1950's, when the trench should have been active. An open trench at the site is only apparent in photographs taken in 1955 during a major expansion of the cooling water system, Project CG-558, and it is believed that this trench was unrelated to the 116-D-1A crib (Figure 4-1).

Figure 4-1. Project CG-558, 1955.

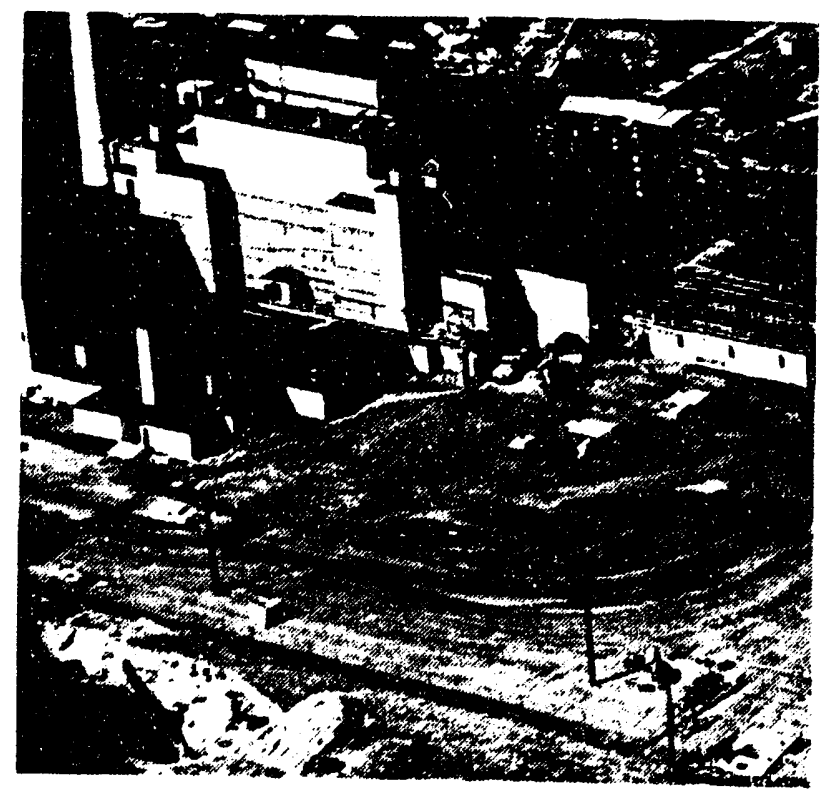

The 116-D-1A appears today as a cobble-covered field. Additional soil has been added as shielding to a portion of the trench, and the surface is built up about 1 to $2 \mathrm{ft}$ above the surrounding surface area. There is a $11 / 4-i n$. stainless stee 1 pipe which extends about 36 in. above grade at the location of this waste site. It appears to be a vent pipe. The trench is treated annually with defoliant and no vegetation grows on the surface. The waste site is unfenced and is included in a larger area that is marked by permanent concrete monuments and Underground Radioactive Material warning signs. No markers uniquely identify the trench as the 116-D-1A site (Figure 4-2).

This waste site has an HRS Migration score of 9.13 (Stenner et al, 1988). 
Figure 4-2. 116-D-1A, 1993.

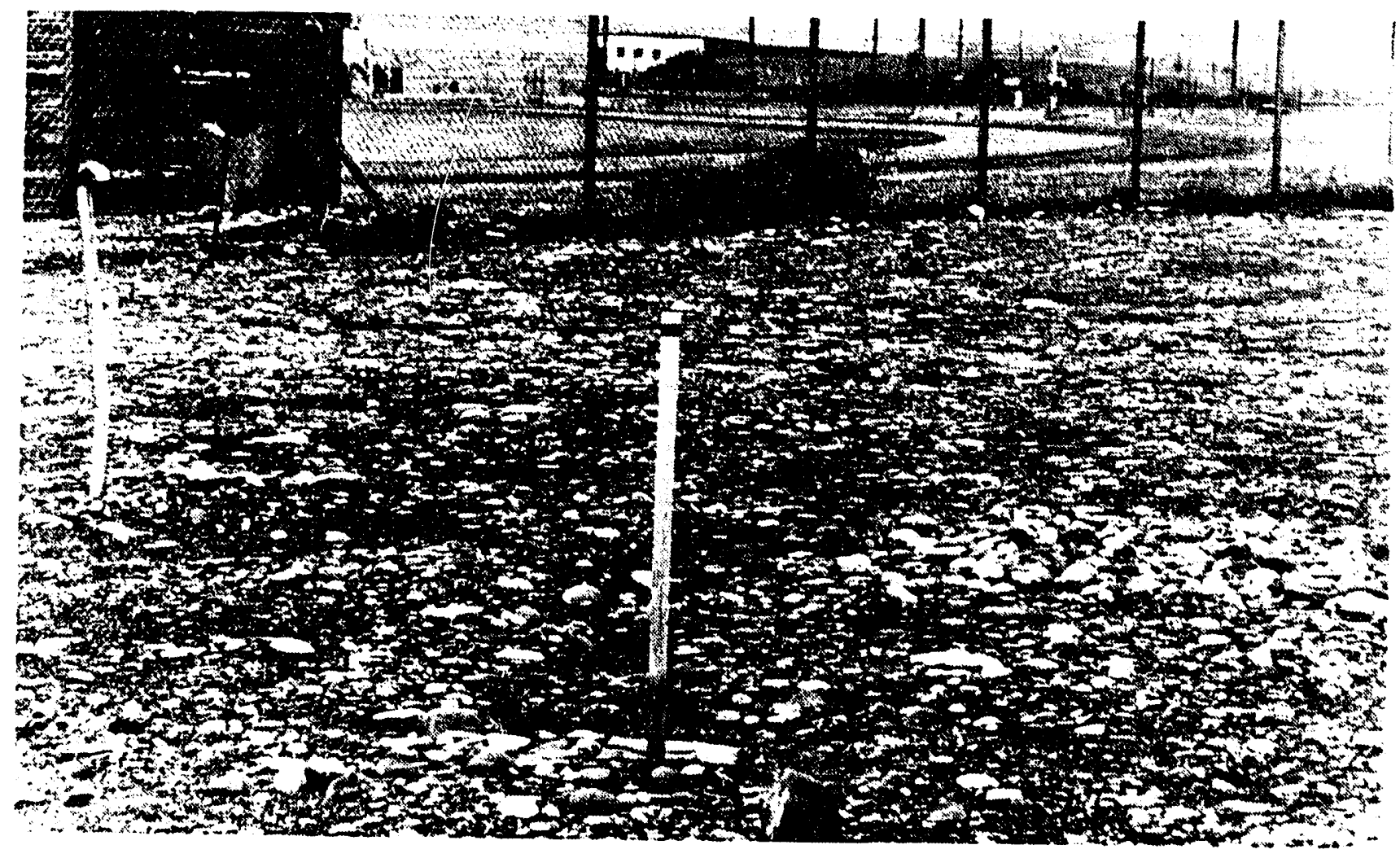

\subsection{6-D-1B (105-D STORAGE BASIN TRENCH *2)}

The 116-D-1B trench is an inactive liquid waste site that operated from 1953 to 1967 . The 100- by 10- by 15-ft-deep trench is located at Hanford coordinates $\mathrm{N} 92300 \mathrm{W52570}$, which is $100 \mathrm{ft}$ northeast of the 105-D Reactor Building (118-D-6). The 116-D-1B trench received contaminated water and sludge from the 105-D fuel storage basin and contaminated liquid wastes from the decontamination of fuel spacers and reactor hardware (WHC 1991). This trench began operations when the 116-D-1A trench ceased operations.

The 116-D-1B received an estimated $8,000,000 \mathrm{~L}$ of liquid wastes. The estimated radionuclide inventory, in curies decayed through April 1, 1986,
includes the following:

$\begin{array}{rr}{ }^{60} \mathrm{Co}: 6.750 \mathrm{E}-002 & { }^{154} \mathrm{Eu}: 4.270 \mathrm{E}-002 \\ { }^{134} \mathrm{Cs}: 3.100 \mathrm{E}-004 & { }^{155} \mathrm{Eu}: 2.780 \mathrm{E}-001 \\ { }^{137} \mathrm{Cs}: 5.130 \mathrm{E}-001 & { }^{3} \mathrm{H}: 1.260 \mathrm{E}-001 \\ { }^{152} \mathrm{Eu}: 2.830 \mathrm{E}-001 & { }^{239} \mathrm{Pu}: 6.030 \mathrm{E}-003\end{array}$

(Stenner et al 1988) $\begin{aligned} &{ }^{240} \mathrm{Pu}: 6.700 \mathrm{E}-004 \\ &{ }^{90} \mathrm{Sr}: 1.640 \mathrm{E}-001 \\ &{ }^{235} \mathrm{U}: 2.000 \mathrm{E}-005 \\ &{ }^{238} \mathrm{U}: 2.480 \mathrm{E}-003\end{aligned}$ 
In addition, the hazardous chemical inventory includes $700 \mathrm{~kg}$ of sodium dichromate, $2000 \mathrm{~kg}$ of sodium oxalate, $2000 \mathrm{~kg}$ of sodium sulfamate (WHC 1991), and $2000 \mathrm{~kg}$ of sodium formate (DOE 1992b). Additionally, DOE-RL (1991b) reports that $2000 \mathrm{~kg}$ of sodium oxalate (rather than sodium formate) was disposed of at this location.

Dorian and Richards (1978) reports the results of soil samples taken from four locations. It further reports the trench volume as $2.1 \times 10^{5} \mathrm{ft}^{3}$ and the mass as $1.4 \times 10^{10} \mathrm{~g}$. The full tables are provided in Appendix $C$ and are summarized in Tables 4-4 and 4-5. Compare the "Curies" column to the Stenner et al (1988) data provided above.

Table 4-4. 116-D-1B Radionuclide Inventory.

\begin{tabular}{|c|c|c||}
\hline RADIONUCLIDE & AVE. $\mathrm{PCi} / \mathrm{g}$ & CURIES \\
\hline${ }^{238} \mathrm{Pu}$ & & 0.0 \\
\hline${ }^{239 / 240} \mathrm{Pu}$ & $4.80 \mathrm{E}^{-01}$ & $6.70 \mathrm{E}^{-03}$ \\
\hline${ }^{90} \mathrm{Sr}$ & $1.40 \mathrm{E}^{+01}$ & $2.00 \mathrm{E}^{-01}$ \\
\hline${ }^{3} \mathrm{H}$ & $1.40 \mathrm{E}^{+01}$ & $2.00 \mathrm{E}^{-01}$ \\
\hline${ }^{152} \mathrm{Eu}$ & $3.10 \mathrm{E}^{+01}$ & $4.30 \mathrm{E}^{-01}$ \\
\hline${ }^{60} \mathrm{CO}$ & $1.40 \mathrm{E}^{+01}$ & $2.00 \mathrm{E}^{-01}$ \\
\hline${ }^{154} \mathrm{Eu}$ & $5.90 \mathrm{E}^{+00}$ & $8.30 \mathrm{E}^{-02}$ \\
\hline${ }^{134} \mathrm{CS}$ & $3.50 \mathrm{E}^{-01}$ & $4.90 \mathrm{E}^{-03}$ \\
\hline${ }^{137} \mathrm{CS}$ & $4.40 \mathrm{E}^{+01}$ & $6.20 \mathrm{E}^{-01}$ \\
\hline${ }^{155} \mathrm{Eu}$ & $6.30 \mathrm{E}^{+01}$ & $8.80 \mathrm{E}^{-01}$ \\
\hline$U$ & $1.80 \mathrm{E}^{-01}$ & $2.50 \mathrm{E}^{-03}$ \\
\hline TOTAL CURIES & & 2.60 \\
\hline
\end{tabular}

(Dorian and Richards 1978)

Table 4-5. 116-D-1B Radionuclide Inventory.

\begin{tabular}{||c|c|}
\hline RADIONUCLIDE & AVE. PCi/g \\
\hline $\begin{array}{l}\text { Ave. } \\
\text { Beta/Gamma }\end{array}$ & $2.00 \mathrm{E}^{+02}$ \\
\hline $\begin{array}{l}\text { Max. } \\
\text { Beta/Gamma }\end{array}$ & $1.10 \mathrm{E}^{+03}$ \\
\hline $\begin{array}{l}\text { Ave } 239 / 240 \mathrm{Pu} \\
\text { Max } \\
239 / 240 \mathrm{Pu}\end{array}$ & $4.80 \mathrm{E}^{-01}$ \\
\hline
\end{tabular}

(Dorian and Richards 1978) 
There is some question about whether this trench might actually have been a crib. The site is described as a crib by Hanford Drawing H-1-26426. No trench is apparent in aerial photographs taken in the early 1950's when the trench should have been active. An open trench at this site is only apparent in photographs taken in 1955 during a major expansion of the cooling water system, Project CG-558, and it is believed that this trench was unrelated to the crib.

The 116-D-1B trench has been fully backfilled with clean soil and appears today as a cobble-covered field built up 1 to $2 \mathrm{ft}$ above the surrounding surface grade. The site has been treated with defoliant and no vegetation grows on the surface. It is unfenced and is included in a larger area that is marked by permanent concrete monuments and Underground Radioactive Material warning signs. No markers uniquely identify the trench as the 116-D-1B site (Figure 4-3).

This waste site has an HRS Migration score of 42.32 (Stenner et al 1988).

Figure 4-3. 116-D-1B, 1993.

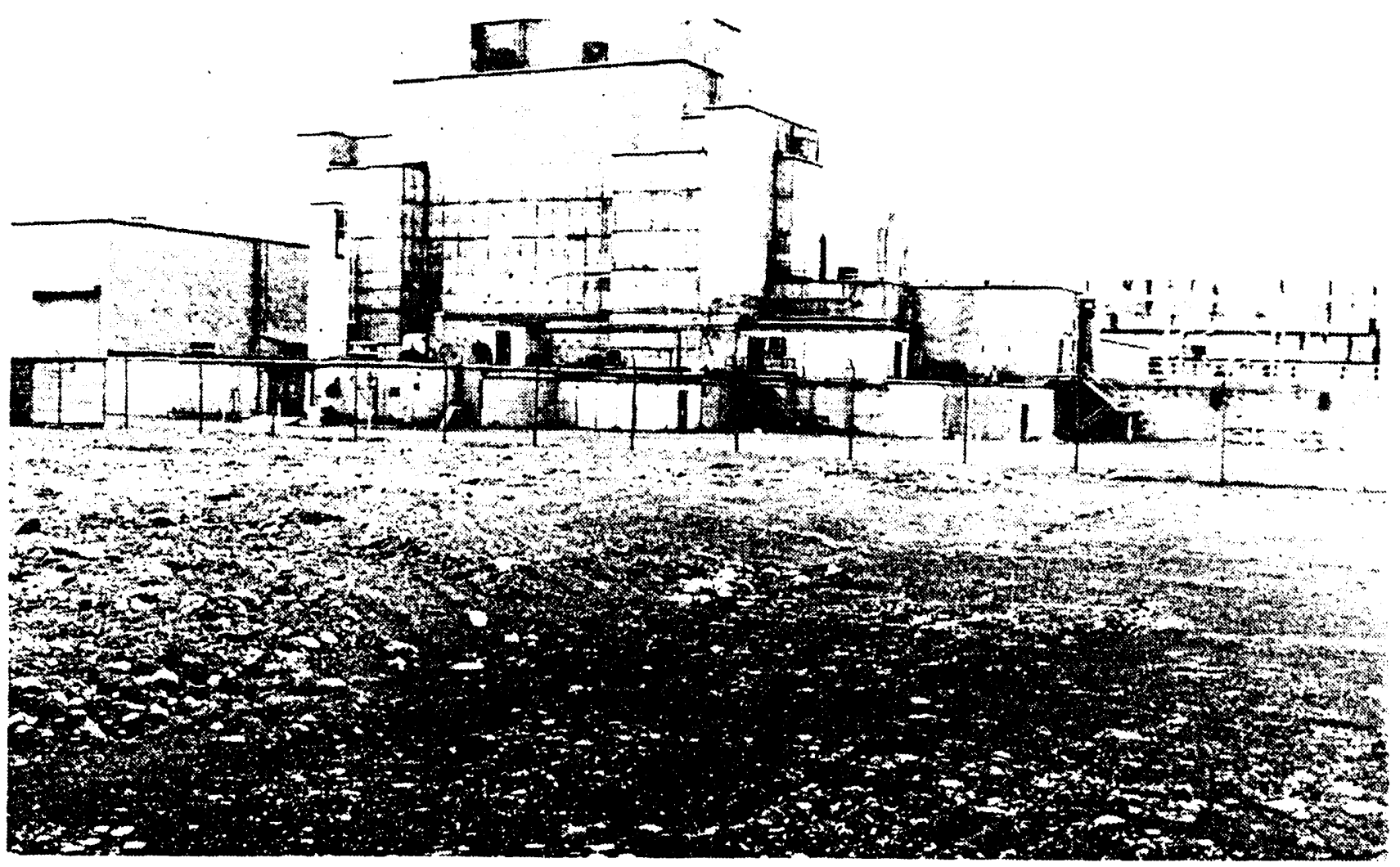




\subsection{6-D-2 (105-D PLUTO CRIB)}

The 116-D-2 pluto cribs are inactive liquid waste sites that operated from 1950 to 1952 (WHC 1991) and possibly as late as 1956 (ERDA 1975). There were two pluto crib sites associated with the 105-D Reactor. The first, located at Hanford coordinates N91900 W52640, is suspected to have been a hole dug for only one use and was the one sampled by Dorian and Richards in 1976. The second, located at Hanford coordinates $N 91970$ W52610, is thought to be the main pluto crib. This site was not visible during soil sampling activities in 1976 but is about $100 \mathrm{ft}$ east of the 115-D/DR Gas Treatment Facility (132-D-1) (WHC 1991). The second pluto crib is a 10 - by 10 - by $10-\mathrm{ft}$-deep box which is filled with sand and shored with railroad ties. This site was at one time marked above ground by a concrete monument that no longer stands (Heid 1956).

The pluto cribs received an estimated 4,000 $\mathrm{L}$ of liquid wastes (Stenner et a) 1988) that included an estimated hazardous chemical inventory of $0.004 \mathrm{~kg}$ of sodium dichromate (WHC 1991).

No radionuclide inventory data is available for these pluto cribs.

Pluto cribs were used to isolate the coolant flow from process tubes containing ruptured fuel elements until the ruptured fuel could be discharged. The isolation was performed by the installing a pluto valve on the down stream end (rear face side) of the process tube and attaching a rubber hose. The coolant then flowed through the rubber hose to the pluto crib.

The crib was set in the ground with its upper surface at grade. It had a hatch which was opened only when required to accept the rubber hose. The use of pluto cribs was discontinued when liquid waste trenches came into use. Prior to pluto cribs, process tubes containing fuel ruptures were not isolated and contaminated cooling water was flushed to the Columbia River through the effluent system (Appendix D, D-5).

Confusion exists about the location of these two pluto crib sites; there are three separate locations identified for them. The first is located just north of the rail tracks leading into the 105-D fuels transfer area and just south of the 1821-D Emergency Gasoline Generator Building that corresponds to the Hanford coordinates given above. This site currently has a steel rod marking its approximate location. It is shown in Figure 4-4. The second location is southeast of the 105-D Building and was identified during a walkover in February 1992 (WHC 1992). The site is marked by a recently placed concrete marker with a brass identification medallion embedded in the surface (Figure 4-5). The third location is located about $70 \mathrm{ft}$ south and $30 \mathrm{ft}$ west of the second site. This location was identified by ground probing radar (GPR) survey. A test hole drilled at the site appeared to confirm the location as the pluto crib (WHC 1992). This site is also marked by a recently placed concrete marker with a brass identification medallion embedded in the surface and is identified as 116-D-2A (Figure 4-6). This final site may be the location of a solid waste burial ground unrelated to the pluto cribs and is discussed in Section 4.33 . 
WHC-SD-EN-TI-181, Rev. 0

Figure 4-4. Possible Location of the 116-D-2 Pluto Crib, 1993.

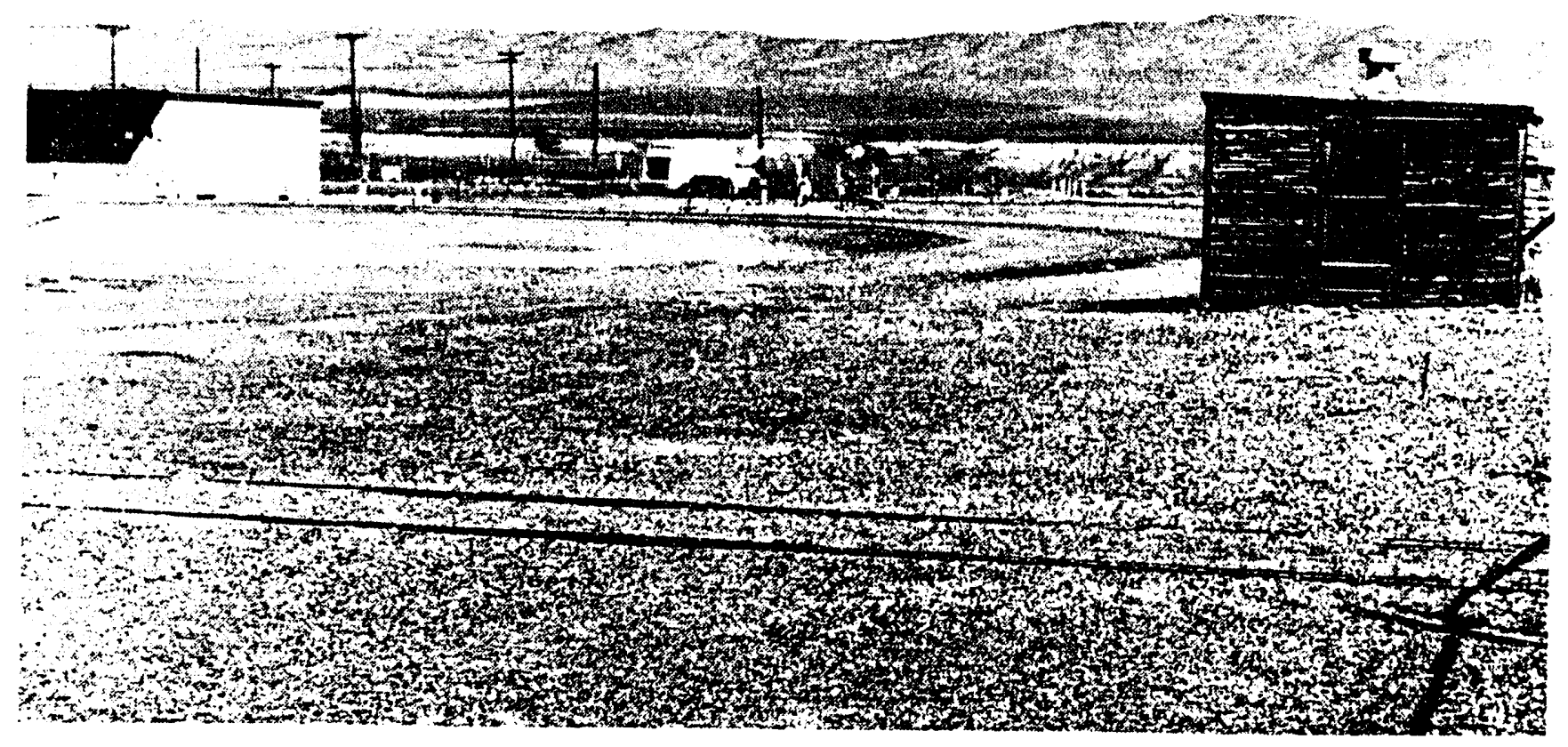

Figure 4-5. Possible Location of Pluto Crib \#2.

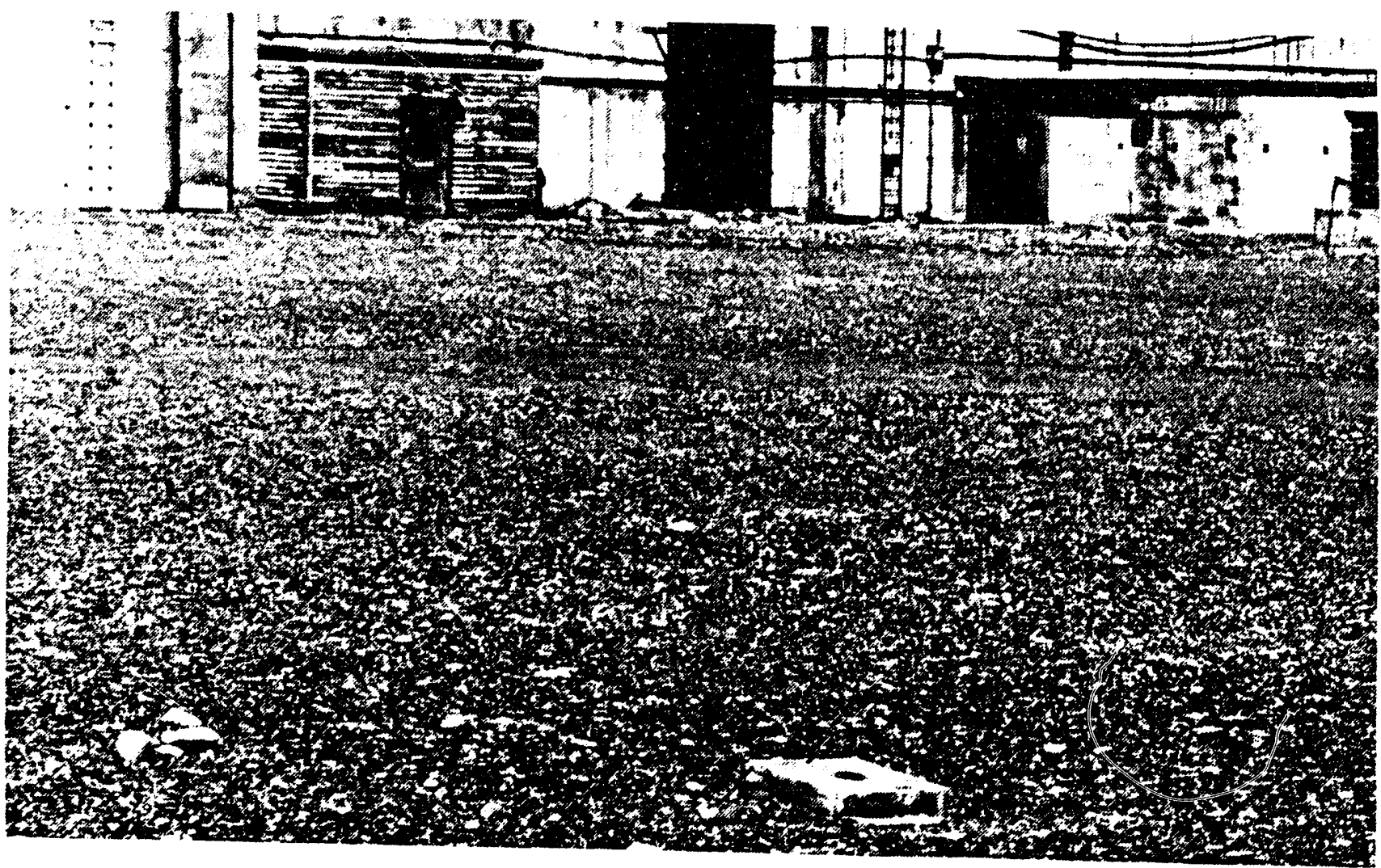


Figure 4-6. Possible Location of the Pluto Crib \#3.

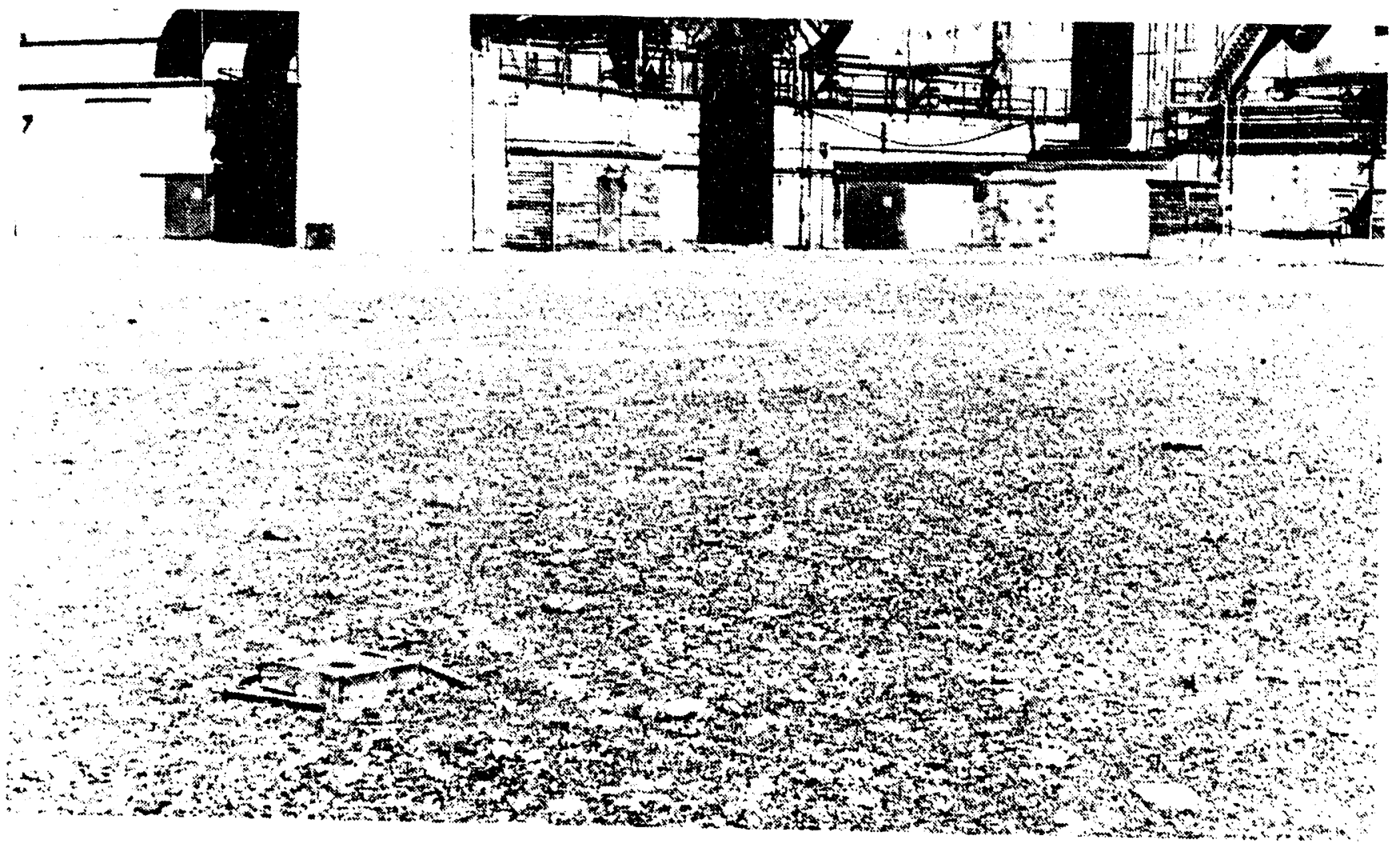

The 116-D-2 cribs have been fully backfilled with 10 feet of soil and appear today as unmarked gravel covered fields. All of the crib sites are within the exclusion area security fence but have no fencing unique to the
cribs.

This waste site is a registered underground injection well (DOE 1988) and has an HRS Migration score of 9.13 (Stenner et al 1988).

\subsection{6-D-3 FRENCH DRAIN (108-D CRIB *1)}

The 116-D-3 french drain, commonly known as the 108-D crib \#1, is an inactive liquid waste site that operated from 1951 to 1967 . It is 1ocated at Hanford coordinates $\mathrm{N} 92700$ W52575, which is directly east of the 108-D received an estimat. It is a 3 -ft-diameter by 5 -ft-deep french drain that contaminated maintenance shop and cask decontaminaid wastes from the 108-D included contaminated shop and cask decontamination pad. This liquid waste level fission products (Stenner et al 1988).

The radiological inventory includes $8.180 \mathrm{E}^{-002} \mathrm{Ci}$ Beta (WHC 1991). No other radiological inventory information could be found for this waste site.

Conflicting descriptions and locations were found in the reference documents and are listed below. 
- Physical descriptions: $15 \mathrm{ft}$ deep (DOE 1988), 8 feet square (Clukey 1954), and $10 \mathrm{ft}$ diameter by $20 \mathrm{ft}$ deep (Clukey 1956)

- Hanford coordinate locations: N92780 W52780 (Stenner et al 1988) and N92300 W52700 (PNL 1991).

The site appears today as a vegetation-free cobble-covered field within the 100-D Area fence just northwest of the exclusion area fence. A recently placed concrete marker with a brass identification medallion embedded in the surface identifies this waste site (Figure 4-7). The 116-D-3 is a registered underground injection well (DOE 1988) and has an HRS score of 8.64 (Stenner et a) 1988).

Figure 4-7. 108-D French Drain \#1.

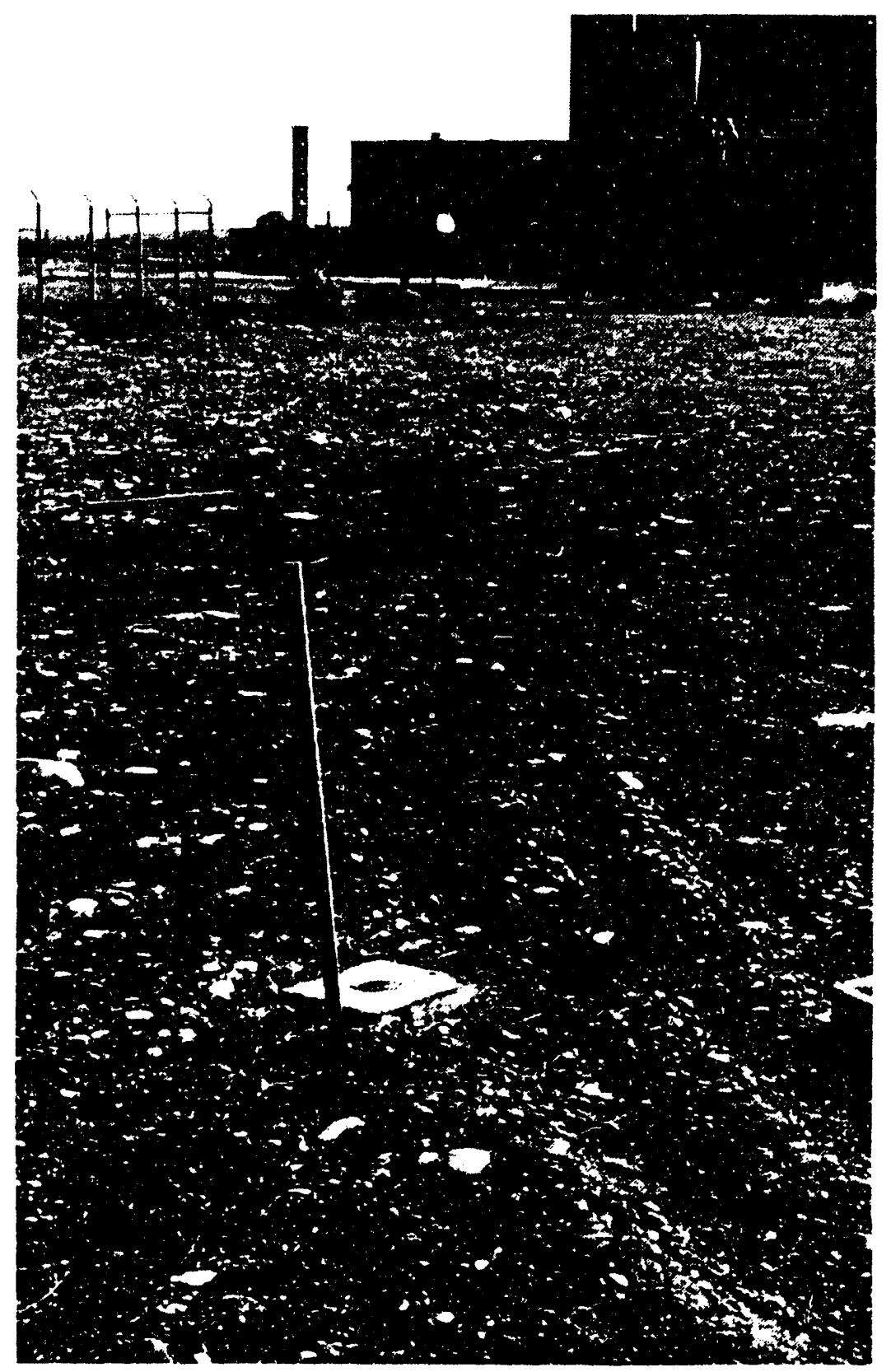




\subsection{6-D-4 FRENCH DRAIN (108-D Crib \#2)}

The 116-D-4 french drain, commonly known as the 108-D crib \#2, is an inactive liquid waste site that operated from 1956 to 1967 (ERDA 1975). It is located at Hanford coordinates $\mathrm{N} 92675 \mathrm{W52650}$, which is $100 \mathrm{ft}$ east of the 108$D$ building (WHC 1991). The drain is $3 \mathrm{ft}$ diameter by $5 \mathrm{ft}$ deep (Stenner et al 1988). It received an estimated $30,000 \mathrm{~L}$ of contaminated liquid wastes from the 108-D contaminated maintenance shops and technical laboratory. The liquid wastes included contaminated water, decontamination solutions, solvents, and low-level fission products (PNL 1991).

Figure 4-8. 108-D French Draiñ \#2.

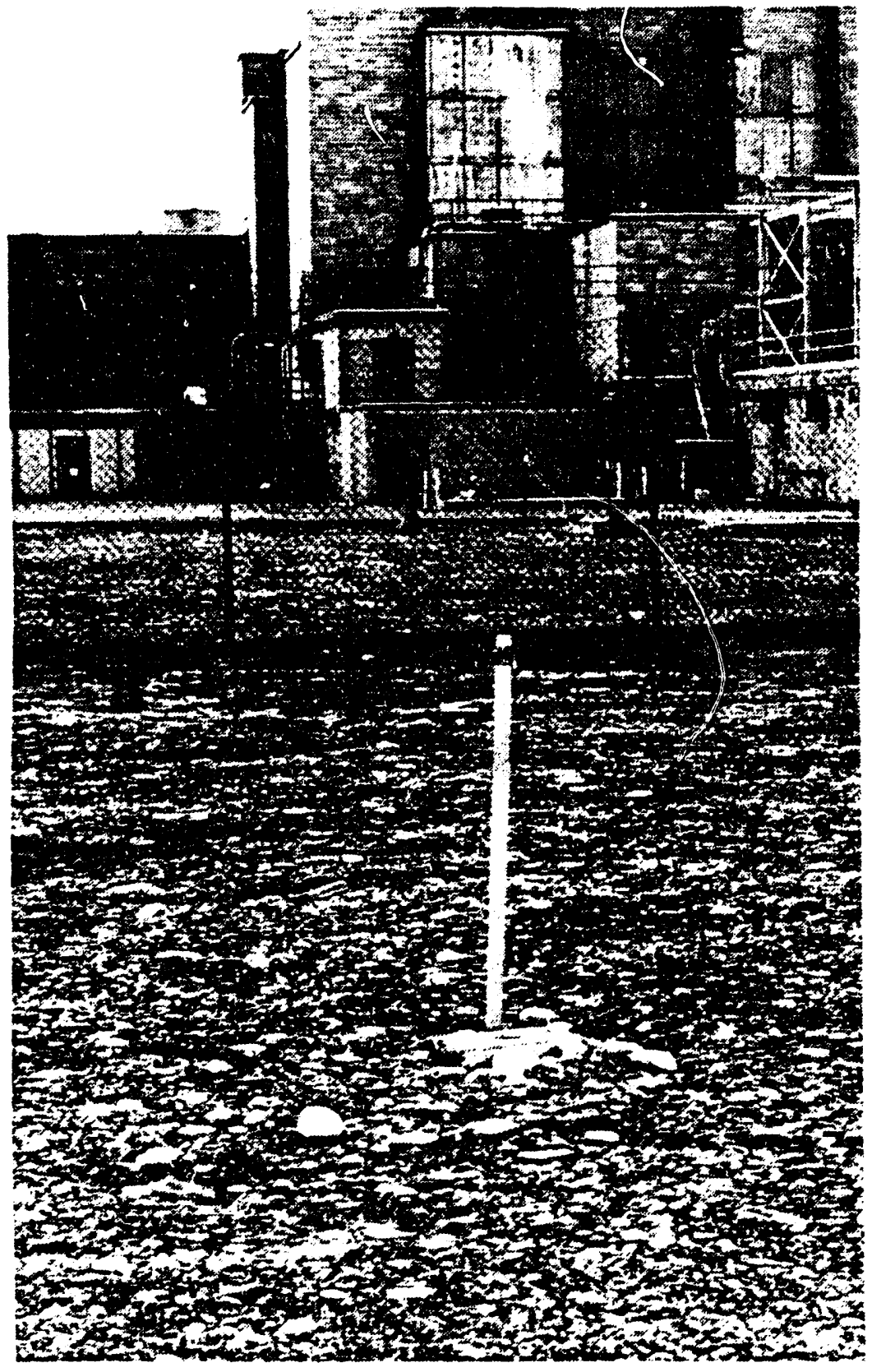

There is some conflicting data concerning this french drain. Heid (1956) reports that the crib was dug in 1951 and was covered by $8 \mathrm{ft}$ of soil. Stenner et al (1988) reports its location as Hanford coordinates $N 92300$ W52620.

The radiological inventory includes $8.180 \mathrm{E}^{-002}$ Ci Beta (WHC 1991). No other radiological information could be found for this waste site.

The site appears today as a vegetation-free, cobble-covered field. It is marked by a recently placed concrete marker with a brass identification medallion embedded in the surface, located about $75 \mathrm{ft}$ east of the 100-D Area fence. It is within a larger radiologically controlled area bounded by permanent concrete markers posted with Underground Radioactive Material warning signs (Figure 4-8).

The 116-D-4 is a registered underground injection well (DOE 1988) and has an HRS Migration score of 3.64 (Stenner et al, 1588). 


\subsection{6-D-5 (1904-D OUTFALL STRUCTURE)}

The 116-D-5 is an inactive liquid waste site that operated from 1944 to 1967 for the disposal of reactor cooling water (WHC 1991) and to 1975 for the disposal of 100-D Area process sewer effluents (ERDA 1975). The outfall structure is located at Hanford coordinates N94634 W53645, which is about 400 $\mathrm{ft}$ west of the 107-D retention basin $(116-D-7)$ on the bank of the Columbia River. It served as a weir box for the cooling water effluents from both the 107-D (116-D-7) and 107-DR (116-DR-9) retention basins. It al so received process waste effluents from the following 100-D support facilities: 183-D, $184-D, 190-D, 185 / 189-D$, and other miscellaneous facilities having connections to the process sewer system.

Effluents passed through the outfall into two 42-in. steel pipelines that carried the effluents to the river bottom center (approximately $1,850 \mathrm{ft}$ from

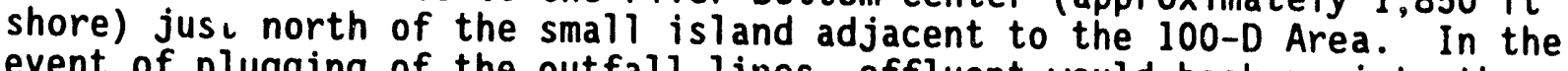
event of plugging of the outfall lines, effluent would back up into the outfall structure and overflow into an open concrete flume, or spilliway, that led to the river shoreline and was considered part of the outfall structure.

The outfall was modified during construction of the 107-DR retention basin to allow for the connection of the new 107-DR effluent lines. This modification extended the outfall south about 10 feet and required the removal of the south wall of the original concrete construction. Although no documentation could be found, it is likely that the concrete debris found on the river bank to the east of the outfall structure was generated by the outfall modifica-
tion.

The outfall structure appears today as an open, reinforced concrete structure that is enclosed by an aviary exclusion mesh cover and an 8-ft chain link fence. The 116-D-5 overflow spillway has been covered with soil from its origin to the shoreline (WHC 1991). During low river conditions, about 20 to $30 \mathrm{ft}$ of the spillway is exposed (Figures 4-9, 4-10, and 4-11).

This waste site has not been assigned an HRS Migration score.

\subsection{6-D-6 (105-D CUSHION CORRIDOR FRENCH DRAIN)}

The 116-D-6 is an inactive liquid waste site that reportedly operated from 1953 to 1967 (WHC 1991) although operation may have begun as late as 1961 (Stenner et al 1988). The 116-D-6 is located at Hanford coordinates N92300 W52720, which is directly northeast of the reactor building. It is a 3-ft-diameter by 3-ft-deep french drain made of vitreous tile conduit fed by a single 4-in. galvanized drain pipe. 
Figure 4-9. 1904-D Outfall, 1944.

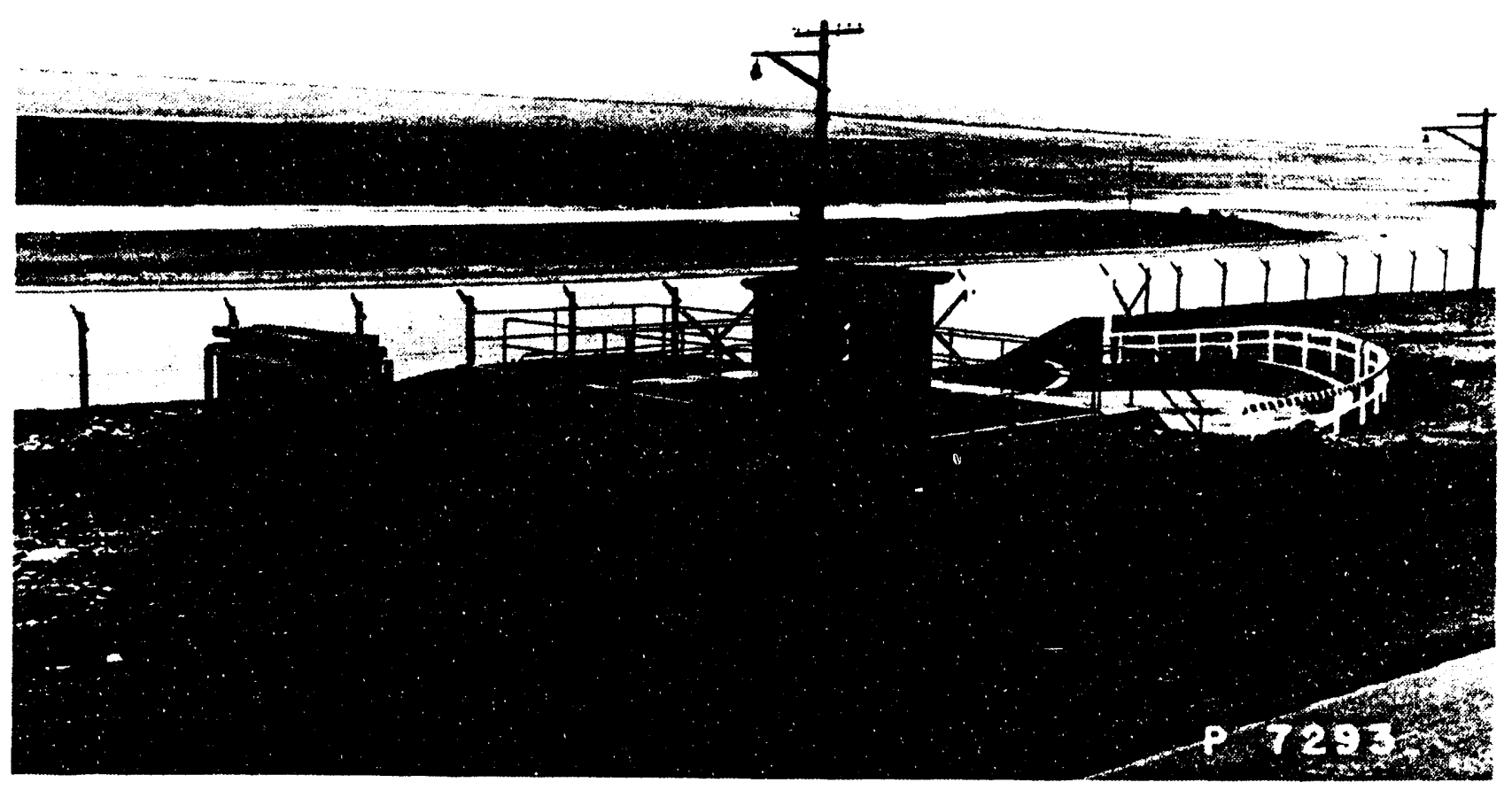

Figure 4-10. 116-D-5, 1904-D Outfall Structure, 1992.

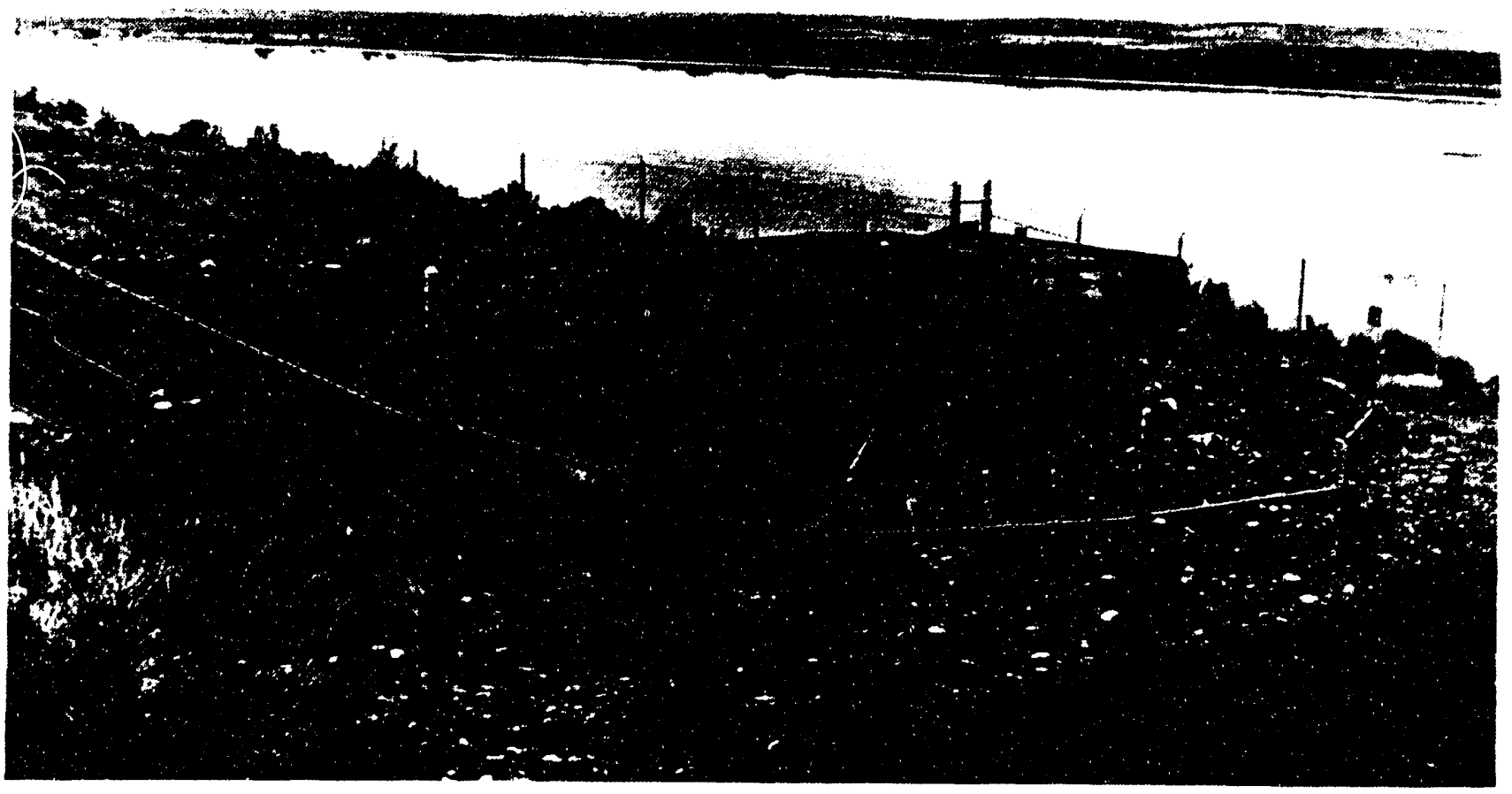




$$
\text { WHC-SD-EN-TI-181, Rev. } 0
$$

Figure 4-11. 116-D-5, 1904-D Outfall Flume, 1993.

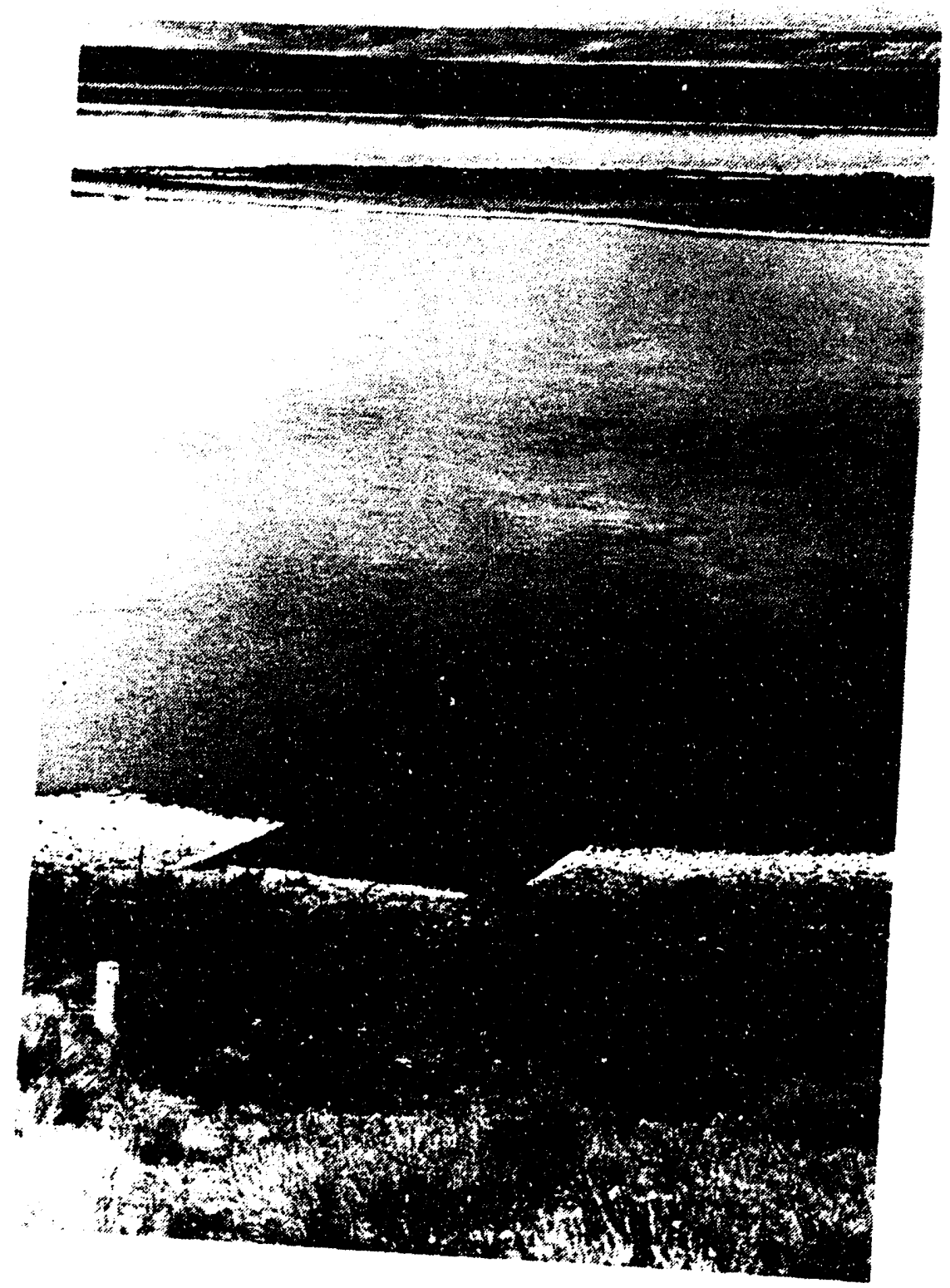

The drain received an estimated 100,000 L change room and water from the mask $100,000 \mathrm{~L}$ of domestic water from the cushion corridor. Additional decontamination effluents and socated in the nel to perform decontaminat french drain; it was common and solvents were also dose rates from the rear face of the reactor were reduced. 
Today, $116-D-6$ is almost completely covered by wind blown sand. It is surrounded by a light duty steel barricade structure bolted to an outside wall of the 105-D Facility. The elaborate physical barrier is probably due to the fact that this waste site is at the base of an outside access staircase on the northeast side of the 105-D building (Figure 4-12).

Figure 4-12. 105-D Cushion Corridor French Drain.

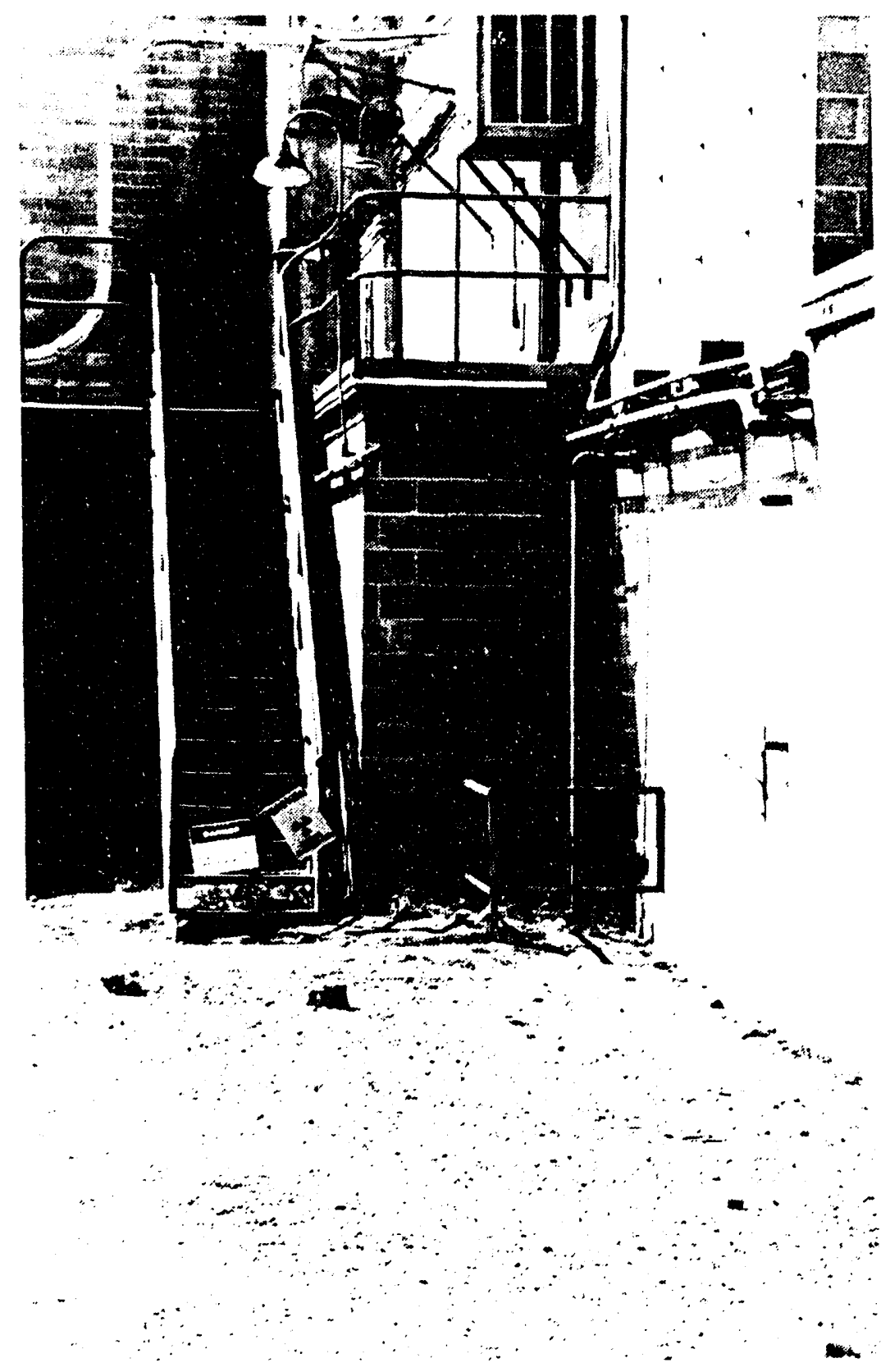

The 116-D-6 is a registered underground injection well (DOE 1988) and has an HRS Migration score of 0.00 (Stenner et al 1988). 


\subsection{6-D-7 (107-D RETENTION BASIN)}

The 116-D-7 is an inactive liquid waste site that operated from 1944 to 1967. The basin is located at Hanford coordinates $N 94685$ W53250 (northwest corner), which is about 2,100 ft north of 105-D Reactor Building. It received reactor effluents from the 105-D Reactor (WHC 1991).

The 467- by 230 - by 24-ft-deep basin was an open concrete structure with a vertical concrete divider constructed lengthwise down the middle of the basin. The floor was constructed of concrete slabs, their joints originally closed with neoprene water seals. The walls sloped from the floor to a point $10 \mathrm{ft}$ above floor level with the remaining wall (about $10 \mathrm{ft}$ ) being vertical. The sloping wall sections were $4 \mathrm{in}$. thick, and the vertical walls were made of reinforced concrete with a minimum thickness of $1 \mathrm{ft}$ at the top and $5.75 \mathrm{ft}$ at the bottom. Each side of the basin was divided into five sections by baffle walls constructed of concrete and wood. The purpose of these baffle walls was to slow and control channeling of the effluent and to maximize cooling and decay of short lived radioactive isotopes prior to release to the Columbia River (Figure 4-13).

Figure 4-13. 100-0 Area, 1944, Retention Basins.

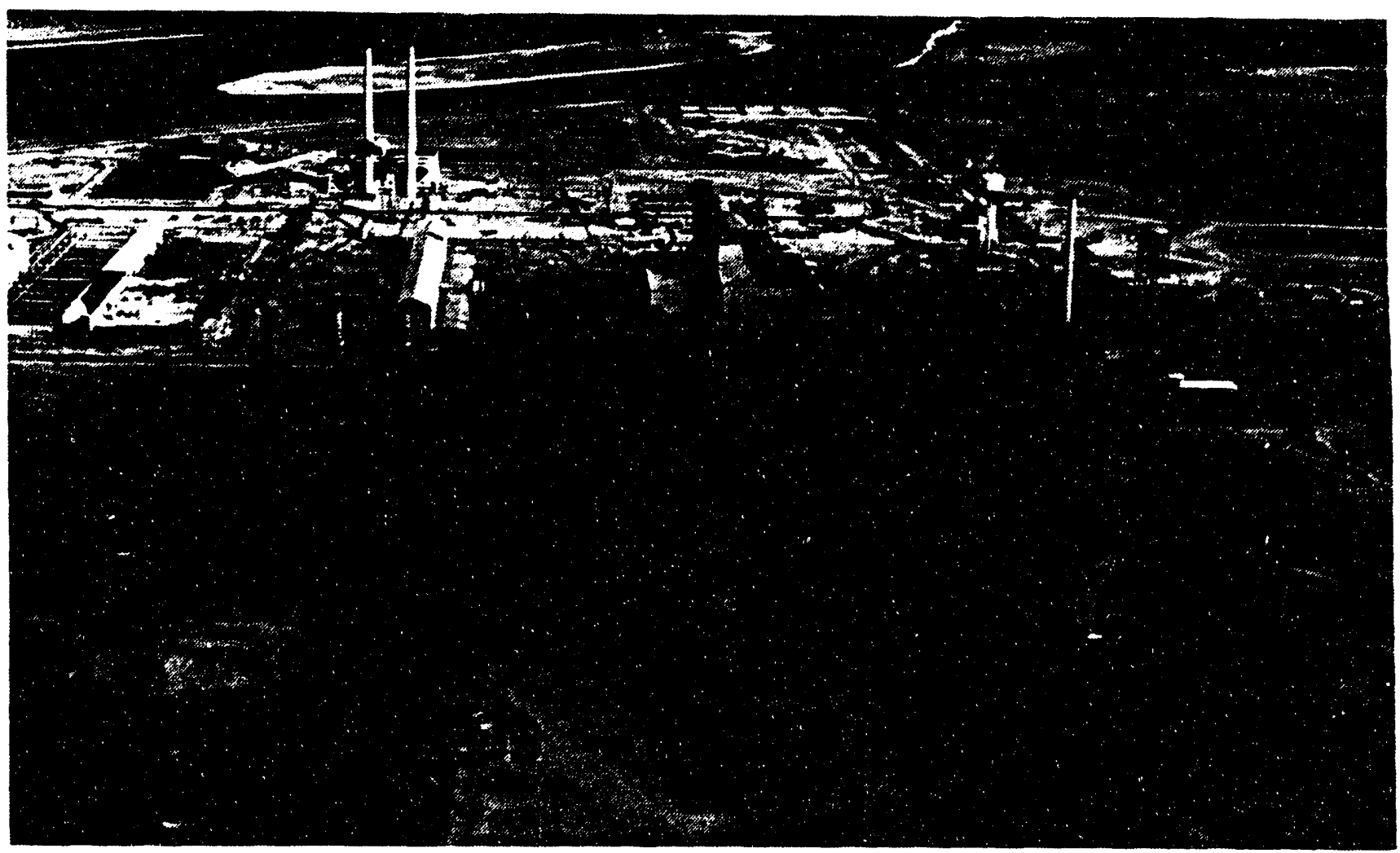


Radionuclide inventories of samples taken in the vicinity of the basin ranged from 5 to over $400 \mathrm{Ci}$. Seventy percent of the total received inventory is contained within the soil adjacent to the basin (WHC 1991). Underground contamination is greatest at the north and east sides from past leakage; measurable contamination is confined to within $100 \mathrm{ft}$ of the north wall and 25 $\mathrm{ft}$ of the other walls. Sample holes indicate that contamination beneath the floor of the basin is confined to within $6 \mathrm{ft}$ of the basin floor. Approximately $10 \mathrm{Ci}$ have leached into the concrete floor and walls (Dorian and Richards 1978).

Leakage of the cooling water effluent was common in the areas adjacent to the retention basin due to thermal expansion and contraction of the concrete panels used to form the walls and floor. Documented occurrences of major leakage of the retention basin include the following:

- In early 1950, leakage occurred on the north side between the bas in and the river. Effluent water drained under the road to the section of 1 and between the road and the perimeter fence (WHC 1991). The area is currently surrounded by permanent concrete markers posted with Underground Radioactive Materials warning signs.

- In the fall of 1951, excessive leakage was detected above ground about $150 \mathrm{ft}$ southeast of the basin. The maximum dose rate observed at the time was $50 \mathrm{mrad} / \mathrm{hr}$ at the surface. "Two excavations were made down to the effluent pipe level, the holes were covered, but effluent water continued to seep to the surface in the area" (Heid 1956). (It is assumed the holes referred to were holes in the effluent line that continued to leak after repairs were made.)

Four sludge trenches were excavated in the 107-D and 107-DR Retention Basin area for the disposal of sludge that had accumulated at the bottom of the basins. The trenches were dug in the spring of 1953 to facilitate repair of the basins by Minor Construction forces and were covered after use by about six feet of soil (Dorian and Richards 1978). The sludge disposal trenches were sampled for radionuclides in 1975. Contamination levels were indistinguishable from contamination in the surrounding soil caused by basin 1eakage. The approximate coordinates of the trenches are N94600 W52591, N94453 W52888, N94511 W52092, and N94252 W52039 (WHC 1991). These sludge trenches were also identified by Clukey (1956) as being located at Hanford coordinates $N 94450$ W52850, N94460 W53200, N94750 W53180, N94600 W52110, N94635 W52575, and N94100 W52600.

The sludge trench site located at Hanford coordinates N94252 W52039 is shown as having received fuel rupture liquid wastes (Hanford Drawing $\mathrm{H}-\mathrm{l}-$ 4046). It is al so shown as being the 116-DR-2 trench (Figure 2.1 of DOE/RL88-36 Rev.0 [DOE 1992a]) which is believed to be erroneous.

The basin's vertical walls and baffles were demolished in situ and the remaining walls and floor were stabilized with a minimum of $1 \mathrm{ft}$ of backfill. The fill dirt used to cover sludge within the basin during deactivation was obtained from the immediate vicinity of the basin. It is believed that some of the fill dirt was obtained from the sludge disposal trenches that were dug in 1953 (WHC 1991). It is not known if the entire contents of the sludge trenches were used as fill in the retention basin. The sludge trenches are located within the exclusion area fence. 
The site appears today as a large, vegetation-free, cobble-covered excavation with a central berm that runs the entire length. A portion of the steel effluent line remains exposed above ground; the exposed end has been backfilled with soil to limit access to the pipe interior. The entire area is surrounded by an 8-ft fence (which also encloses the 116-DR-9 retention basin) and is posted with Surface Contznination warning signs (Figure 4-14). The ground surface over the buried effluent line is surrounded by a steel post and light duty chain barrier that is posted as a Surface Contaminated Radiological Area. This area is about $100 \mathrm{ft}$ wide and 500 to $600 \mathrm{ft}$ long. It stretches from the fence surrounding the basin to the railroad tracks south of the basin and is covered by natural vegetation.

This waste site has an HRS Migration score of 76.91 (Stenner et al, 1988).

Figure 4-14. 116-D-7, 107-D Retention Basin, 1993.

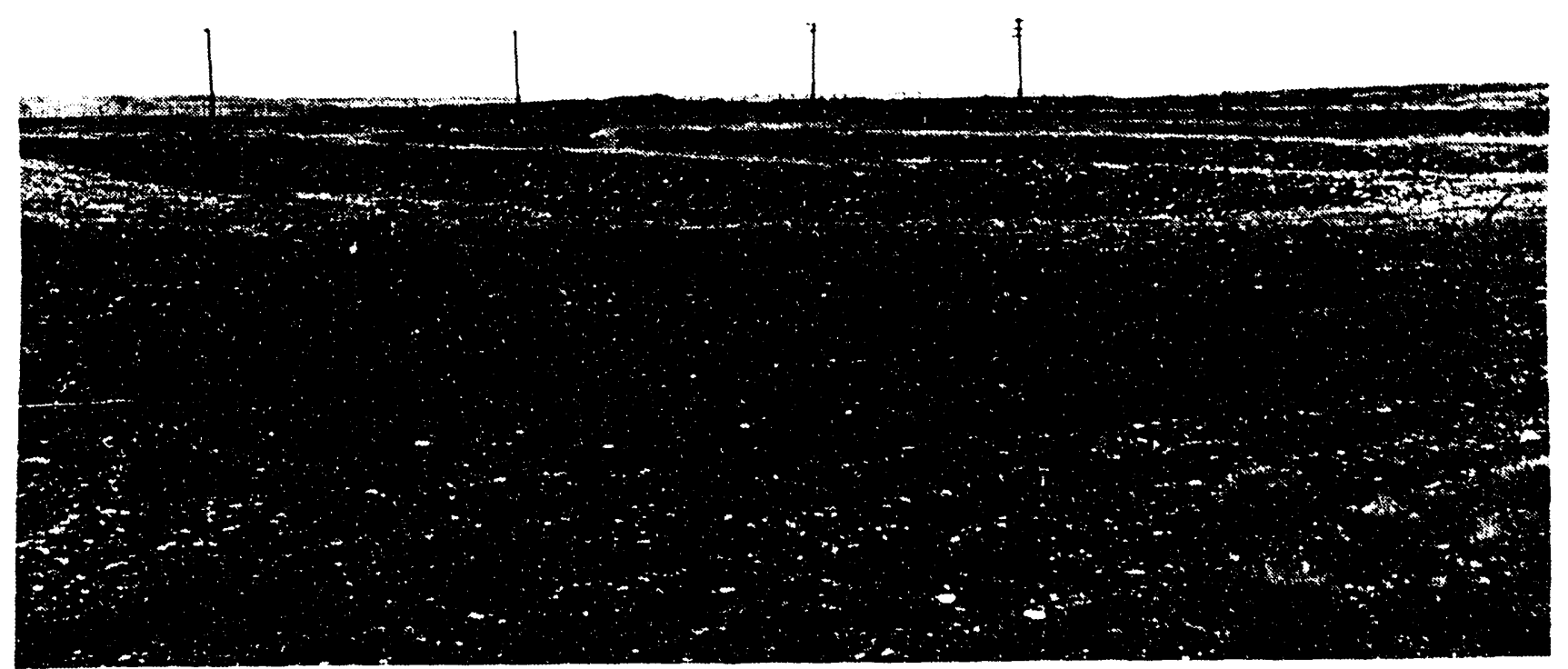

\subsection{6-D-9 (117-D SEAL PIT CRIB)}

The 116-D-9 crib is an inactive liquid waste site that operated from 1960 to 1967. It is located at Hanford coordinates N92053 W52532, which is about $200 \mathrm{ft}$ southeast of the 105-D Building. The crib is a 10- by 10- by 10-ftdeep gravel-filled crib with a large steel vent cap that extends above the ground surface. It received an estimated $420,000 \mathrm{~L}$ of drainage from the confinement system seal pits located in the 117-D Building (132-D-2). 
When this site was sampled in 1978, its contamination level was at or below background level. As a result of this sampling, the site was released from radiation zone status. No radiological inventory information could be found.

The site appears today as a vegetation-free, cobble-covered field with a large steel vent pipe extending above grade. There are no other markings or barriers unique to this site. The site is within a much larger area that is surrounded by permanent concrete markers and is posted with Underground Radioactive Material warning signs (Figure 4-15).

The 116-D-9 crib is a registered underground injection well (DOE 1988) and has an HRS Migration score of 0.00 (Stenner et al 1988).

Figure 4-15. 116-D-9, 117-D Seal Pit Crib, 1993.

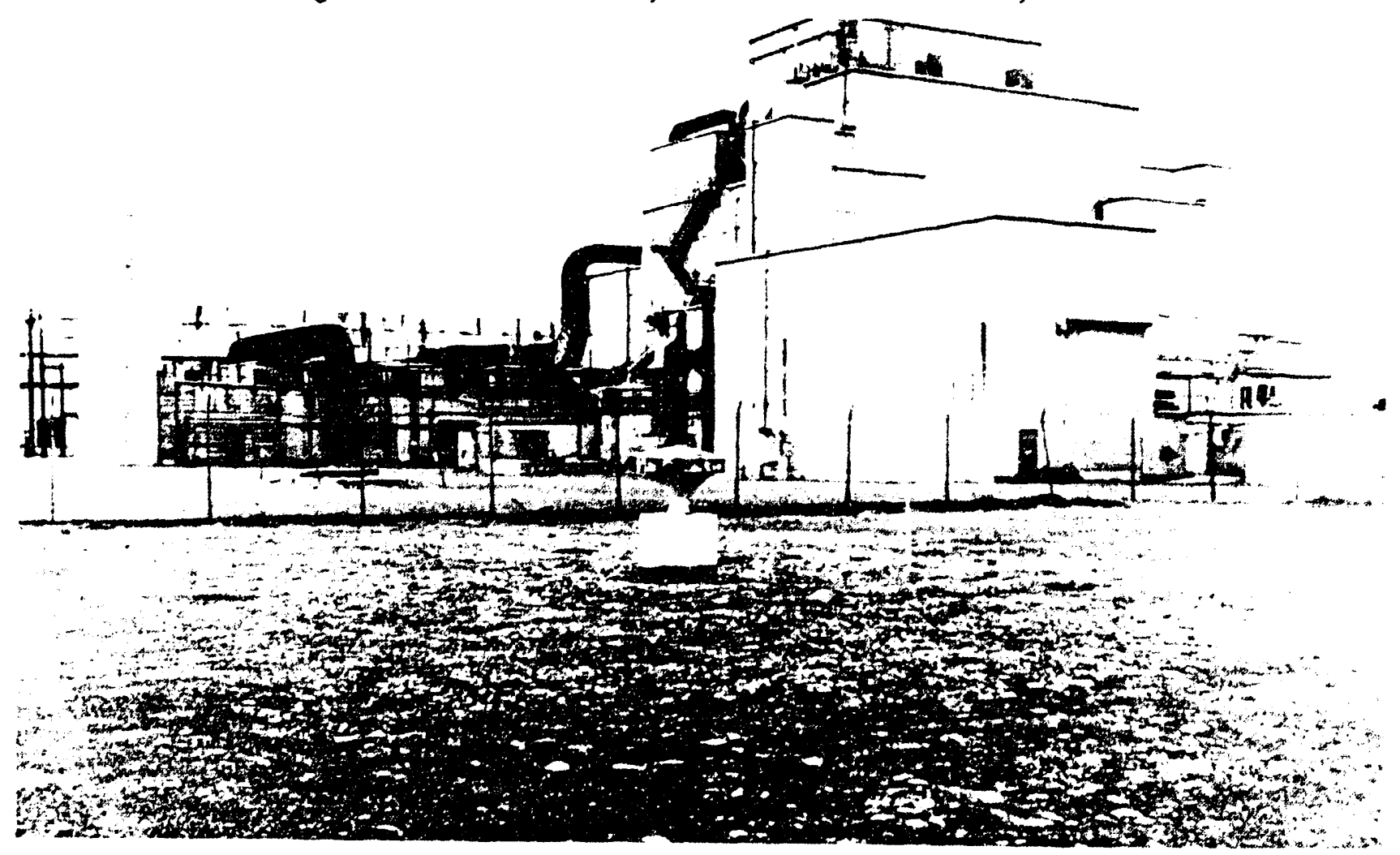

\subsection{6-D-10 (105-D FUEL STORAGE BASIN CLEANOUT PERCOLATION PIT)}

The 116-D-10 is an inactive liquid waste site that operated from July to September, 1984. It is located at Hanford coordinates N92325 W52225, which is about $150 \mathrm{~m}$ east of the 105-D Reactor Building and just outside of the HPSAC-5-40 permanent concrete markers (WHC 1991). The pits were also known as the 105-D fuel storage discharge ponds and the 105-D ponds. 
The ponds received processed water from the 105-D fuel storage bas in cleanout activities. The radiologically contaminated shielding water was processed through a process filter system using ion exchange columns, filters, and three 20,000-gal holding tanks. A total of 2,346,700 L was discharged to the 116-D-10 site (Miller and Steffes 1986).

The ponds consisted of two open, excavated pits with a crossover channel connecting them. The west excavation was 35 by 22 by $3 \mathrm{ft}$ deep. The small size of this original excavation only allowed for the discharge of one holding tank per day $(20,000$ gal). The east excavation was dug to increase the discharge capacity and was 50 by 24 by $4 \mathrm{ft}$ deep (Beckstrom 1985).

Before discharging processed water to the site, composite samples were taken to ensure that radionuclide concentrations were below release criteria in Table II of DOE Order 5480.1 (Miller and Steffes 1986). No known hazardous substances were present in the water. However, chemical analys is was not a standard practice at the time, and there is no evidence that one was performed. It should be noted that water removed from the 1608-D (132-D-3) is believed to be comparable to the fuel storage basin water, and extraction process for toxic metals testing (EP-TOX) results for the 1608-D water were negative.

On August 27, 1984, there was a process equipment failure that introduced very fine particles of sludge into the process water holdup tanks. When the "clean water" (as verified by radiochemical and isotopic analysis) from the holdup tanks was discharged, the fine sludge particulate was also discharged, significantly increasing the amount of radioactive material in the soil. Upon closure of the ponds, six dumptruck loads totalling $1,000 \mathrm{ft}^{3}$ of contaminated soil were removed from the site. After removal of the contaminated soil, a detailed survey using standard Hanford beta-gamma detection field instruments was performed.

Soil samples were also collected. Although residual concentration of contamination remained in the soil, it was below the unrestricted release level for dispersed activity requirements. Based on those results, the site was released and backfilled to grade with 3 to $4 \mathrm{ft}$ of clean soil (Beckstrom 1985).

There is no apparent visible evidence of the percolation pits at the site; it appears today as a cobble-covered field located outside the permanent concrete markers. Local natural vegetation (grasses, etc.) is beginning to reestablish itself in the area (Figure 4-16).

This waste site has not been assigned an HRS Migration score.

\subsection{6-DR-1 (107-DR LIQUID WASTE DISPOSAL TRENCH \#1)}

The 116-DR-1 trench operated from 1950 to 1967 (Stenner et al 1988). It is located at Hanford coordinates $\mathrm{N} 94650 \mathrm{W51900}$, which is $100 \mathrm{ft}$ east of the northeast corner of the 107-DR retention basin. The trench received an estimated 40,000,000 L of waste effluents from the 107-D (116-D-7) and 107-DR (116-DR-9) retention basins after outages due to ruptured fuel elements (Stenner et al 1988) (Figure 2-6). 
Figure 4-16. 100-D Fuel Storage Basin Cleanout Ponds.

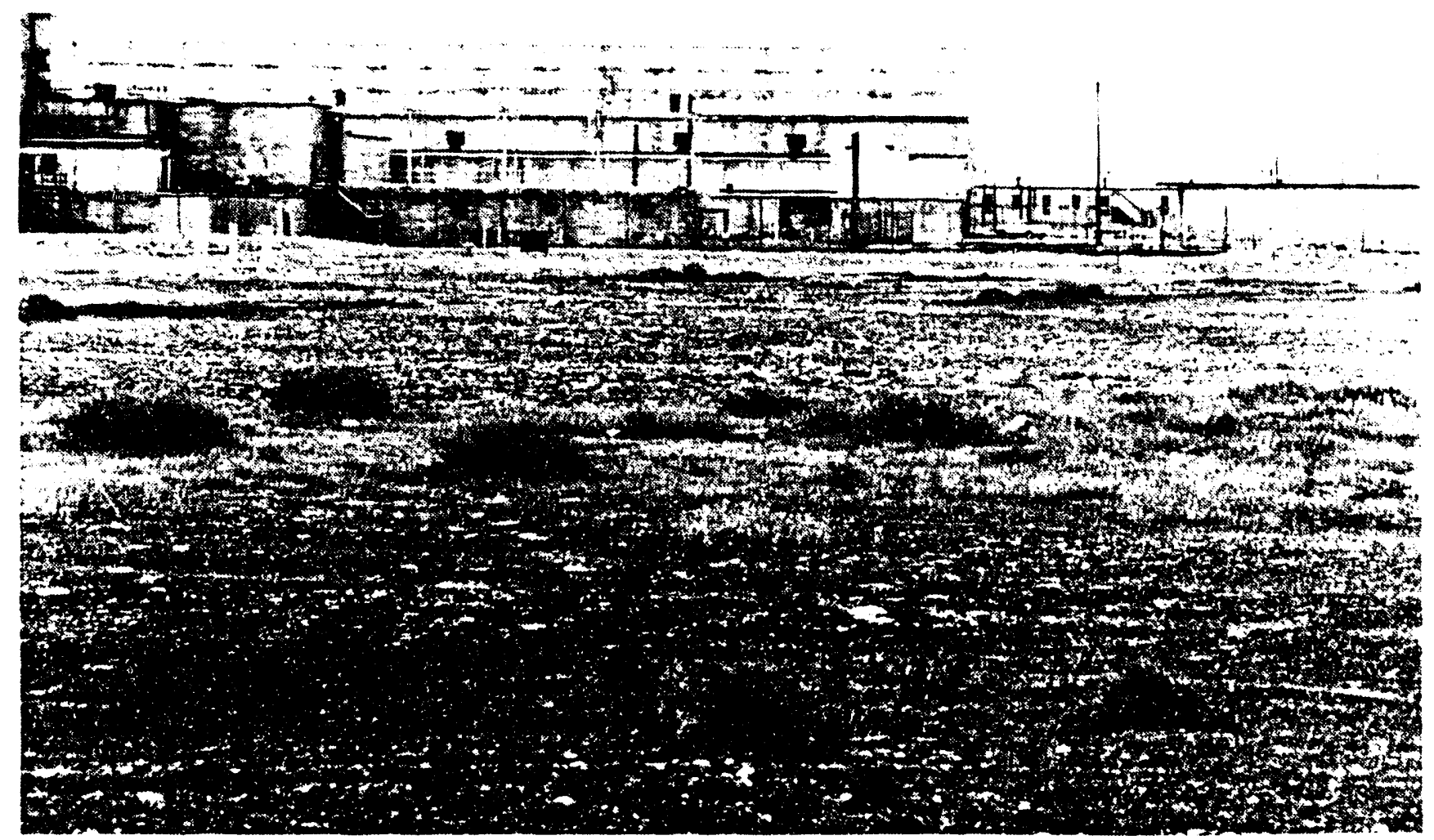

The radionuclide inventory in curies decayed through April 1, 1986 includes the following:

$\begin{array}{ll}{ }^{60} \mathrm{Co}: & 1.080 \mathrm{e}+000 \\ { }^{134} \mathrm{Cs}: & 2.250 \mathrm{e}-003 \\ { }^{137} \mathrm{Cs}: & 1.320 \mathrm{e}+001 \\ { }^{152} \mathrm{Eu}: & 5.390 \mathrm{e}+000\end{array}$

$$
\begin{array}{rl}
{ }^{154} \mathrm{Eu}: & 9.780 \mathrm{e}-001 \\
{ }^{155} \mathrm{Eu}: & 1.070 \mathrm{e}-001 \\
\mathrm{BH}^{3} \mathrm{H} & 4.470 \mathrm{e}-001 \\
{ }^{239} \mathrm{Pu}: & 3.150 \mathrm{e}-002
\end{array}
$$

$\begin{array}{rr}{ }^{240} \mathrm{pu}: & 3.500 \mathrm{e}-003 \\ { }^{90} \mathrm{Sr}: & 3.030 \mathrm{e}-001 \\ { }^{235} \mathrm{U}: & 2.400 \mathrm{e}-004 \\ { }^{238} \mathrm{U}: & 2.780 \mathrm{e}-002\end{array}$

(Stenner et al 1988)

In addition, the hazardous chemical inventory includes $40 \mathrm{~kg}$ of sodium dichromate (WHC 1991).

Effluent volume discharged to the trench was much greater than estimated by Stenner et al (1988). An additional estimated 102,240,000 gal/day for a period of four months was discharged to this trench (Eliason and Hajek 1967).

Originally the 300 - by 15 - by $20-\mathrm{ft}$-deep trench overflowed into 107-DR liquid waste trench \#2 (116-DR-2) via an underground pipe. It is believed that the 116-DR-1 was enlarged by removing the soil between the 116-DR-1 and the 116-DR-2 to create one large trench. This modification occurred sometime before 1967 and can be seen in Hanford Drawing M-1901-D, sheet 8 . 
Within the area shared with 116-DR-2, there was removable surface contamination that read up to $25,000 \mathrm{dpm}$ direct (using standard field instruments). This 50-ft area was covered with clean soil on March 27, 1989 (WHC 1991).

The 116-DR-1 appears today as a vegetation-free, cobble-covered field surrounded by permanent concrete markers and posted with Underground Radioactive Material warning signs. A terraced dirt mound located on the southeast for the revegetation constructed prior to 1987 as part of a feasibility study for the revegetation of burial grounds. It was terraced to determine the minimum soil depth required to sustain plant growth. Currently the 116-DR-1 and mound are treated with defoliants annually (Figure 4-17).

This waste site has an HRS Migration score of 42.32 (Stenner et al 1988).

Figure 4-17. 116-DR-1 and 116-DR-2, 107-DR Liquid Disposal Trenches.

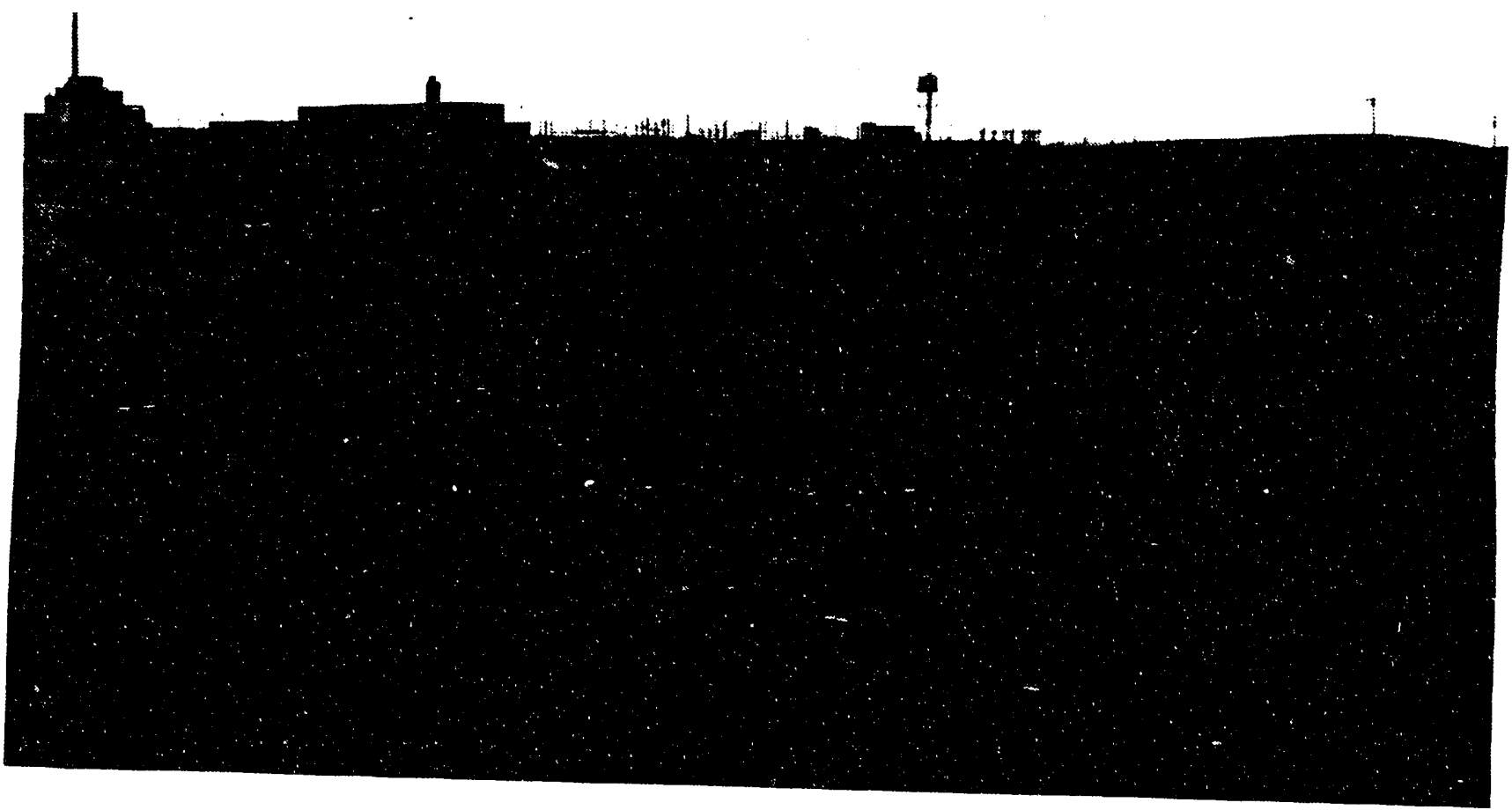




\subsection{6-DR-2 (107-DR LIQUID WASTE DISPOSAL TRENCH \#2)}

The 116-DR-2 trench is an inactive liquid waste site that reportedly operated from 1952 to 1967 (Stenner et al 1988), al though operations may not N94100 W52600, which is directly southeast located at Hanford coordinates trench \#1. The trench received southeast of the 107-DR liquid waste disposal effluents from the 116-DR-1 liquid waste dispo, 000,000 L of overflow activity due to fuel element failures. The radionuclide inventory in curies decayed through April 1, 1986
includes the following:

$$
\begin{array}{rrrr}
{ }^{60} \mathrm{Co}: & 1.080 \mathrm{e}+000 & { }^{154} \mathrm{Eu} & 9.780 \mathrm{e}-001 \\
{ }^{134} \mathrm{Cs}: & 2.250 \mathrm{e}-003 & { }^{155} \mathrm{Eu}: & 1.070 \mathrm{e}-001 \\
{ }^{137} \mathrm{Cs}: & 1.320 \mathrm{e}+001 & 3 \mathrm{H}: & 4.470 \mathrm{e}-001 \\
{ }^{152} \mathrm{Eu}: & 5.390 \mathrm{e}+000 & { }^{239} \mathrm{Pu}: & 3.150 \mathrm{e}-002
\end{array}
$$
dichromate (WHC 1991).
(Whardous chemical inventory includes $40 \mathrm{~kg}$ of sodium

The 150 - by 10 - by $20-\mathrm{ft}$-deep trench received overflow from the 116-DRuntil the soil between the two trenches was removed, creating one large trench. This modification occurred some time before 1967 and can be seen in
Hanford Drawing M-1901-D, sheet 8 .

Effluent volume discharged to this trench was much greater than estimated by Stenner et al (1988). An additional estimated 102,240,000 gal/day was 1967).

Within the area shared with 116-DR-1, there was removable surface contami nation that read up to $25,000 \mathrm{dpm}$ direct (using standard field instruments). perimeter is marked covered to grade with clean soil (WHC 1991). The ground Radioactive Material warningcrete markers and is posted with Underfree, cobble-covered field. There signs. It appears today as a vegetationsoutheast end of the site that is described fully in mound located on the

This waste site has an HRS Migration score of 42.32 (Stenner et al 1988).

\subsection{6-DR-5 (1904-DR OUTFALL STRUCTURE)}

The 116-DR-5 is an inactive liquid waste site that operated from 1956 to of the river bank about Hanford coordinates N94933 W53232, which is at the top retention basin (WHC 1991). 
The outfall was added as part of Project CG-558, which increased coolant flow through the reactor facilities and subsequently increased effluent flow to the river via the outfall structures.

Figure 20 of Trumble (1956) indicates several modifications to the effluent system that were a result of this project. This figure indicates that the outfall was fed by two 60-in steel pipes from the 107-DR (116-DR-9) retention basin via a weir that allowed effluent flow to be diverted to eitier or both of the 1904 outfall structures.

It appears likely that this outfall remained in operation until 1967. Photographs $t i{ }^{\prime}$ en after permanent closure of the 100-DR Reactor show that the $D$ and DR retencion basins were used in parallel and the outfall was probably used to discharge effluents until all reactor operations in the 100-D Area ceased.

The outfall structure was an open, reinforced, compartmentalized concrete water box (weir) that directed the effluent into a single $66-i n$. steel pipeline that extended to the river center bottom. This outfall pipeline passes through the approximate center of the small island north of the 100-D Area and ends approximately $1,850 \mathrm{ft}$ from shore. A reinforced concrete overflow spillway to the Columbia River shoreline was provided as part of the outfall structure in case the line became plugged (DOE 1992b) (Figure 4-18).

Figure 4-18. 116-DR-5, 1904-DR Outfal1, 1956.

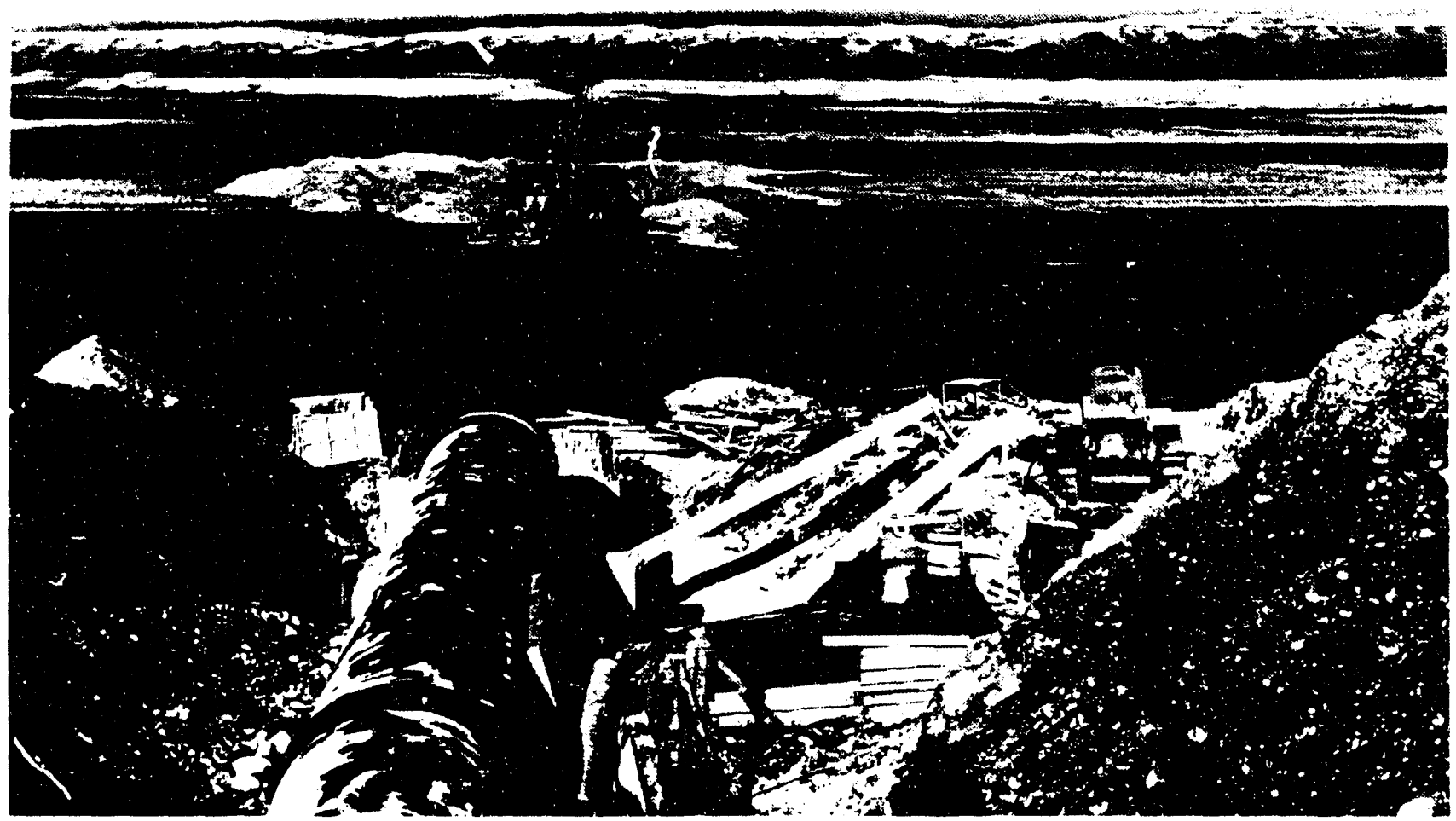


The outfall fence and aviary cover have been removed and the structure filled and covered with soil (WHC 1991). Portions of the outfall and spilliway remain exposed at the ground surface. In the northwest corner of the outfall structure there is a steel manhole cover that indicates a iarge underlying void when tapped on. It is assumed that this cover provides access to the effluent line to the river. A portion of the spillway at the riverbank remains exposed during periods of low water flow (Figures 4-19 and 4-20).

This waste site has not been assigned an HRS Migration score.

Figure 4-19. 116-DR-5, 1904-DR Outfa11, 1993.

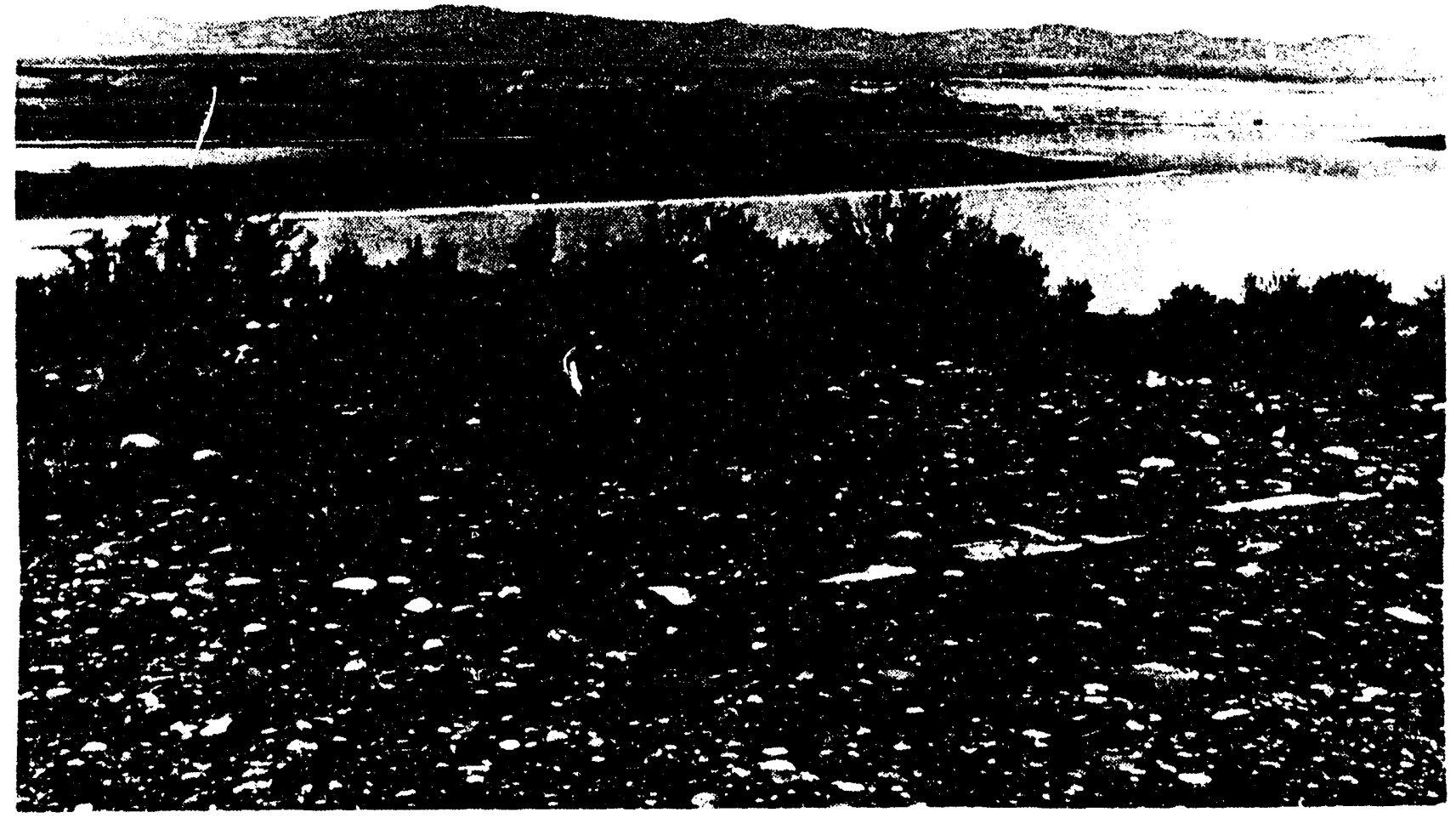

\subsection{6-DR-9 (107-DR RETENTION BASIN)}

The 116-DR-9 is an inactive liquid waste site that operated from 1950 to 1965 (WHC 1991). The basin remairied active as part of the 105-D Reactor effluent system until 1967 when the 105-DR Reactor was closed (Winship 1965). It is located at Hanford coordinates $N 94680$ W52516 (northwest corner), which is about 2,000 ft north of the 105-D Reactor Building (ERDA 1975).

The 600 - by 273 - by 20-ft-deep basin received reactor effluents from the 105-DR Reactor and later the 105-D Reactor (WHC 1991). It was an open, reinforced-concrete structure with a vertical concrete divider constructed lengthwise down the middle of the basin. The floor was constructed of concrete slabs, their joints originally closed with neoprene water seals. 
Figure 4-20. 116-DR-5, 1904-DR Outfall Flume, 1993.

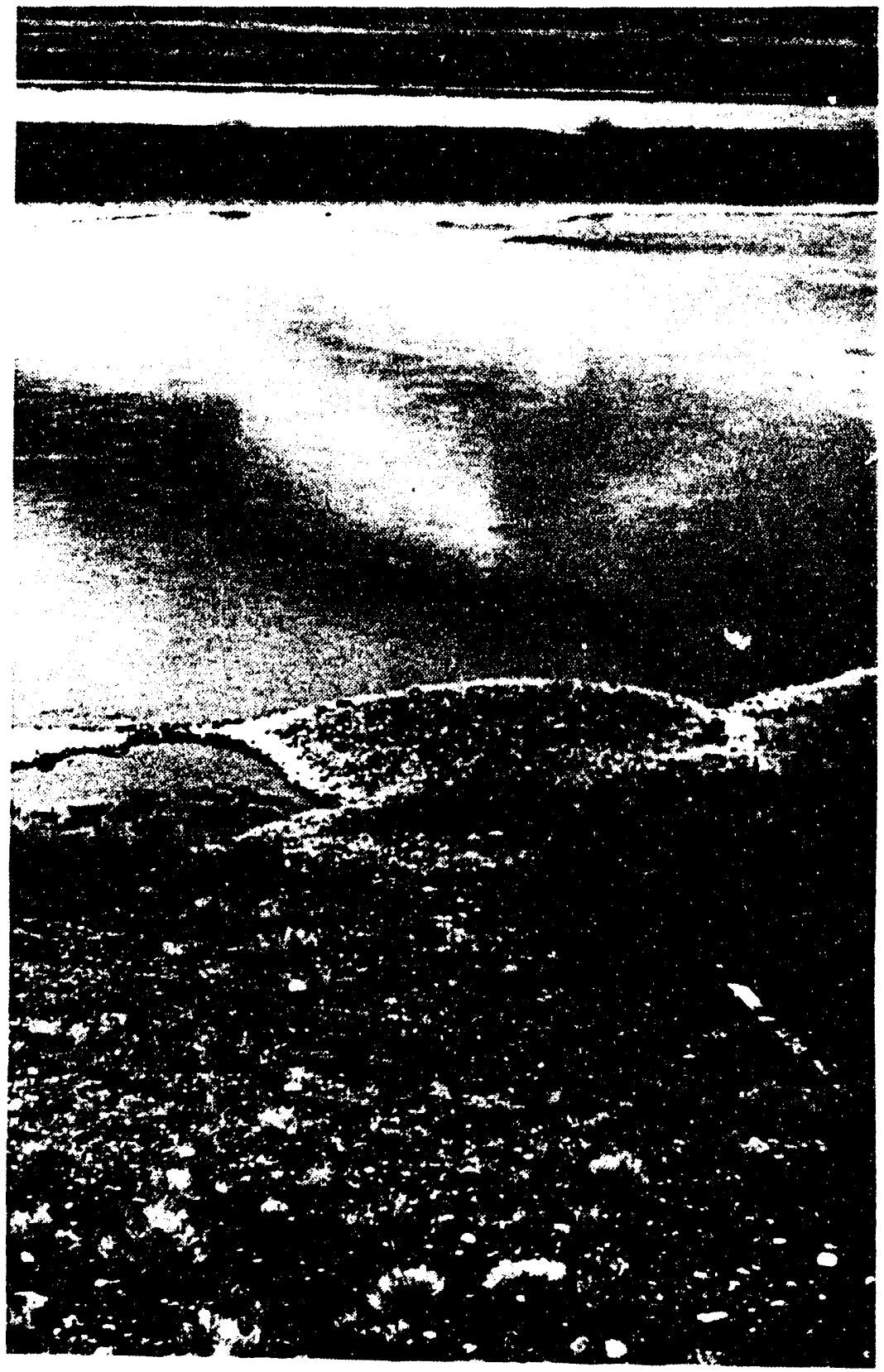

The walls sloped from the floor to a point $10 \mathrm{ft}$ above the floor level with the remaining wall (about $10 \mathrm{ft}$ ) being vertical. The sloping wall sections were 4 in. thick, and the vertical walls were reinforced concrete with a minimum thickness of $1 \mathrm{ft}$ at the top and $5.75 \mathrm{ft}$ at the bottom. Each side of the basin was divided into six sections, separated by baffle walls constructed of concrete and concrete blocks set on their sides. The purpose of these baffles was to slow and control channeling of the reactor cooling effluent water to maximize cooling and decay of short 1 ived radioisotopes prior to release to the Columbia River (Figures 4-21 and 4-22). 
Figure 4-21. 107-DR Retention Basin Construction.

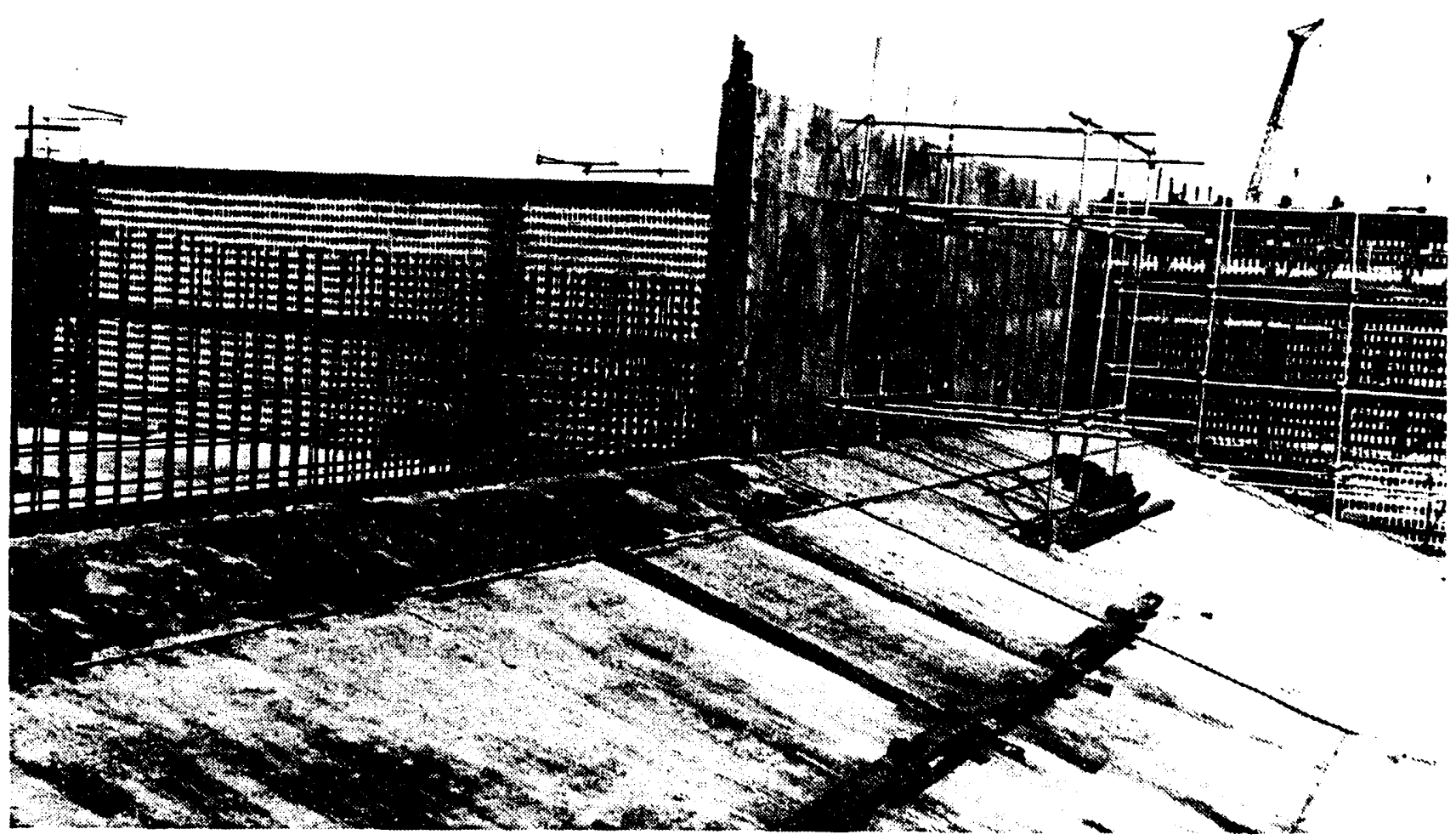

Figure 4-22. 107-DR Retention Basin Construction.

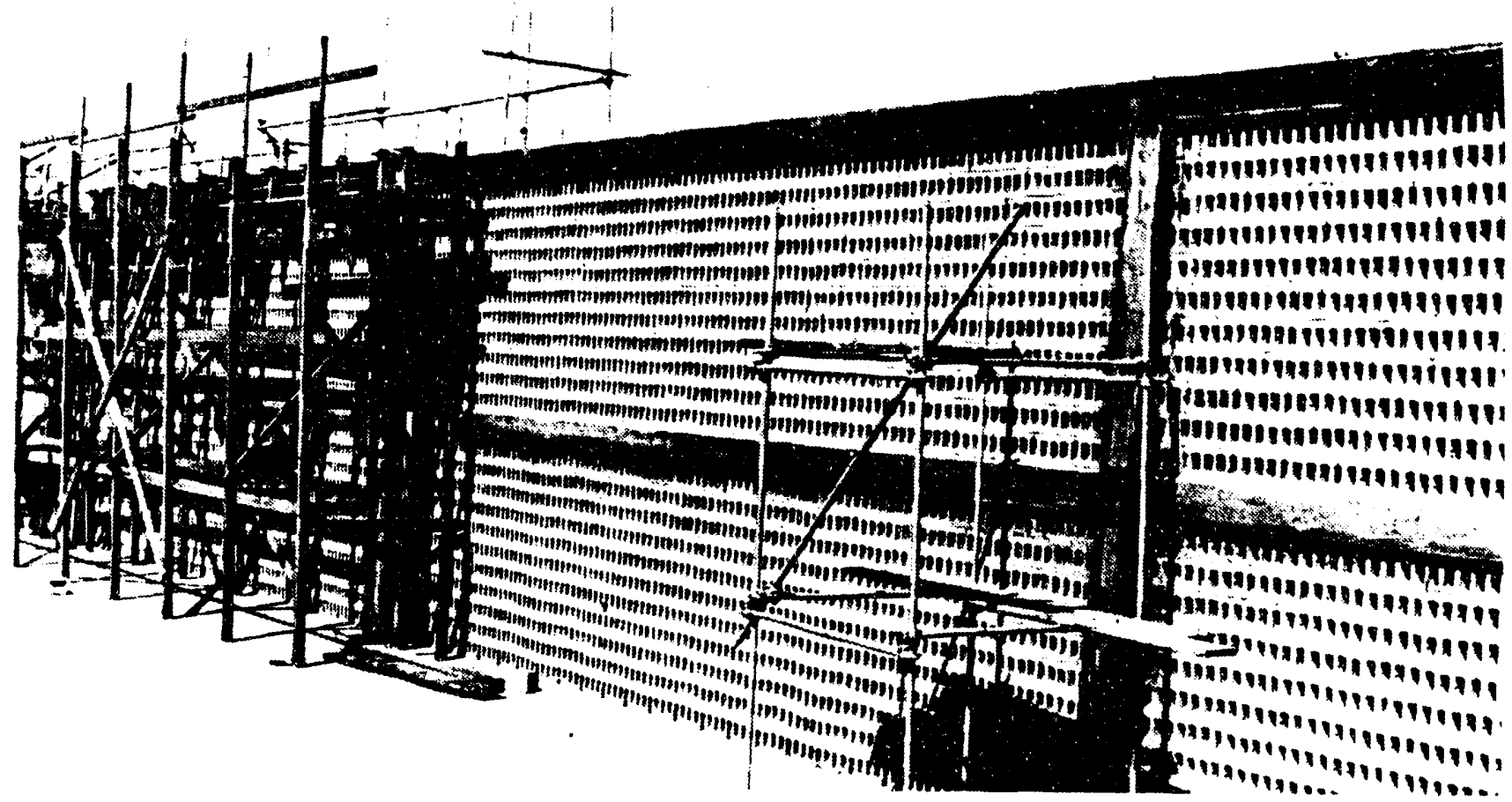


WHC-SD-EN-TI-181, Rev. 0

Total radionuclide inventories of samples taken in the vicinity of the basin ranged from 5 to over $400 \mathrm{Ci}$. Seventy percent of the total radionuclide inventory is contained in the soil adjacent to the basin. The remaining inventory (approximately $10 \mathrm{Ci}$ ) is contained in the demolished concrete walls and floor.

In late 1951, extensive leakage of effluent water, caused by the inlet pipes pulling loose from the basin wall, occurred at the inlet end of the basin (Rupert 1953) Readings of up to $100 \mathrm{mrad} / \mathrm{hr}$ were detected at the surface of the mud. Part of this contaminated soil was used in the fall of 1952 as backfill for the excavation around the anchor blocks south of the 107-DR basin. All contaminated soil was then covered by approximately two feet of soil. Most of the contaminated soil was not marked above ground in any way (Heid 1956).

During repair of the inlet leakage, a trench was dug from the inlet end towards the southeast corner to drain the area of effluent water. Upon completion of the job, the trench was backfilled with approximately four feet of soil. The area was unmarked above ground (Heid 1956).

A survey using a GM probe found that underground contamination from past leakage is greatest along the north wall of the basin and appears to be confined to within $25 \mathrm{ft}$ of the basin wall. Sampling beneath the basin indicated that the contamination is confined to within $3 \mathrm{ft}$ of the floor. As of 1978, the distribution chamber remained intact and contained approximately 1 in. of undisturbed basin sludge that was not covered by fill material (Dorian and Richards 1978).

Four sludge trenches were excavated in the 107-D and 107-DR Retention Basin area for the disposal of sludge that had accumulated at the bottom of the basins. The trenches were dug in the spring of 1953 to facilitate repair of the basins, by Minor Construction forces, and were covered after use by about 6 feet of soil (Dorian and Richards 1978). The location and pertinent information concerning these sludge disposal trenches can be found in section 4.8 of this document.

The walls and baffles have been demolished and disposed of in situ. They were stabilized with a minimum of 1 to $3 \mathrm{ft}$ of backfill material (Stenner et al 1988). Fill dirt used to cover the sludge within the basin was obtained from the immediate vicinity of the basin. It is believed that some of the fill dirt was obtained from the sludge disposal trenches (WHC 1991). It is unknown how much of this material was used as fill. The sludge trenches are currently within the exclusion area fence that surrounds both the $D$ and $D R$ retention basins.

The area appears today as a large, vegetation-free, cobble-covered excavation with a central berm running the entire length. It is surrounded by an 8-ft chain-link fence that encloses the 116-D-7 retention basin and is posted with Surface Contamination warning signs (Figure 4-23). A large area on the west side, outside the chain-link fence, is surrounded by a steel post and light chain barricade that is posted with Surface Contamination warning signs. This area begins at the south end and extends west of the basin to the steel post and light chain barricade surrounding the 107-D basin effluent line area. The ground surface is covered by natural vegetation of the area. 
Figure 4-23. 116-DR-9, 107-DR Retention Basin, 1993.

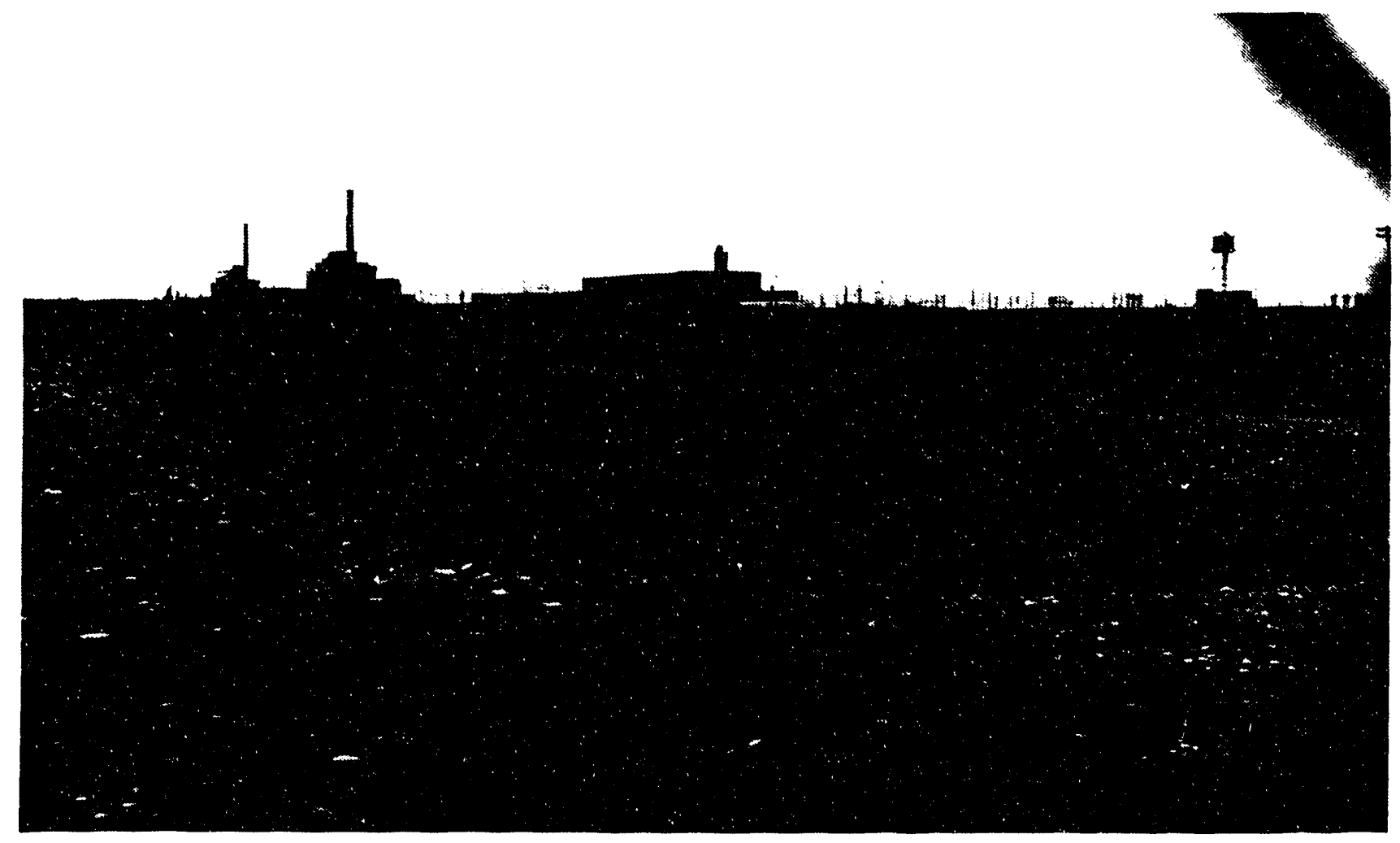

This waste site has an HRS Migration score of 76.91 (Stenner et al 1988).

\subsection{8-D-6 (105-D REACTOR BUILDING)}

The 118-D-6 is an inactive solid waste facility that operated from 1944 to 1967. It is located at Hanford coordinates $N 92200$ W52790, which is at the north end of the present exclusion area in the 100-D Area (WHC 1991).

The reactor building consists of the following:

- The reactor block, which includes the graphite moderator stack, biological and thermal shields, pressure tubes, and the safety control systems (horizontal and vertical control rods, Ball $3 X$ system, etc.)

- Irradiated fuel storage basin and decontamination wash pad

- Contaminated work and equipment rooms and areas of the reactor building

- Non-contaminated equipment, personnel, and control facilities.

The reactor facility contains an estimated $21,500 \mathrm{Ci}$ of radionuclides, 94 tons of lead, and $100 \mathrm{ft}^{3}$ of asbestos. Over $90 \%$ of the received radionuclide inventory is bound in activated metal and graphite (WHC 1991). These wastes are fixed inside the reactor envelope (biological shield). 
The fuel storage basin is known to have leaked for a number of years prior to deactivation. The leak rate was small, and the location of the leak was never identified (WHC 1991).

The water has been drained from the fuel storage basin, and extensive decontamination effort has been performed. The basin has been cleaned, and loose surface contamination has been fixed to the surface of the basin with ATCO Asphalt 1840 (trade name expired), an asphalt emulsion coating.

The facility appears much the same today as it did during operations (Figure 4-24).

This waste site has not been assigned an HRS Migration score.

Figure 4-24. 105-D.
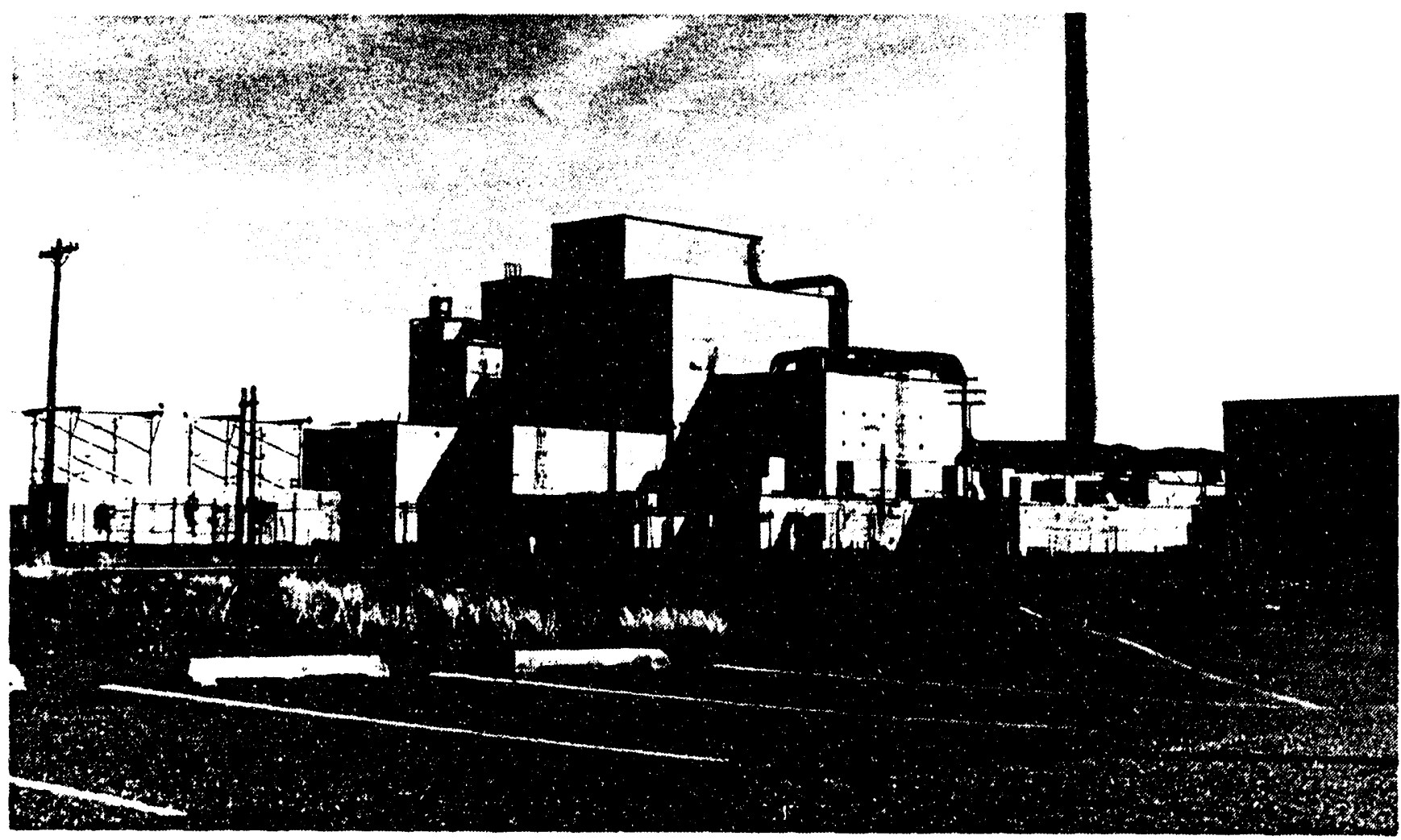

\subsection{0-D-1 (100-D PONDS)}

The 120-D-1 ponds are an active, nonhazardous, nonradioactive liquid waste site that has been in operation since January 1, 1977. They are located at Hanford coordinates $N 93800$ W53800, which is physically within the 100-D ash disposal basin (126-D-1) (WHC 1991). They occupy, approximately, the eastern half of the original ash pit (DOE 1992b).

In 1977 , a single pond was constructed by removal of the accumulated ash at the site to a depth of $9 \mathrm{~m}$ below grade. The excavated ash was deposited in piles (approximately 6 to $9 \mathrm{~m} \mathrm{high}$ ) around the perimeter of the excavation site, where it remains today. 
In 1979, the original pond was modified to eliminate a bottom sealing problem caused by the accumulation of flocculent. A dike was constructed within the pond to form two compartments: a settling basin and a percolation basin. A corrugated metal pipe extending through the dike served as the conduit between the two ponds.

The ponds receive 183-D sandfilter nonhazardous backwash that consists of alum-precipitated sand filter backflush. Previously, they also received chlorinated water from hydraulic test loops and fuel discharge trampoline testing facilities located within the 185-D/189-D Building.

The discharges from the test facilities included cooling water from heat exchangers and regeneration flushes from three demineralizer systems (Roos 1992). The recharge effluents (corrosive) from two of the demineralizer sources were released to the ponds once every two to three years and once every six years from the third system (WHC 1991).

The largest discharges have been nonradioactive, nonhazardous, nonregulated aqueous backwashes. Discharges from the demineralizer flushes, floor, and sink drains in the 185-D/189-D Facility may have been contaminated with hazardous materials (WHC 1991). Samples taken in 1992 indicate that there is mercury and PCB contamination above background levels (Appendix D, D-7).

The potential exists that the ponds received other hazardous wastes. The Mechanical Development Laboratory and associated shops located in 185/189-D used, designed, and built sophisticated machinery and used a variety of hazardous substances including paints, thinners, solvents, degreasers, and cleaning solvents. These substances could have been spilied or drained to the shop sewer and subsequently released to the ponds (Roos 1992).

Water samples collected in 1987 and 1988 from the percolation side of the pond indicated that no hazardous concentration of chemicals existed at that time (Jungfleisch 1988).

Ash from coal-fired power plants is known to be enriched in various trace elements. This raises concerns that hazardous chemicals may be present at the site as a result of the excavated ash or leaching from the surrounding ash piles. However, studies have shown that ash from power plants at the Hanford Site is nonradioactive and nonhazardous per the Washington Administrative Code (WAC) $173-303$.

The ponds have been modified. The corrugated steel pipe connecting the two ponds has been removed and is currently laying on the bottom of the percolation side of the ponds. Two steel overflow pipes have been added: the first, a 6-in. pipe, is at the approximate center and top of the dividing dike; the second, located closer to the east side of the ponds and also extending through the dike, is an 8 -in. schedule 40 steel pipe that is 2 to 3 $\mathrm{ft}$ below the dike top. There appears to be a valve in this pipe at the center of the dike. There is also 24-in. overflow riser located about 10 feet from the dike and $10 \mathrm{ft}$ from the pond inlet structure (concrete box). The riser has a closable steel cover that is partially open. The inlet structure is a $2-m$ ( $6 \mathrm{ft} 9$ in.) wide by 2-m (6 ft 9 in.) high box (DOE 1992b) that was a part of the 100-D Area process sewer system (Figure 4-25). 
Figure 4-25. 120-D-1, 100-D Area Ponds, 1993.

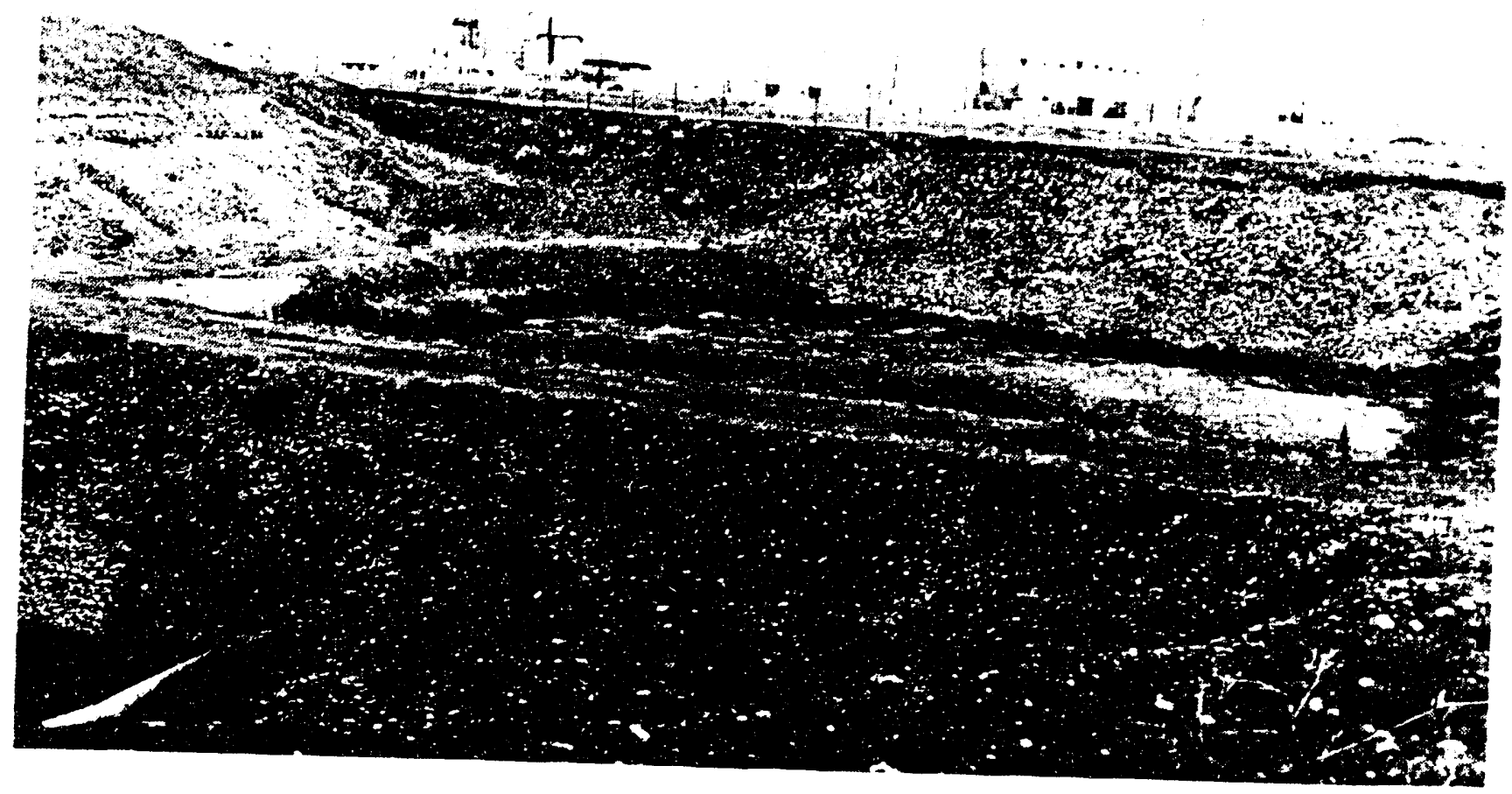

Since 1977, activities at the 100-D Area have diminished greatly; 185-D and 189-D are no longer used, and it is not anticipated that they wili ever reduced so much that water rarely flows from the ffluent to the ponds has been tion pond (Naiknimbalkar 1992).

This waste site has not been assigned an HRS Migration score.

\subsection{0-D-2 (186-D WASTE ACID RESERVOIR)}

The $120-D-2$ is an inactive nonradioactive solid waste site that was constructed for the disposal of waste acid from the 186-D Facility. It was
never used and was demolished in 1979 at Hanford coordinates $N 92170$ W53840 (nHC 1991). The reservoir was located west and south of the center of the 186-D Building.

The reservoir was 92.33 by 92.33 by $14 \mathrm{ft}$ deep and was constructed of "acid-proof brick, 3 ply waterproof membrane, vit pipe, \#8 lead flashing, and below grade level to the bottom. The reservoir were sloped $2: 1$ from $5 \mathrm{ft}$ 100-D Area process sewer system. 
The 186-D Building was originally constructed to be used as a water treatment plant but was never used as such. The waste acid reservoir was also never used for its intended purpose. No records have been found to document the storage or disposal of wastes of any kind in this facility. No written documentation has been found concerning the disposal of the lead flashing that was used in the construction of the waste acid reservoir; however, it is reported that the lead flashing was disposed in situ during the 1979 demolition of the 186-D Facility (Appendix D, D-11). The in situ disposal of this lead flashing is the cause of it's designation as a hazardous solid waste site.

A brick manhole at the site may have been associated with the structure (WHC 1991). This manhole may mark the location of a suspected sump for the waste acid reservoir. A 1992 site visit showed that soil materials in a caved-in portion of this manhole were discolored with yellow and blue stains (DOE 1992b).

The site currently appears as a cobble- and vegetation-covered field. A wood and steel post marker identifies the site (Figure 4-26). It could not be confirmed by documentation or drawings that the two brick manholes near the site were in any way associated with waste acid reservoir. There is a large square concrete structure with a metal cover nearby that is part of the 100-D Area process sewer system.

This waste site has not been assigned an HRS Migration score.

Figure 4-26. 186-D Waste Acid Basin.

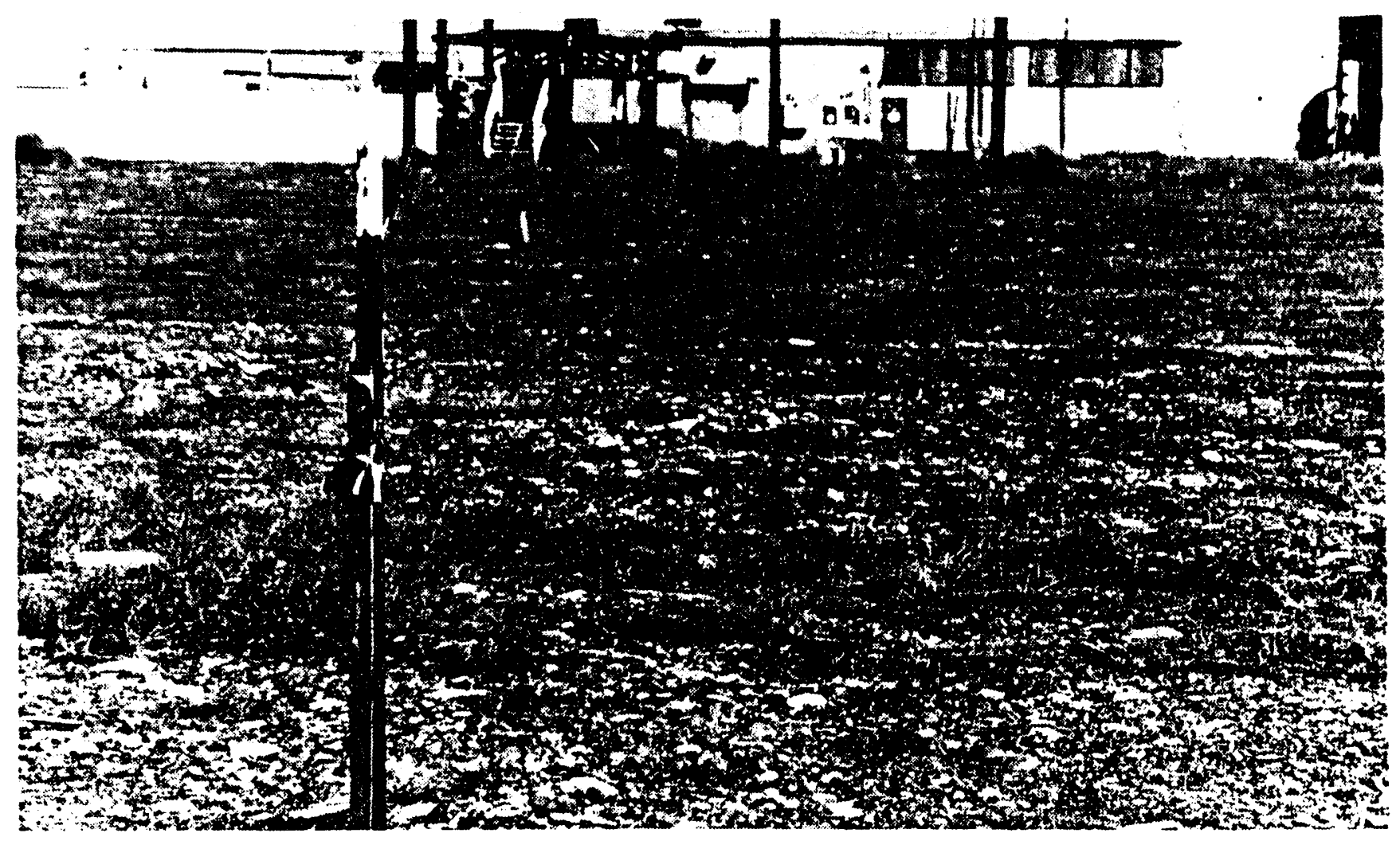




\subsection{6-D-1 (184-D POWERHOUSE ASH PIT)}

The 126-D-1 is an inactive, nonhazardous, nonradioactive solid waste disposal site that operated from 1950 to 1960. It is located at Hanford coordinates $\mathrm{N} 93900$ W53800, which is north of the 184-D Powerhouse and west of the 100-D ponds (120-D-1). This site is al so known as the 188-D ash disposal area and the 100-D ash disposal basin.

The site received an unknown amount of coal ash that was sluiced to the pits from the 184-D Powerhouse with raw river water. The ash has been determined by testing to be non-EP toxic in accordance with WAC 173-303 (WHC 1991).

The ash basin is no longer apparent and the entire area is covered by a large ash deposit about 6 to $9 \mathrm{~m}$ high. At the northwest end of the site there is an empty 55-gal drum standing near the pile. Weathering and rust have obliterated any identification of the drum's former contents, which it appears to have leaked. Very near the drum are sections of large steel grating. The ash piles are currently covered by grasses and other natural vegetation

(Figure 4-27).

This waste site has not been assigned an HRS Migration score.

Figure 4-27. 100-D Area Ash Disposal Basin Orphan 55-gal Drum.

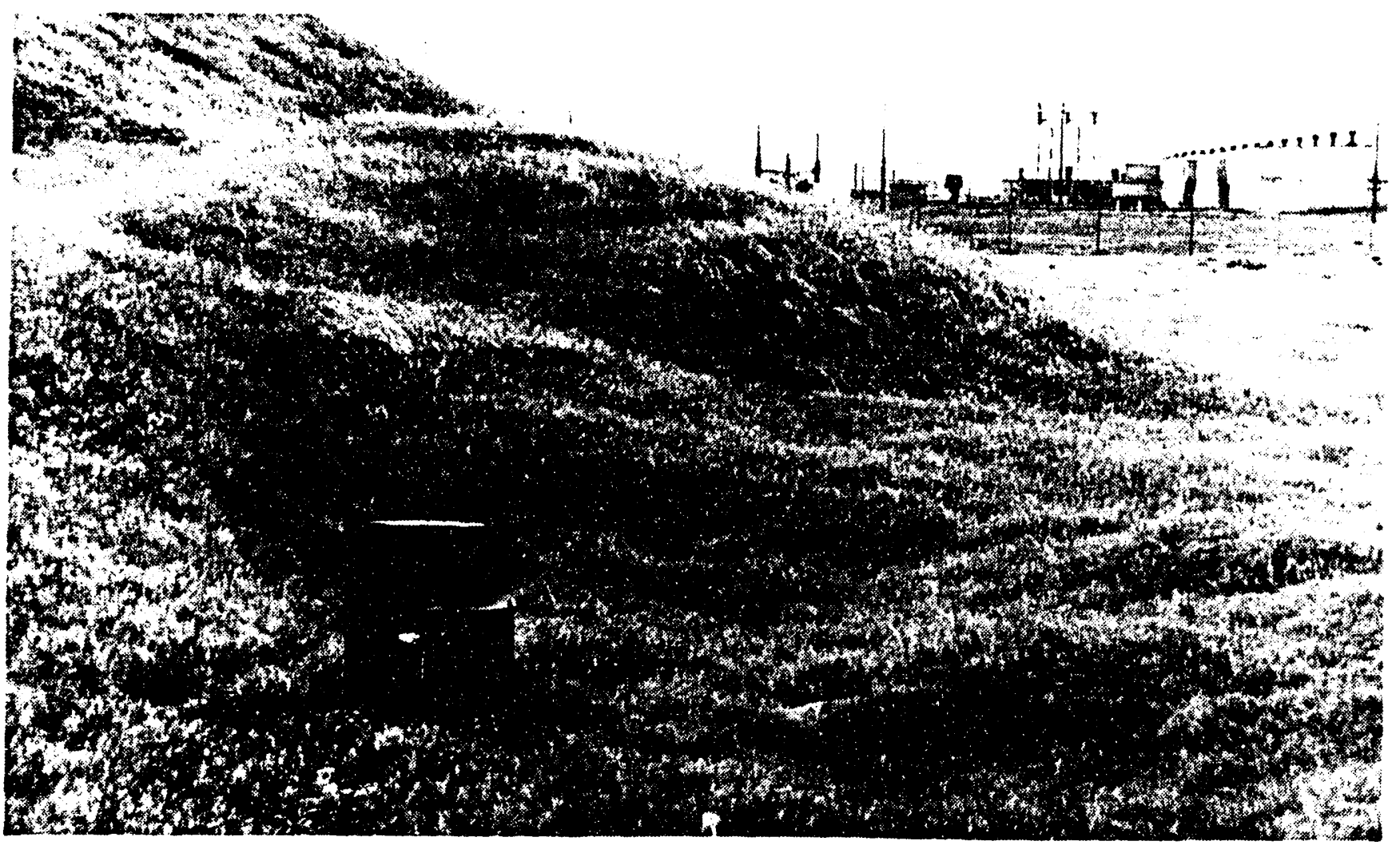




\subsection{6-D-2 (184-D COAL PIT)}

The 126-D-2 is an inactive, nonhazardous, nonradioactive solid waste site that was excavated in 1943 and operated as a burial ground from the 1970's to 1986. The coal pit is located at Hanford coordinates N93250 W54375, which is just west of the 184-D Powerhouse site and about $300 \mathrm{ft}$ north of the 183-D Water Treatment Facility.

Originally the coal pit was used to store coal for the powerhouse (Figure 4-28). Later it was used to receive solid wastes from demolition activities and demolished facilities such as the 184-D (including stacks), 108-D, released portions of the 115-D/DR, 186-D, and miscellaneous auxiliary building materials (roofing and transite siding).

Figure 4-28. 100-D Area, Coal Pit.

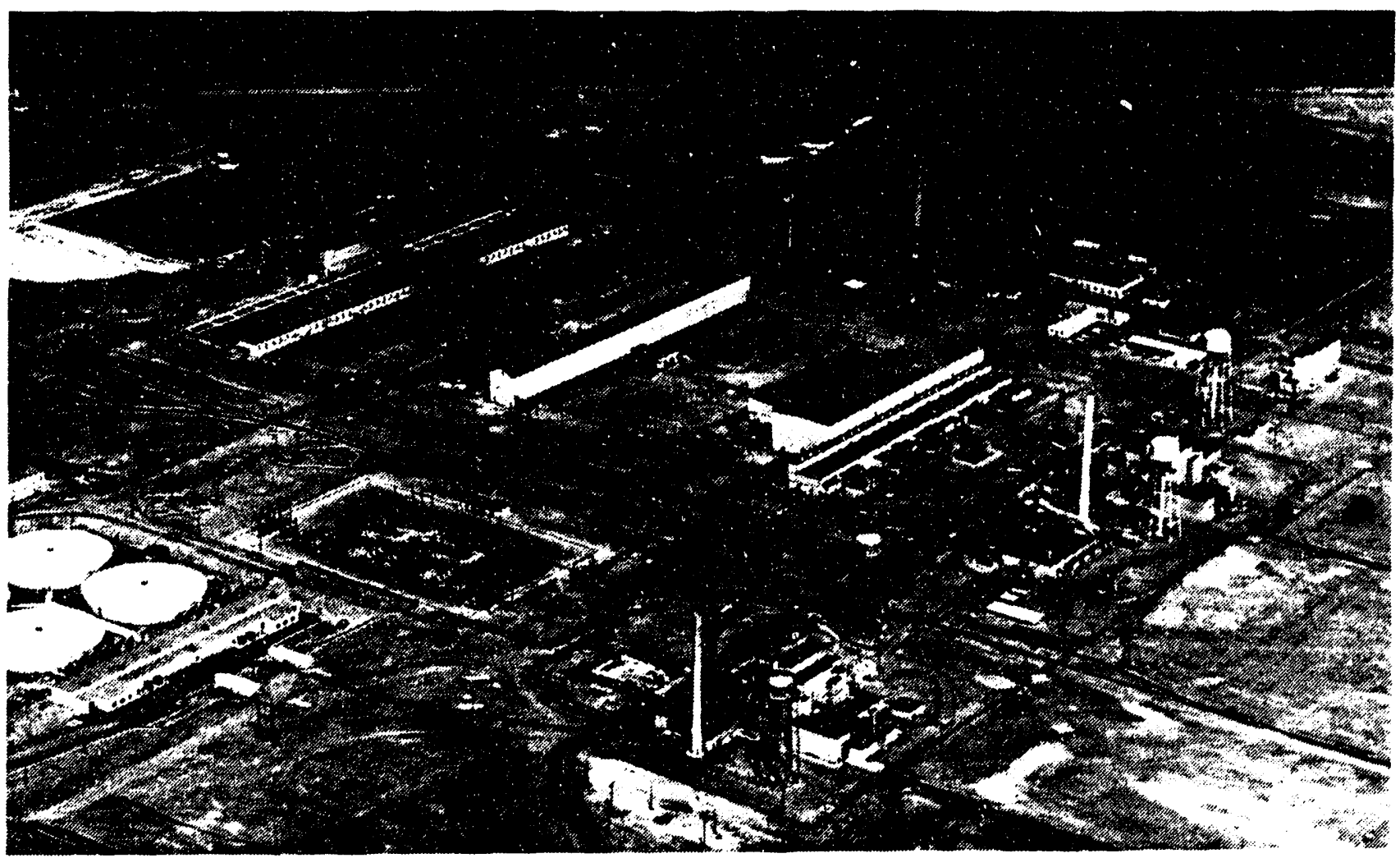

Of all the demolition and inert landfills in the areas, this one has the highest potential of containing hazardous wastes. It was active for many years and was known to have received solid wastes from the 185/189-D maintenance facilities, 100-N (WHC 1991), and other 100-Areas facilities. Conversations with site employees indicate that wastes from $100-\mathrm{N}$ included full and empty 5-gal paint cans, miscellaneous 1-gal paint cans, solvent cans, oil drums, wood, and other solid wastes (garbage). At least one flat bed truckload of full 5-gal paint cans are known to have been disposed of at this waste site. 
126-D-2 was used as an excess material dump for the 100-Areas for several years. Other wastes from 100-Area facilities included empty 55-gal acid drums, dry chemicals (suspect sodium dichromate crystals and others) which were spread on the ground prior to backfilling, batteries, photo chemicals, alum, creosote drums, 5-gal herbicide cans, carbon tetrachloride, methanol, acetone, radioactively contaminated materials and coveralls, welding materials including thorium electrodes, laboratory glassware, furniture, and other excess materials collected from decomissioned facilities.

There were several small acid fires at the site due to acid leaking from crushed drums and broken glass containers. No documentation could be found to substantiate these fires, but fire fighting personnel recalled at least one large fire at the location during the time period.

The coal pit also received tons of asbestos waste materials from the mid to late 1970's to the early 1980's. The asbestos wastes were bagged in plastic and transported to the site from various work sites throughout the 100 Areas for disposal.

In 1983 and 1984, paint cans (both spray and buckets), drums, and various types of garbage were found in and removed from this 1 andfill. At that time, about 80 percent of the pit was full and covered with backfill.

The backfill is about $1-\mathrm{ft}$-deep pit run material graded to conform to the natural terrain (WHC 1991). The backfill was also identified as being an asbestos looking material or an ash-like material that was tested by Dorian and Richards in 1978 and found to be non-hazardous (DOE 1992b). Conversation with site employees indicate that the ash deposited on the surface is wind blown material from the nearby powerhouse ash piles.

The 126-D-2 site appears today as a vacant field covered with an ash-like material and natural vegetation (grasses and annual weeds) (Figures 4-29 and 4-30).

This waste site has not been assigned an HRS score. 
WHC-SD-EN-TI-181, Rev. 0

Figure 4-29. 184-D Coal Pit, 1969.

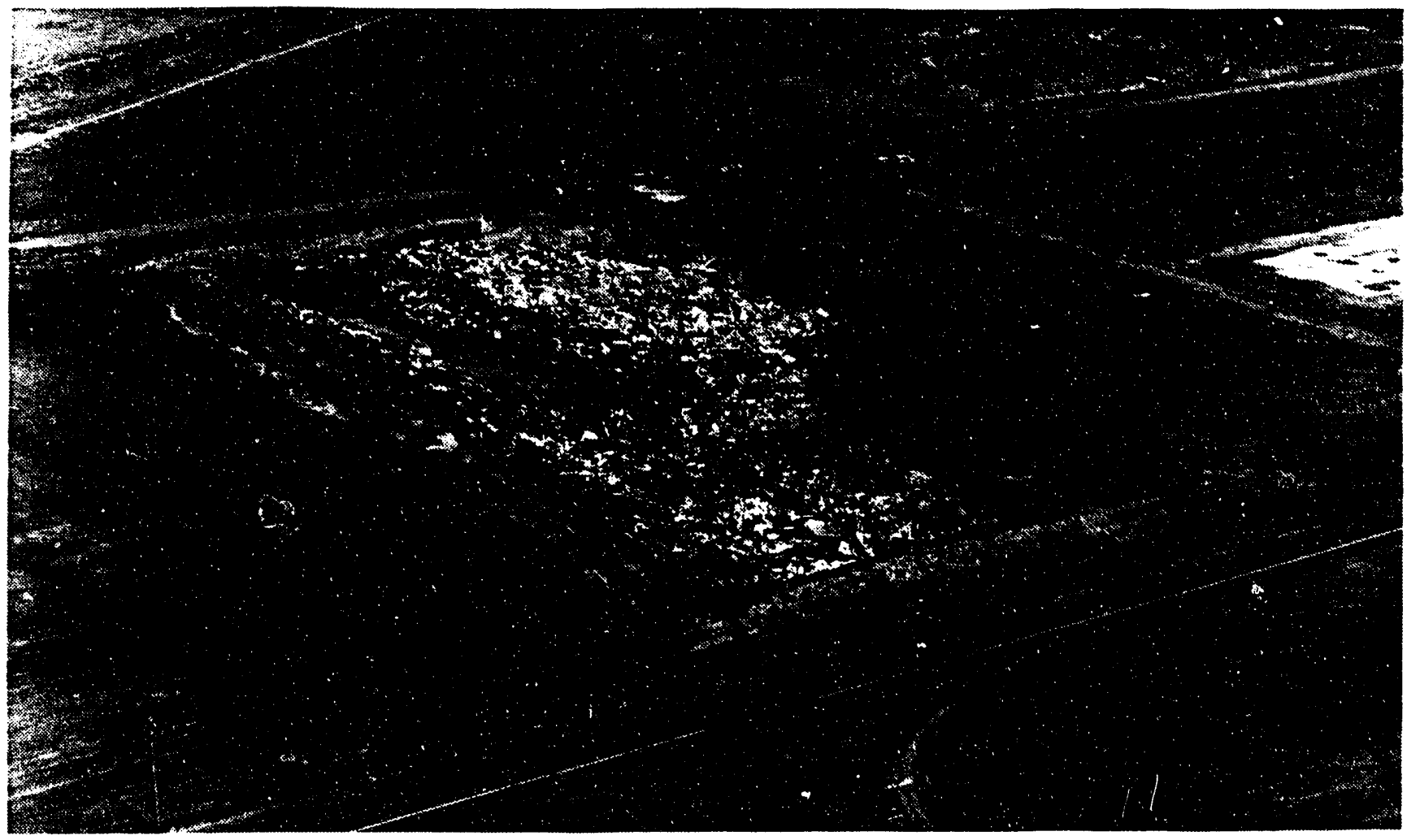

Figure 4-30. 194-D Coal Pit, 1993.

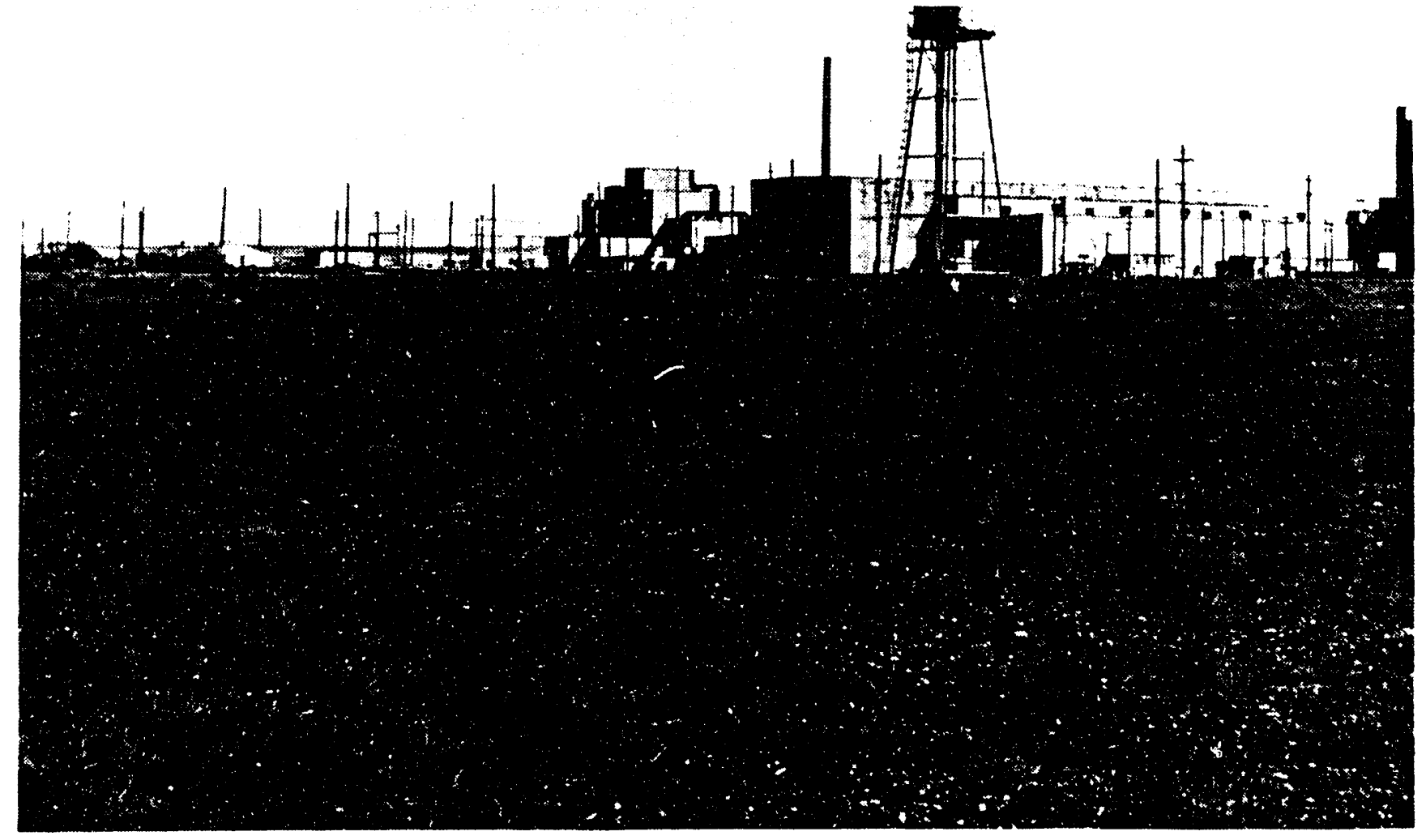




\subsection{6-D-3 (D-AREA BRINE AND SALT DILUTION PIT SITE)}

The 126-D-3 is an inactive solid waste site that ceased operation prior to 1980. The pits were located at Hanford coordinates $\mathrm{N} 93550 \mathrm{~W} 54050$, which is north of 184-D and just south of the railroad trarks.

The salt dissolving pit and brine pit were both below grade concrete vaults with internal void spaces (brine pit: $500 \mathrm{ft}^{3}$; dissolving pit: 900 $\mathrm{ft}^{3}$ ). The salt and brine solution was used to regenerate the zeolite ion exchange demineralizers that were a part of the treatment of water used for steam generation.

Both pits were sampled for radiation and EP toxic metals. Samples showed the $\mathrm{NaCl}$ ( $\mathrm{sal} t$ ) concentrations were greater thai the 10\% hazardous material limit. No significant radioactive materials were found. Northwest Environmental Services, Inc. removed all liquid hazardous waste (4,100 gal) and salt cake $\left(8.3 \mathrm{yd}^{3}\right)$ from the pits and certified them clean before in situ demolition and final grading in March 1988. The pits were partially backfilled with rubble and leveled to grade with clean fill (Griffin 1988).

The current appearance is that of a cobble-covered field. There is evidence of heavy equipment activity at the site. Nearby to the east there is a soil subsidence that contains concrete and steel grating debris (Figures 4-

Figure 4-31. Salt and Brine Pit.

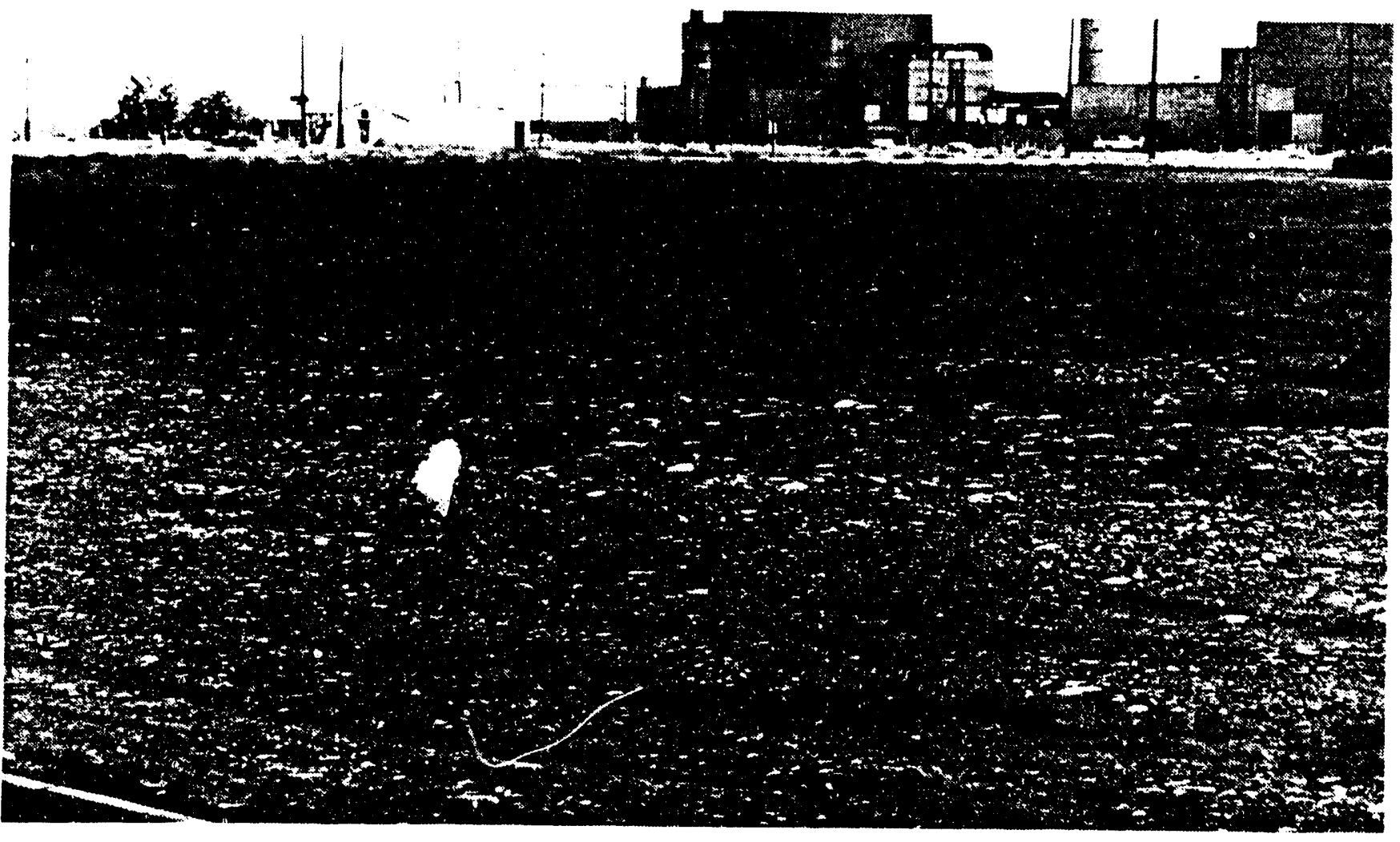


Figure 4-32. Subsidence Near Salt and Brine Pit.

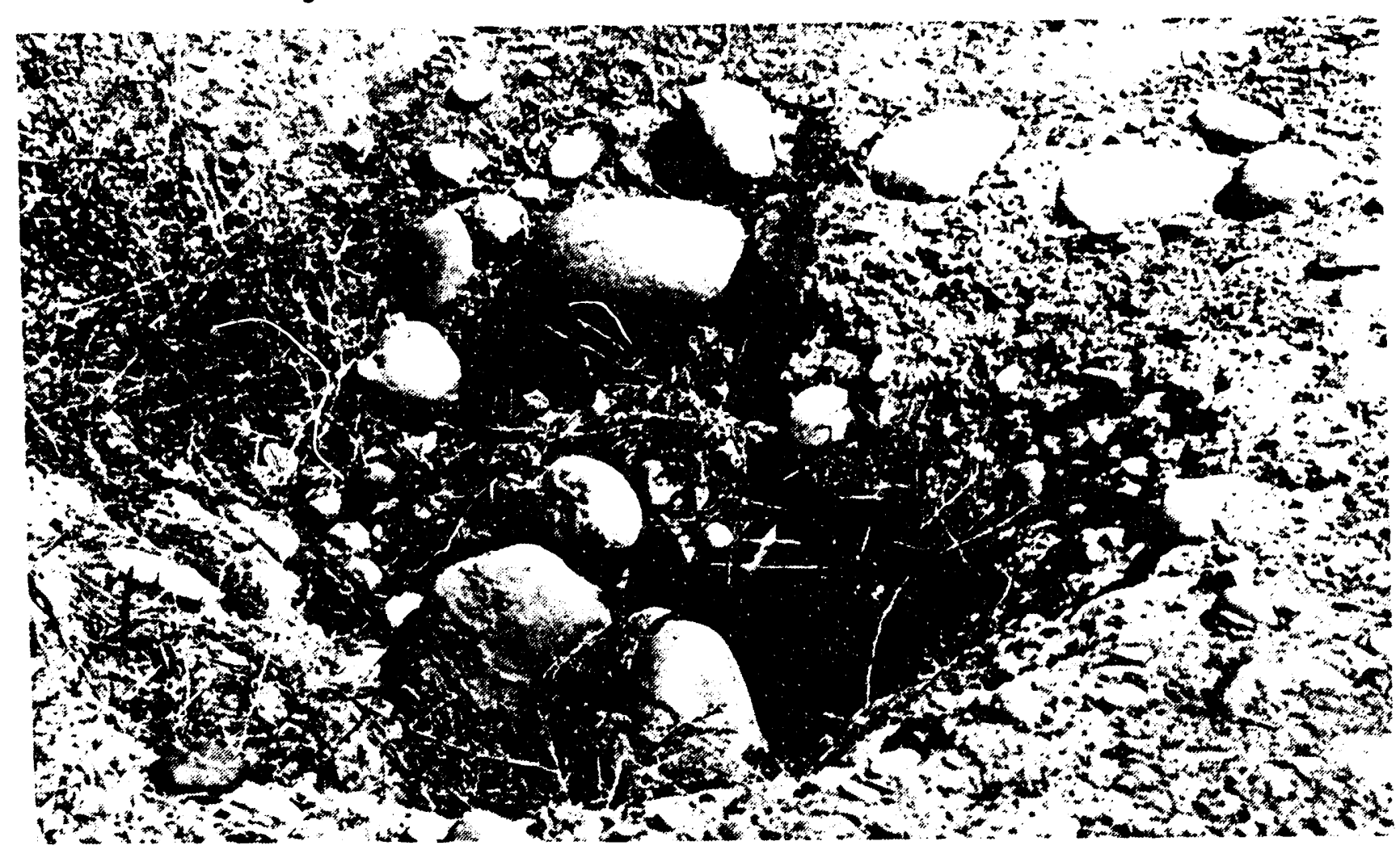

This waste site has not been assigned an HRS Migration score.

\subsection{8-D-2 (BURN PIT)}

The 128-D-2 is an inactive solid waste site that is located at Hanford coordinates $\mathrm{N} 93280 \mathrm{~W} 50900$, which is about $600 \mathrm{ft}$ northeast of the 128-D-1 burn pit. It is a large landfill area (240 by $240 \mathrm{ft}$ ) with evidence of surface burning. It has no definite boundaries but is marked with signs of plant stress, depressions, and berms. Pieces of reactor hardware and non-contaminated graphite blocks were found at the site (WHC 1991).

Concrete and metallic debris exposed on the surface just north of the area indicate possible buried solid wastes. The site appears to have been built up with backfill material, although it is difficult to tell where the burn area ends and the burial area begins. The site is currently being used as a disposal area for tumble weeds (Figure 4-33).

This waste site has not been assigned an HRS Migration score. 
Figure 4-33. 128-D-2, Burn Pit, 1993.

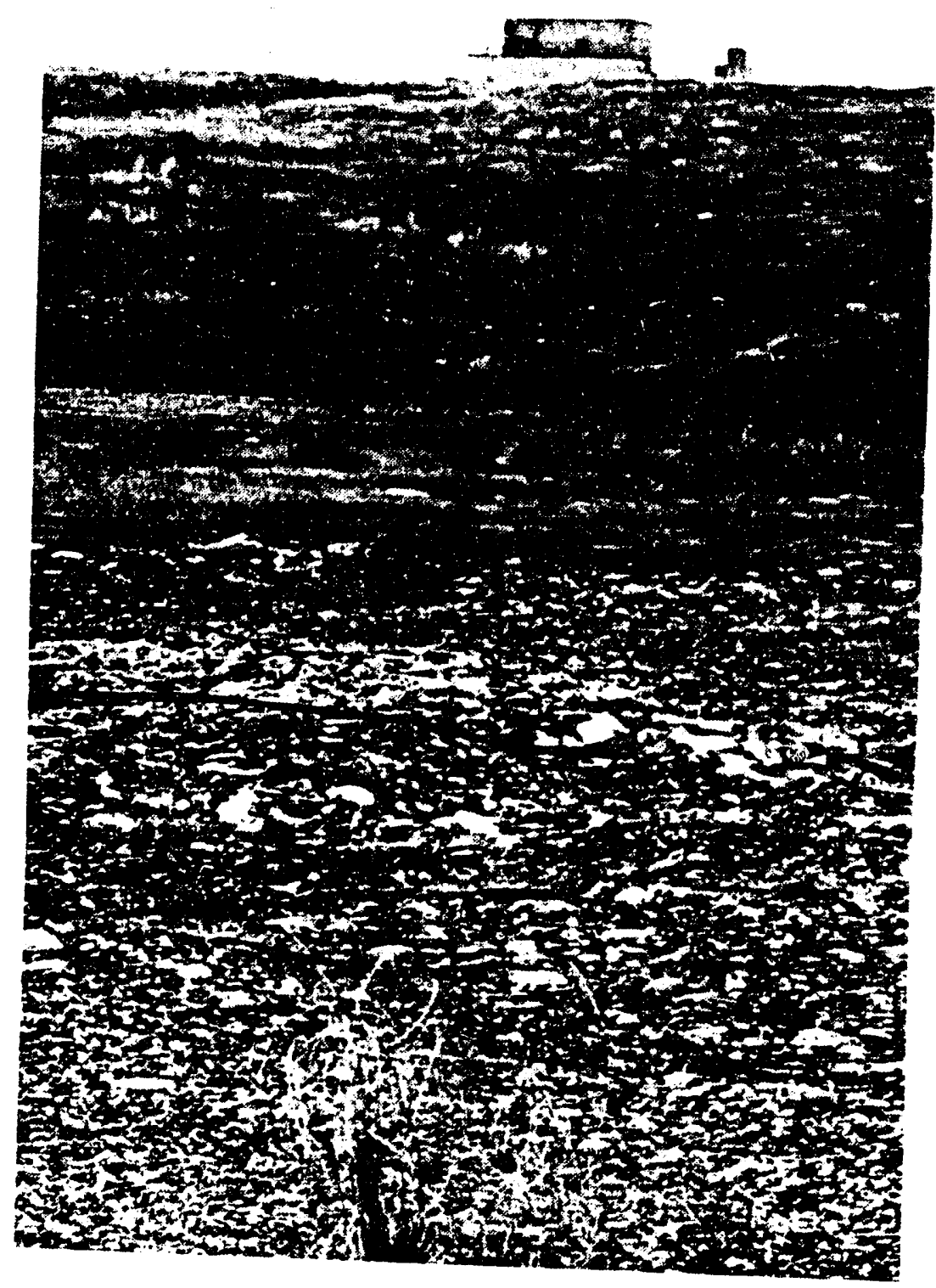

\subsection{0-D-1 (1716-D GASOLINE STORAGE TANK SITE)}

The $130-D-1$ is an inactive nonhazardous, nonradioactive liquid waste site N92880 W53920 (WHC 1991). It was The tank was located at Hanford coordinates port of the garage and gas dispensing operation. 1989. It was also known as the 1706-0 gasolion. The tank was removed in 
When the garage and gas dispensing operation was centralized following the deactivation of the 100-D Area, the tank was emptied of gasoline and filled with water. The capacity of the underground steel tank was 15,140 L $(4,000 \mathrm{gal})$.

At the time of removal, the tank was in very poor condition and had leaked its entire contents. The soil beneath the tank was black and had an organic/gasoline odor (Roos 1989). The results of the samples taken from the bottom of the excavation can be seen in Table 4-6.

Table 4-6. HEHF Soil Sampling Results.

\begin{tabular}{|c|c|}
\hline SAMPLE * & $\begin{array}{c}\text { PETROLEUM } \\
\text { HYDROCARBONATE }\end{array}$ \\
\hline D109 & 83.80 \\
\hline D110 & 69.80 \\
\hline D111 & 69.80 \\
\hline D112 & 1128.00 \\
\hline D113 & $<50.00$ \\
\hline D114 & 7430.00 \\
\hline D115 & 279.00 \\
\hline D117 & 293.00 \\
\hline (Hami1ton 1989)
\end{tabular}

The site was backfilled with clean soil; no cleanup activities were performed prior to backfilling.

The current appearance is that of a cobble-covered field. There is a recently placed concrete marker with a brass identification medalition embedded in the surface at the location (Figure 4-34).

This waste site has not been assigned an HRS Migration score.

\subsection{2-D-1 (115-D/DR GAS RECIRCULATING FACILITY SITE)}

132-D-1 is an inactive solid waste site that operated from 1944 to 1967. The facility was located at Hanford coordinates N92012 W52727, which is about $150 \mathrm{ft}$ south of the 105-D Reactor Building. It was demolished in situ during 1986.

The facility was constructed in 1943 with equipment for the 105-D Reactor. The equipment for the 105-DR Reactor was added in 1947 and placed in operation in 1950 (Griffin 1987). 
Figure 4-34. 100-D Gasoline Tank Site.

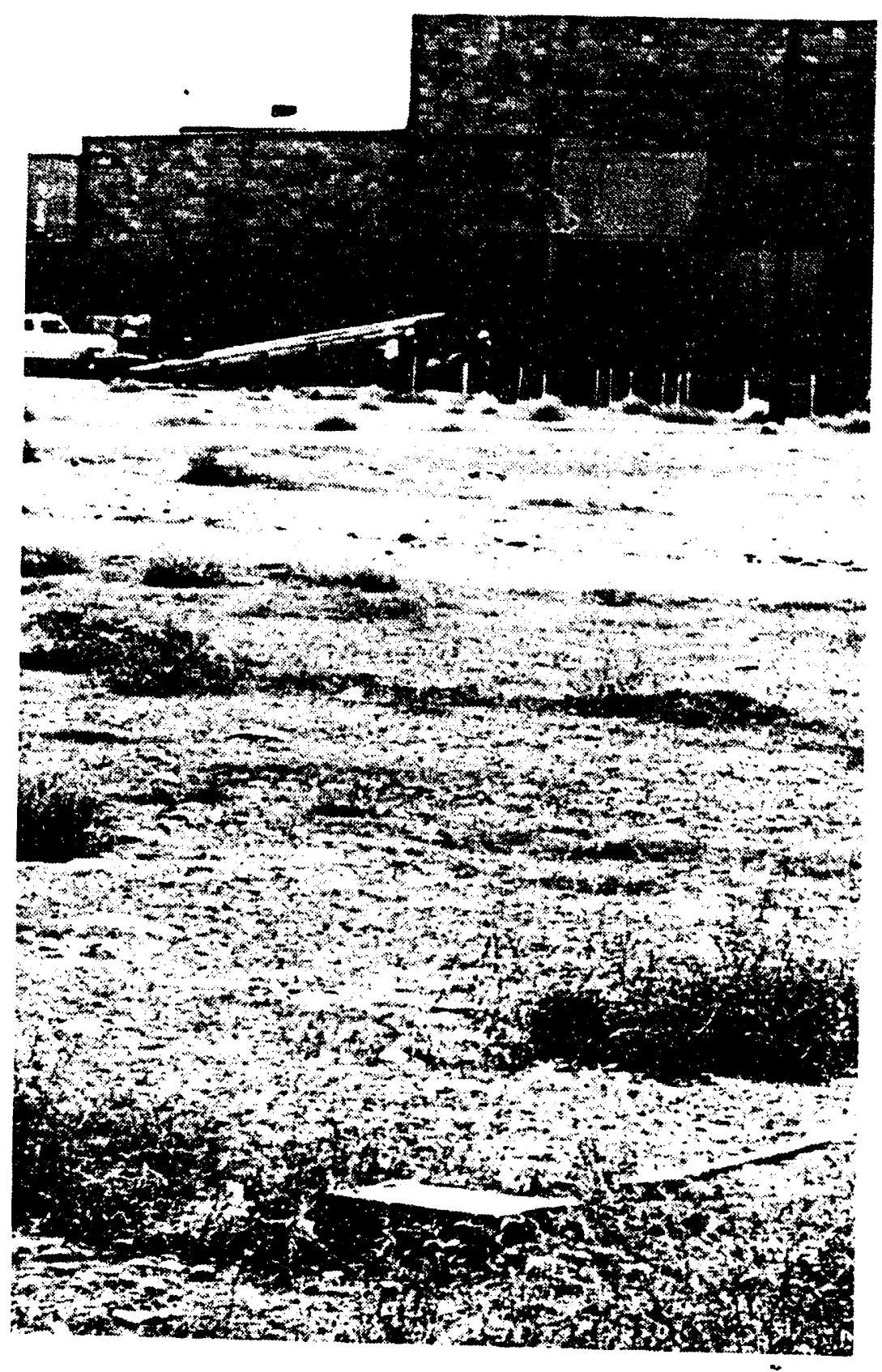

The 168- by 98- by 20-ft facility was used to recirculate, filter, dry, and inject the gases (helium and carbon dioxide) used as a cover gas for the 105-D and 105-DR Reactor cores. It was a one-story reinforced concrete structure with a basement that consisted of the building cells, vacuum and pressure seal pit, and tunnels. At ground level, an operating gallery ran the length of the building and was flanked on either side by cells that contained the gas processing equipment. The cells (including walls, ceilings, and floors) were constructed of reinforced concrete slabs with composition surfaces. 
At right angles to the operating gallery and extending across the full width of the building's end was the fan room, constructed of concrete block. It contained the ventilation fan, air compressor, office, and locker room (WHC 1991). At each end of the basement level a tunnel contained the 16-in. gas recirculating piping to the reactors. The tunnels were $12 \mathrm{ft}$ wide by $6.5 \mathrm{ft}$ high for 105-D and $5 \mathrm{ft}$ wide by $6.5 \mathrm{ft}$ high for 105-DR, narrowing to $4 \mathrm{ft}$ wide before entering the 115-D/DR Building (Griffin 1987). Connected to and part of the 105-D tunnel was the vacuum and seal pit and a portion of the 1608-D lift station (Figure 4-35).

Figure 4-35. Septic Tank Surrounded by White Fence, 1953.

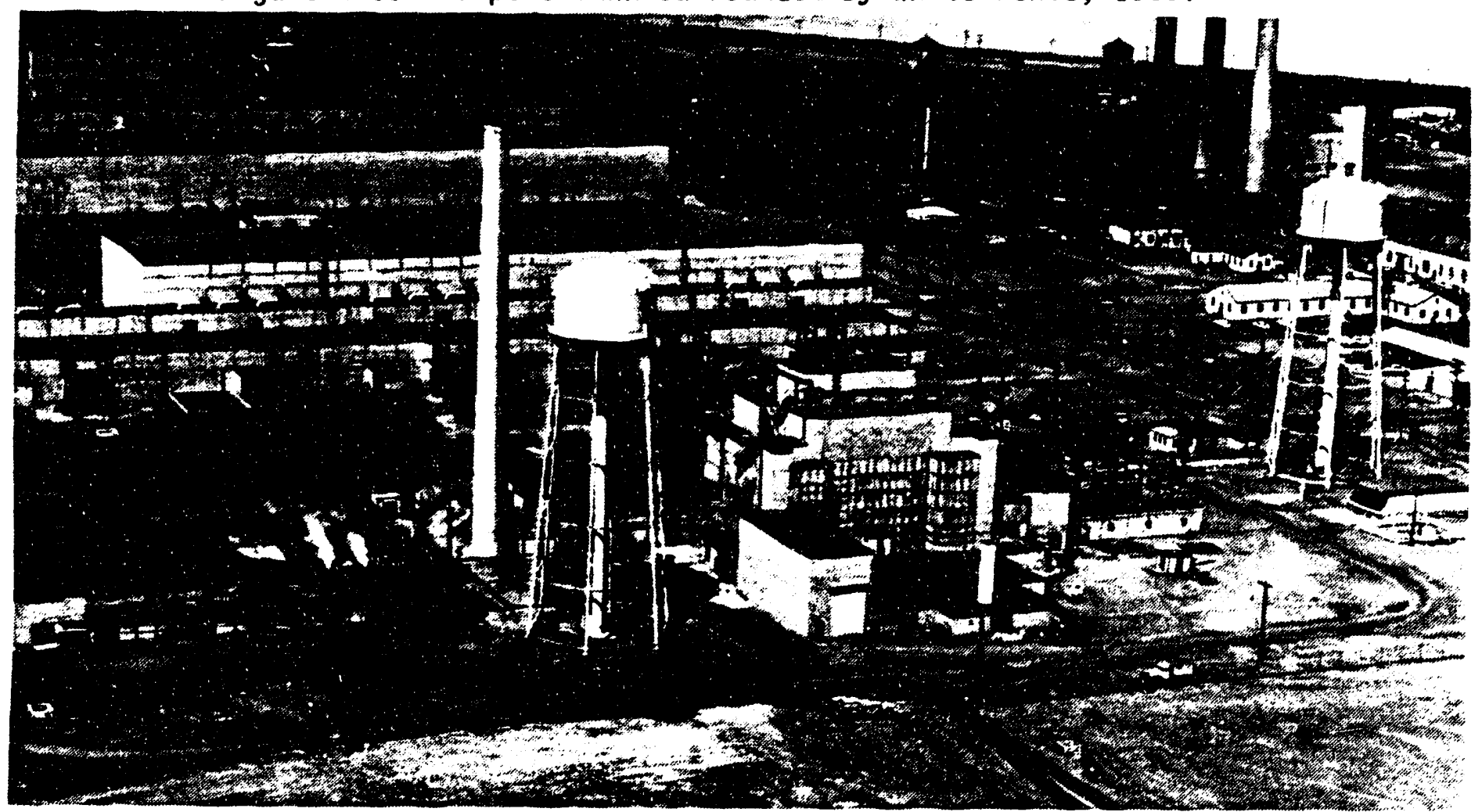

1964 post deactivation surveys indicated maximum smearable contamination on the internal surfaces of the DR gas tunnel to be $5,000 \mathrm{c} / \mathrm{m}$. The maximum dose rate observed was $30 \mathrm{mrad} / \mathrm{hr}$ including $5 \mathrm{mR} / \mathrm{hr}$ at $4 \mathrm{in}$. from the drain trough. No decontamination other than general housekeeping and flushing down with water was attempted (Winship 1965).

The building and adjoining tunnels were decommissioned in situ in 1985 and 1986 using allowable residual contamination level (ARCL) methodology. Decommissioning took place in two phases: phase one removed asbestos and contaminated equipment, phase two provided an unconditionally released work surface of the above grade structure and demolition of the facility. 
The facility's super-structure was demolished, and the "clean" rubble was taken to the 190-DR (126-DR-1) clearwell pit for disposal in 1986 (Jacques 1987). Tunnel pipes and valves were left in place. 0il from the seal pit was tested for PCB contamination (PCB content was a maximum of $4 \mathrm{ppm}$ ), solidified in Petroset (registered tradename of Fluid Tech, Inc, Las Vegas, Nevada), and packaged for burial in the 200 west area burial grounds. The tunnels were buried in situ by excavating down to the tunnel roofs and collapsing the roof sections into the tunnel. This process excluded the 1608-D 1 ift station and ended approximately $30 \mathrm{ft}$ from the railroad tracks that cross the tunnel about $175 \mathrm{ft}$ south of the 115-D/DR Facility.

The at- and below-grade structures (floor slab, walls, footing pedestals, tunnel roof and walls, pipes, and other structures) were exposed to at least $1 \mathrm{~m}$ below grade by excavation and then demolished using heavy equipment. The resulting rubble was placed in the basement and tunnels for in situ disposal. The resident radionuclides are tritium, C-14, Co-60, Sr-90, Cs-137, Eu-152, and $\mathrm{Pu}-239$.

The remaining $\mathrm{CO}_{2}$ gas storage units (1ast of the 110-D Gas Storage Faciitity) including the concrete pads and sheet metal covers were demolished and disposed of in the area landfill (Griffin 1987).

Currently the site appears much like a gravel parking lot and is free of debris (Figure 4-36).

Figure 4-36. 115-D/DR Gas Recirculation Facility.

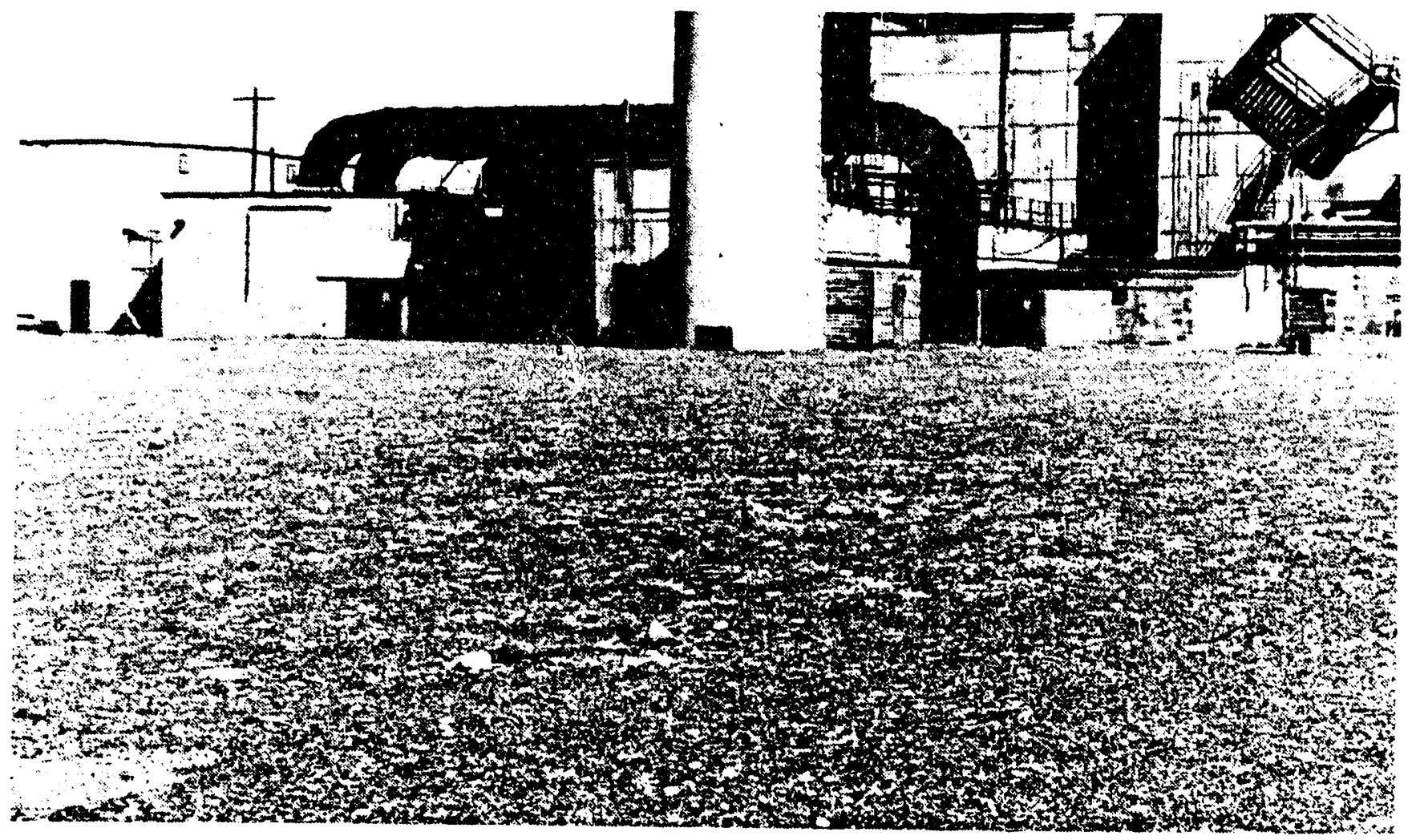


This waste site has not been assigned an HRS Migration score.

\subsection{2-D-2 (117-D FILTER BUILDING SITE)}

The 132-D-2 is an inactive solid waste site that operated from 1961 to 1967. The site is located at Hanford coordinates N92005 W52856 (northeast corner), which is about $100 \mathrm{ft}$ south of the 105-D Reactor Building. It was demolished in situ during 1986.

The facility received exhaust fan discharges from the 105-D Building through an inlet duct and released the filtered air through a discharge duct to the 116-D (132-D-4) exhaust stack.

Built in 1960 , the building was a $35-\mathrm{ft}$-high reinforced concrete structure that was almost completely below grade (about $8 \mathrm{ft}$ was above grade). The maximum thickness of the walls and floors was $2 \mathrm{ft}$ and the majority were $1 \mathrm{ft}$ thick or less. The ducts were made of reinforced concrete with a maximum wall thickness of $12 \mathrm{in}$. The inlet duct was $115 \mathrm{ft}$ long, and the exhaust duct was $92 \mathrm{ft}$ long.

The total radionuclide inventory in the 117-D Building was estimated to be $3.9 \mathrm{E}-3 \mathrm{Ci}$. The radionuclide inventory includes the following isotopes: $\mathrm{H}-3$, $\mathrm{C}-14, \mathrm{Co}-60, \mathrm{Sr}-90, \mathrm{CS}-137, \mathrm{Eu}-152$, and Pu-239. Contamination levels in 1978 ranged from 200 to $10,000 \mathrm{c} / \mathrm{m}$, with an average of 1,000 to $2,000 \mathrm{c} / \mathrm{m}$ (Dorian and Richards 1978).

The site was decommissioned using ARCL methodology. The filters, frames, and turning vanes were removed and packaged for burial at the 200 west burial grounds. The above-ground metal ducts were removed and used as burial containers which were also buried in the 200 West burial grounds (Griffin 1986).

Demolition and site grading were performed in January and February, 1986. They were accomplished by excavation of the building from $1 \mathrm{~m}$ below grade to the top portion of the ducts and by caving in the duct roofs and upper portion of the walls. The site was then partly backfilled with contaminated rubble and brought to grade with clean backfill material.

The contaminated rubble was buried at least $1 \mathrm{~m}$ deep, except for rubble from the seal pits, which was buried under a minimum of $5 \mathrm{~m}$ of clean earth. Prior to backfilling, holes were punched in the basement floor for drainage of any potential groundwater collection by infiltration.

The site today resembles a gravel parking lot and has not been assigned an HRS Migration score (Figure 4-37).

\subsection{2-D-3 (1608-D WASTE WATER PUMPING STATION SITE)}

The 132-D-3 is an inactive liquid waste site that operated from 1944 to 1965. It is located at Hanford coordinates N92106 W52755, which is adjacent to the south side of 105-D within the 105-D/DR exclusion fence. The 132-D-3 was also known as the 1608-D effluent pumping station. It was demolished in situ during 1986 and 1987. 
Figure 4-37. 117-D Confinement Air Filter Facility.

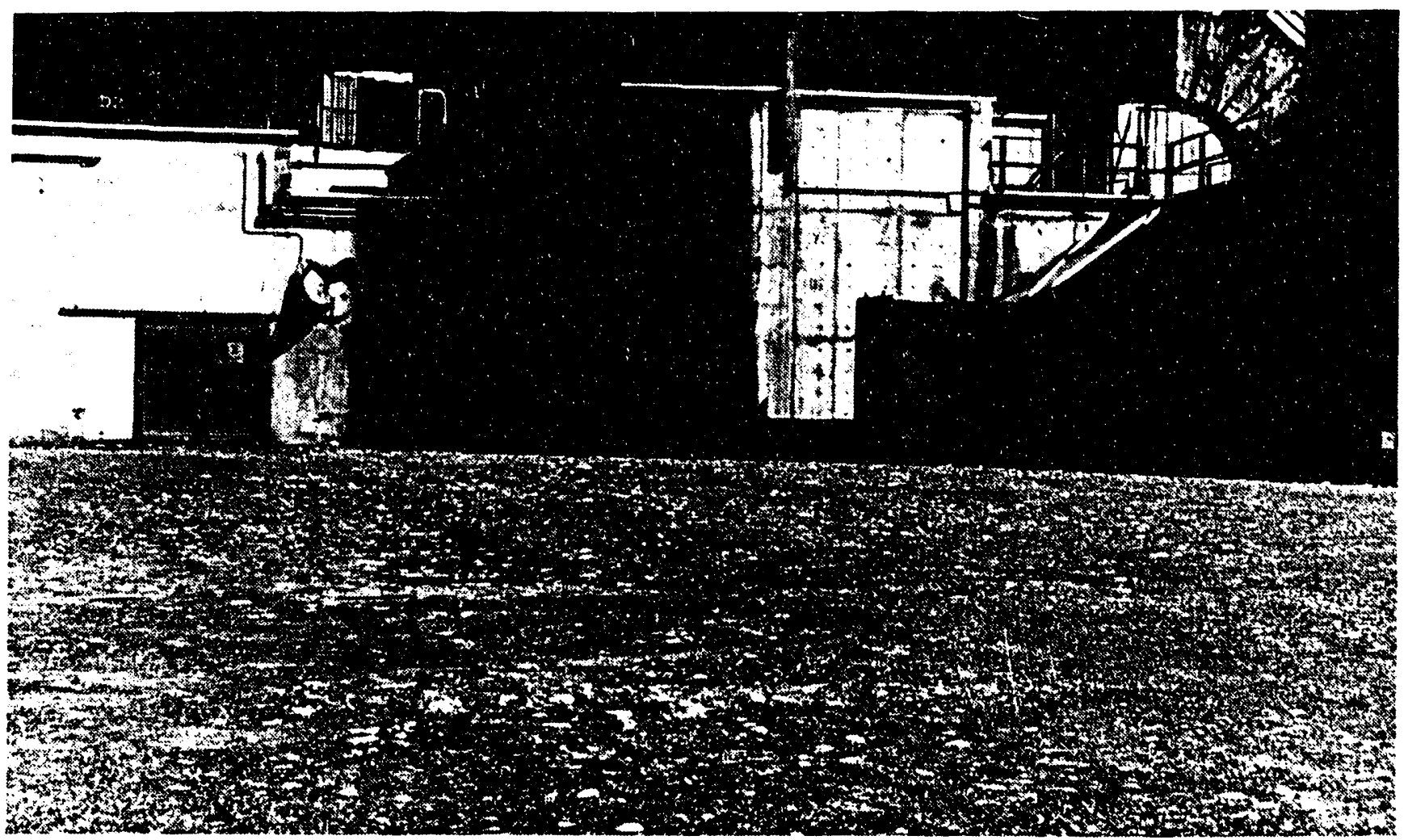

The facility received waste water from reactor drains; the primary source was the fuel storage basin overflows (DOE 1992b). These drains contained trace amoints of low-level radionuclides and decontamination chemicals. The radionuclides were primarily miscellaneous fission and activation products. Decontamination chemicals consisted of sodium fluoride, oxalic acid, and citric acid. The waste water was pumped from reactor collection pits into the reactor effluent lines near the reactor building and became part of the effluent that was discharged to the Columbia River (WHC 1991).

Prior to decommissioning, the structure extended $4 \mathrm{ft}$ above grade and 32 $\mathrm{ft}$ below grade. The walls and floor were constructed of reinforced concrete and the roof had a wood frame with a composition surface. The facility included an accumulation sump that supplied three separate sumps.

Decommissioning was performed in two phases: phase one, which was completed April 4, 1986 , consisted of water removal ( $240 \mathrm{gal}$ ), asbestos removal/disposal (40 $\mathrm{ft}^{3}$ ), and pump and piping removal; phase two, which was completed January 6, 1987, consisted of demolition (in situ) and site grading. The facility was covered with $1 \mathrm{~m}$ of clean soil (WHC 1991).

The site appears today as a gravel parking lot (Figure 4-38) and has not been assigned an HRS Migration score. 
Figure 4-38. 1608-D Facility.

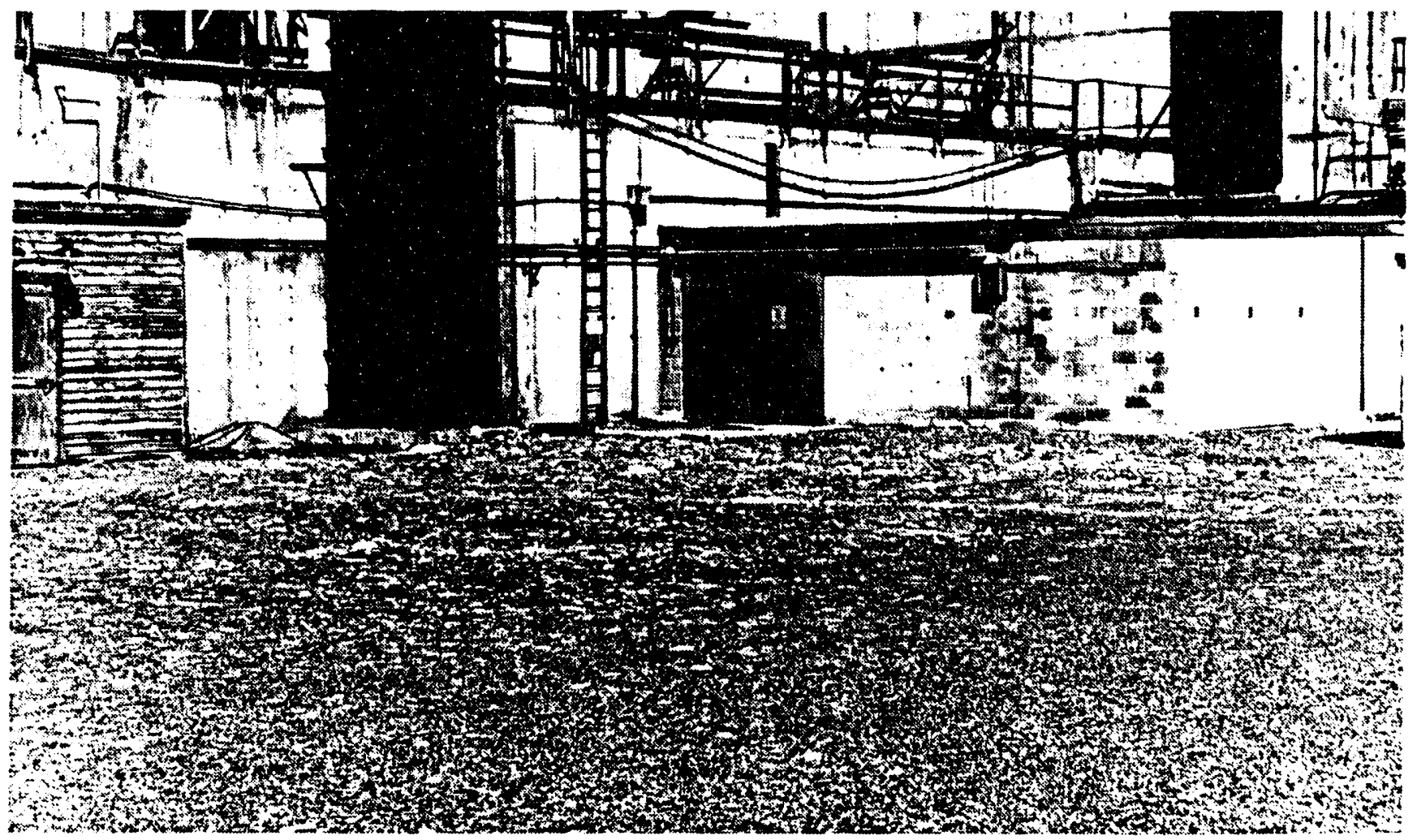

\subsection{2-D-4 (116-D REACTOR EXHAUST STACK)}

The $132-D-4$ is an inactive solid waste site that operated from 1944 to 1967. It is located at Hanford coordinates N92200 W52790, which is just south of the 105-D Reactor Building. The stack was used to discharge air that originated from work areas in the reactor building (PNL 1991). The interior contains an unknown quantity of low-level radioactive materials.

Originally, exhaust air flowed directly from the 105-D Building to the exhaust stack. Following completion of the reactor confinement project in 1950, the exhaust air was diverted to the 117-D Filter Building, via underground ducts, prior to release through the stack.

Dorian and Richards (1978) reported dose rates at the base of the stack to be less than $1 \mathrm{mR} / \mathrm{hr}$ with a general background level within the stack of approximately $1,000 \mathrm{c} / \mathrm{m}$. The survey was conducted with a GM probe. Low level smearable alpha was present up to $130 \mathrm{dpm} / 100 \mathrm{~cm}^{2}$. Smearable beta contamination ranged from 100 to $5,000 \mathrm{dpm} / 100 \mathrm{~cm}^{2}$.

Decommissioned in 1987, the 132-D-4 exhaust stack is a monolithic, reinforced concrete structure with a maximum wall thickness of $1.5 \mathrm{ft}$ at the base. It rests on a double octagon-shaped base that extends $17.5 \mathrm{ft}$ below grade. The stack is $16.58 \mathrm{ft}$ in diameter at the base and extends $200 \mathrm{ft}$ above grade. An opening at the base provides access to its interior portion. This opening is fitted with a steel door. The stack remains standing, and the inlet plenum is sealed (WHC 1991). 
It appears today much the same as when it was originally constructed. The steel ladder rungs have been removed to about ten feet above grade to discourage unauthorized climbing of the stack. This waste site has not been assigned an HRS Migration score.

Figure 4-39. 628-3 Suspect Site.

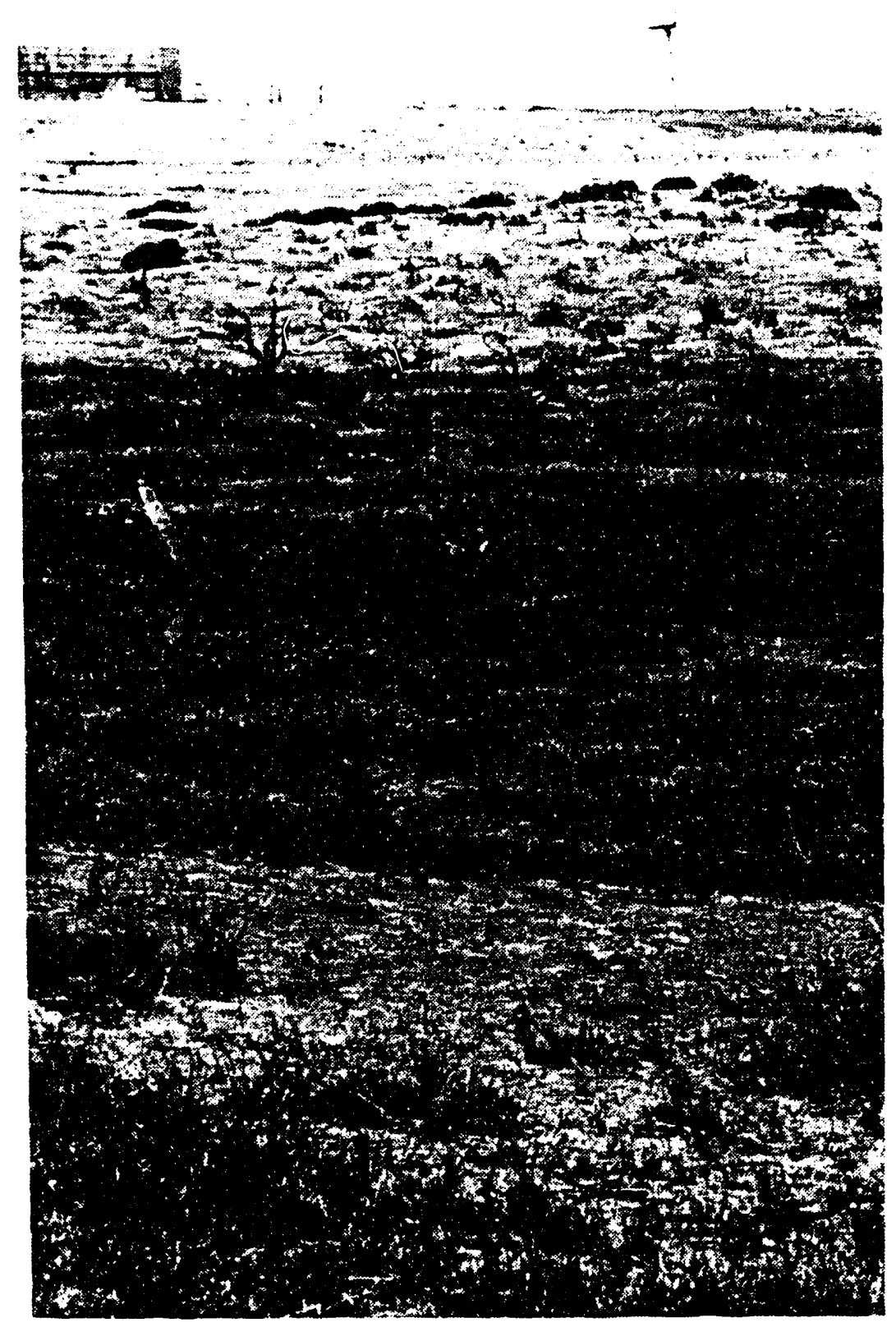

\subsection{8-3 (BURN PIT)}

The 628-3 is an inactive solid waste site that is located at Hanford coordinates $\mathrm{N} 93280 \mathrm{~W} 49500$, which is about $1,000 \mathrm{ft}$ east of the 128-D-2, burn pit and about $300 \mathrm{ft}$ east of the D-Area perimeter road. The site is roughly oval ( 250 by $40 \mathrm{ft}$ ). The center is distinguished by a 4-ft depression that shows signs of severe plant stress and soil discoloration. The depression, as well as the area around it, is littered with debris consisting mostly of burnt wood, nails, metal pipes, rebar, and glass. It appears that at one time cat tractors bulldozed some of the surrounding soil. In some spots, the site also contained what looked like asbestos, both friable and non-friable (WHC 1991).

The pit is located outside and to the east of the 100-DR-1 Operable Unit boundary, causing its 628-3 designation.

This waste site could not be definitely located during site surveys conducted for this report. The site depicted in Figure 4-39 is the suspected site location. Several small pre-Hanford dump sites were located in the area of this burn pit (Figures 4-39 and 4-40). No asbestos, friable or non-friable, could be found. 
Figure 4-40. East of the 100-D Area Near the 628-3 Farm Dump.

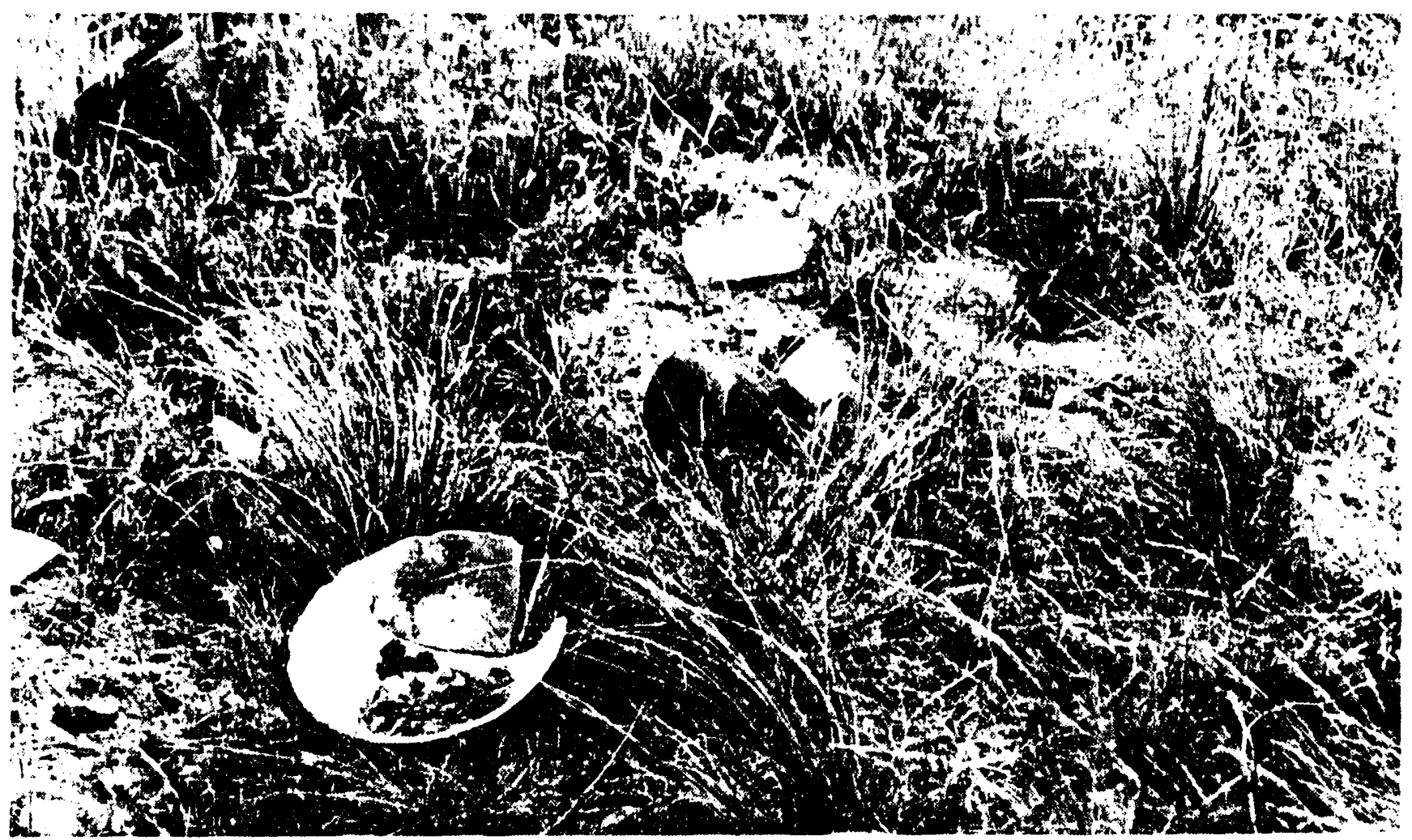

This waste site has not been assigned an HRS Migration score.

\subsection{7-D SEPTIC TANKS AND ASSOCIATED DRAIN FIELDS}

Four septic tanks are located in the 100-DR-1 Operable Unit. Two of these systems are active and are constructed of reinforced concrete with associated drain fields included. None are known to have received hazardous or radioactive wastes, although all supported facilities where hazardous and/or radioactive materials were routinely handled and used. 
Three of these septic systems have been assigned designation numbers while the fourth was identified as a suspect septic system and is identified in Table 4-7 as "Suspect."

Table 4-7. Septic Tank Systems.

\begin{tabular}{|c|c|c|}
\hline $\begin{array}{l}\text { SEPTIC TANK } \\
\text { DESIGNATION }\end{array}$ & $\begin{array}{l}\text { HANFORD } \\
\text { LOCATION }\end{array}$ & COMMENTS \\
\hline $1607-D 2^{*}$ & $\begin{array}{l}\text { N94300 } \\
\text { W52695 }\end{array}$ & $\begin{array}{l}\text { Supported } 189-D, 185-D, 182-D, 183-D, 1700-D \text { Administration and } \\
\text { Service Buildings and } 105-0 \text {. There are several clay brick manholes } \\
\text { associated with this septic system located throughout the } 100-D \\
\text { Reactor facilities area (Figures } 4-41 \text { and } 4-42 \text { ) }\end{array}$ \\
\hline Drain Field & $\begin{array}{l}N 95050 \\
\text { W52624 } \\
\end{array}$ & \\
\hline 1607-D4 & $\begin{array}{l}\text { N91850 } \\
\text { W52650 } \\
\end{array}$ & $\begin{array}{l}\text { Supported } 115-D / D R \text { (Figure } 4-35 \text { ). The septic tank can be seen to } \\
\text { the left surrounded by a white wood fence }\end{array}$ \\
\hline 1607-D5 & $\begin{array}{l}\text { N92900 } \\
\text { W55790 } \\
\end{array}$ & Supported 181-D (figure 4-43) \\
\hline SUSPECT & $\begin{array}{l}N 93050 \\
\text { W52850 }\end{array}$ & $\begin{array}{l}\text { Existence is questionable; according to drawings it is a drop } \\
\text { manhole structure to the } 1607-02 \text { system. No other information is } \\
\text { available (Figure } 4-44 \text { ) }\end{array}$ \\
\hline
\end{tabular}

Figure 4-41. 1607-D2, Septic Tank, 1993.

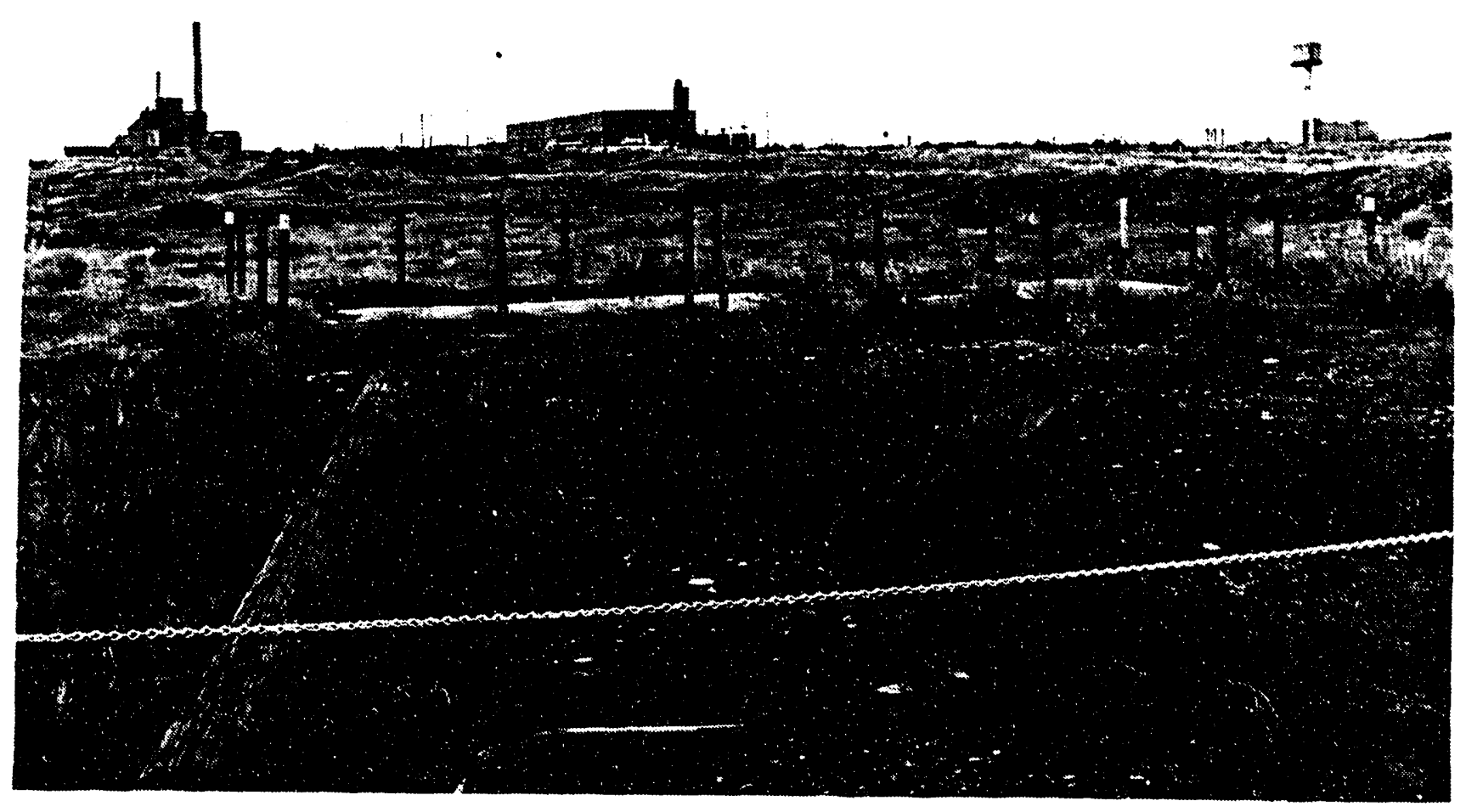


Figure 4-42. 1607-D2 Septic Drain Field, 1993.

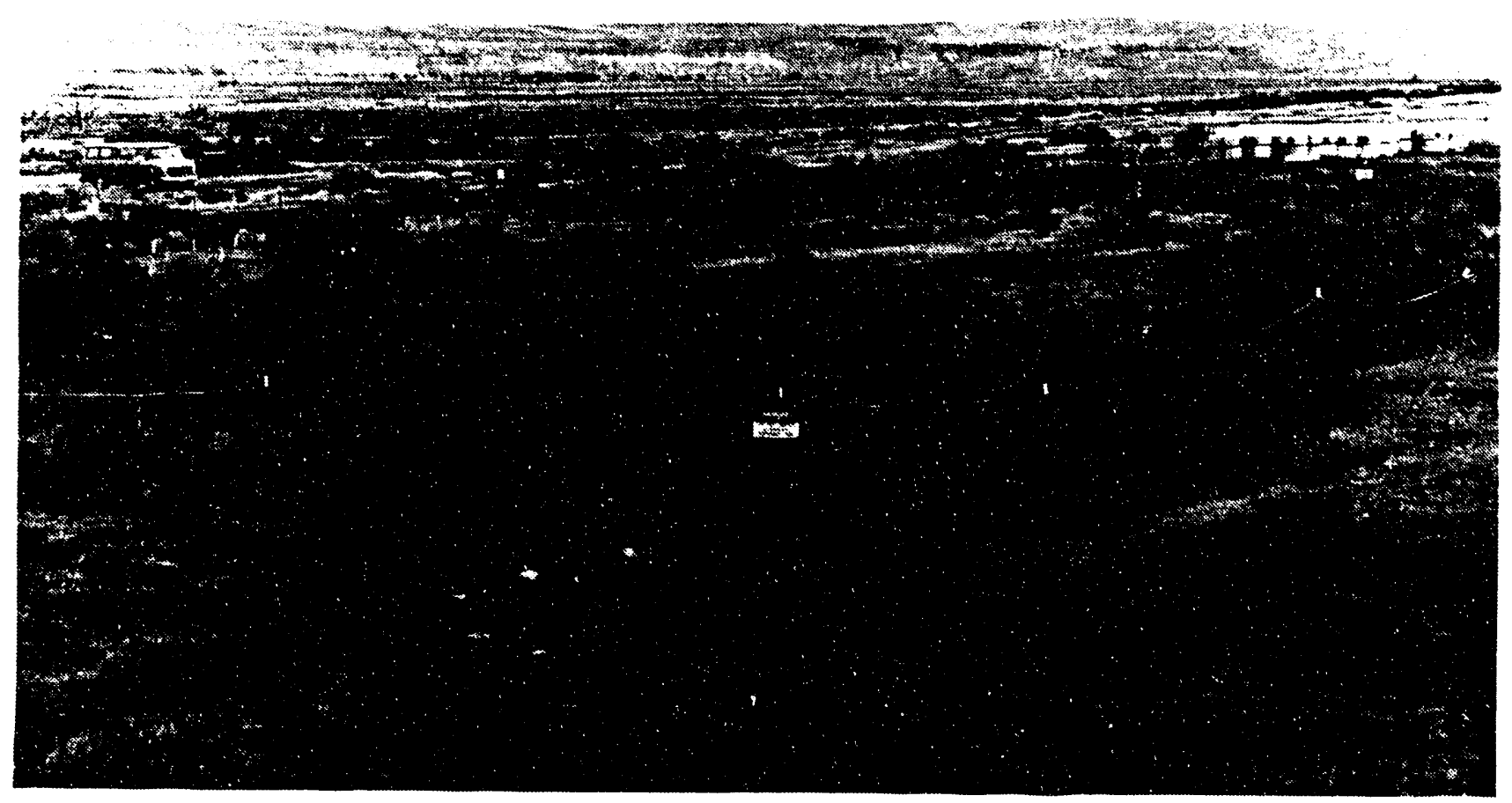

Figure 4-43. Septic System at 181-D.

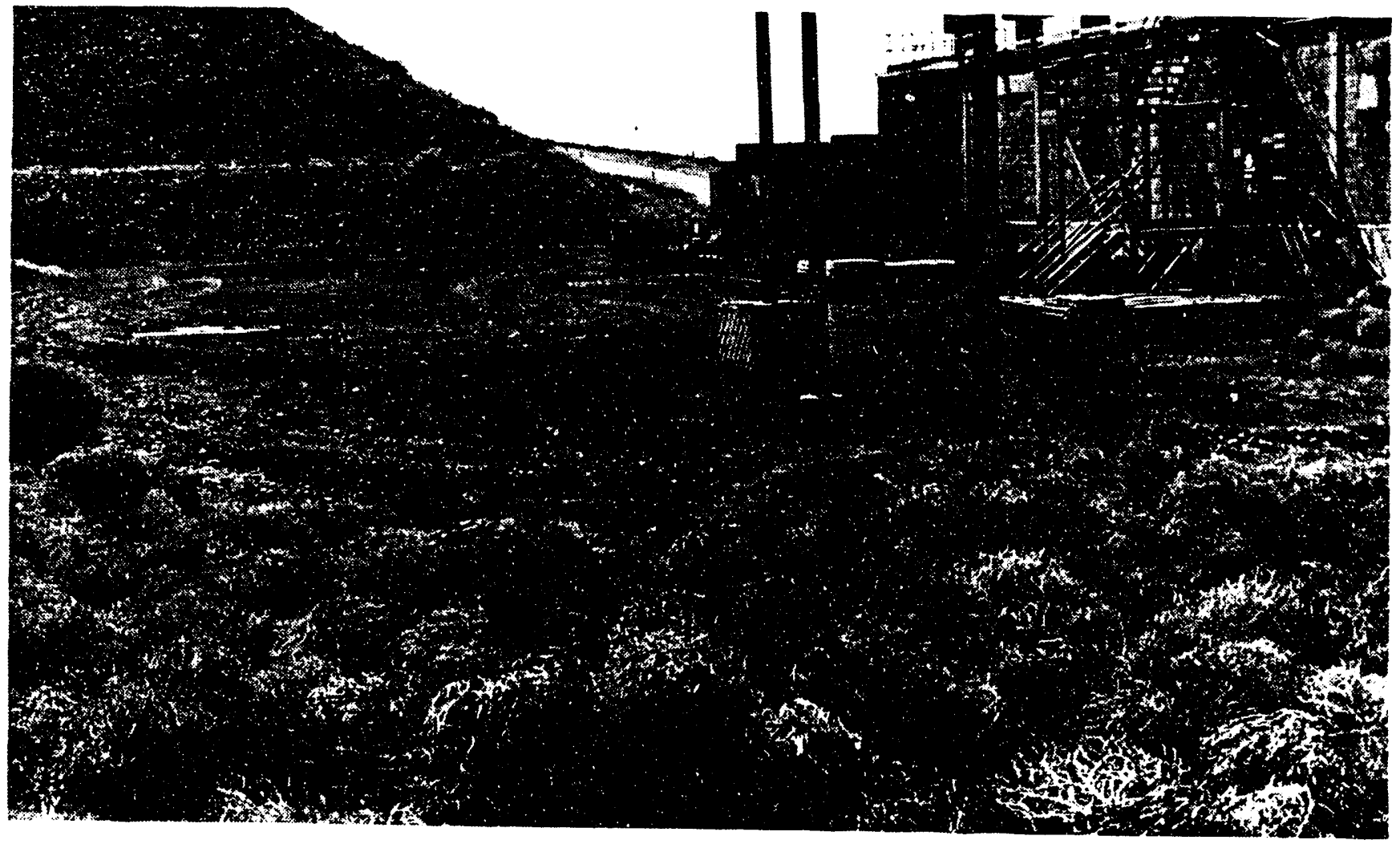


Figure 4-44. Suspe:i Septic System Manhole.

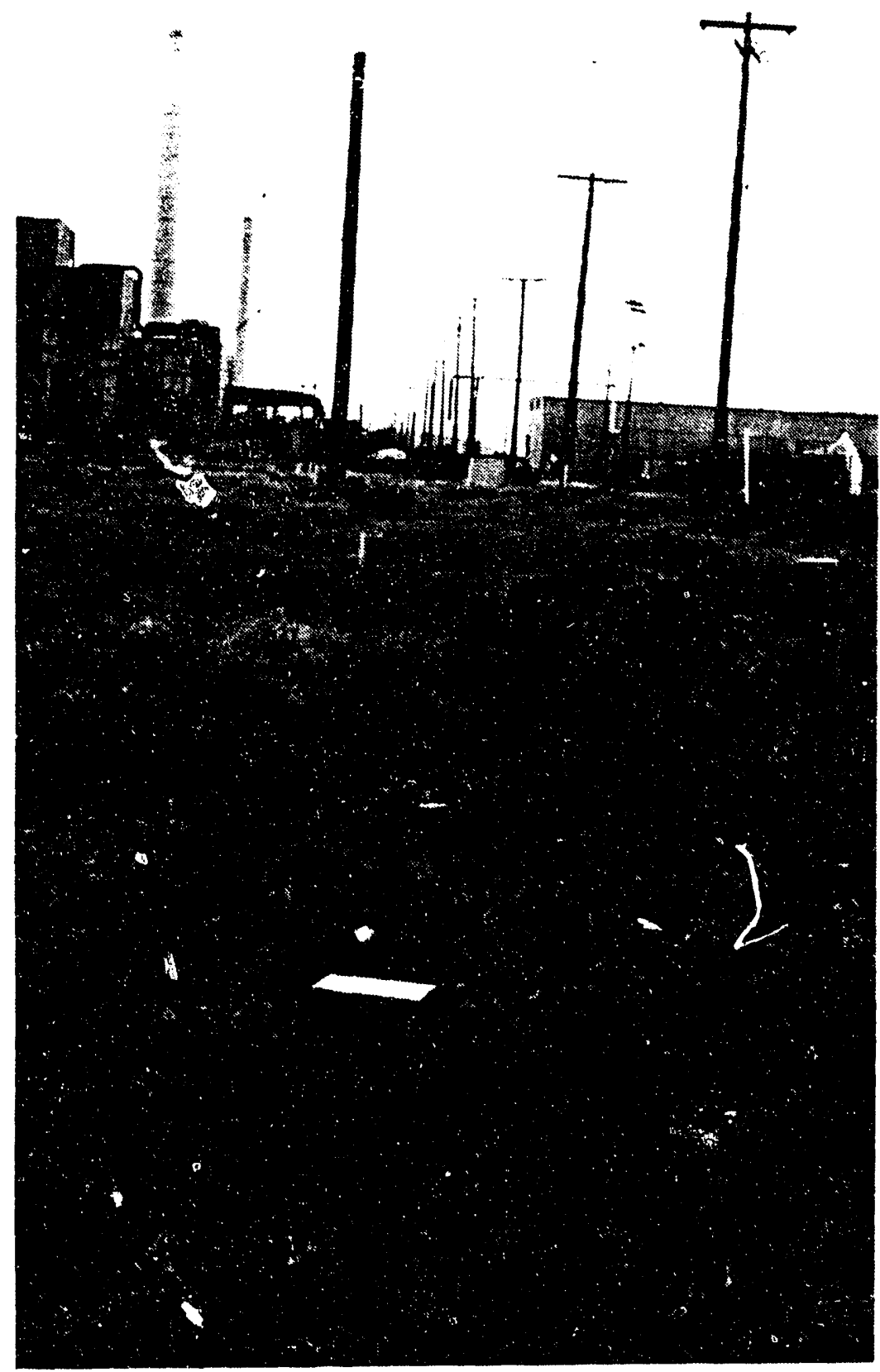

* During a field visit on March 7, 1989, a small quantity of flow was observed along the pipeline at the 1607-D2 tank (DOE 1992b). The drain filld for this septic system was moved to a large area north of the 107-DR retention basin in 1950. This drain field is north of the perimeter road and between the road and the river bank. It is a large area that is surrounded by a light chain and steel fence post barricade and is posted with "Danger No Unauthorized Personnel Allowed" signs.

Along the north boundary and about $8 \mathrm{ft}$ in from the light chain barricade is a row of vertical 4-in. concrete vent pipes that are about $6 \mathrm{ft}$ apart and extend about $2 \mathrm{ft}$ above grade. Approximately 36 of the pipes are standing and one has been knocked over. They all have loosely-fitting steel caps, and two bear blue labels (in very poor condition) that identify the area as a drain field.

There are several clay brick manholes associated with this septic system. Four of these are directly north of the 100-D Reactor, in line and approximately 50 yds apart. ish manhole

is about $10 \mathrm{ft}$ deep. The southernmost of these, located at N93050 W52850, is also idenitified as a suspect septic system. It appears to be a junction tox for the sistic system where the 1700 series building sewer lines tie in.

The tank is located just east of the 100-D effluent pipeline and west of the 107-DR retention basin in a posted surface contamination area. As of March 17, 1993, there was a small volume of flow in the bottom this system 


\subsection{UNDOCUMENTED LIQUID WASTE SITE, TRENCH NEAR 107-D}

An additional trench was excavated in 1955 to receive eff 1 isent from the 107-D and 107-DR systems following an undetermined number of fuel cladding failures (Dorian and Richards, 1978). Approximate coordinates for this trench are N94698 W53149 (WHC 1991).

\subsection{UNDOCUMENTED SOLID WASTE SITE NEAR 103-D}

At the completion of the "D" and "DR" tie-in of the effluent lines phase of the job in 1950, contaminated soil and pipe were buried at a site just north of the 105-D and east of the 103-D Buildings. The material was covered by at least $2 \mathrm{ft}$ of soil and a removable concrete top. A wooden fence posted with radiation zone signs marked the area (Heid 1956). This site can be clearly seen in Figure 4-35, a photograph taken in June 1953.

The wooden fence no longer exists. Today the site is surrounded by a steel post and light-duty chain fence and is posted with Underground Radioactive Material warning signs (Figure 4-45).

This waste site has not been assigned an HRS Migration score.

Figure 4-45. Juspect Solid Waste Burial Site, 1993.

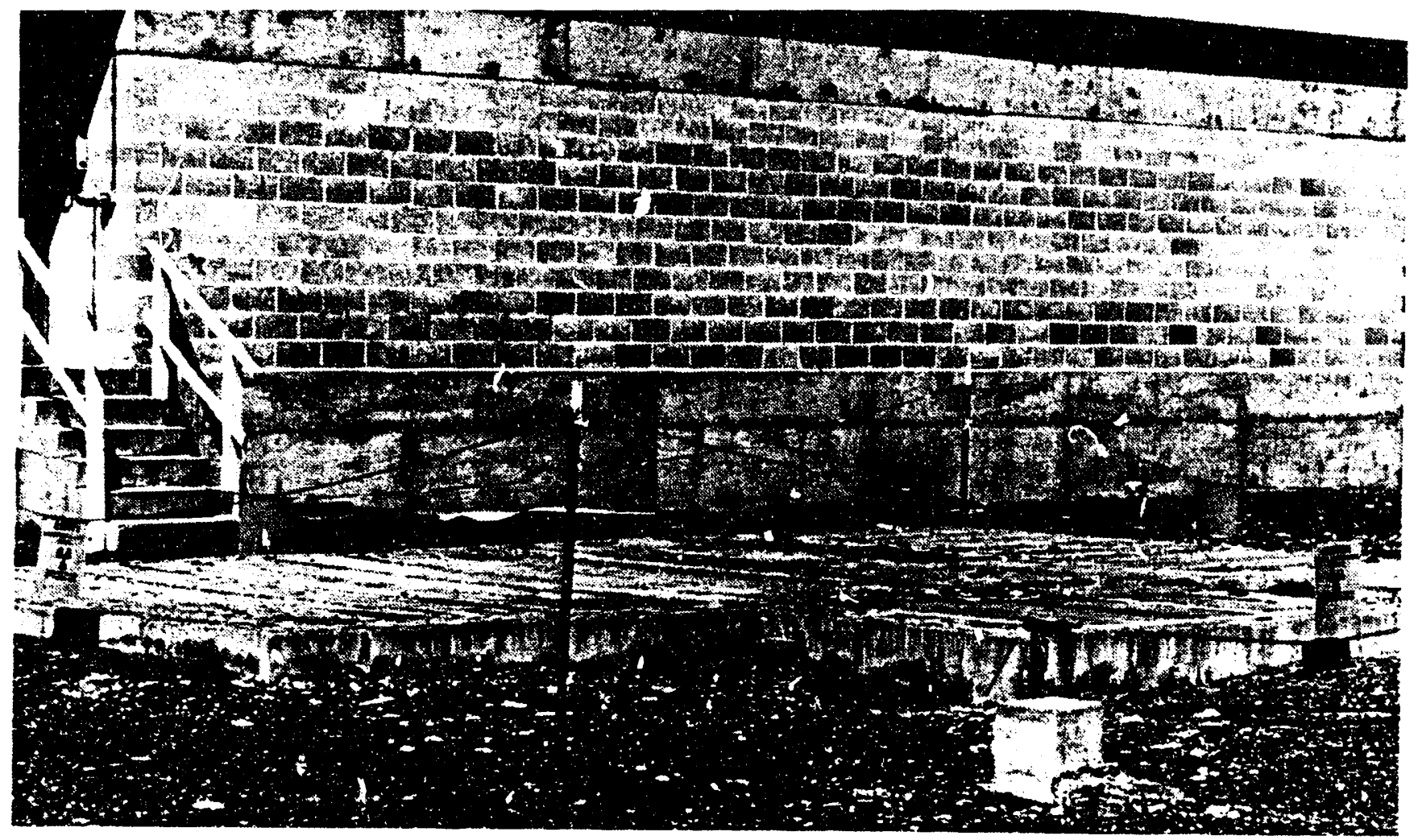




\subsection{UNDOCUMENTED SOLID WASTE SITE, BURIED VSR THIMBLE}

A vertical thimble removed from the 105-D Reactor in 1955 was buried in a trench and covered with several feet of dirt. The location is parallel with the north end of the 115-D/DR Building (Figure 4-46, site No. 16) (Heid 1956). It is believed that additional vertical safety rod thimbles were al so buried nearby and are marked above ground with three monuments (outside the exclusion fence but inside the buried effluent pipelines). This site can be seen on Hanford Drawing $\mathrm{H}-1-4046$, site No. 7 (Figure 4-47).

The thimbles were made of aluminum similar to the aluminum used in the process tubes and should therefore contain similar isotope composition. Sampling of process tubes was conducted in March 1967. The following results, decay corrected to March 1977, were obtained:

$$
\begin{array}{ll}
\text { Radionuclide } & \mathrm{pCi} / \mathrm{gAL} \\
\mathrm{Mn}-54 & 5.9 \times 10^{3} \\
\text { Co-60 } & 2.5 \times 10^{7}
\end{array}
$$

(Dorian and Richards 1978)

Additionally, the thimble's exterior surfaces would have been contaminated with activated graphite products and any remaining potassium borate solution
within the thimble tube.

The site currently appears as a vegetation-free, cobble-covered field with three square concrete monuments (Figure 4-48).

\subsection{UNDOCUMENTED MINOR CONSTRUCTION SOLID WASTE BURIAL SITES}

The existence of the following burial grounds, which are identified in Heid (1955), was verified during a tour of the 100-D Area with Ralph Wahien on
May 16th, 1993.

Minor Construction burial ground number 1 . Contaminated thimbles, rod guides, and miscellaneous waste removed from the 105-D Reactor during an fence. The $3 X$ outage in 1953 were buried just outside the exclusion area was marked with cement monuments covered with $6 \mathrm{ft}$ of dirt and the location

Minor Construction burial ground number 4. Two trenches, running in a north-south direction, were first used in the fall of 1954 for the disposal of low-level wastes from the reactors. The trenches are about 50 by $100 \mathrm{ft}$ (H?id

Minor Construction burial ground number 5. One trench, running in a north-south direction, was used in the fall of 1956 for the disposal of ccntaminated material and equipment removed from the reactor buildings. A separate hole lies just east of this trench and was to be used for disposal of similar wastes. The center of both waste sites are located about $125 \mathrm{ft}$ south of the railroad tracks leading to the 105-D fuel storage basin and about 570 $\mathrm{ft}$ and $660 \mathrm{ft}$ east of the exclusion area fence (Heid 1956). This waste site is identified as burial ground \#18 in DOE/RL-89-09, Rev. 0 (Figure 4-46). 
Figure 4-46. 100-D Area Wastesites.

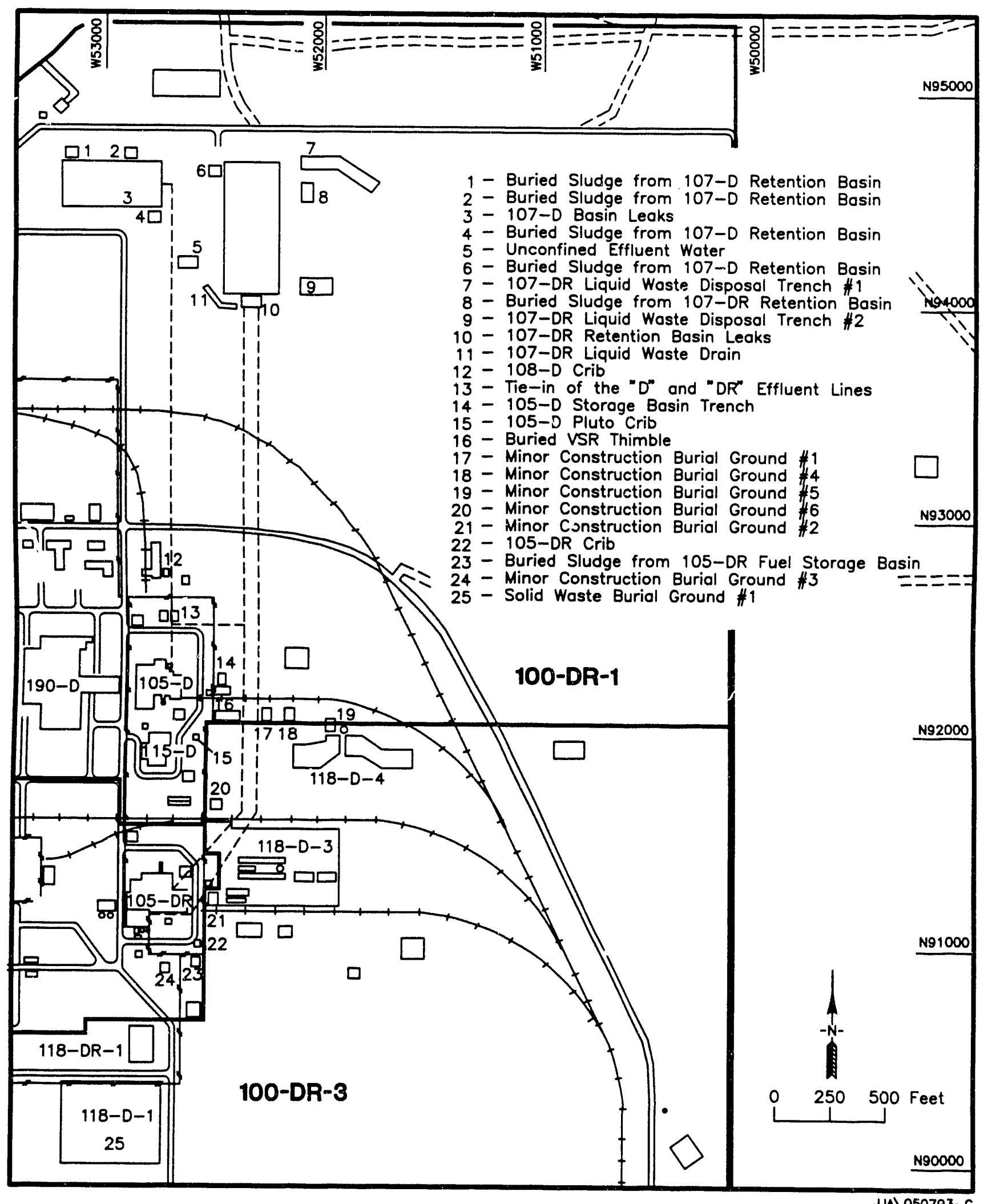


12. CONSTRUCTION C.G. S58ROD ZURIAL

13. CONSTRUCTION C.G. 553 .

WASTE EURIAL (SCLIOS)

14. SLUOGE EURIAL -OR

15. 105.DR GAS LOOP EURIAL

16. 105.0 PLUTO CRIB

17. OR. ZURIAL OF ROD THIMELES, GUIOES. ETC.

18. D. MISCELLANEOUS SOLIO WASTE

19. D. SOLID WASTE

20. DR - SLUDGE BURIAL FROM STORAGE BASIN

2!. RUPTUKE LIOUID NASTE

22. EFFLUENT LEAK

23. EFFLUENT LEAK

24. D- SLUOGE BURIAL

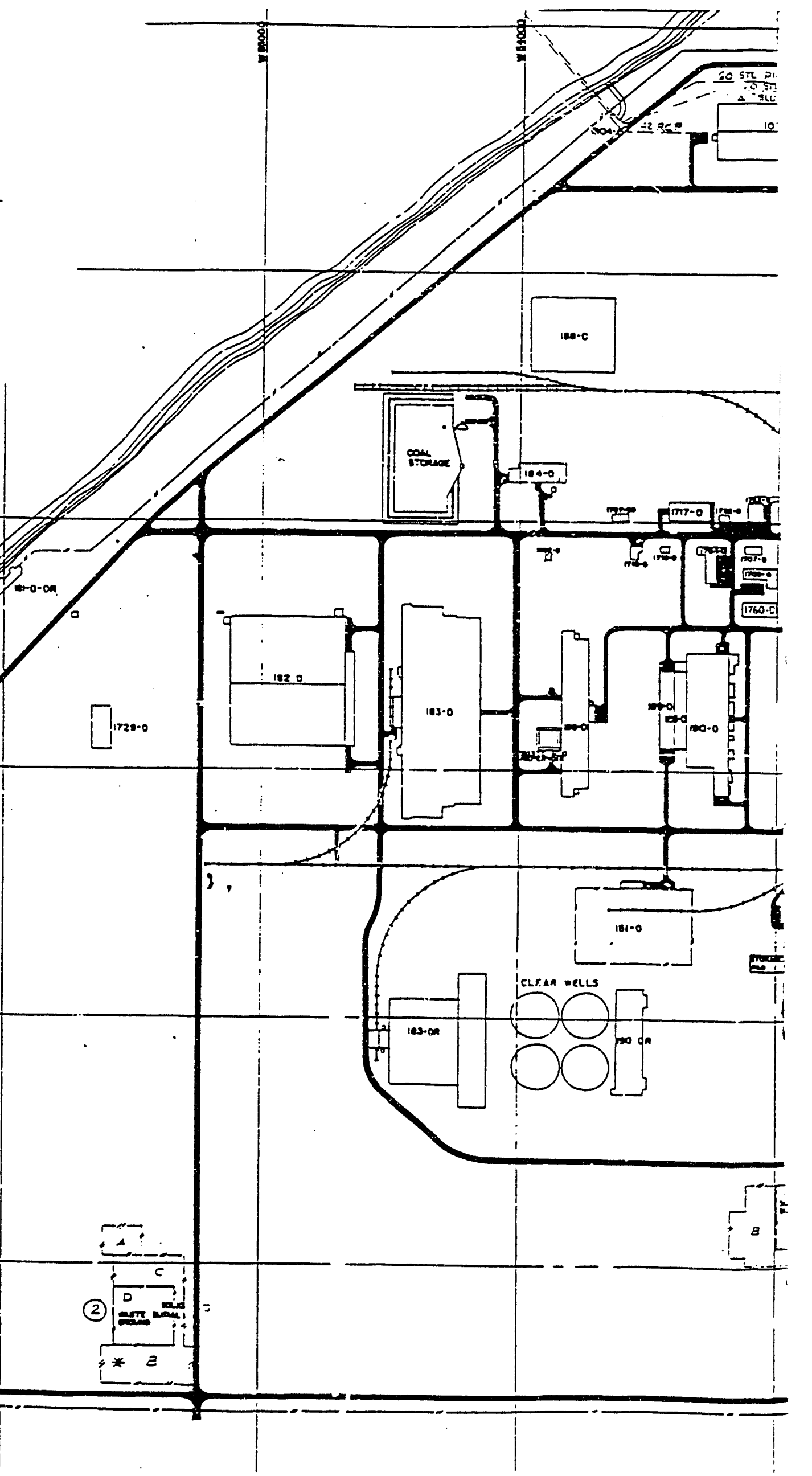




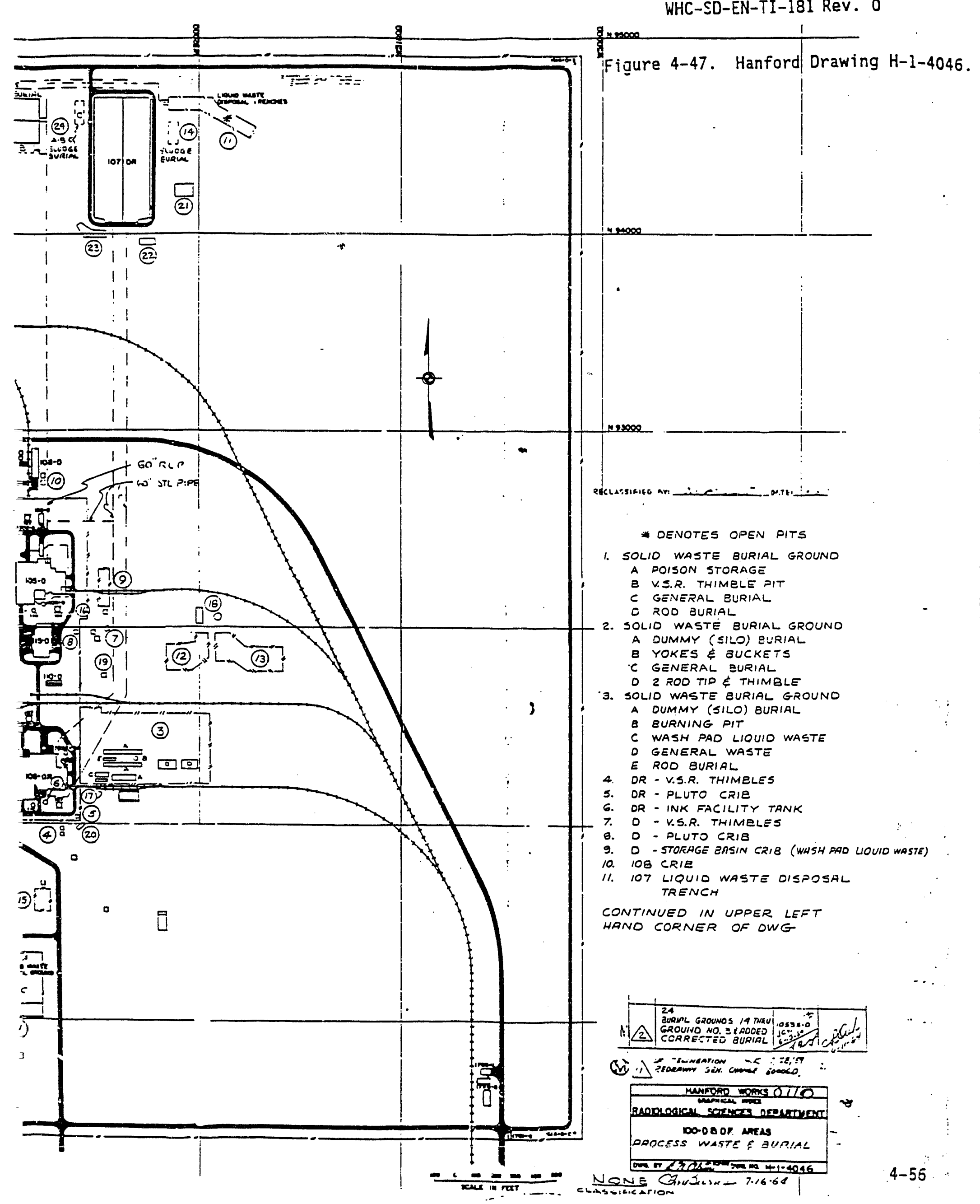


Figure 4-48. VSR Burial Ground.

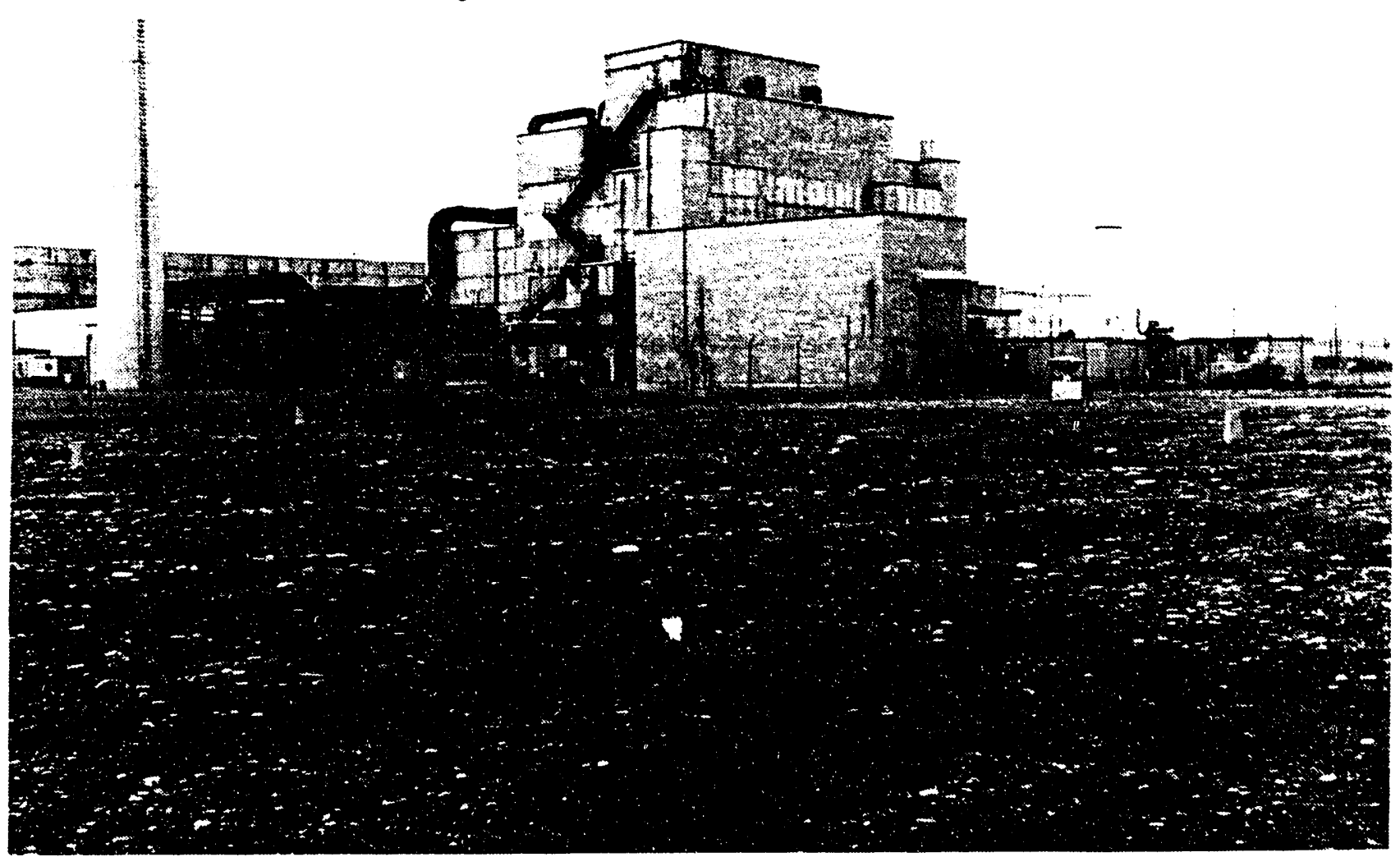

All of the Minor Construction sites mentioned above are shown in Heid (1956) as being just ncirth of the 118-D-4 burial ground.

These burial grounds appear today as vegetation-free, cobble-covered fields, with the exception of Minor Construction burial ground number 5 . This site lies partially outside the area currently bounded by permanent concrete markers and has natural vegetation growing on the surface (Figure 4-49). There are also concrete slabs located within this area that were reportedly foundations for temporary construction buildings during construction of $D$ Reactor facilities.

\subsection{UNDOCUMENTED SOLID WASTE BURIAL GROUND, SILICA GEL}

There was a small trench located about $100 \mathrm{ft}$ east and about $40 \mathrm{ft}$ north of the south end of the 115-D/DR (132-D-1) Facility which was used for the disposal of contaminated silica gel removed from the 115-D/DR drying iowers (Tatum 1967) (Figure 4-35: the area surrounded by the dark wood fence).

This site appears today much like a gravel parking lot. There is a recently placed concrete marker with a brass medallion embedded in the surface identifying this site as the 116-D-2A, which is a possible site of the 100-D pluto crib. 
Figure 4-49. Undocumented Solid Waste Site Outside Burial Ground Markers.

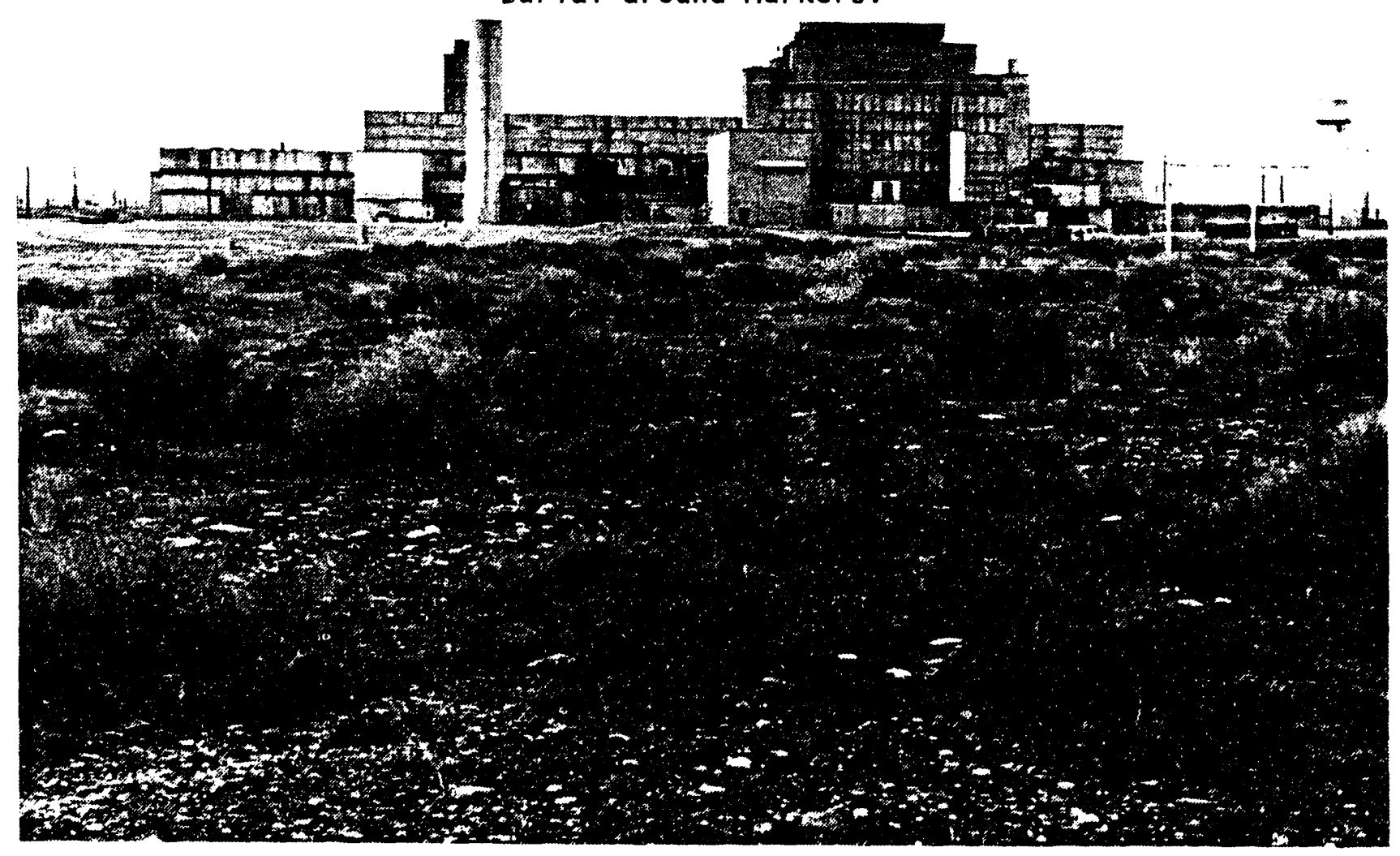

\subsection{UNDOCUMENTED SOLID WASTE SITE}

About 100 yds east of the 128-D-2 burn pit is a solid waste dump site that contains bundled 4-in. vitreous clay pipe, concrete cores, metal paint cans, and wood debris (Figures 4-50 and 4-51).

\subsection{UNDOCUMENTED LIQUID WASTE SIFE, 105-DR PROCESS SEWER OUTFALL SITE}

The 100-DR process sewer outfall (1907-DR outfall) was located at Hanford coordinates N92217.36 W56522.40, which is south of the 181-D Building on the river bank. This outfall was used to discharge waste water from the 183-DR and 190-DR water treatment facilities and from rain runoff drains including the 100-D Area cask pad and 100-DR facilities. There is slight potential for contamination due to the drain located on the 100-D Area cask pad, which was known to be contaminated on the surface. In 1987, this outfall was demolished (using a demolition ball), backfilled, and blended to match the surrounding river bank (Wahlen 1991) (Figures 4-52 and 4-53). 
Figure 4-50. Suspect Solid Waste Site East of the 100-D Area.

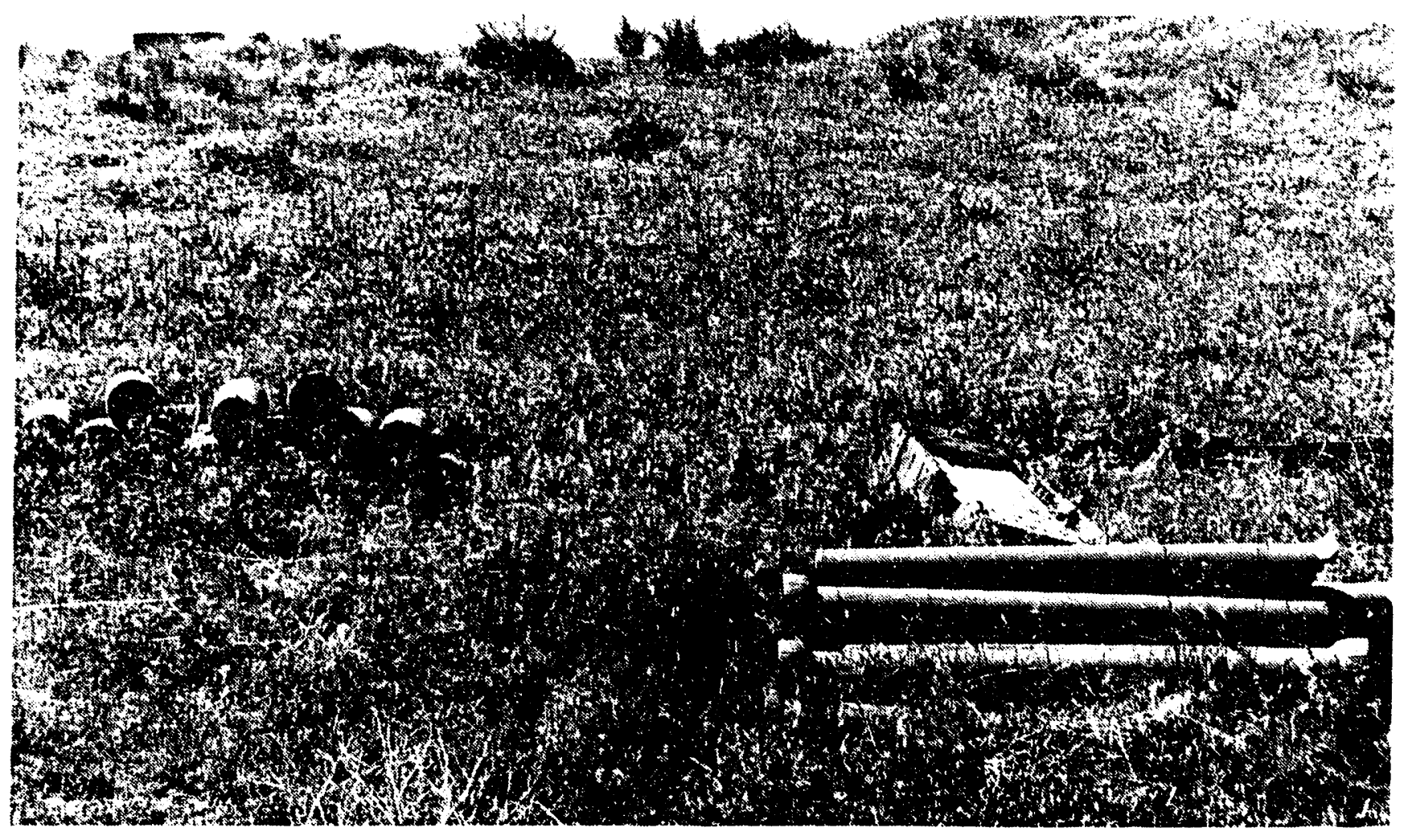

Figure 4-51. Suspect Solid Waste Site East of the 100-D Area.

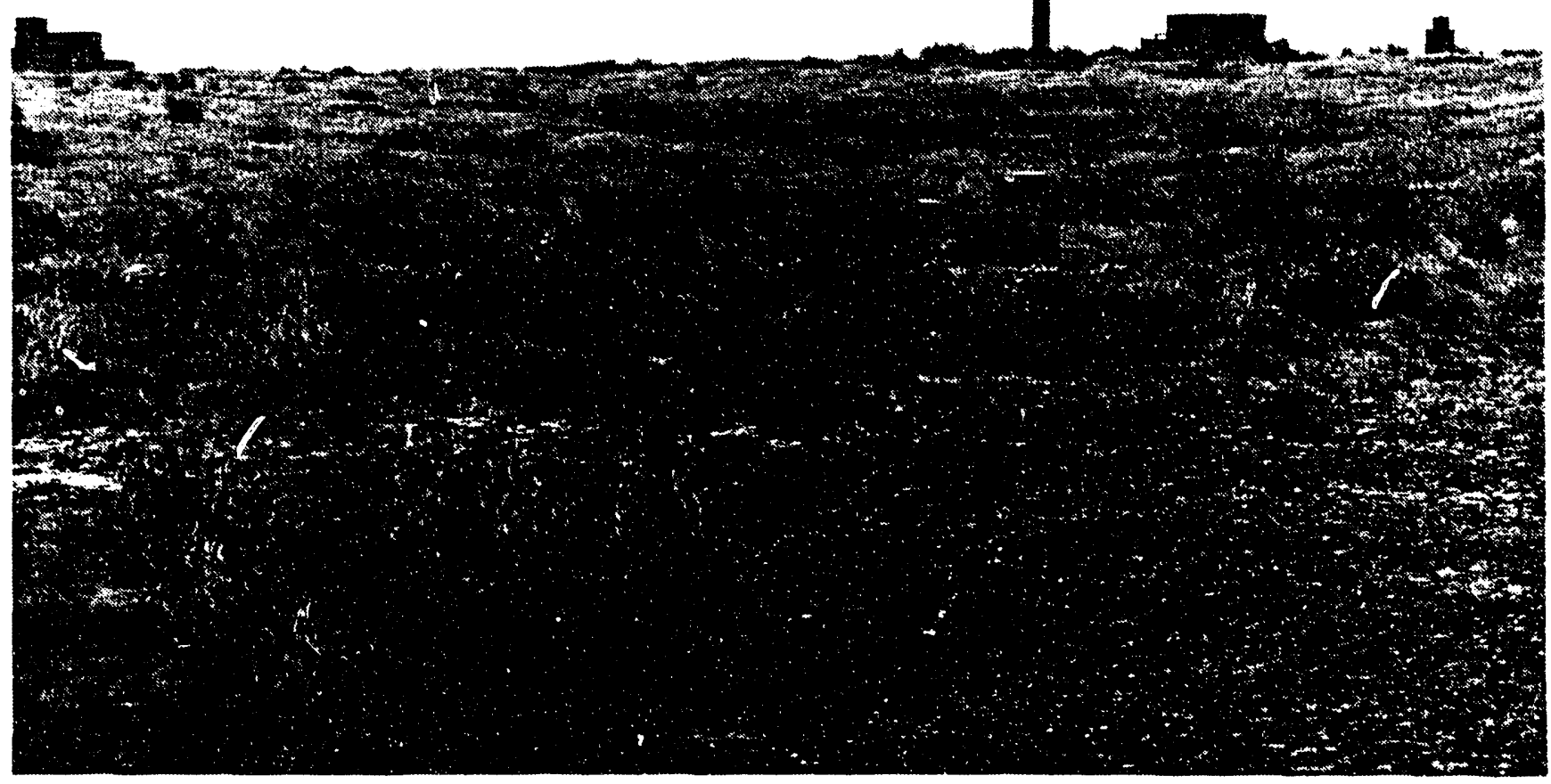


WHC-SD-EN-TI-181, Rev. 0

Figure 4-52. 1907-DR Outfall Before Demolition.

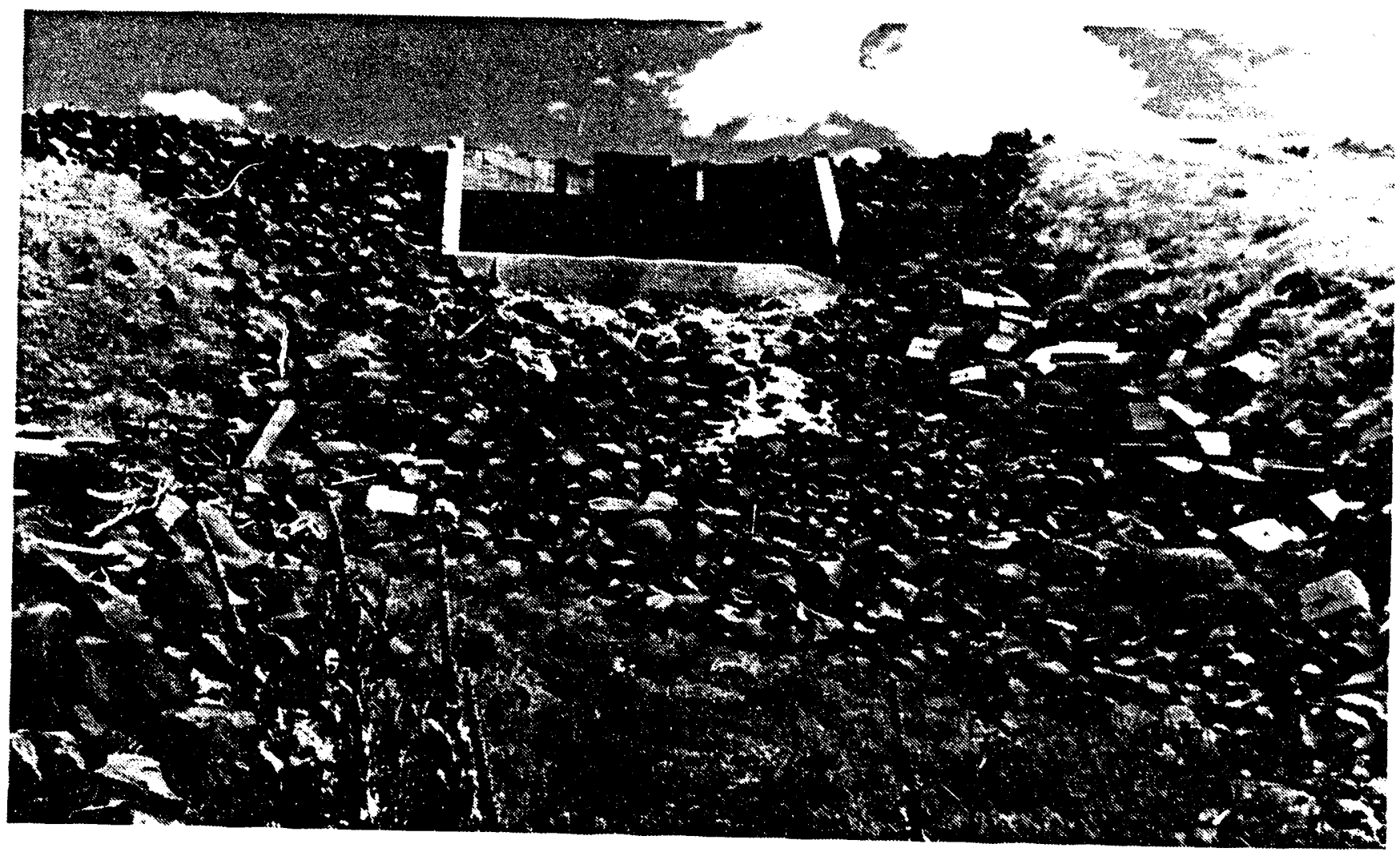

Figure 4-53. 1907-DR Outfal1, 1993.

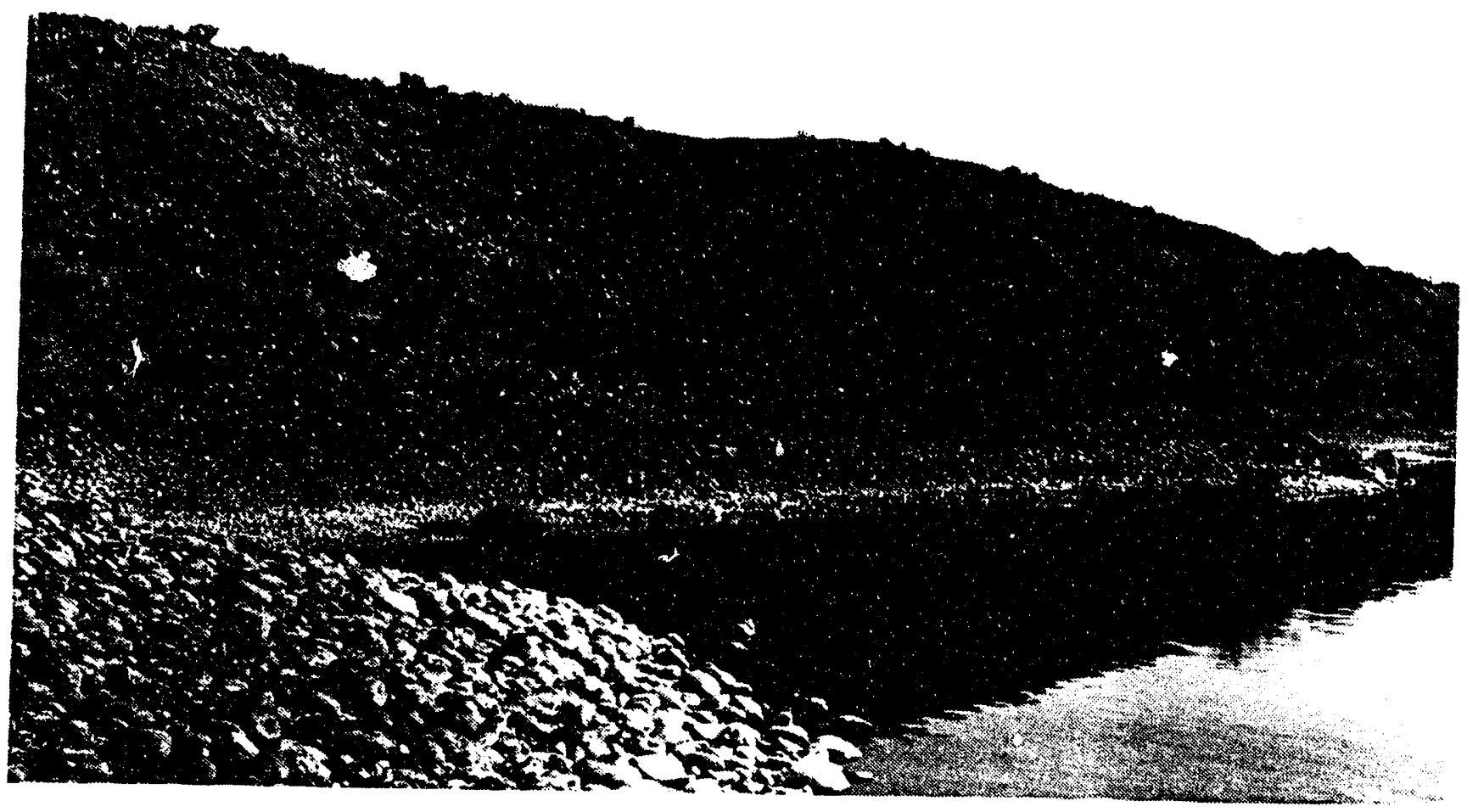




\subsection{UNDOCUMENTED LIQUID WASTE SITE, UNDERGROUND FUEL STORAGE TANKS}

In 1967 or 1968, an oil-fired boiler was installed at the 100-D Area to supply steam to the area facilities after the 184-D powerhouse was shut down. This boiler was located at Hanford coordinates $N 92750$ W53550. Two underground fuel storage tanks, of unknown size, were located just east of the boiler. The proposed location of the boiler and fuel storage tanks are shown on Hanford Drawing SK-1-71631. The existence of this boiler has been confirmed by WHC personnel who are familiar with the area, but it could not be confirmed that the fuel tanks were ever installed at or removed from the site.

Figure 4-54. Suspect Liquid Waste Site, Storm Drain Near 1904 Outfalls.

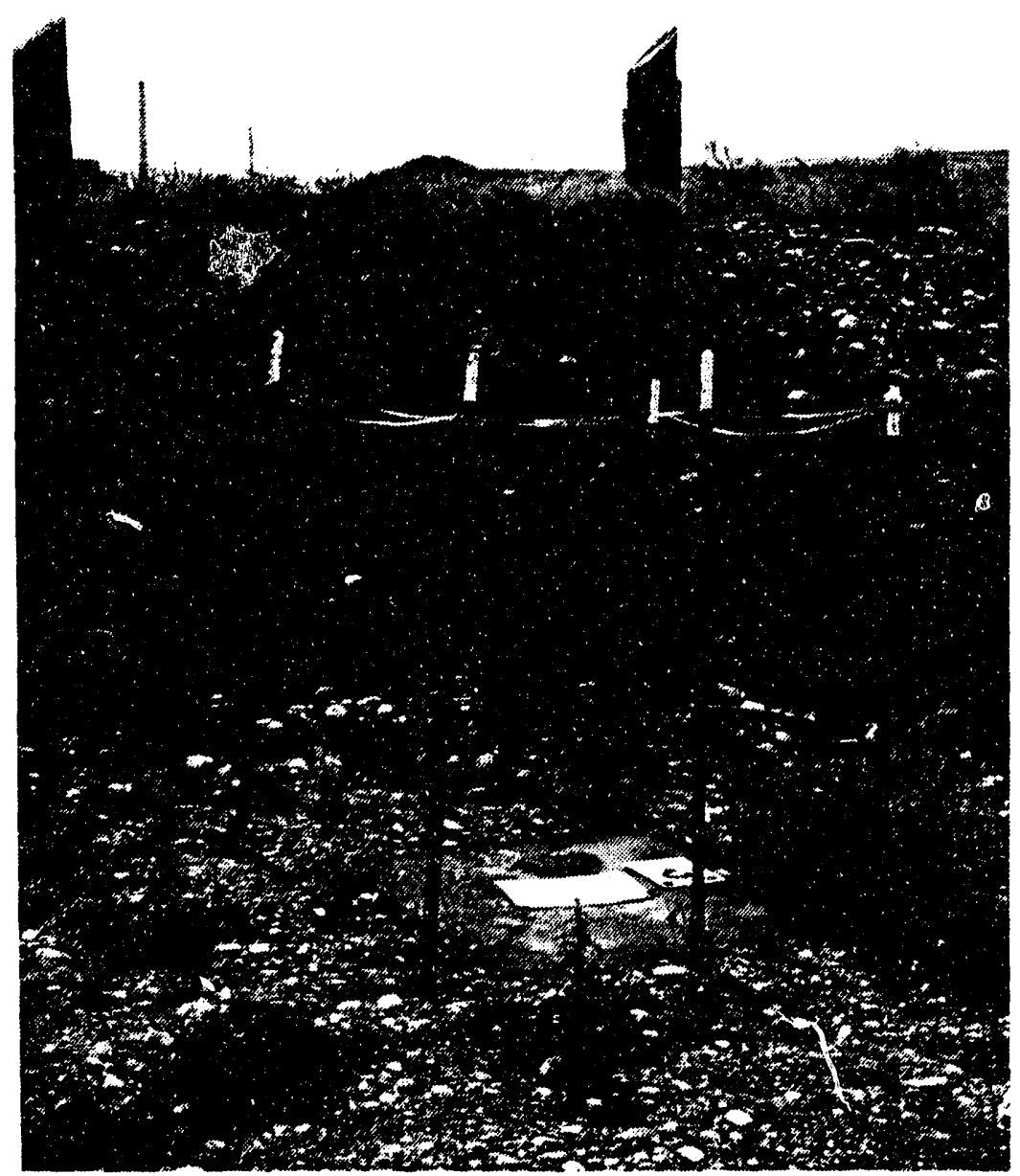

\subsection{UNDOCUMENTED LIQUID WASTE SITE, CONTAMINATED STORM DRAIN}

Located just north of the patrol road between the 1904-D and 1904-DR outfall structures is a small concrete storm drain box that is covered with a steel plate. It is posted with a Surface Contamination radiological warning sign. The site is surrounded by steel post and light-duty chain barrier. Drawings indicate that this storm drain was installed to provide drainage from the south side of the patrol road. It probably became contaminated by effluent water leakage from the nearby retention basins. It is unknown if the drain pipe from this box to the river remains in place. Reportedly, it has been removed (Figure 4-54).

\subsection{UNDOCUMENTED SOLID WASTE SITE, LEAD SHEETING}

Located $25 \mathrm{ft}$ south and $245 \mathrm{ft}$ west of the 100-DR annex of the 190-D Building is a small concrete pad that is covered by lead sheeting. The purpose of this structure could not be determined by documentation (Figure 4-55). 
Figure 4-55. Lead Sheet Cover on Concrete Pad South of the 186-D Building Site.

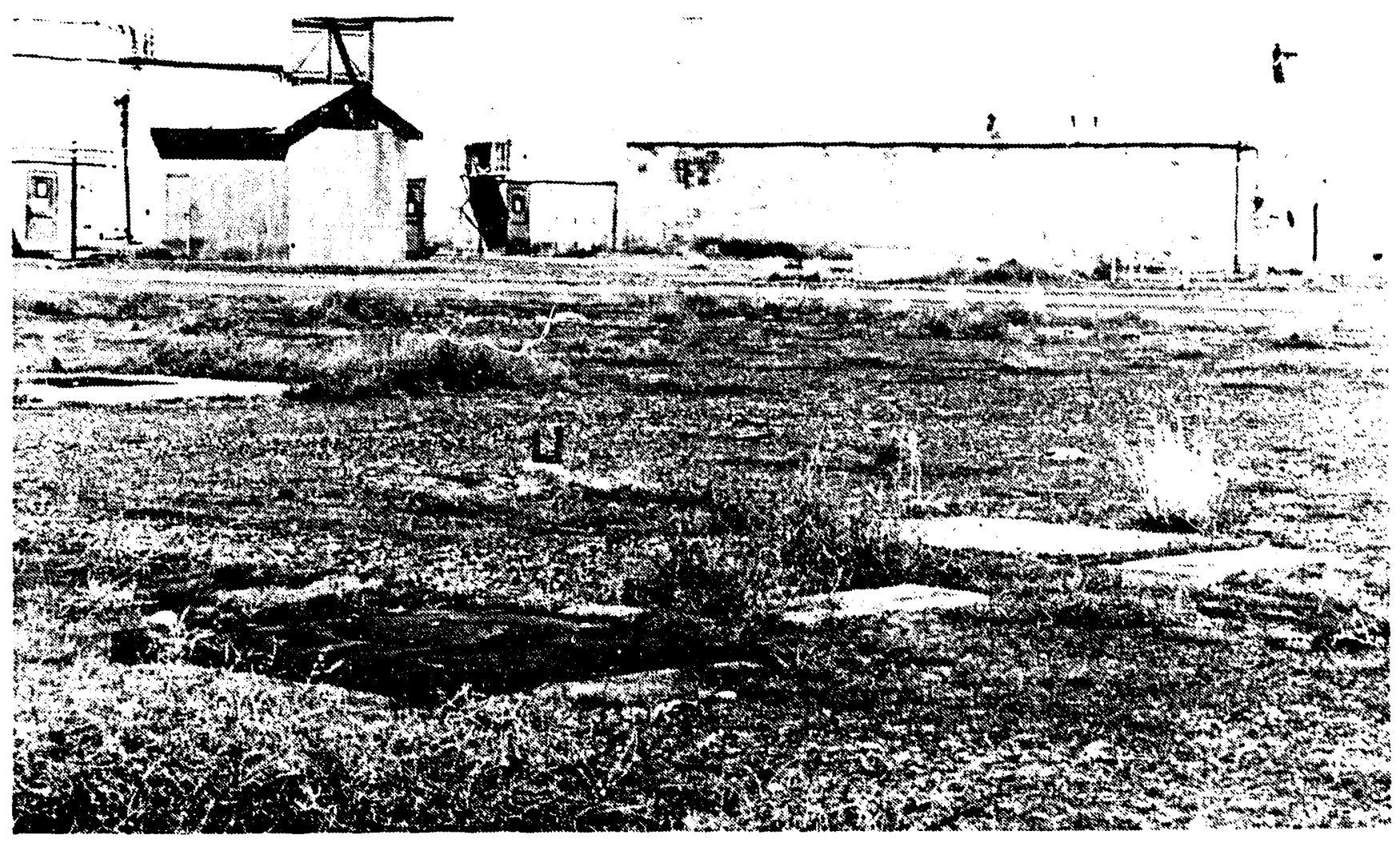

\subsection{UNDOCUMENTED LIQUID WASTE SITE, OIL SOAKED SOIL}

Located $60 \mathrm{ft}$ east of the 190-D Building Trampoline Test Facility and about $15 \mathrm{ft}$ south of the paved road leading to the test facility is a soil depression that is surrounded by oil-contaminated soil. The origin of the oil could not be determined and the total volume appeared to be small (Figure 456).

\subsection{UNDOCUMENTED LIQUID WASTE SITE, STORM DRAIN OUTFALL}

Reportedly there was a small concrete outfall structure upstream of the 1907-DR outfall structure that was demolished at about the same time as the outfall. The structure was similar in construction to the 1907-DR, only much smaller. It was used as a jischarge outfall for the storm drain system of the 190-DR tank pit, which consisted of drains, sump, and pump to 1 ift runoff to the ouifall. The outfall is located adjacent to the concrete block telephone building on the river bank, just south of the 100-Area fence. The trench from the outfall structure to the waterline is apparent and appears to have a telephone cable buried in its bottom. 
Figure 4-56. 0il-contaminated Soil East of 190-D.

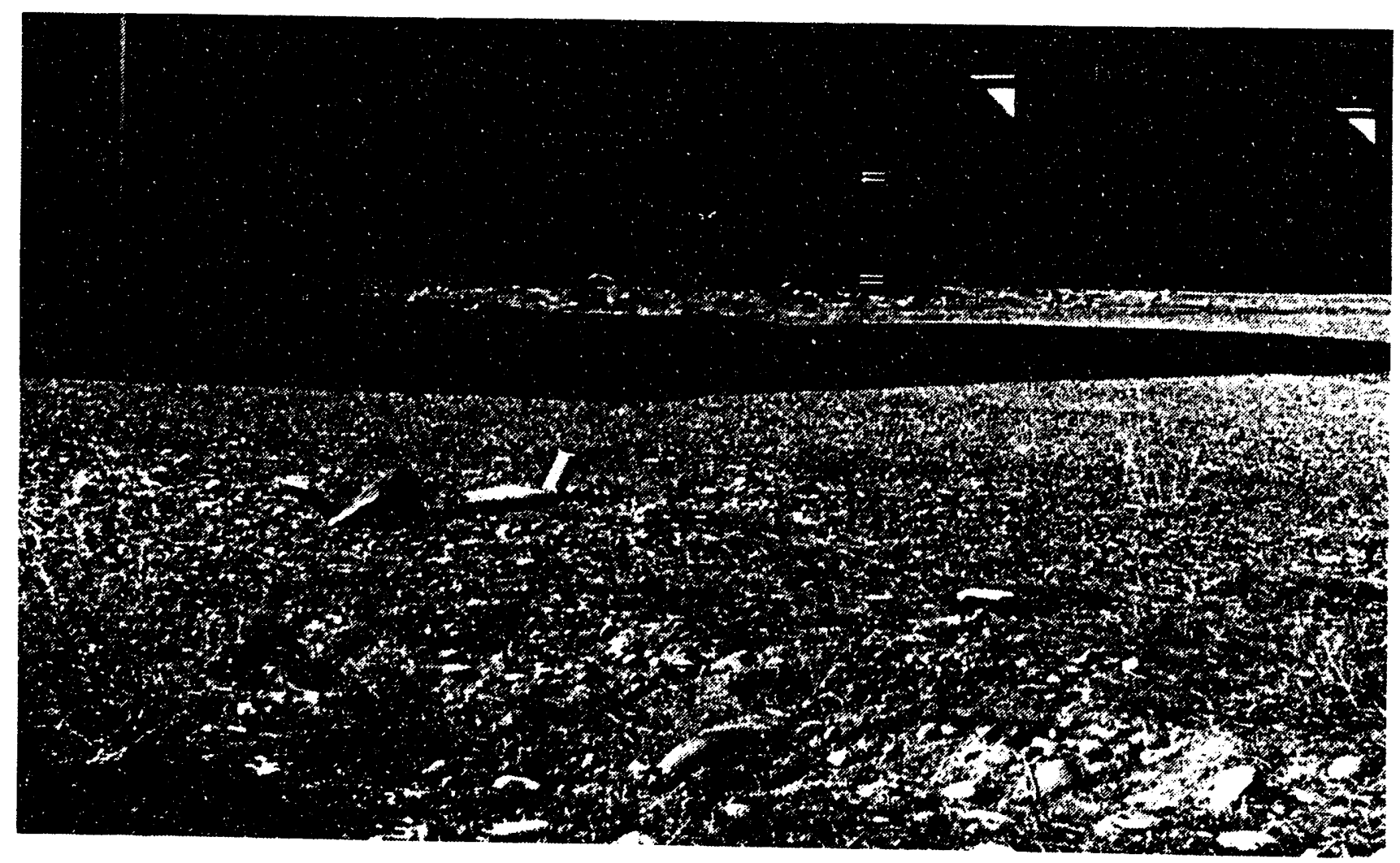

There is construction-type debris (wood, metal, cables, transite pipe, and concrete) on the surface of this trench as well as hazardous waste materials (small batteries and battery packs). It is unknown if any other hazardous materials were discharged at this site, although there is potential for chromate contamination in runoffs due to sodium dichromate additions to reactor cooling water and contamination of the soils located in the 190-DR tank pit area (Appendix D, D-11).

\subsection{0-D侮-1 AREA SITE DESCRIPTIONS AND BUILDING DIRECTORY}

This section describes facilities and areas not mentioned in the preceding sections. Some of these facilities may be important from a waste standpoint and are identified in Table 4-8, which identifies facilities that have potential for hazardous or radioactive material contamination. Table 4-9 provides a list of facilities and comments concerning the known disposition of various sites and facilities not previously mentioned. Not all facilities are included; mobile office trailers and other temporary construction buildings are not listed. Facility descriptions are summarized in Tables 4-8 and 4-9, and detailed descriptions are given for those facilities denoted by an asterisk. 
WHC-SD-EN-TI-181, Rev. 0

Table 4-8. Potentially Contaminated Facilities.

\begin{tabular}{|c|c|c|}
\hline FACILITY & $\begin{array}{l}\text { HANFORD } \\
\text { LOCATION }\end{array}$ & COMMENTS \\
\hline $108-D$ & $\begin{array}{l}\text { N92830 } \\
\text { W52800 } \\
\end{array}$ & $\begin{array}{l}\text { Mechanical Development Laboratory lab space for special tool } \\
\text { development and decontamination. The facility has been demol ished } \\
\text { and the aboveground portions buried in the } 184.0 \text { Coal Pit }\end{array}$ \\
\hline $119-0$ & & Reactor Exhaust Air Sample Building \\
\hline $181-D^{\star}$ & $\begin{array}{l}\text { N92725 } \\
\text { W56050 }\end{array}$ & River Pump House \\
\hline $182-D^{*}$ & $\begin{array}{l}\text { N92350 } \\
\text { W54880 }\end{array}$ & $\begin{array}{l}\text { Reservoir and Pumphouse, including miscellaneous buildings near } \\
182-D \text { that no longer exist }\end{array}$ \\
\hline $183-D^{\star}$ & $\begin{array}{l}\text { N92275 } \\
\text { W54275 } \\
\end{array}$ & $\begin{array}{l}\text { Filter Plant, Head House, Chemical Building, Flocculation and } \\
\text { Subsidence Basins, and Clearwells }\end{array}$ \\
\hline $185-D^{*}$ & $\begin{array}{l}\text { N92230 } \\
\text { W53775 }\end{array}$ & $\begin{array}{l}\text { Contained Mechanical Development, Shop facilities, and Thermal } \\
\text { Hydraulic Labs. Potential contaminants include solvents, paints, } \\
\text { and radioactive contaminants }\end{array}$ \\
\hline 189-D & $\begin{array}{l}\text { N92230 } \\
\text { W53380 }\end{array}$ & $\begin{array}{l}\text { Was attached to and considered a part of } 185 / 189-0 \text {. A storage pad } \\
\text { west of the facility is considered a part of the facil ity. The } \\
\text { storage pad is surrounded by a } 6-\mathrm{ft} \text { metal fence and includes a } \\
\text { gas cyl inder storage dock. This area is currently being used to } \\
\text { store Environmental Restoration Program Investigation Derived } \\
\text { Hastes. Nearby to the northeast is a subsidence area that can be } \\
\text { seen in Figures } 4-57 \text { and } 4-58\end{array}$ \\
\hline $190-0$ & $\begin{array}{l}\text { N92230 } \\
\text { W53225 } \\
\end{array}$ & Was attached to and considered a part of $185-D / 189-D$ \\
\hline 1714-D & $\begin{array}{l}\text { N93135 } \\
\text { W53220 } \\
\end{array}$ & $\begin{array}{l}\text { Solvent Storage. It is unknown if spills occurred or what sol- } \\
\text { vents were stored }\end{array}$ \\
\hline $1715-D$ & $\begin{array}{l}\text { N93135 } \\
\text { W53320 } \\
\end{array}$ & $\begin{array}{l}\text { Oil and Paint storage. It is unknown if spills occurred or what } \\
\text { materials were stored }\end{array}$ \\
\hline $1716-D$ & $\begin{array}{l}\text { N92875 } \\
\text { W53550 }\end{array}$ & $\begin{array}{l}\text { Automobile Repair and Service Shop. There is potential for sol- } \\
\text { vents, gasol ine, bottery and automotive coolants in the soil } \\
\text { around the facility and in drains }\end{array}$ \\
\hline $1722-D$ & $\begin{array}{l}\text { N93010 } \\
\text { W53190 }\end{array}$ & $\begin{array}{l}\text { Paint Shop and Riggers Loft. Potential for solvents and paint } \\
\text { contamination in the soil and drains at the facility }\end{array}$ \\
\hline
\end{tabular}


WHC-SD-EN-TI-181, Rev. 0

Figure 4-57. Subsidence Near the 189-D Storage Pad.

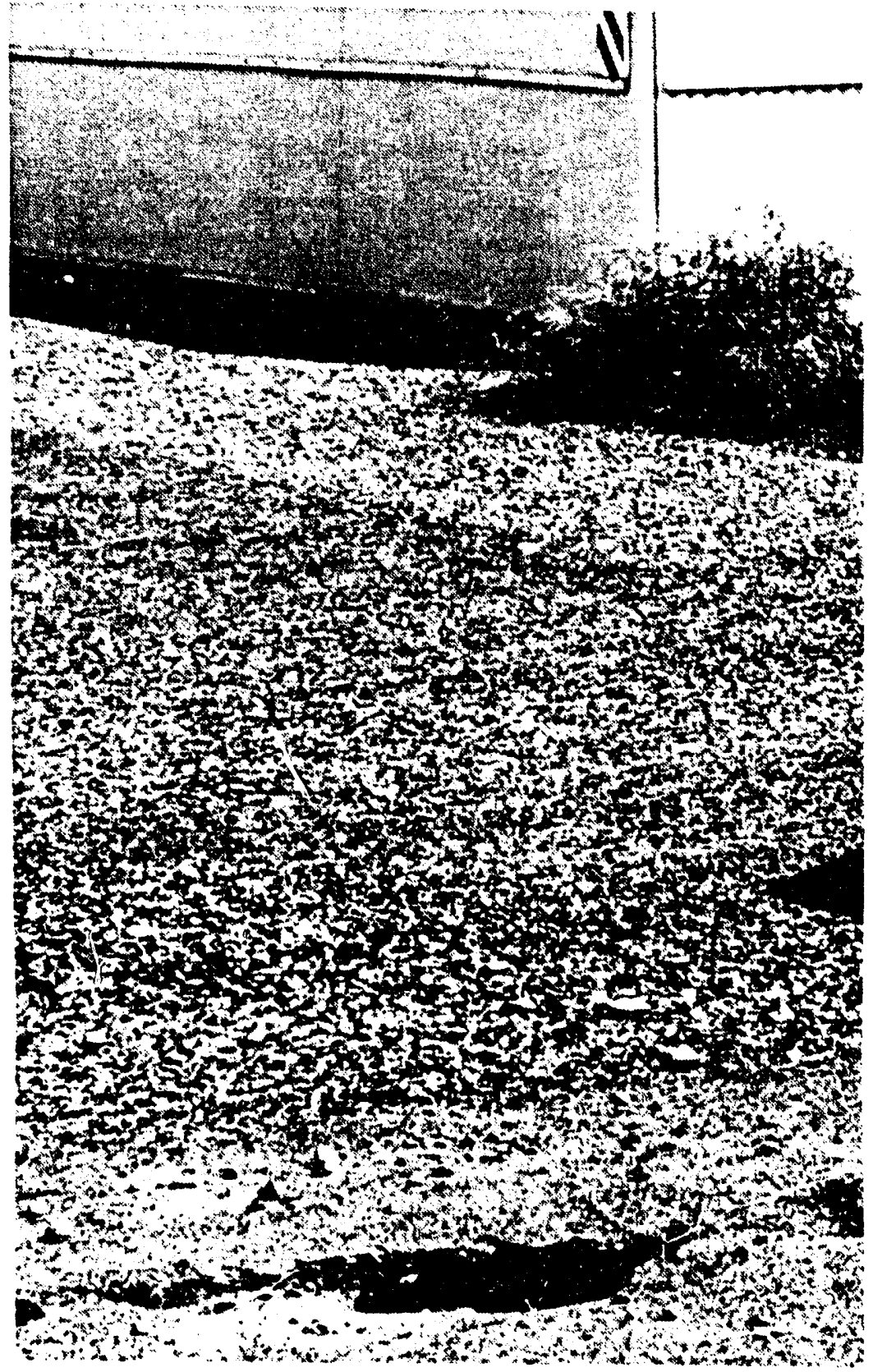

Figure 4-58. Detail of Figure 4-57.

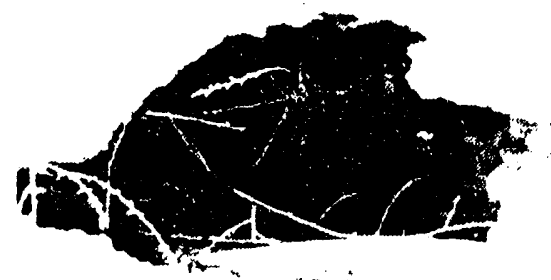


* 181-D River Pump House

The facility was used to pump raw river water to the 100-D reservoir for use by the 100-D Reactor. The facility was modified in 1950 to provide for the additional demand for cooling water as a result of the decision to operate the 105-D and 105-DR Reactors simultaneousiy.

In May 1964, one of the river pumps was removed for disassembly and maintenance. Radiation survey with a portable GM counter revealed that the interior surfaces of the pump were contaminated with radioactive material with counts of 1,500 to $2,000 \mathrm{c} / \mathrm{m}$. The radioactivity was allowed to decay and readings were taken again in two months and found to be $200 \mathrm{c} / \mathrm{m}$. Al so in May of 1964, the stator of one pump was removed for maintenance. A smear of the loose material on the windings was obtained and counted with a portable GM counter and also allowed to decay for a period. The results can be seen in the following list.

$$
\begin{array}{rr}
5-27-64 & 8,000 \mathrm{c} / \mathrm{m} \\
6-08-64 & 300 \mathrm{c} / \mathrm{m} \\
6-17-64 & 400 \mathrm{c} / \mathrm{m}
\end{array}
$$

No reason was given for the increase in activity between the two June dates. A gamma spectrum scan of the pump stator was run for five minutes on a multi-channel analyzer with the following results: on June $18,1964{ }^{144} \mathrm{Ce}$ and ${ }^{137} \mathrm{Cs}$ were present, together with other less distinguishable energy peaks (Copeland 1964). As a result of these radiological investigations, any decommissioning activities should consider the possibility of radioactive contamination on the interior surfaces of piping systems, valves, and pumps.

Contamination could potentially exist in the pit used to back flush the filter screens. This is unlikely, however, because the contaminants found earlier were a result of effluents discharged from reactors located upstream of this facility. The discharge pit was not in place prior to 1975, nearly ten years after all but $N$-Reactor had been shut down (Figure 4-59).

Prior to installation of the discharge pit, untreated river water that was used to dislodge and backflush material from the pump inlet screens was returned to the river via a 12-in. steel pipeline that discharged north of the facility on the river bottom about $100 \mathrm{ft}$ from shore (ERDA 1975).

A second 14-in. discharge pipe terminates about $200 \mathrm{ft}$ upstream of the facility at a concrete flume that is about $20 \mathrm{ft}$ wide and extends to the river bank. The discharge pipe's end is capped and the pipe wall has had small holes drilled over the top surface along the entire length of the flume. It appears that it is connected to the barometric condensers. According to site personnel, it is a condenser discharge pipe (Hanford Drawing W-73564) (Figures 4-60 and 4-61).

The facility is currently used as backup to the B-Area export water system. Portions of it are deactivated and some equipment has been removed. 
Figure 4-59. Filter Backwash Trench.

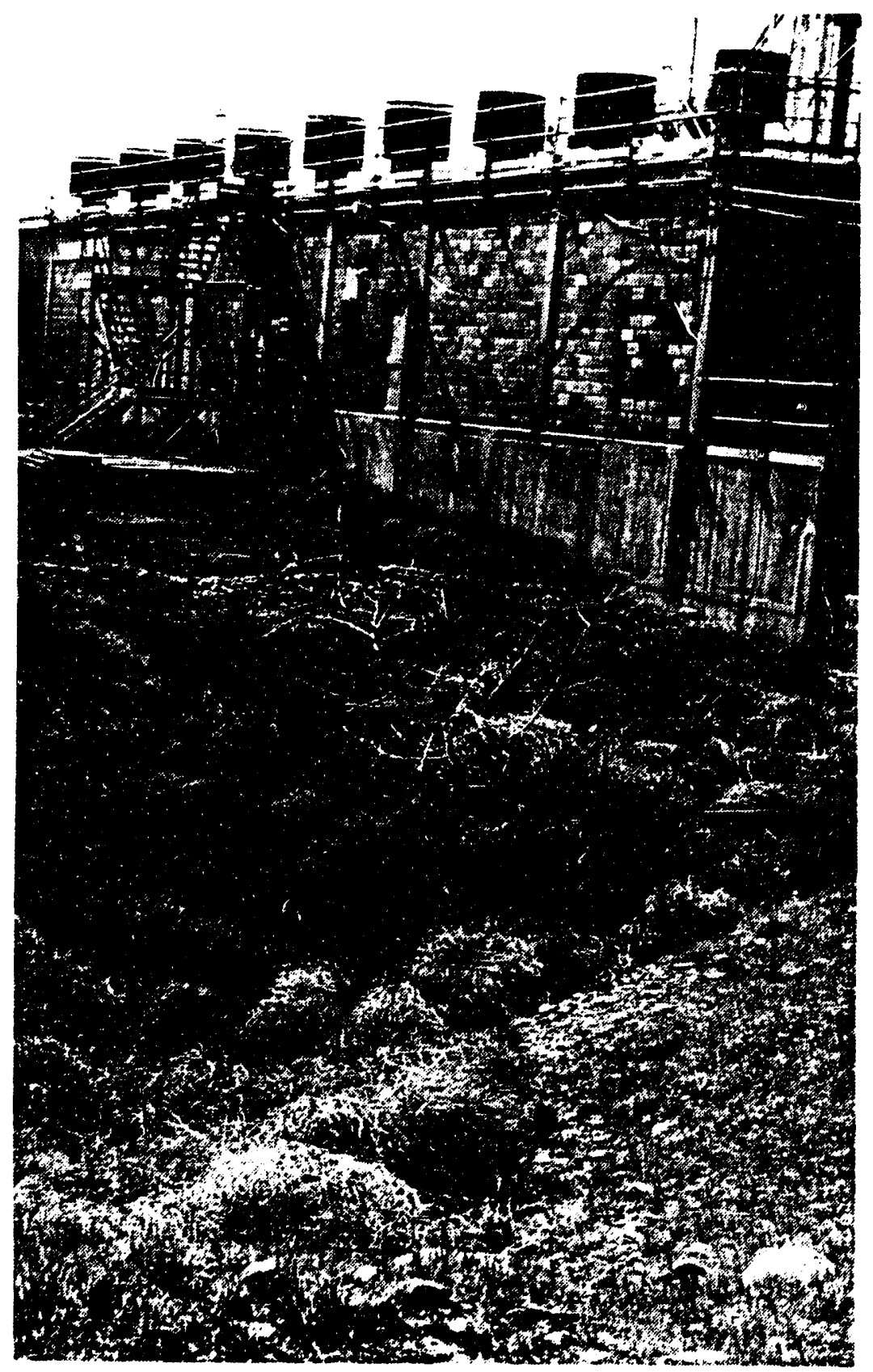

* 182-D Reservoir and Pump House

In 1950, modifications were performed to supply backwash water to the 105DR water treatment facilities, and a crosstie was added for the backup water supply needs of the 105-DR water treatment facilities.

The facility is currently used as a backup to the B-Area export water system. Most of the equipment remains in place, but portions of the facility, such as the alum makeup and addition facilities, have been deactivated. Two pumps remain in service to backup the export water system. 
WHC-SD-EN-TI-181, Rev. 0

Figure 4-60. Flume Upstream of the 181-D Pumphouse.

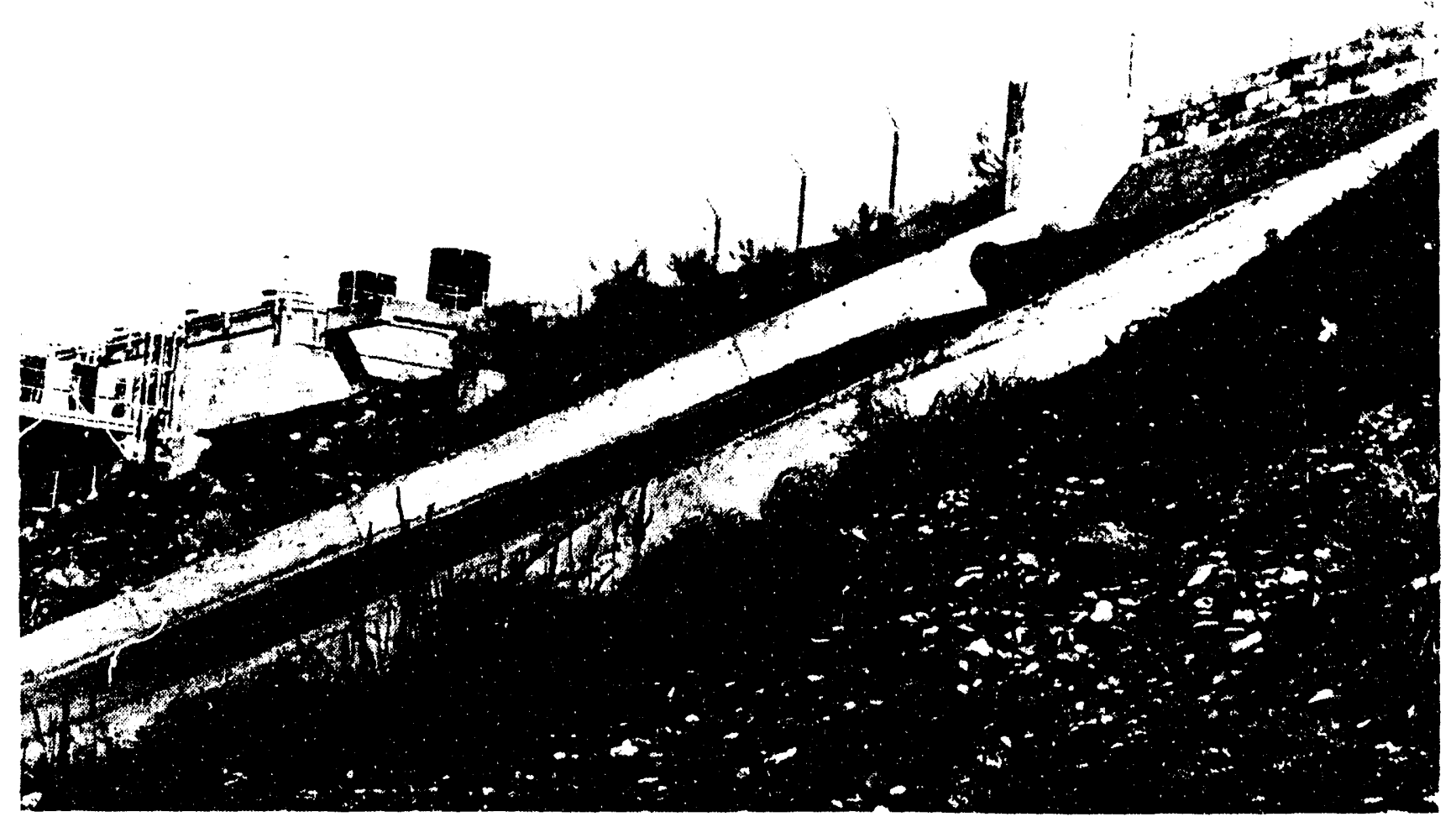

Figure 4-61. Pipe in the Flume Upstream of the 181-D Pumphouse.

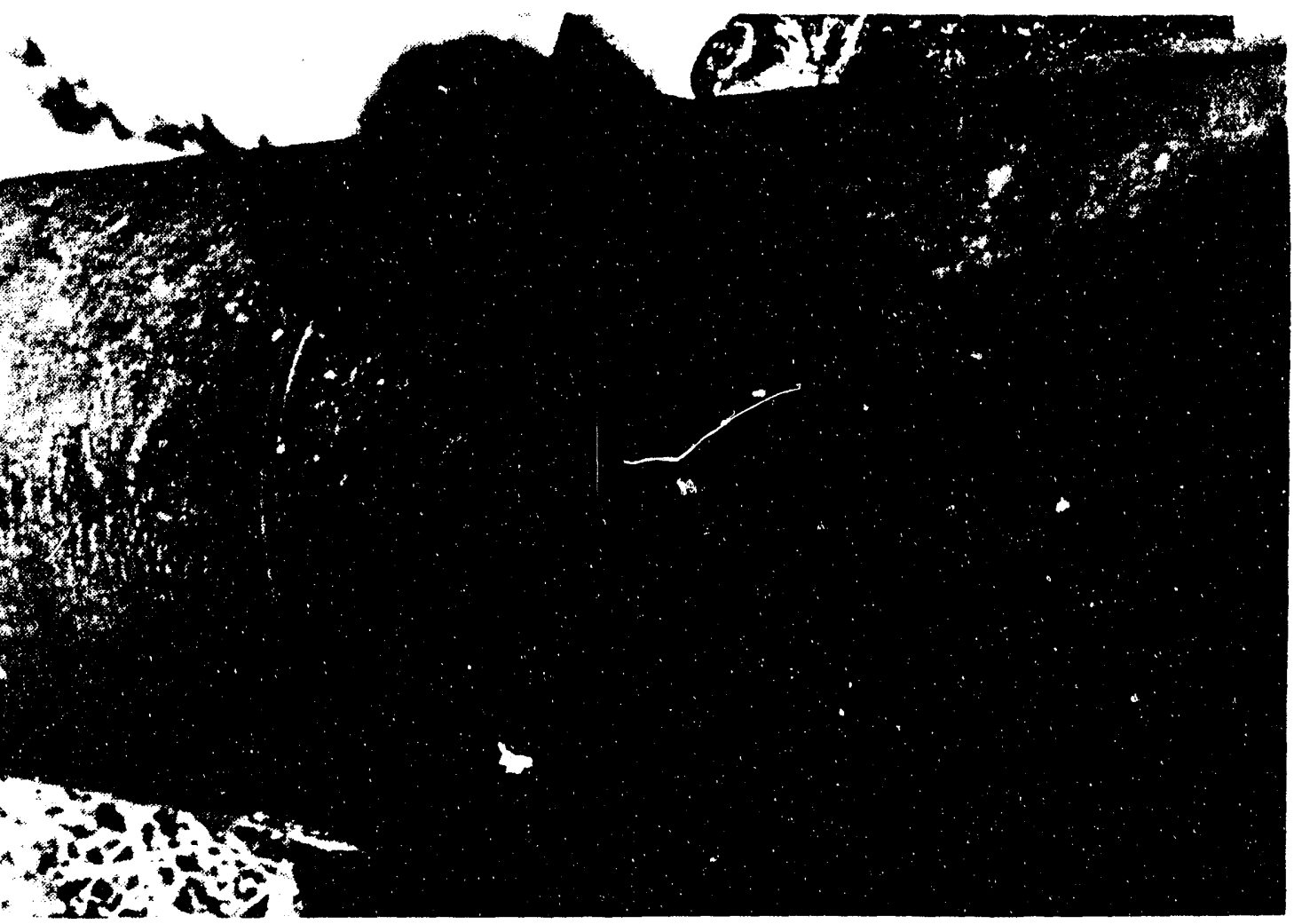




\section{* Miscellaneous Buildings Located Near 182-D}

A building labeled "Paint Shop" was located on site drawings west of the 182-D reservoir, Hanford coordinates $N 92425$ W55330. Other buildings were also noted at the approximate location in photographs. These buildings are shown in Figure 2-2 of DOE/RL 1992.b and are labeled as a Temporary Labor Office, Hanford coordinate location N92505 W55300, and as a Temporary Pipe Shop, Hanford coordinate location N92300 W55325. Another facility shown in Figure 2-2 of DOE/RL 1992b, located southwest of the 182-D reservoir at Hanford coordinates $\mathrm{N} 91990$ W55340, is described as the 1722-DA Electric Shop. No documentation has been found concerning these facilities or the materials stored there (DOE/RL 1992b).

\section{* 183-D Filter Plant, Head House, Chemical Building, Flocculation and Subsidence Basins, Filter Building, and Clearwells}

The facility is currently used as a backup to the B-Area export water system. Only two sections of the flocculation basin remain in service. They provide sanitary water to the remaining occupied facilities at $100-\mathrm{F}, 100-\mathrm{H}$, and 100-D Areas (includes fire lines). A single pump serves this water supply. The large sulfuric acid storage tanks located to the southwest of the facility adjacent to the clearwells have been removed. Much of the piping
remains in place.

Beneath the concrete cradles for the acid storage tanks there is a small concrete trench drainage system, approximately 12 by 12 by $120 \mathrm{ft}$ long. In the center, between the tank cradles, there is a large sump with a french drain in the bottom made of $3-\mathrm{ft}$-diameter vitreous clay pipe (see Hanford at the location for details). The concrete trench and associated equipment (Figure 4-62).

In May 1964, a filter backwash valve, located on the clean water side of the filter, was removed for maintenance. There were no detectable contamination levels found using portable GM counter equipment (Copeland 1964). The lack of contamination at this point in the system indicates that contaminants contained in the raw river water were likely trapped in the filter media or flocculent used to pretreat the water.

\section{* 185-D Water Treatment Facilities and Combined Shops}

During operations, this facility housed the sodium dichromate addition mix tank, pumps, and storage facilities for the 105-D Reactor. The sodium dichromate could be made from either dry bagged or liquid materials. These were transferred from either rail tank cars or truck tank cars at a pumping stion located just south of the 184-D Building. A 3-in. underground line connected the sodium dichromate storage facilities, located in the 183-DR head house, to within the 100-DR-2 and the 185-D facilities. The pumping station is located Section 5.15 . 
Figure 4-62. Acid Tank Cradles and Drain Trench Near 192-D.

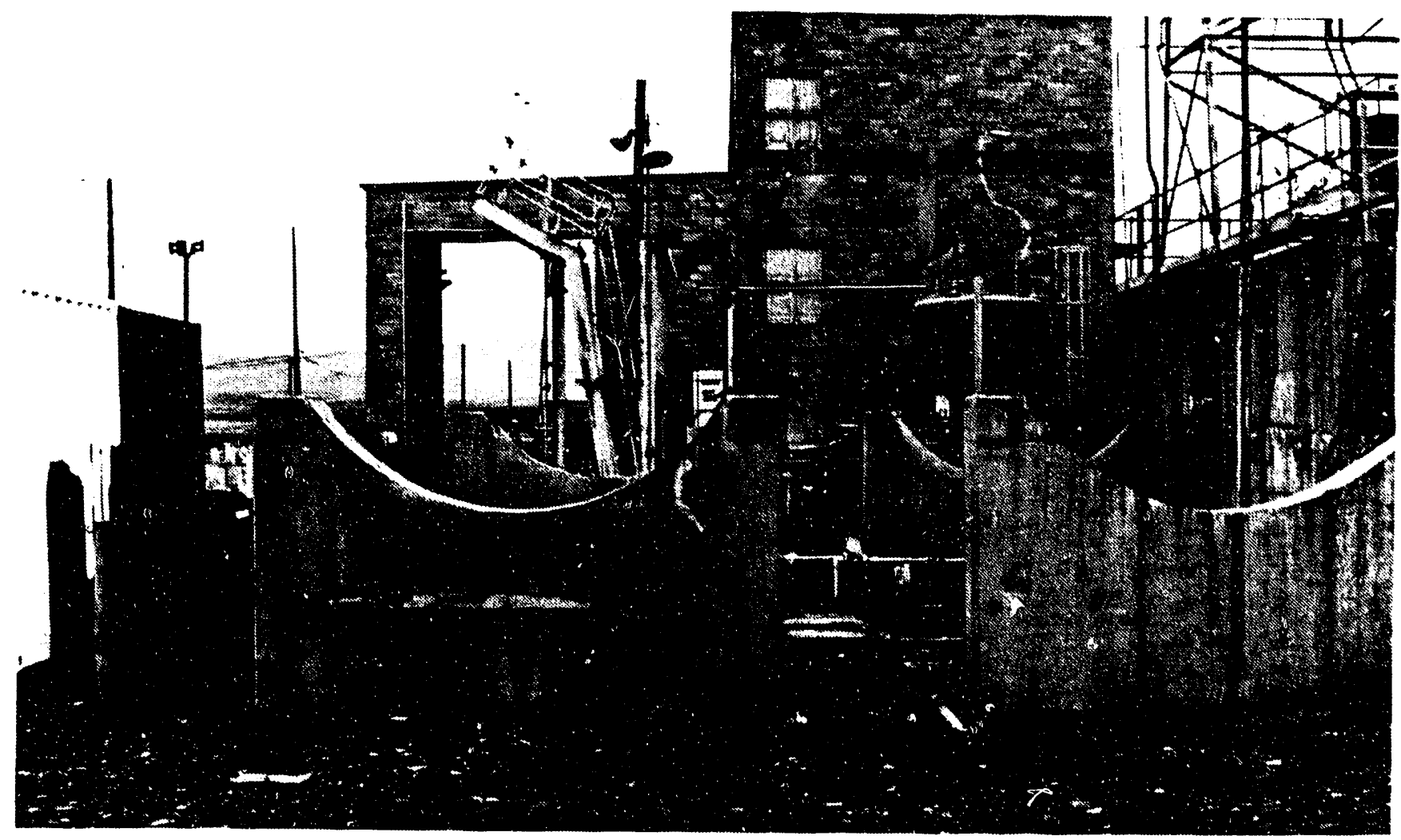

After making the sodium dichromate, the mixing tank facilities and, when otherwise needed, the sodium dichromate system, were cleaned and drained through the building drain to the process sewer and to the river via the 1904D outfall.

Originally, these facilities were connected to the sodium dichromate storage facilities located just west of the 108-D Building by a 3-in. underground line. It is unknown why the transfer station was relocated to the south of the 184-D Facility.

Table 4-9. Low Potential for Contamination Facilities.

\begin{tabular}{|c|c|c||}
\hline FACILITY & $\begin{array}{c}\text { HANFORD } \\
\text { LOCATION }\end{array}$ & \multicolumn{1}{|c|}{ COMMENTS } \\
\hline $110-D$ & $\begin{array}{l}\text { N91680 } \\
\text { W52680 }\end{array}$ & $\begin{array}{l}\text { Gas storage Facility. Demol ished in } 1986 \text { inclusive of concrete } \\
\text { pods and sheet metels, disposed of in area landfill }\end{array}$ \\
\hline $184-$ & $\begin{array}{l}\text { N93180 } \\
\text { W53875 }\end{array}$ & $\begin{array}{l}\text { Powerhouse was identical to 184-8. It was modified in 1950 to } \\
\text { supply the 105-DR facilities, odding the distinctive third exhaust } \\
\text { stack }\end{array}$ \\
\hline $186-D$ & $\begin{array}{l}\text { N92225 } \\
\text { W53775 }\end{array}$ & $\begin{array}{l}\text { Originally to be used for water treatment but never used as such. } \\
\text { Was used as a warehouse }\end{array}$ \\
\hline
\end{tabular}


WHC-SD-EN-TI-181, Rev. 0

\begin{tabular}{|c|c|c|}
\hline $187-D$ & $\begin{array}{l}N 92875 \\
W 53910 \\
\end{array}$ & Elevated Water Tank \\
\hline 188-D & $\begin{array}{l}\text { N93870 } \\
\text { W53750 } \\
\end{array}$ & Ash Disposal Basin (126-D-1) \\
\hline $195-D$ & $\begin{array}{l}N 92075 \\
W 53425 \\
\end{array}$ & $\begin{array}{l}\text { Vertical Safety Rod Tower. Used for rod tests and channel inspec- } \\
\text { tion training }\end{array}$ \\
\hline $1605-D$ & $\begin{array}{l}N 92725 \\
W 56050 \\
\end{array}$ & Guard Tower. Located above $181-D$, has been taken down \\
\hline $1606-D$ & & Settling Tanks. Data found in HW-5000, no additional information \\
\hline $1701-D A$ & $\begin{array}{l}N 92525 \\
\text { W52910 } \\
\end{array}$ & Badgehouse to $105-D$ exclusion area \\
\hline 1703-D & $\begin{array}{l}N 92790 \\
W 53050 \\
\end{array}$ & Technical office Building \\
\hline 1704-D & $\begin{array}{l}\text { N92825 } \\
\text { W53275 } \\
\end{array}$ & Office Building \\
\hline $1707-D$ & $\begin{array}{l}\text { N92875 } \\
\text { W53075 }\end{array}$ & Changehouse \\
\hline 1707A-D & $\begin{array}{l}\text { N93000 } \\
\text { W53550 } \\
\end{array}$ & Maintenance Changehouse \\
\hline $\begin{array}{l}1713-D \\
1712-D\end{array}$ & $\begin{array}{l}\begin{array}{l}N 93030 \\
\text { W53075 }\end{array} \\
\end{array}$ & Storeroom and Warehouse. 1712-D is at tached to $1713-0$ \\
\hline 1713-DA & $\begin{array}{l}N 93710 \\
W 54340 \\
\end{array}$ & Warehouse and storage, essential materials \\
\hline $1717-D$ & $\begin{array}{l}\text { N93025 } \\
\text { W53350 } \\
\end{array}$ & $\begin{array}{l}\text { Area Maintenance and offices, Usable portions sold, foundation, } \\
\text { floor, roof, and siding disposed of in } 184-0 \text { coal pit }\end{array}$ \\
\hline 1719-D & $\begin{array}{l}\text { N92875 } \\
\text { W53380 } \\
\end{array}$ & $\begin{array}{l}\text { First Aid. Usable portions sold, foundation, floor, roof, and } \\
\text { siding disposed of in } 184-D \text { Coal } P \text { it }\end{array}$ \\
\hline $1724-D$ & $\begin{array}{l}N 91925 \\
W 53140 \\
\end{array}$ & Underwater Test facility. Attached to $190-\mathrm{D}$ on southeast side \\
\hline $1734-D$ & $\begin{array}{l}N 93130 \\
W 53410 \\
\end{array}$ & $\begin{array}{l}\text { cylinder storage. Cylinder storage types unknown, the facility had } \\
\text { been demol ished }\end{array}$ \\
\hline $1760-D$ & $\begin{array}{l}\text { N92700 } \\
\text { W53050 } \\
\end{array}$ & office Building \\
\hline 1784-D & & Coal Handler Building \\
\hline $1821-D$ & & $\begin{array}{l}\text { Emergency Generator Building. The gasol ine engine and fuel tank } \\
\text { have been removed }\end{array}$ \\
\hline
\end{tabular}


* 184-D Powerhouse

Constructed in 1943, the 184-D Powerhouse was identical to the 184-B Building except that it contained five boilers. The boilers each had three $300-\mathrm{ft}$ exhaust stacks and a 290 ton capacity coal bunker that fed, by gravity, into a stoker-feeder hopper serving five steam turbine stokers. The powerhouse also included a coal handling conveyer system and a sump and wet ash disposal system. The coal used at the powerhouse was unloaded from railcars into two below-grade hoppers and conveyed through a $155-\mathrm{ft}$ concrete tunnel.

In 1950, The 184-D Powerhouse was extended and modified to accept the fifth boiler, which was added as a result of the decision to operate the 100-D and 100-DR Reactor facilities simultaneously. This expansion added the distinctive third exhaust stack to the powerhouse.

The coal hoppers, tunnel, and crusher house pit were filled to grade with soil when the facility was decommissioned. The tunnel roof was left intact and the tunnel partially backfilled with rubble. Asbestos was removed to the 200 Area central landfill. Some fragments of transite siding were irretrievable from the tunnel and were left mixed with the other demolition rubble in situ; all transite is buried deeper than $3 \mathrm{ft}$. Before the area was graded and backfilled, additional holes were punched in the tunnel, pits, and tank bottoms to provide for drainage, and rubble was worked into position to reduce voids and minimize future subsidence. Demolition activities were completed March 29, 1988. The area was covered to match the surrounding area with a minimum of $3 \mathrm{ft}$ of clean backfill in accordance with requirements of UNI-M-31, Environmental Control Manual (Griffin 1988).

The site appears today as a cobble- and ash-covered field with natural grasses and vegetation beginning to be reestablished. 


\subsection{0-DR-2 OPERABLE UNIT}

This section describes the 100-DR-2 Operable Unit, which encompasses the area to the south of the 100-DR-1 Operable Unit and is bounded on the scuth by the north boundary of the 100-DR-3 Operable Unit. The eastern boundary generally follows the 100-D Area exclusion area fence just east of the 105-DR Reactor building. It includes the 100-DR Reactor and water treatment facilities and the main Electrical Substation (151-D) located in the 100-D/DR Area. It encompasses 16 waste sites, 7 of which are included in the Tri-Party Agreement (Ecology et al. 1989). These include decommissioned and active facilities, trenches, cribs, french drains, septic tanks, burial grounds, and unplanned releases (Appendix E).

The relative locations of 100-DR-1, 100-DR-2, and 100-DR-3 are shown in Appendix $B(B-3)$. A map of the 100-DR-2 Operable Unit can al so be found in Appendix $B(B-5)$. Additional figures $(B-7, B-8, B-9$, and $B-10)$ are included in Appendix $B$ to provide clarity for each waste type described.

Table 5-1 identifies the sites for which a PNL HRS Migration Score has been established; not all of the waste sites located within the 100-DR-2 Operable Unit have had HRS scores applied to them.

Table 5-1. Hazard Ranking System Migration Score.

\begin{tabular}{|c|c|}
\hline WASTE SITE NUMBER & HRS MIGRATION SCORE \\
\hline $116-D R-3$ & 40.09 \\
\hline $116-D R-4$ & 9.13 \\
\hline $116-D R-6$ & 42.32 \\
\hline $116-D R-7$ & 28.96 \\
\hline $116-D R-8$ & 0.00 \\
\hline $118-D-5$ & 1.84 \\
\hline
\end{tabular}

(Stenner et al 1988)

Each waste site is described separately in Sections 5.1 through 5.16.

\subsection{6-D-8 (100-D CASK STORAGE PAD)}

The 116-D-8, located at Hanford coordinates N91200 W53000 (WHC 1991), is an inactive solid waste site that operated from 1946 to 1975 . It is a concrete pad with two drains that was used to store shipping and handling casks when they were not in use. One of the drains facilitated rain runoff and the disposal of minor decontamination solutions and drained into the 105DR process sewer (WHC 1991). The second drain was for decontamination use and discharged to a french drain. The location of the french drain is currently unknown, although a photograph taken in December 1949 shows the construction of a trench and pit that could be the drain (Figure 5-1). It was al so thought that the french drain was located beneath the loading dock floor on the west side of the pad. 
Figure 5-1. Cask Pad, Suspect French Drain Addition, 1949.

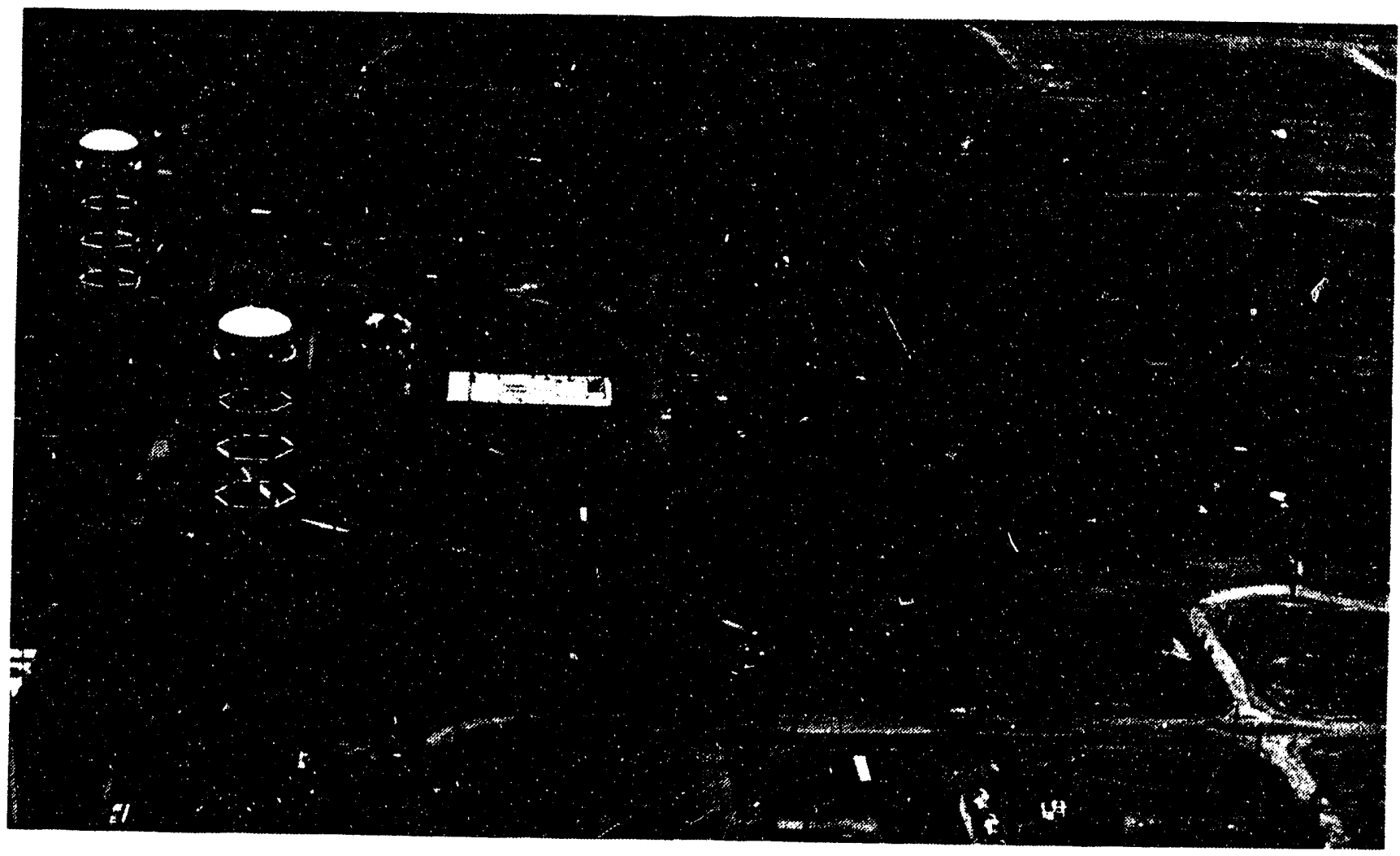

A11 casks were removed, and the surface contamination, consisting of trace amounts of radionuclides and decontamination chemicals, was fixed to the concrete with an asphalt emulsion coating. Four depressions on the pad have been filled with gravel. Two of these depressions, located at the approximate center of the pad, are small rectangular pits lying parallel to each other, about $2 \mathrm{ft}$ wide and 6 to $8 \mathrm{ft}$ long. These two pits have been described as decontamination basins. It is believed that these two pits drained to the previously mentioned french drain.

A larger pit on the west side of the cask pad was a loading dock that also drained to the french drain. The final gravel-filled location has an irregular shape and is located just south of the two small decontamination pits. Site employees report that the concrete in this area was removed due to excessive contamination, and gravel was added to bring the resulting hole up to grade.

Located about $15 \mathrm{ft}$ south of the cask pad is an underground pipe tunnel containing cooling water pipes that originate in the 190-DR Building. The area (approximately 15 by $80 \mathrm{ft}$ ) between this pipe tunnel and the cask pad is surrounded by a light weight chain and steel fence-post barricade that is marked with Underground Radioactive Material warning signs. Site employees report that this area had been contaminated by runoff and leachates due to spills that occurred during operations. Additional soil was added to this area in 1991 during the latest decontamination effort. 
Two large structures were moved to the south end of the pad from some other location. One is a tank, about $12 \mathrm{ft}$ tall by $10 \mathrm{ft}$ in diameter, that is labeled "Alum Storage" and has Internal Radioactive Material warning stickers attached to the surface. The other, about $8 \mathrm{ft}$ tall by $10 \mathrm{ft}$ in diameter, appears to be a furnace (Figure 5-2).

Figure 5-2. 100-D Cask Pad, Early 1993.

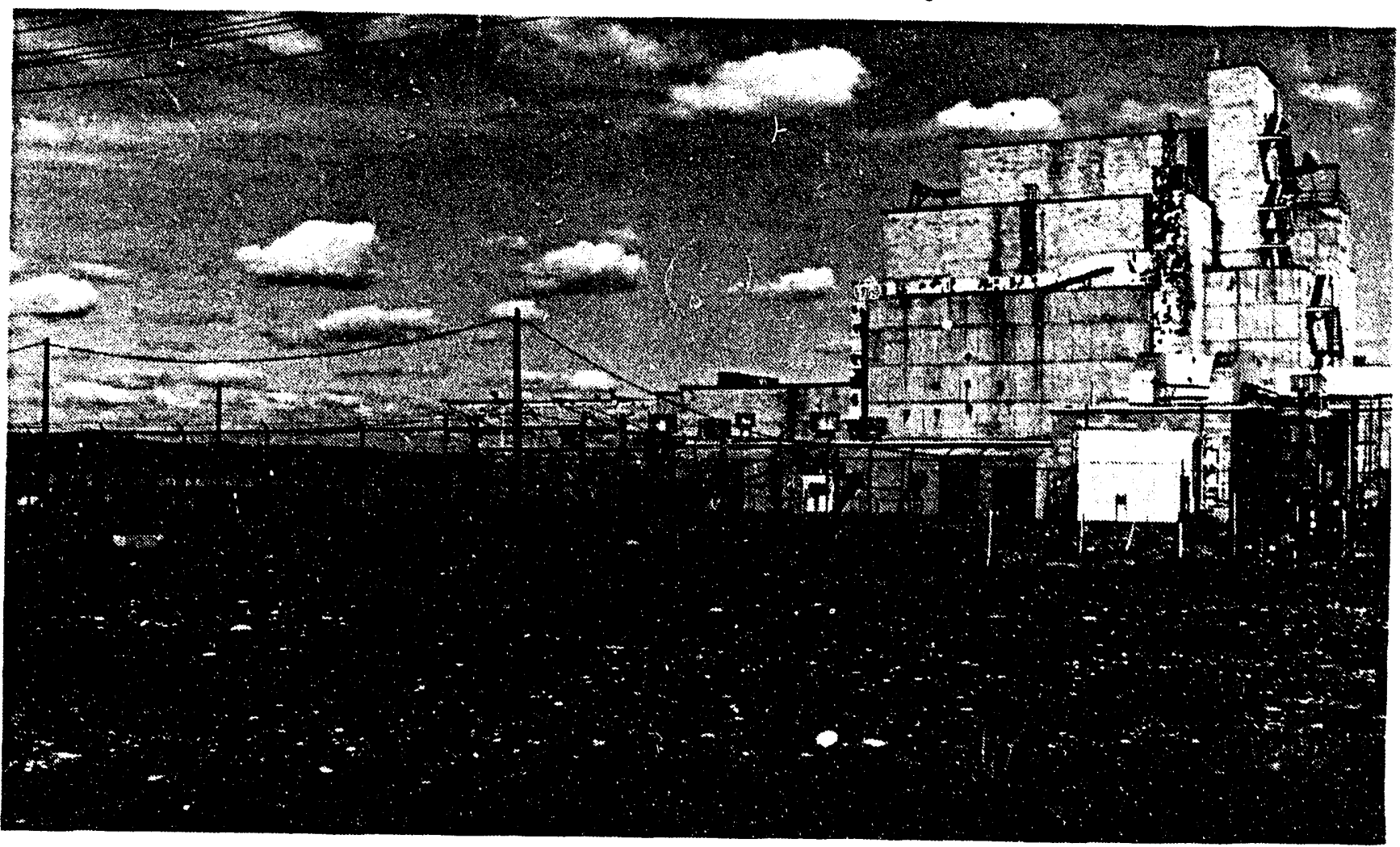

Located to the rear of the pad (west side) are two concrete support structures. They once supported a small hoist attached to the construction facility that was located at the site during construction of the DR Reactor.

The 8-ft fence that once surrounded the pad has recently been removed in preparation for the installation of a bio-barrier and concrete covering. These will eliminate surface contamination leaching problems associated with past contamination of the pad.

This waste site has not been assigned an HRS Migration score.

\subsection{6-DR-3 (105-DR STORAGE BASIN TRENCH)}

The 116-DR-3 is an inactive liquid waste site that operated during 1955 . The trench is located at Hanford coordinates $N 90900$ W52600, which is $150 \mathrm{ft}$ east of 117-DR Building. This $60-$ by $40-$ by $10-\mathrm{ft}$-deep trench received contaminated sludge and water removed from the 105-DR fuel storage basin (WHC 1991). 
It received an estimated $4,000,000 \mathrm{~L}$ of waste. The radionuclide inventory in curies decayed through April 1, 1986 includes the following:

$\begin{array}{ll}{ }^{60} \mathrm{Co}: & 1.010 \mathrm{e}-002 \\ { }^{134} \mathrm{Cs}: & 1.000 \mathrm{e}-005 \\ { }^{137} \mathrm{Cs}: & 3.560 \mathrm{e}-002\end{array}$

$\begin{array}{cc}{ }^{152} \mathrm{Eu}: & 1.970 \mathrm{e}-002 \\ { }^{154} \mathrm{Eu}: & 3.090 \mathrm{e}-003 \\ 3_{\mathrm{H}} \mathrm{2} & 2.080 \mathrm{e}-001\end{array}$

239 $\mathrm{pu}: \quad 2.970 \mathrm{e}-003$

$240 \mathrm{Pu}: \quad 3.300 \mathrm{e}-004$

${ }^{90} \mathrm{Sr}: \quad 5.150 \mathrm{e}-002$

(Stenner et al 1988)

Additionally, Dorian and Richards (1978) reports the results of soil samples taken from four locations in the trench. It reports the trench volume as $3.6 \times 10^{4} \mathrm{ft}^{3}$ and the mass as $2.5 \times 10^{9} \mathrm{~g}$. The full tables are provided in Appendix $C$ and are summarized in Tables 5-2 and 5-3. Compare the "Curies" column to the Stenner et al (1988) data provided above.

Table 5-2. 116-DR-3 Radionuclide Inventory.

\begin{tabular}{||c|c|c|}
\hline RADIONUCLIDE & AVE. $\mathrm{pCi} / \mathrm{g}$ & CURIES \\
\hline${ }^{238} \mathrm{Pu}$ & & 0.0 \\
\hline${ }^{239 / 240} \mathrm{Pu}$ & $1.30 \mathrm{E}^{+00}$ & $3.30 \mathrm{E}^{-03}$ \\
\hline${ }^{90} \mathrm{Sr}$ & $2.50 \mathrm{E}^{+01}$ & $6.30 \mathrm{E}^{-02}$ \\
\hline${ }^{3} \mathrm{H}$ & $1.30 \mathrm{E}^{+02}$ & $3.30 \mathrm{E}^{-01}$ \\
\hline${ }^{152} \mathrm{Eu}$ & $1.20 \mathrm{E}^{+01}$ & $3.00 \mathrm{E}^{-02}$ \\
\hline${ }^{60} \mathrm{Co}$ & $1.20 \mathrm{E}^{+01}$ & $3.00 \mathrm{E}^{-02}$ \\
\hline${ }^{154} \mathrm{Eu}$ & $2.40 \mathrm{E}^{+00}$ & $6.00 \mathrm{E}^{-03}$ \\
\hline${ }^{134} \mathrm{CS}$ & $7.00 \mathrm{E}^{-02}$ & $1.80 \mathrm{E}^{-04}$ \\
\hline${ }^{137} \mathrm{CS}$ & $1.70 \mathrm{E}^{+01}$ & $4.30 \mathrm{E}^{-02}$ \\
\hline${ }^{155} \mathrm{Eu}$ & $3.20 \mathrm{E}^{-01}$ & $8.00 \mathrm{E}^{-04}$ \\
\hline TOTAL CURIES & & $5.10 \mathrm{E}^{-01}$ \\
\hline
\end{tabular}

(Dorian and Richards 1978)

Table 5-3. 116-DR-3 Radionucl ide Inventory.

\begin{tabular}{||c|c|}
\hline RADIONUCLIDE & AVE. pCi/g \\
\hline $\begin{array}{l}\text { Ave. } \\
\text { Beta/Gamma }\end{array}$ & $1.70 \mathrm{E}^{+02}$ \\
\hline $\begin{array}{l}\text { Max. } \\
\text { Beta/Gamma }\end{array}$ & $3.10 \mathrm{E}^{+02}$ \\
\hline $\begin{array}{l}\text { Ave } \\
239 / 240 \mathrm{Pu}\end{array}$ & $1.30 \mathrm{E}^{+00}$ \\
\hline $\begin{array}{l}\text { Max. } \\
239 / 240 \mathrm{Pu}\end{array}$ & $3.80 \mathrm{E}^{+00}$ \\
\hline
\end{tabular}

(Dorian and Richards 1978) 
There is some question as to the exact location of this site. Hanford Drawing H-1-4046 shows it partly outside the present permanent concrete markers (site number 20 ). The trench is also described as being located at Hanford coordinates N91000 W52750 as a "grave" dug in November 1953 (a grave is a trench that is dug for a specific waste and buried soon after the waste is deposited) (Clukey 1956).

The site appears today as a vegetation-free, cobble- and soil-covered field within a larger area bounded by permanent concrete markers posted with Underground Radioactive Material warning signs (Figure 5-3).

This waste site has an HRS Migration score of 40.09 (Stenner et at 1988).

Figure 5-3. 105-DR Fuel Storage Basin Trench.

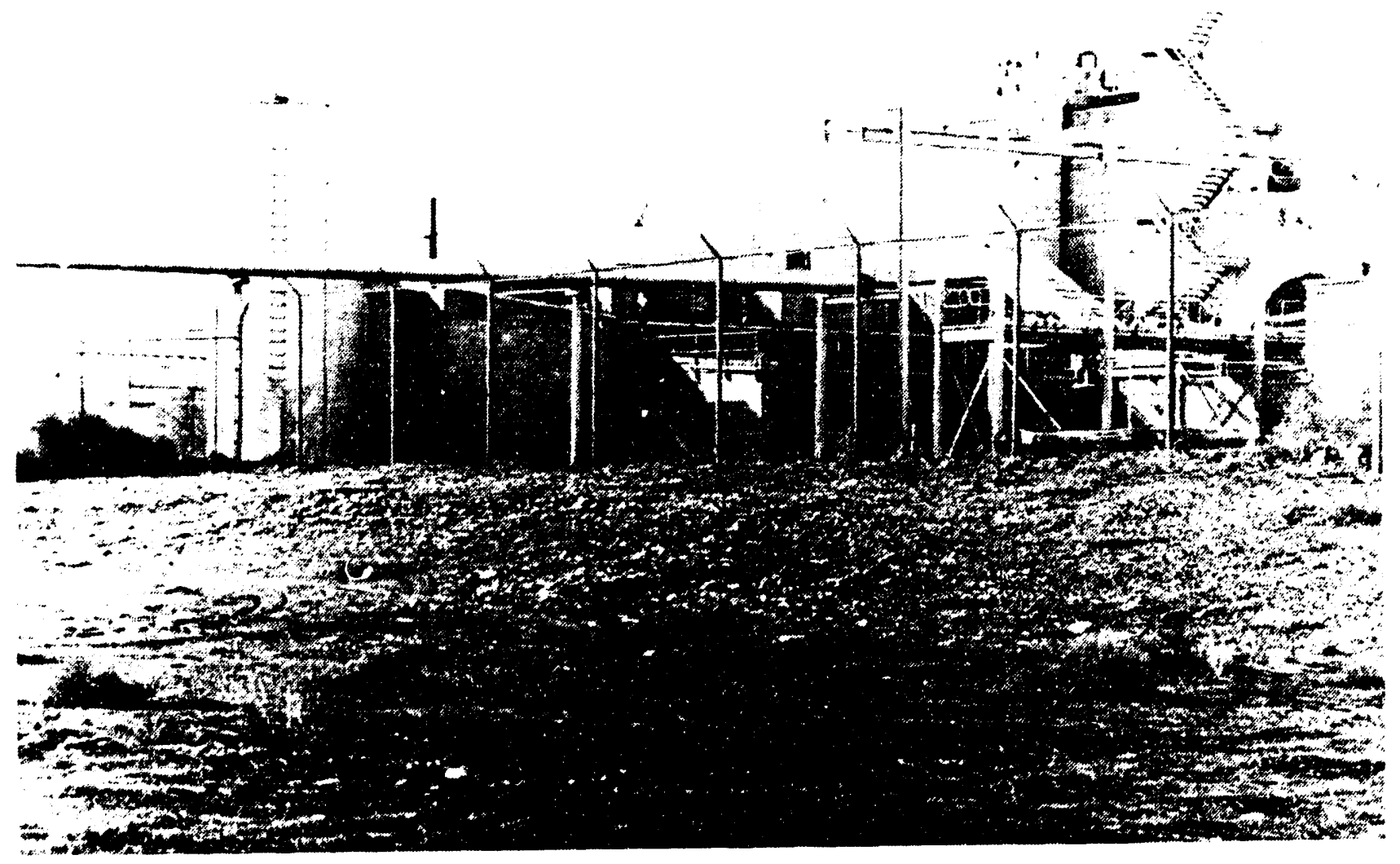

\subsection{6-DR-4 (105-DR PLUTO CRIB)}

The 116-DR-4 is an inactive liquid waste site that operated from 1950 (Heid 1956) to 1956 (ERDA 1975). The crib was located at Hanford coordinates N91025 W52600, which is $200 \mathrm{ft}$ southeast of the 105-DR Building (PNL 1991). It received 1 iquid wastes isolated from tubes containing ruptured fuel elements in the 105-DR Reactor and may also have been used for the disposal of excess "INK" (1iquid boron solution) used in the $3 X$ safety system (Clukey 1956). 
The 10- by $10-$ by $10-f t$-deep pluto crib was a gravel-filled wooden structure made of railroad ties. However, during sampling by Dorian and Richards (for the UNI-946 document [1975 to 1976]), the samples appeared to have no
gravel (WHC 1991). The 116-DR-4 crib received 4,000 $L$ of 1 iquid wastes that include the
following radionuclide inventory:

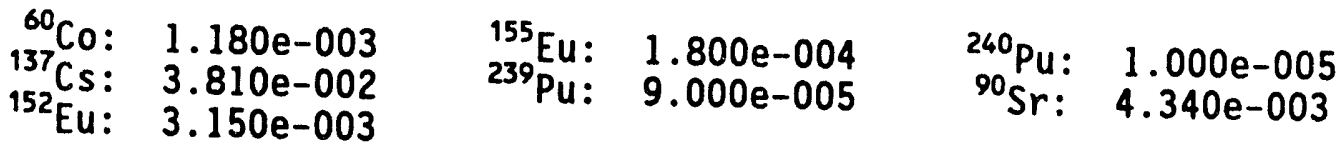

\section{(Stenner et al 1988)} Additionally, the $116-D R-4$ hazardous chemical inventory includes $0.004 \mathrm{~kg}$
of sodium dichromate.

Dorian and Richards (1978) reports the results of soil samples taken from three locations. It reports the crib volume as $2.3 \times 10^{4} \mathrm{ft}^{3}$ and mass as 1.6 $X 10^{\circ} \mathrm{g}$. The full tables are provided in Appendix $C$ and are summarized in data provided above. Compare the "Curies" column to the Stenner et al (1988)

Table 5-4. 116-DR-4 Radionuclide Inventory.

\begin{tabular}{|c|c|c|}
\hline RADIONUCLIDE & AVE. $\mathrm{pCi} / \mathrm{g}$ & CURIES \\
\hline${ }^{238} \mathrm{Pu}$ & & 0.00 \\
\hline${ }^{239 / 240} \mathrm{Pu}$ & $6.30 \mathrm{E}^{-02}$ & $1.00 \mathrm{E}^{-04}$ \\
\hline${ }^{90} \mathrm{Sr}$ & $3.30 \mathrm{E}^{+00}$ & $5.30 \mathrm{E}^{-03}$ \\
\hline${ }^{3} \mathrm{H}$ & & 0.00 \\
\hline${ }^{152} \mathrm{Eu}$ & $3.00 \mathrm{E}^{+00}$ & $4.80 \mathrm{E}^{-03}$ \\
\hline${ }^{60} \mathrm{Co}$ & $2.20 \mathrm{E}^{+00}$ & $3.50 \mathrm{E}^{-03}$ \\
\hline${ }^{154} \mathrm{Eu}$ & & 0.00 \\
\hline${ }^{134} \mathrm{Cs}$ & $1.60 \mathrm{E}^{-02}$ & $2.60 \mathrm{E}^{-05}$ \\
\hline${ }^{137} \mathrm{Cs}$ & $2.90 \mathrm{E}^{+01}$ & $4.60 \mathrm{E}^{-02}$ \\
\hline${ }^{155} \mathrm{Eu}$ & $3.60 \mathrm{E}^{-01}$ & $5.80 \mathrm{E}^{-04}$ \\
\hline TOTAL CURIES & & $6.00 \mathrm{E}^{-02}$ \\
\hline \multicolumn{2}{|c|}{ (Dorian and Richards 1978} & \\
\hline
\end{tabular}


WHC-SD-EN-TI-181, Rev. 0

Table 5-5. 116-DR-4 Radionuclide Inventory.

\begin{tabular}{|c|c|}
\hline RADIONUCLIDE & AVE. $\mathrm{pCi} / \mathrm{g}$ \\
\hline $\begin{array}{l}\text { Ave. } \\
\text { Beta/Gamma }\end{array}$ & $3.80 \mathrm{E}^{+01}$ \\
\hline $\begin{array}{l}\text { Max. } \\
\text { Beta/Gamma }\end{array}$ & $7.00 \mathrm{E}^{+01}$ \\
\hline $\begin{array}{l}\text { Ave } \\
239 / 240 \mathrm{Pu}\end{array}$ & $6.30 \mathrm{E}^{-00}$ \\
\hline $\begin{array}{c}\text { Max } \\
239 / 240 \mathrm{Pu}\end{array}$ & $1.90 \mathrm{E}^{-01}$ \\
\hline
\end{tabular}

(Dorian and Richards 1978)

The appearance today is that of a vegetation-free, cobble-covered field. There is a square concrete marker identifying the pluto crib site. It is physically located just inside the exclusion area fence in the southeast corner near the 100-DR Reactor (Figure 5-4).

The 116-DR-4 pluto crib is a registered underground injection well (DOE $19,38)$ and has an HRS Migration score of 9.13 (Stenner et al 1988).

Figure 5-4. 105-DR Pluto Crib.

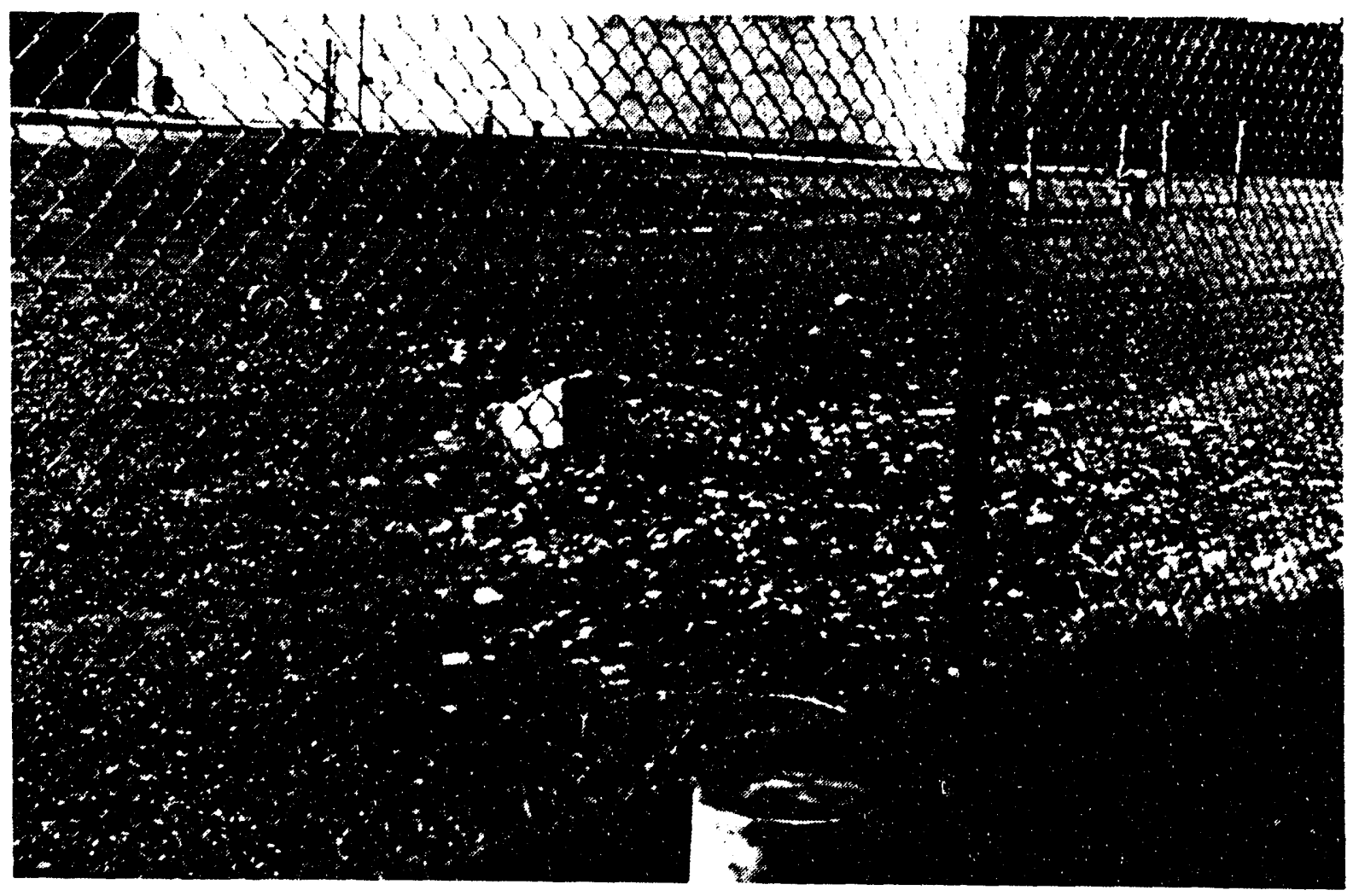




\subsection{6-DR-6 (1608-DR LIQUID DISPOSAL TRENCH)}

The 116-DR-6 is an inactive 1iquid waste site that operated from 1953 to 1965. It was located at Hanford coordinates $\mathrm{N} 91300 \mathrm{~W} 52550$ and received coolant that was diverted to the trench during the Ball $3 X$ upgrade. It also received diverted water when maintenance was necessary on the effluent system.

Site employees report that this trench also received decontamination effluents (dilute citric and nitric acid, water, and solvents) from the decontamination pad in the fuel storage area. They also report that on very hot days a solvent odor was noticeable at the location.

The 50- by 10- by 10-ft-deep trench received in excess of an estimated $7,000,000$ L of waste effluents. The hazardous chemical inventory included 2.0 $\mathrm{kg}$ of sodicm dichromate. The trench was covered with about $6 \mathrm{ft}$ of clean soil upon closure (WHC 1991).

The trench has been described as a crib (subsurface trench) that would sometimes receive effluent volumes that were great enough to cause seepage to the surface and would, subsequently, drain across the surface to the east of the crib. This idea appears to be confirmed by the absence of an open trench in aerial photographs taken when the trench was active. Soil was added on at least two occasions to bring the surface to grade and eliminate subsidence of
the area.

No radionuclide inventory information is available.

The site appears today as a vegetation-free, cobble-covered field. There are no other markings or identifying features. It is included in a much larger area that is surrounded by permanent concrete markers and posted with Underground Radioactive Material warning signs. Just to the north of the trench location, the exclusion area fence has been modified (Figure 5-5).

This waste site has an HRS Migration score of 42.32 (Stenner et al 1988).

\subsection{6-DR-7 (105-DR INKWELL CRIB)}

The 116-DR-7 is an inactive liquid waste site that operated during 1953. The crib is located at Hanford coordinates N91123 W52734 and is currentiy identifiable by a concrete marker. It was used to receive the liquid potassi$3 X$ system upgrade.

The 5 - by 5 - by 10-ft-deep crib received a hazardous chemical inventory of $4,000 \mathrm{~L}$ of potassium borate (Stenner et al 1988) and is a registered underground injection well (DOE 1988). Cramer (1987) reports that $3,000 \mathrm{~kg}$ of potassium borate were disposed of at this site. 
Figure 5-5. 1608-DR Effluent Trench.

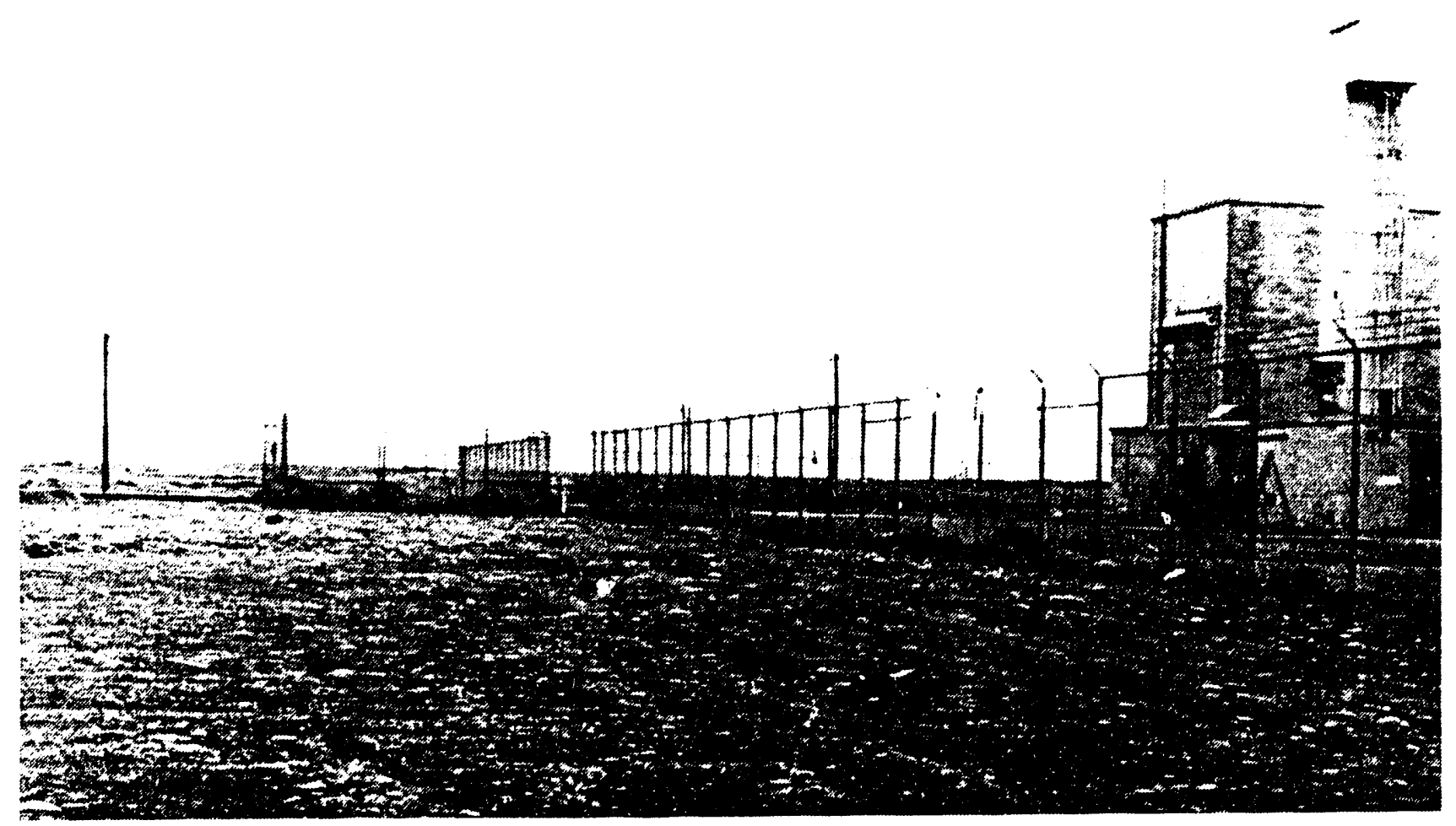

In addition, the radionuclide inventory in curies decayed through April 1 , 1986 includes $1.000 \mathrm{E}^{-001} \mathrm{Ci}$ Beta and $1.000 \mathrm{E}^{-003} \mathrm{Ci}$ Gamma (Stenner et al 1988).

The crib is also described as a tank of unknown size that is buried under about $6 \mathrm{ft}$ of soil (Tatum 1967 and Hanford Drawing H-1-4046).

The site appears today as a vegetation-free, gravel-covered area. It is marked by a single square concrete marker that has been knocked over. The site is adjacent to a concrete pad that once supported a storage building (Figure 5-6).

This waste site has an HRS Migration score of 28.96 (stenner et al 1988).

\subsection{6-DR-8 (117-DR SEAL PIT CRIB)}

The 116-DR-8 is an inactive liquid waste site that operated from 1960 to 1964 in support of reactor operations and until 1986 in support of the 105-DR Sodium Fire Facility. The crib is located at Hanford coordinates $N 90716$ W52610 (Hanford Drawing H-1-19823), which is about $250 \mathrm{ft}$ south of the DR exclusion area fence and directly east of the 118-DR-1 burial ground. The area is marked by steel fence posts and has a large steel vent extending above the ground surface at the approximate center of the area. 
Figure 5-6. 105-DR Ink Well Crib (Tank).

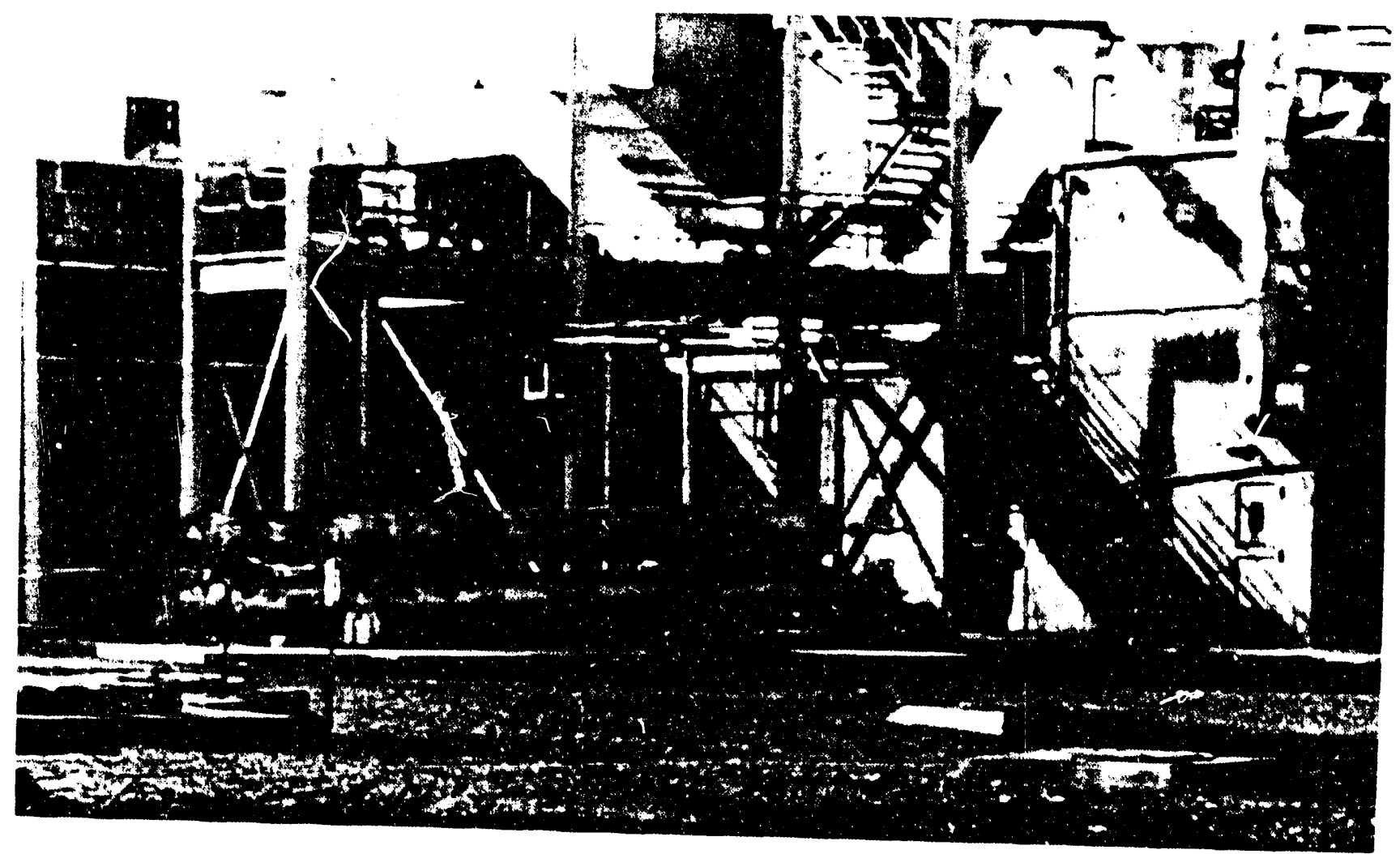

The $10-$ by- 10 by $10-f t$-deep crib received an estimated $240,000 \mathrm{~L}$ of 1 iquid wastes from the containment system, 117-DR Building, and seal pits (WHC 1991). Construction details can be seen on Hanford Drawing H-1-15261, which crib.

Dorian and Richards (1978) report that the radionuclide inyentory for this waste site includes the following: Ave. Beta-Gamma $<1.70 \mathrm{E}^{-01}\left({ }^{3} \mathrm{H},{ }^{14} \mathrm{C}\right) \mathrm{pCi} / \mathrm{g}$ with a total curie content of $1 \mathrm{mCi}$ Stenner et al $(1988)$ reports the
radionuclide inventory as $1.000 \mathrm{E}^{-003} \mathrm{Ci}$ Beta and $1.000 \mathrm{E}^{-003} \mathrm{Ci}$ Gamma.

The site appears today as an open field, covered with grasses and other natural vegetation, surrounded by red steel posts. There are no other
postings at the site (Figure 5-7).

The 116-DR-8 is a registered underground injection well (DOE 1988) and has an HRS Migration score of 0.00 (Steriner et al, 1988).

\subsection{8-D-5 (BALL 3X BURIAL GROUND)}

The 118-D-5 is an inactive solid waste site that operated during 1954. It is located at Hanford coordinates $N 90900$ W52750, which is about $100 \mathrm{ft}$ south of the 105-DR Building and outside the exclusion area fence (WHC 1991). It 1954 (Stenner et al 1988). This sithe Ball $3 X$ work in burial ground number 3 (Heid 1956). 
Figure 5-7. 117-DR Crib (116-DR-8).

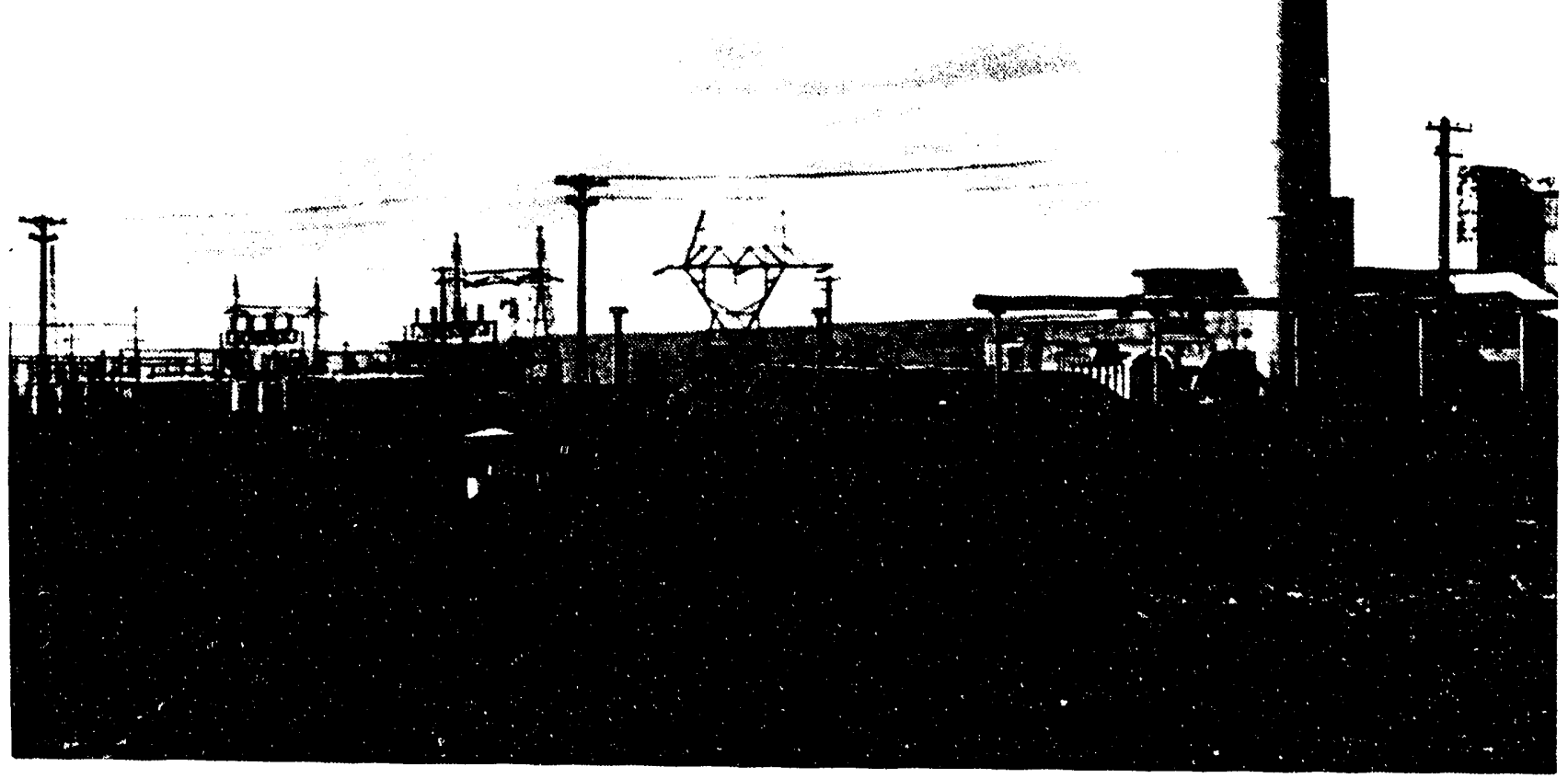

The site consists of two parallel burial trenches, one on each side of the above-ground experimental level one discharge pipe. Each trench is 40 by 20 by $10 \mathrm{ft}$ deep (WHC 1991). There is disagreement about the exact location and size of these trenches: Stenner et al (1988) reports that the 118-DR-5 is a 20- by 20- by 10-ft-deep single trench, Hanford Drawing H-1-4046 (sites 4 and 17) shows two trenches located east of the experimental level one discharge pipe, and Hanford Drawing H-1-19823 indicates that the west trench is directly beneath the experimental discharge pipe.

The radionuclide content in curies decayed through April 1, 1986 of the 10 $\mathrm{m}^{3}$ of waste disposed of is ${ }^{60} \mathrm{CO} 1.000 \mathrm{E}^{+00}$.

The site appears today as a vegetation-free, cobble-covered area with uneven terrain. A concrete box with a steel lid, part of the septic drain system for the 105-DR facilities, is located within the area. Support structures for the level one experimental discharge pipe also remain in place at each end of the site. The level one experimental discharge pipe, north of the access road near the site, remains intact to the 105-DR Reactor Building (Figure 5-8).

This waste site has an HRS Migration score of 1.84 (Stenner et al 1988). 
Figure 5-8. VSR Thimble Burial Ground South of 105-DR.

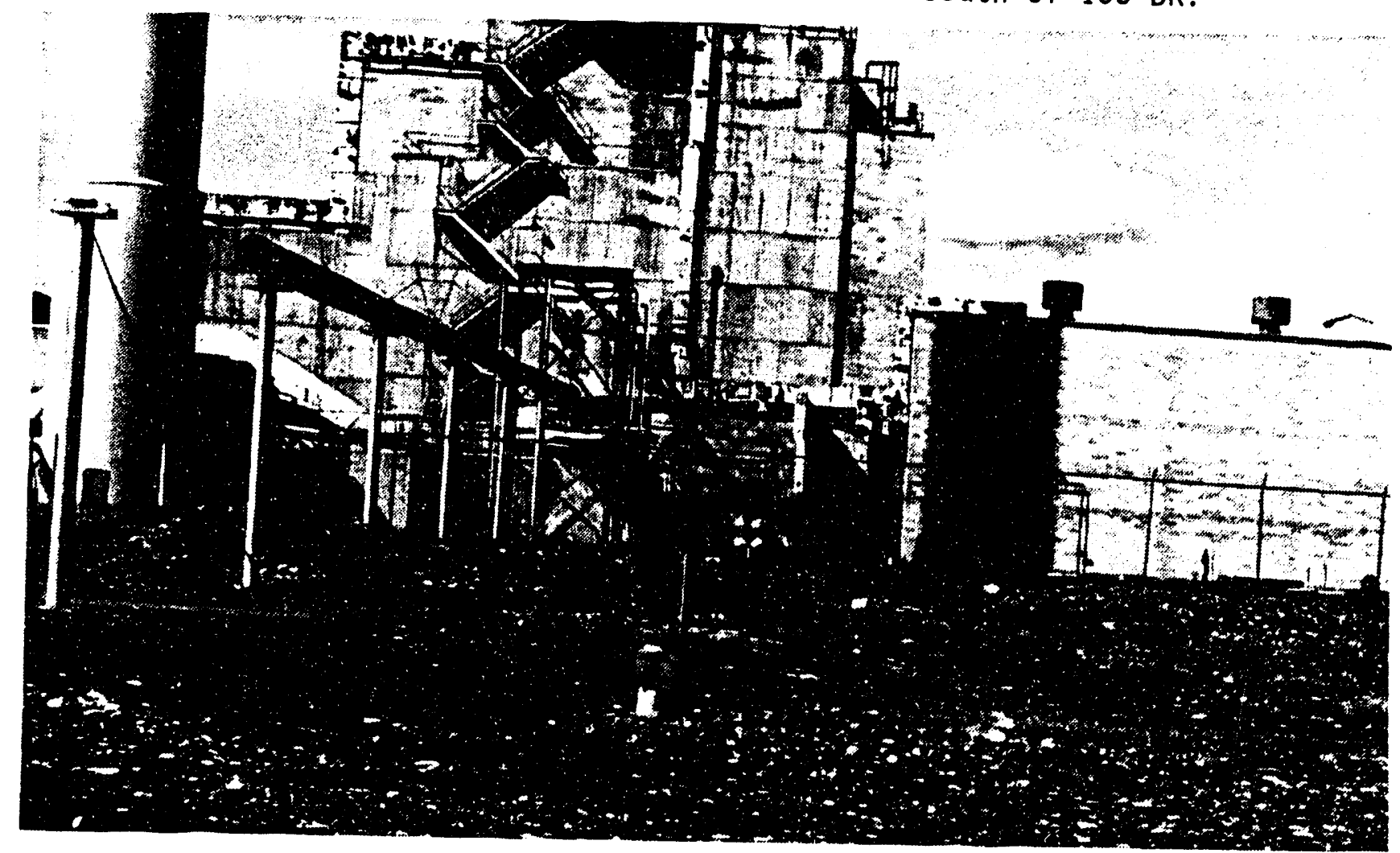

\subsection{8-DR-2 (105-DR REACTOR BUILDING)}

The 118-DR-2 is an inactive solid waste site that operated from october 3 , 1950 to December 30,1964 . The reactor is located at Hanford coordinates N91240 W52790, which is at the south end of the 100-D/DR exclusion area, "5/8 miles from the Columbia River shoreline at mile point $378^{n}$ (PNL 1991).

The reactor building consists of the following:

- The reactor block, which includes the graphite moderator stack, biological and thermal shields, pressure tubes, and the safety and
control systems

- The irradiated fuel storage basin and decontamination wash pad

- Contaminated work and equipment rooms and areas of the reactor building (WHC 1991)

- Non-contaminated control, equipment, and personnel facilities.

The facility contains an estimated $13,500 \mathrm{Ci}$ of radionuclides, 94 tons of lead, $100 \mathrm{ft}^{3}$ of asbestos (WHC 1991) and 500 pounds of cadmium (WHC 1991). It
is aiso known as the 105-DR. 
Upon deactivation, floor smears were taken at several locations in the building. The reactor had been down for two weeks. The radioactivity of these smears was periodically measured with a scintillation counter over the next four months to determine the decay rate that might be expected for the various locations. It was found that the predominant isotope contamination was of the long half life variety. Readings were also taken on front and rear nozzles that had been removed from the reactor during the final April outage. The cpm readings were taken with a portable CP instrument and the data shown in Table 5-6 was found.

Table 5-6. Survey Results.

\begin{tabular}{|c|c|c|c|c|c|c|}
\hline DATE & $\begin{array}{l}\text { FRONT } \\
\text { Inside } \\
\end{array}$ & $\begin{array}{l}-c / m \\
\text { Outside }\end{array}$ & $\begin{array}{c}\text { REAR } \\
\text { Inside } \\
\end{array}$ & $\begin{array}{l}c / m \\
\text { Outside }\end{array}$ & $\begin{array}{r}\text { REAR } 0 \\
\mathrm{~m}-\mathrm{rad} / \mathrm{hr} \\
\end{array}$ & $\begin{array}{l}\text { SIDE } \\
\mathrm{mr} / \mathrm{hr}\end{array}$ \\
\hline $4-21-64$ & 800 & 8,000 & 18,000 & 18,000 & 125 & 10 \\
\hline $4-29-64$ & 700 & 7,000 & 16,000 & 14,000 & -- & -- \\
\hline $5-05-64 *$ & 800 & 9,500 & 16,000 & 15,000 & 80 & 8 \\
\hline $5-12-64$ & 400 & 7,000 & 9,000 & 8,000 & 75 & 7 \\
\hline $6-08-64$ & -- & 5,000 & 7,000 & 7,000 & 50 & 5 \\
\hline $7-09-64$ & -- & 5,000 & 7,000 & 7,000 & 40 & 5 \\
\hline
\end{tabular}

* no reason was given for the increase from the previous months readings.

(Copeland 1964)

A systematic scheme of effort and direction was used to decontaminate radiation zones during deactivation of the reactor and associated facilities. Initial efforts consisted of clearing the open areas of equipment, tools and materials not intended for storage in the building. This was followed by general housekeeping and radiation surveys of each zone.

"The general flow of the decontamination work was from top to bottom and far to near sides. Approximately 68 locations were surveyed for beta-gamma contamination. Of these, 43 were previously established radiation zones of which 25 required decontamination with detergent solutions and/or chemical decontamination to satisfy the post-deactivation requirements. Two zones, the air supply tunnel to the discharge area and the charge platform pit, required special attention to alleviate the hazard of contamination spread.

"A11 known radioactive sources used for instrument calibration or source response checks were removed except for a ${ }^{137} \mathrm{Cs}$ source in the near side sample room gamma monitor system. This source was left in the monitoring device and tagged with radiological information. The wash pad, transfer area and storage area were not included in deactivation activities and were to be maintained by 105-D personnel" (Winship 1965).

The irradiated fuel storage basin leaked for a number of years prior to deactivation. The leak rate was small, and the location of the leak was never identified (WHC 1991) although one site of basin leakage, outside door number 14, was isolated at the rear of the building and can be seen in two photographs taken in May 1957. It is assumed that this leak was repaired (Figure 5-9). 
Figure 5-9. 105-DR Fuel Storage Basin Leakage.

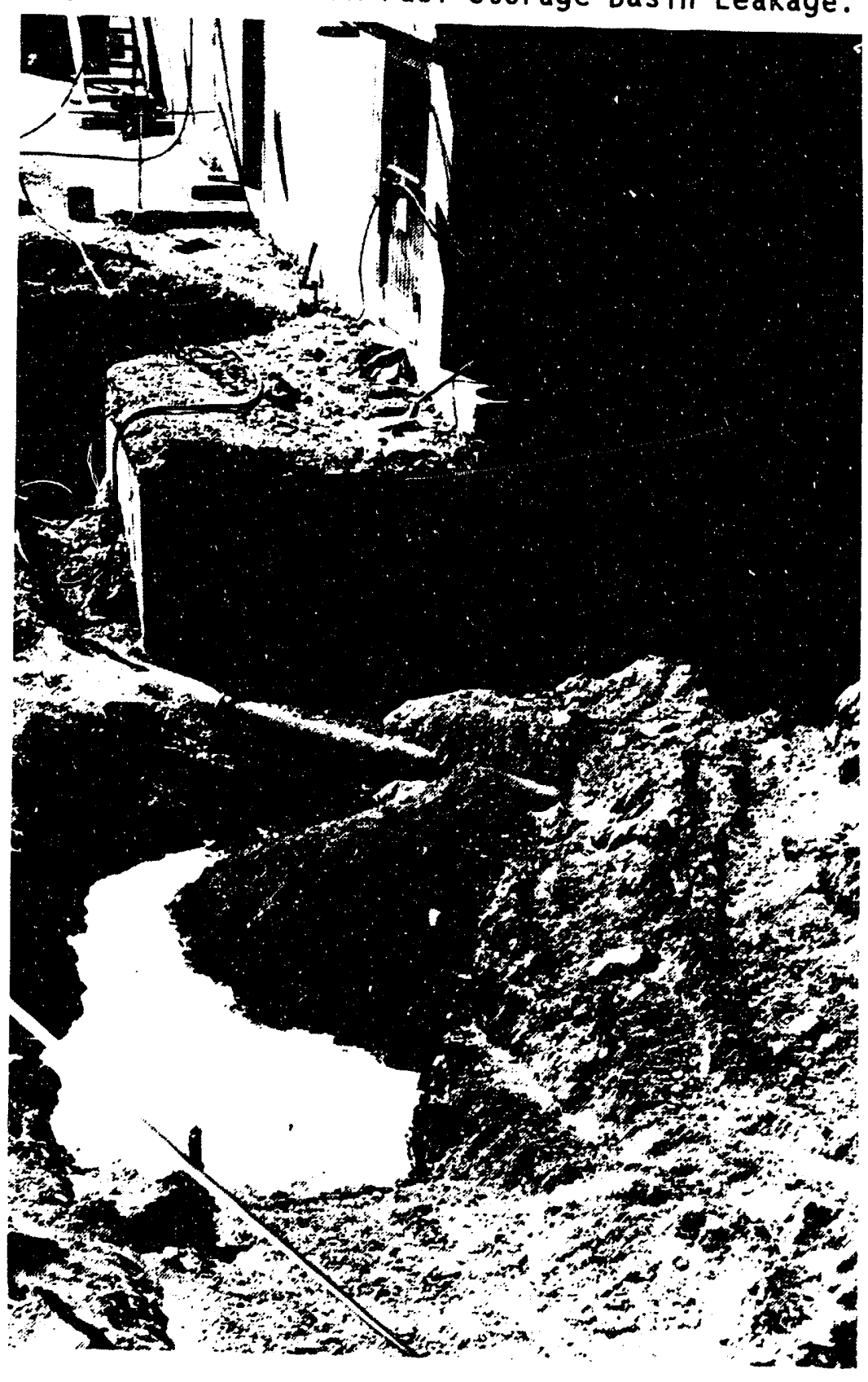

Three exhaust fans, inlet valves, piping, and some of the switch gear and transformers have been removed. The Boron Ball $3 x$ balls remain in place an asphalt emulsion (ATCO Asphalt storage basins were cleaned out and coated with other contaminated equipment and 1840 , tradename expired). The sludge and disposed of in the 200 West Area burial grounds.

In 1985, the accessible "clean" and contaminated asbestos was removed from all areas of the 105-DR Facility except the HEDL Sodium Fire Facility (122-DR-
1) and was buried in approved burial grounds. 
The reactor appears much the same today as it did during operations (Figure 5-10). This waste site has not been assigned an HRS Migration score.

Figure 5-10. 105-DR.

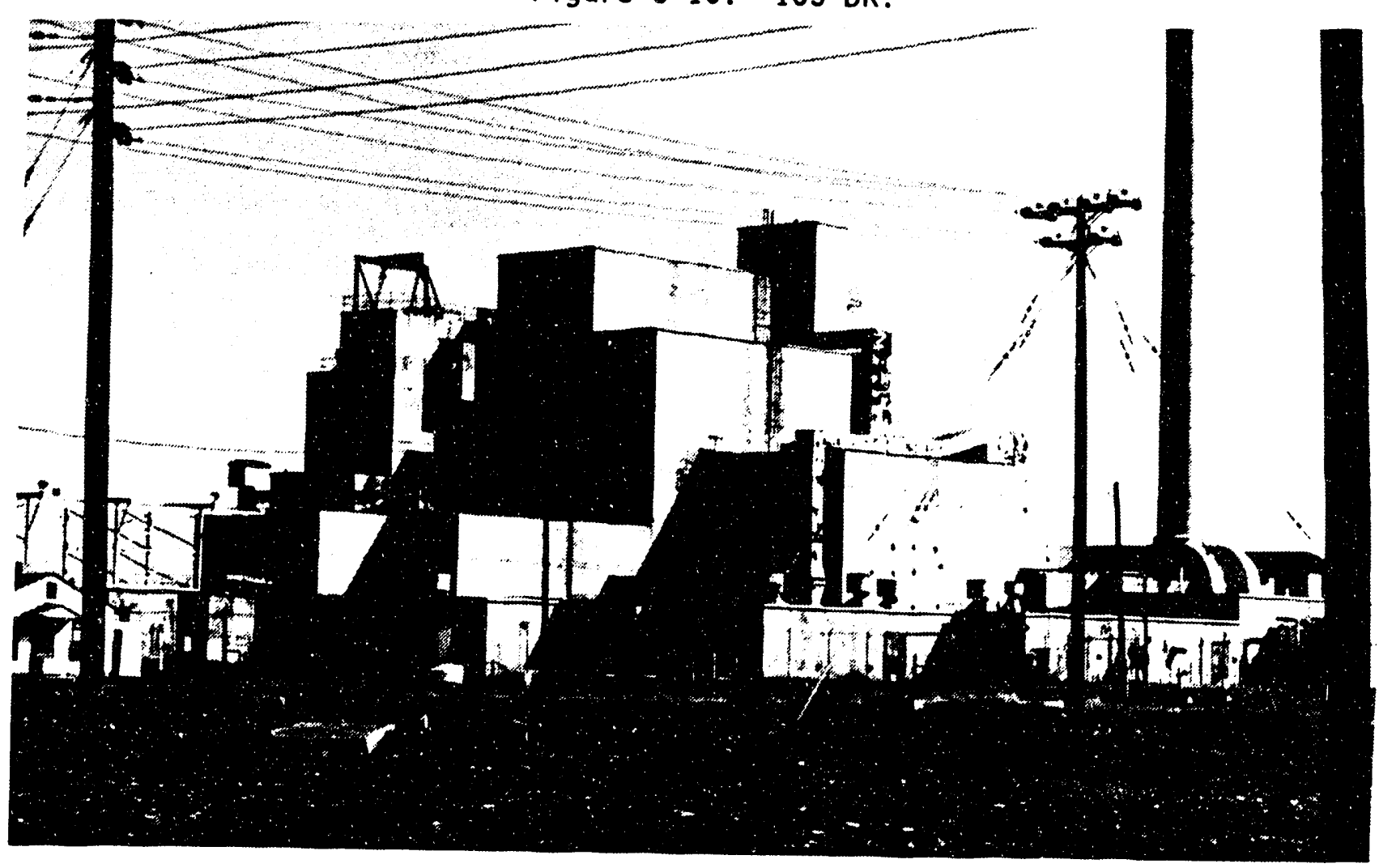

\subsection{2-DR-1 (105-DR SODIUM FIRE FACILITY)} The 122-DR-1 is an inactive liquid waste site that operated from 1972 to
1986 . The facility is located at Hanford coordinates N91240 W52950, which is
in the supply and exhaust fan wing in the supply and exhaust fan wing of the 105-DR Reactor Building (WHC 1991) Building and portions of the 116-DR Reactor exhaust stack, the 117-DR Filter Sampling Builsing (Gano crib (116-DR-8) and the 119-DR Reactor Exhaust Stack treatment of sodium and and $\mathrm{Hall} 1987$ ). It was used for the testing and treatment of sodium and other alkali metals by thermal treatment.

Wastes consisted of sodium, lithium, and sodium-potassium alloy. Approximately $20,000 \mathrm{~kg}$ were managed each year. The facility may be used to store up to $20,000 \mathrm{~L}$ of dangerous wastes (DOE 1988). It was al so known as the 105-DR

Site personnel estimated that the total volume of sodium and other alkali metals used at the facility for burn tests was about $20,000 \mathrm{Kg}$. Little treatment, as such, was done and nearly all alkali metal materials were used to conduct material and reaction tests. Some small amounts of sodium metal and oxide wastes were disposed of by thermal treatment at the facility. 
The total volume of wastes treated is estimated to be less than 2,000 1bs. Site personnel stated that, to their knowledge, the volume of materials used and wastes treated never approached the volumes stated in The Registration of Hanford Site Class V Underground Injection Wells (DOE 1988). They believed that the high figures were based on figures given for permit application purposes.

Figure 5-11. French Drain Near the Sodium Fire Facility Water Filter.

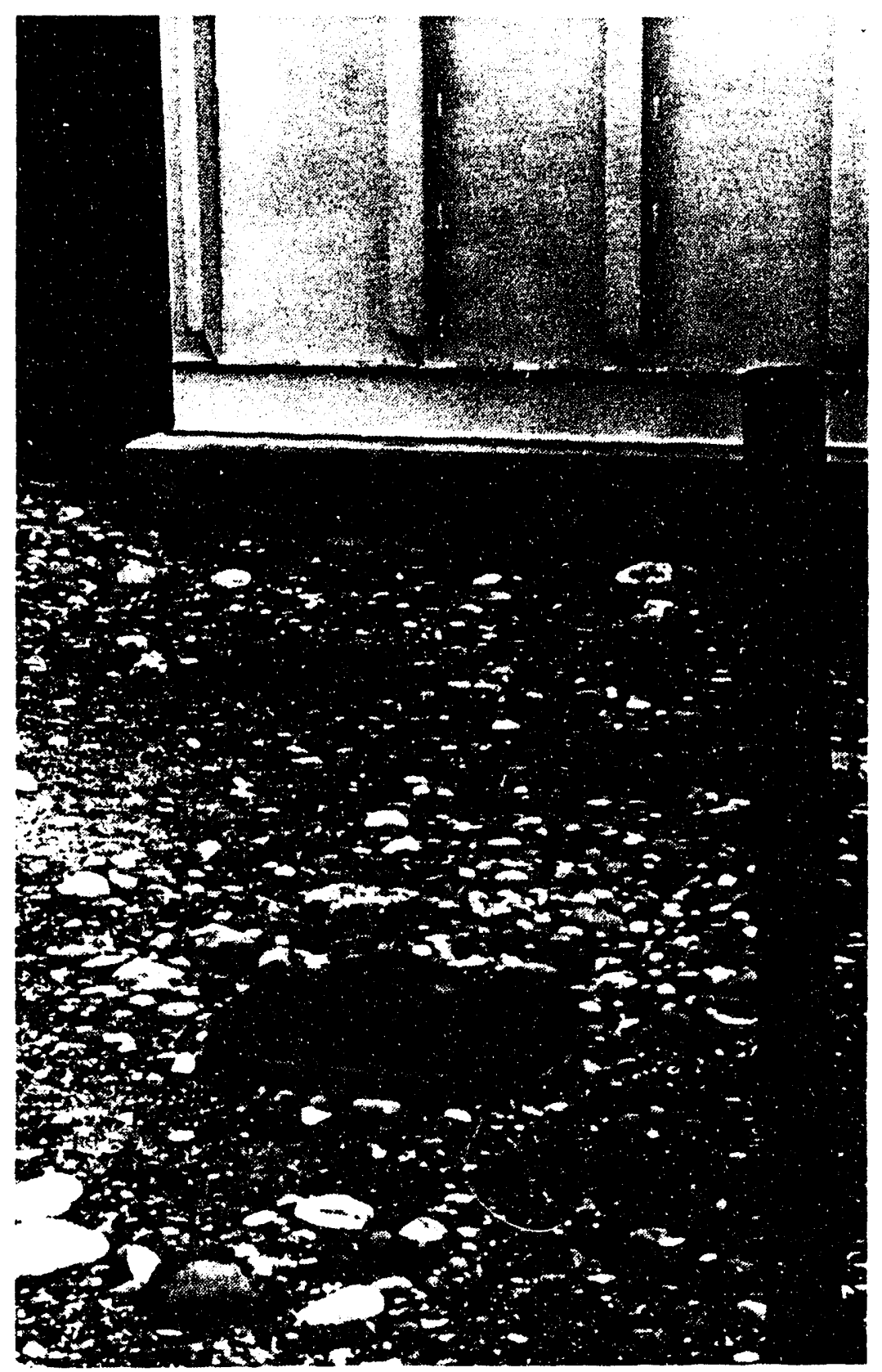

Thermal treatment consisted of heating the waste to the point of oxidation. Typical containers were 55gal drums stored and treated inside a concrete building. Nonhazardous aqueous hydroxide wastes consisting of sodium hydroxide, carbonate, and water were discharged to the 116-DR-8 crib (WHC 1991).

A field survey of the facilities on March 17, 1992 revealed a small french drain, made of 12in. concrete pipe, located just west of the water scrubber building. This drain, which is covered by a steel lid, has a 2 -in. inlet pipe that enters the drain on the east side about $2 \mathrm{ft}$ below grade. The drain is protected from traffic by three yellow steel posts. The purpose of the drain is unknown (Figure 5-11).

Just to the north of the water scrubber facility is a metal storage building that houses a 6,000 -gal stainless steel tank filled with 39,000 lbs of new, unused sodium meta?. 
Post deactivation surveys of the 117-DR Filter Building were performed in 1964. Smear surveys of all three levels indicated less than $200 \mathrm{c} / \mathrm{m}$ and 1 ess than $3 \mathrm{mrem} / \mathrm{hr}$ at one foot from all surfaces. Maximum indication at the cell hatches was $2,000 \mathrm{c} / \mathrm{m}$ direct check using a GM counter. Post deactivation (1964) surveys conducted in the 119-DR Sampling Building resulted in the following data: all smears indicated less than $200 \mathrm{c} / \mathrm{m}$ and dose rates of less than $3 \mathrm{mrem} / \mathrm{hr}$ at one foot from all surfaces (Winship 1965).

Only one side of the 117-DR Facility was used for the Sodium Fire Facility. The filter banks on the north side were changed out prior to use by the Sodium Fire Facility and were transported to the 200 West Area burial grounds fer disposal.

The facility as it appears today can be see in Figure 5-12. This waste site has not been assigned an HRS Migration score.

Figure 5-12. Sodium Fire Facilities.

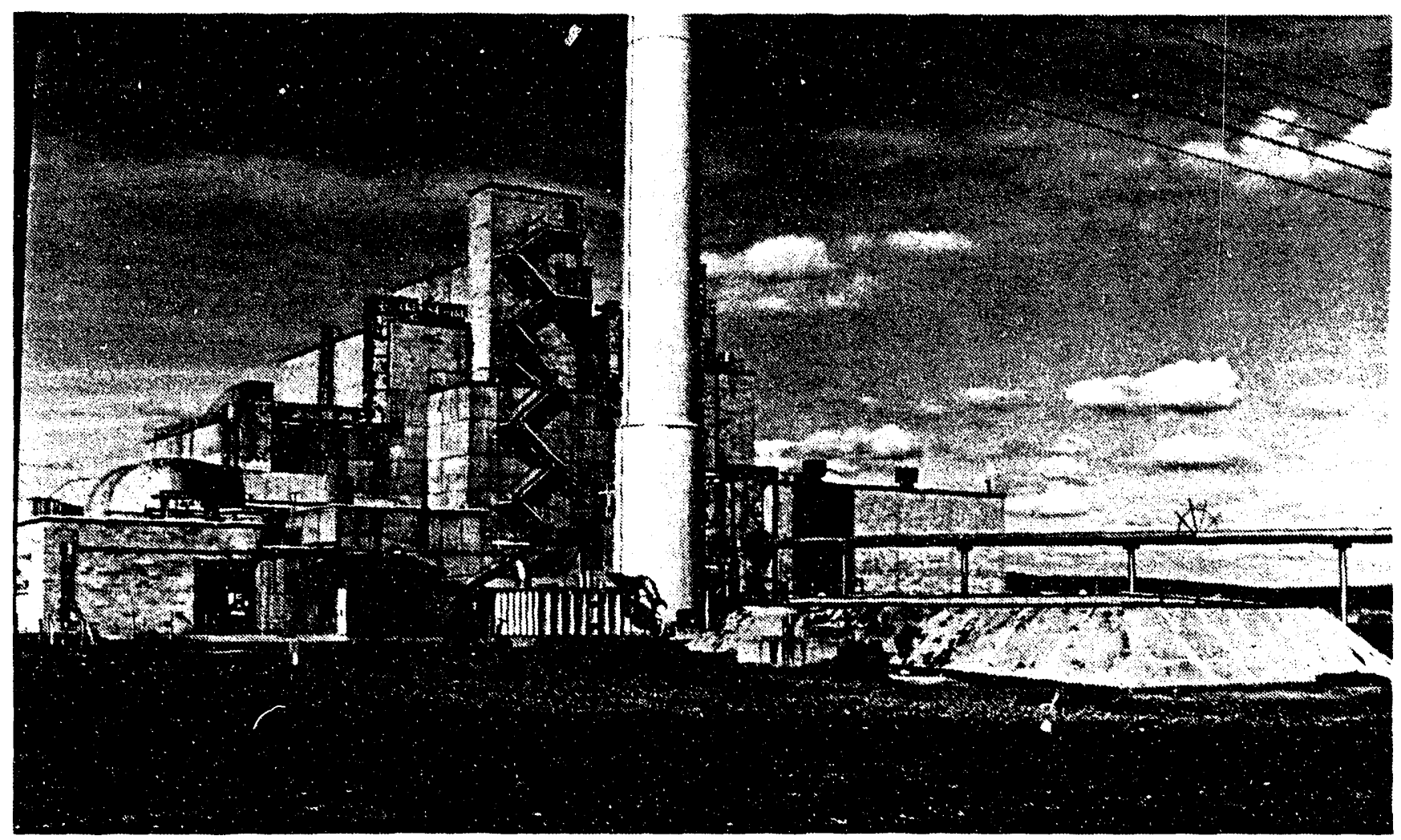

\subsection{6-DR-1 (190-DR CLEARWELL TANK PIT)}

The 126-DR-1 is an active solid waste site that began operation as a burial ground in the 1970's. The site is located at Hanford coordinates N90875 W53900, which is directly east of the 183-DR Water Treatment Facility site (demolished) and about 1,200 ft southwest of the 105-DR Reactor Building. 
It is an excavated area between the 183-DR and 190-DR that once contained four 3,750,000-gal steel water storage tanks. The tanks were removed by a salvage contractor. Approximately $25 \%$ of the bottom surface area (the northwest sector of the pit) contains a layer of waste about 5 to $10 \mathrm{ft}$ deep that is covered with pit run backfill. Demolition and inert waste from demolished facilities, including rubble from portions of the 115-D/DR and some rubble from 183-DR, were placed in this area. In 1989, small amounts of friable asbestos were found scattered throughout the southern sector and now it is posted as an asbestos area. The asbestos is believed to be pipe lagging remnants that resulted from salvage operations during the 1970's (Figures 5-13 and $5-14)$.

Figure 5-13. 190-DR Tankwell Pit Burial Ground.

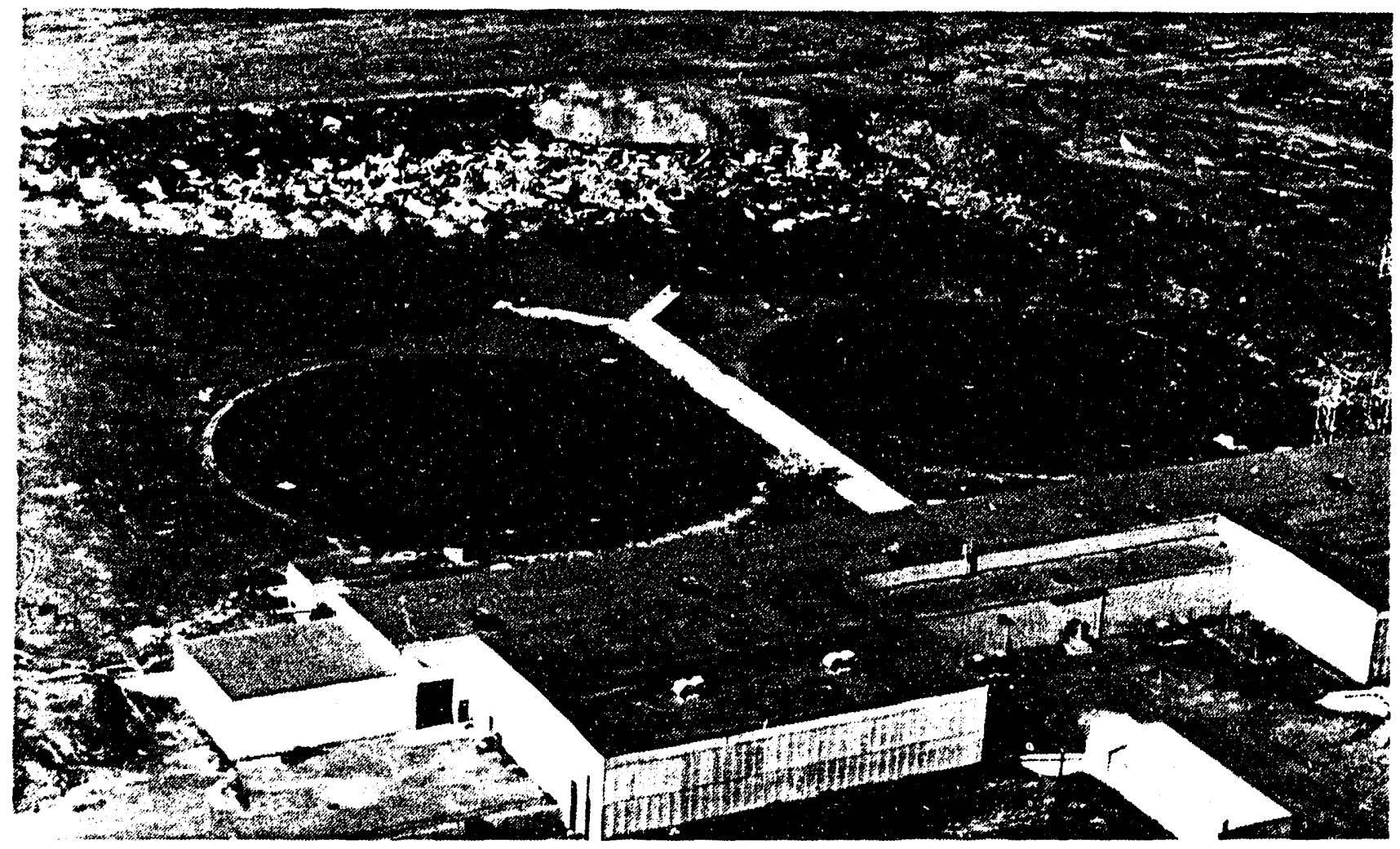

The 126-DR-1 site may contain chromates in both the soil and underground piping as a result of its association with water treatment. Because of this potential, it is closed to further waste disposal (WHC 1991).

Because absolute control of the burial ground was not maintained during its operation, uncontrolled dumping reportedly occurred. There is potential for chemical and radioactive contamination similar to that found in the 184-D coal pit (126-D-2) described in section 4.19, al though the volume of these contaminants is expected to be much less than those found in 184-D.

This waste site has not been assigned an HRS Migration score. 
Figure 5-14. Asbestos Contamination Area in the 190-DR Tankwell Pit Burial Ground.

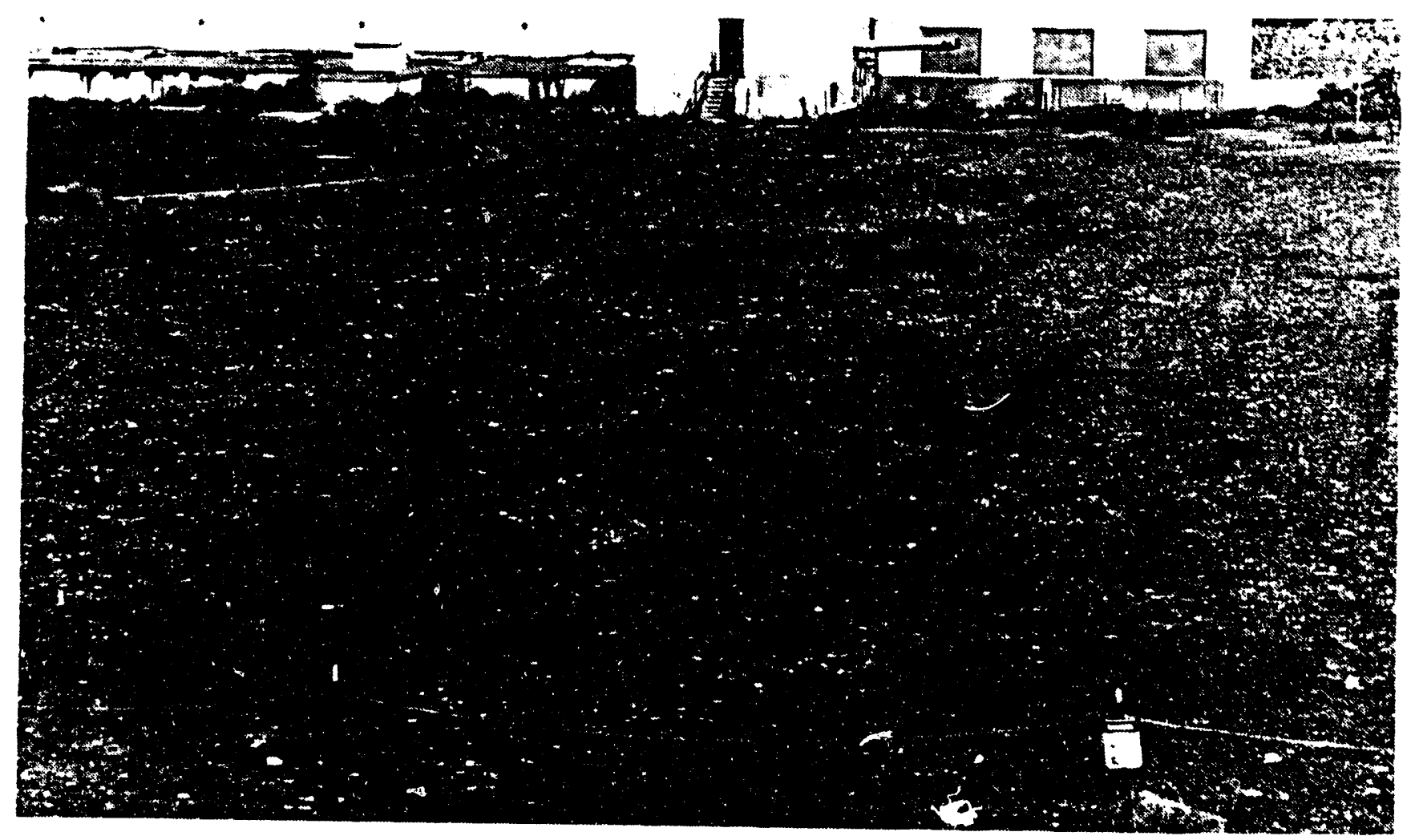

\subsection{2-DR-1 (1608-DR WASTE KATER PUMPING STATION SITE)}

The 132-DR-1 site, also known as the 1608-DR effluent pumping station, is an inactive liquid waste site that operated from 1950 to 1964 and was demolished in 1987. It is located at Hanford coordinates N91364 W52648 (northeast corner), which is adjacent to the northeast corner of the 105-DR Reactor Building within the 105-D/DR Exclusion Area Fence. The facility received water from reactor building drains containing trace amounts of low-level radionuclides and decontamination chemicals. Radionuclides were primarily miscellaneous fission and activation products. The decontamination chemicals consisted of sodium fluoride, oxalic acid, and citric acid.

The 132-DR-1 Facility consisted of the following:

- An above-ground structure consisting of concrete block walls, a reinforced concrete floor, and a rooftop reinforced concrete deck with a composition surface

- A below-grade structure of reinforced concrete

- An operating level which consisted of pumping equipment

- An accumulation inlet chamber which fed three discharge sump chambers. The accumulation chamber was located in the northern section of the facility. 
Post deactivation surveys (1964) indicated contamination levels of up to $500 \mathrm{c} / \mathrm{m}$ in one area. No attempt was made to decontaminate the facility other than general housekeeping. All other areas of the facility were surface smearable at less than $? 00 \mathrm{c} / \mathrm{m}$ and less than $3 \mathrm{mrem} / \mathrm{hr}$ at one foot from contact (Winship 1965).

Decommissioning consisted of the following steps:

1) Renioval of about $136 \mathrm{ft}^{3}$ of asbestos

2) Removal/disposal of pump equipment and related piping

3) Removal/disposal of about $126,750 \mathrm{gal}$ of sump water

4) Removal/disposal of fifteen 55-gal drums of sludge from the sumps

5) Demolition and site grading.

All decomnissioning activities were completed on September 30, 1987 (WHC 1991). The residual sump water removed during decommissioning was disposed of in the 1325-N Liquid Waste Disposal Facility, all solid wastes, including sludge, were packaged and shipped to the 200 West burial grounds for disposal.

The site appears today as a vegetation-free, graveled area and looks much like a gravel parking lot (Figure 5-15). It has not been assigned an HRS
Migration score.

Figure 5-15. 1608-DR Facility Site.

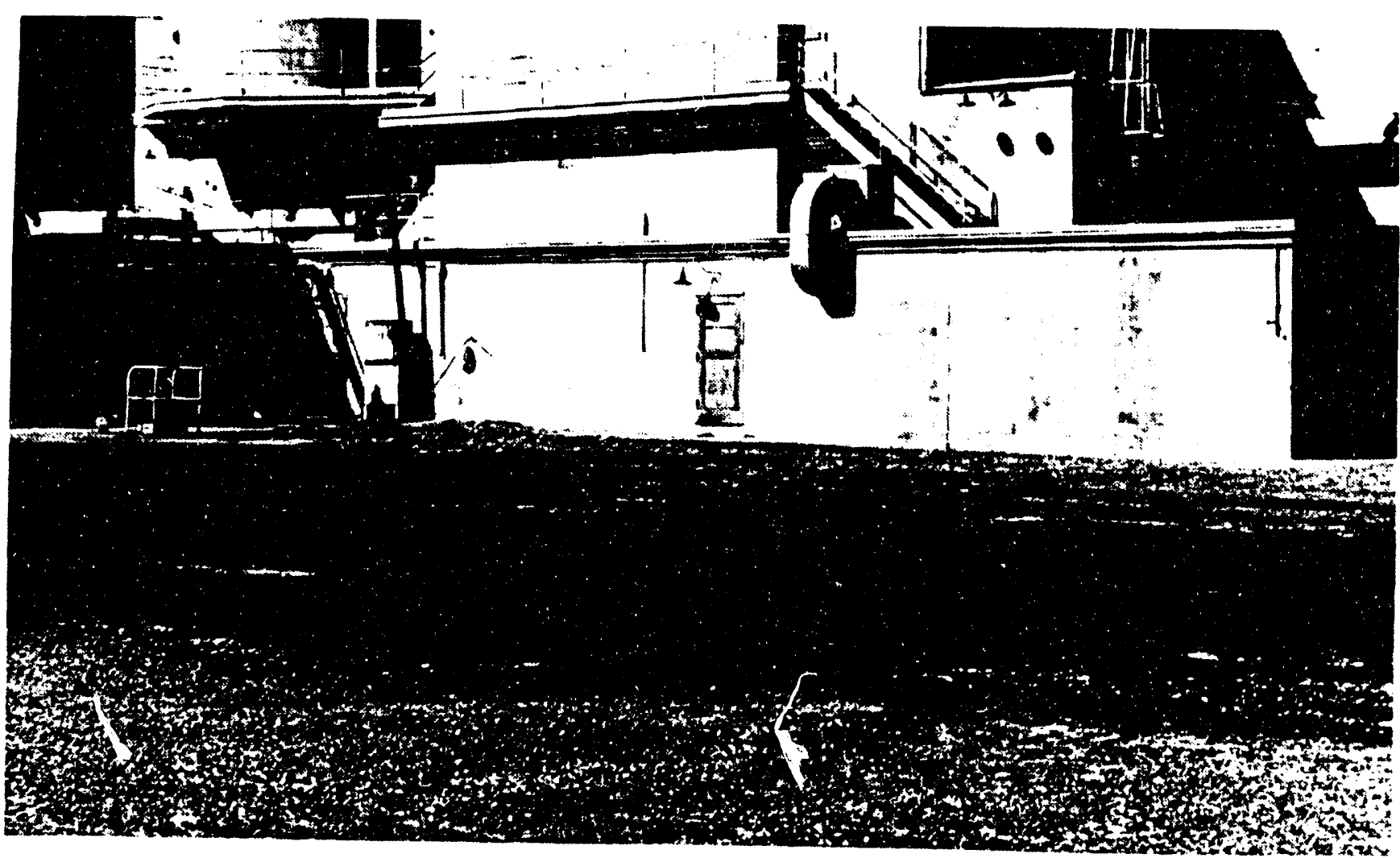


WHC-SD-EN-TI-181, Rev. 0

\subsection{2-DR-2 (116-DR REACTOR EXHAUST STACK)}

The 132-DR-2 is an inactive solid waste site that operated from 1950 to 1986. The stack is located at Hanford coordinates N91085 W52810 (Hanford Drawing M-1901-5), which is on the south side of 105-DR. It was used to exhaust air from the 105-DR Reactor work areas and later from the 105-DR Sodium Fire Facility.

The stack is a monolithic, reinforced concrete structure with a maximum wal1 thickness of $1.5 \mathrm{ft}$ at the base. It rests on a double octagon-shaped base that extends $17.5 \mathrm{ft}$ below grade. An opening at the base provides access to its interior portion. This opening is fitted with a steel door.

Originally, 105-DR exhaust air flowed directly from the reactor building to the exhaust stack. Following completion of the confinement project in 1960, the exhaust air was diverted to the 117-DR filter building, via underground ducts, prior to release through the stack. Beginning in 1972, the stack was used to support operations relating to the 105-DR Sodium Burn Facility (122-DR-1). The interior of the stack contains an unknown quantity of low-level radioactive materials.

The stack remains standing and is operable (WHC 1991).

This waste site has not been assigned an HRS Migration score.

\subsection{7-D SEPTIC TANKS AND ASSOCIATED DRAIN FIELDS}

One septic tank system is located in the 100-DR-2 Operable Unit. It is active and supports the 151-D Electrical Substation. The septic system is constructed of reinforced concrete and has a drain field.

The 1607-D3 is not known to have rece ved hazardous or radioactive wastes, a) though it supports a facility where hazardous and/or radioactive materials may have been routinely handled and used. Of these, solvents and PCB contaminated oils are most likely to have been used, although only in very sma?l concentrations. They would have been generated by hand washing and small parts cleaning. It is unlikely that any radioactive materials ever eniered the facility. For consistency, the septic system is included in Table $5-i$.

Table 5-7. Septic Tank Systems.

\begin{tabular}{|c|c|c|}
\hline $\begin{array}{c}\text { SEPTIC TANR } \\
\text { DESIGNATION }\end{array}$ & $\begin{array}{l}\text { HANFORD } \\
\text { LOCATION }\end{array}$ & \multicolumn{1}{|c|}{ COMMENTS } \\
\hline 1607-D3 & $\begin{array}{l}\text { N91395 } \\
\text { W53250 } \\
\text { N91340 } \\
\text { W53250 }\end{array}$ & $\begin{array}{l}\text { Supported 151-0. The septic tank and drain field are locat- } \\
\text { and (ight the substation enclosure, part of a steel post } \\
\text { tank (Figure 5-16). }\end{array}$ \\
\hline
\end{tabular}


Figure 5-16. 151-D Septic Tank and Drain Field.

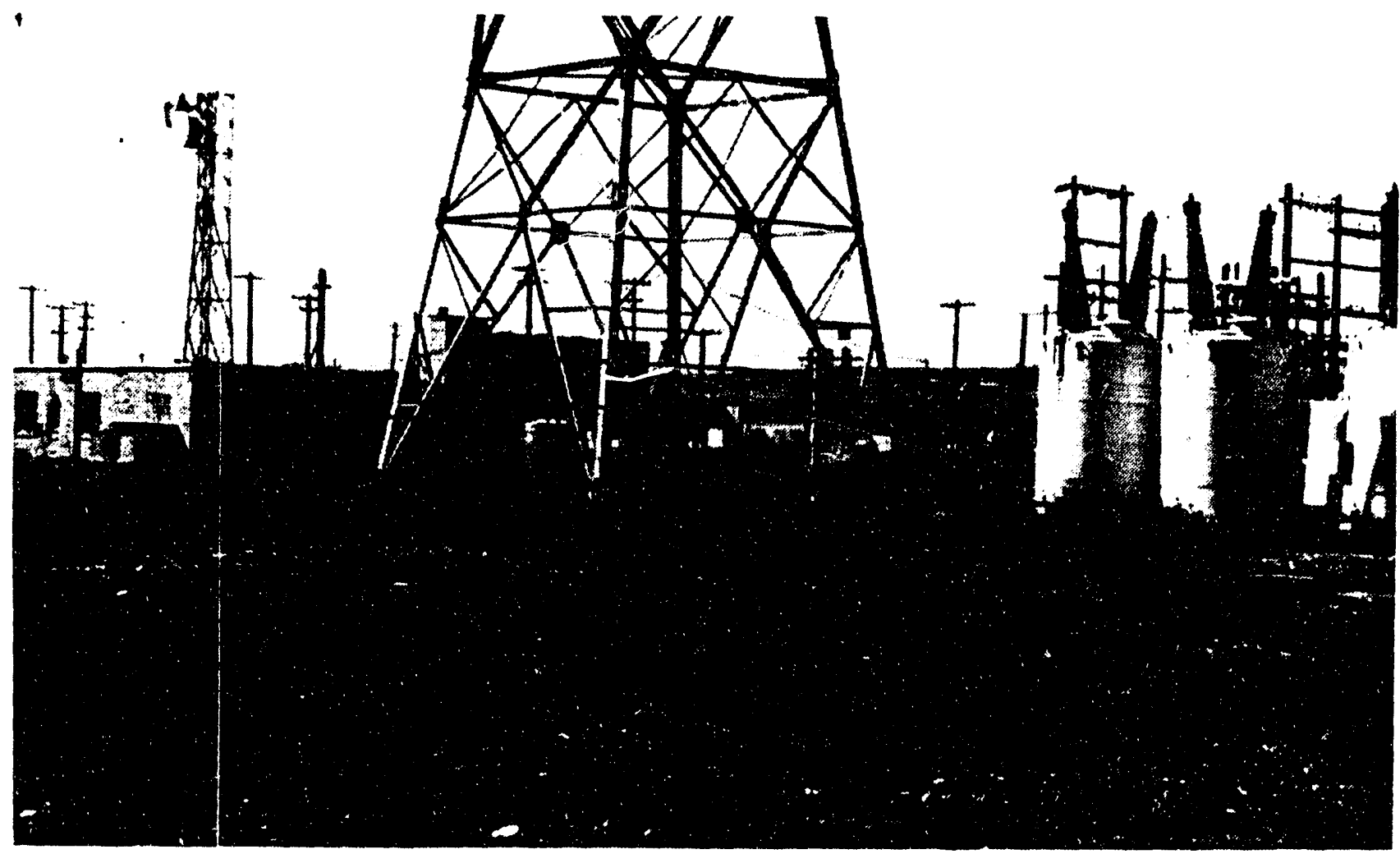

\subsection{UNDOCUMENTED WASTE SITE, TEMPORARY GARAGE AND GASOLINE DISPENSING STATION}

During construction of the water treatment facilities for the 105-DR Reactor, a temporary garage facility (TC-21) was built. On May 2, 1950, the garage was destroyed by a fire (GE 1952). There is potential for soil contamination at the location from gasoline, oils, and engine coolants. It is not known if there was an underground tank associated with this facility (generally temporary garages only housed aboveground storage tanks). The location of the garage is unknown.

\subsection{UNDOCUMENTED LIQUID WASTE SITE, PUMPING STATION SODIUN DICHROMATE/ACID RAILCAR AND TRUCK UNLOAD STATION AND FRENCH DRAIN}

The sodium dichromate/acid pumping station is located just south of the 184-D building next to the railroad tracks. A 3-in. underground line provided the ability to pump solutions to storage tanks located outside 185-D and 190DR.

A 3-ft-diameter french drain located at the site supported the flushing and draining of hoses and lines that connected to the tank cars. This is a significant waste site because undiluted volumes of sodium dichromate and acid solutions were dumped directly to the soil column at this location (Figure 517). 
Figure 5-17. Sodium Dichromate Pumping Station.

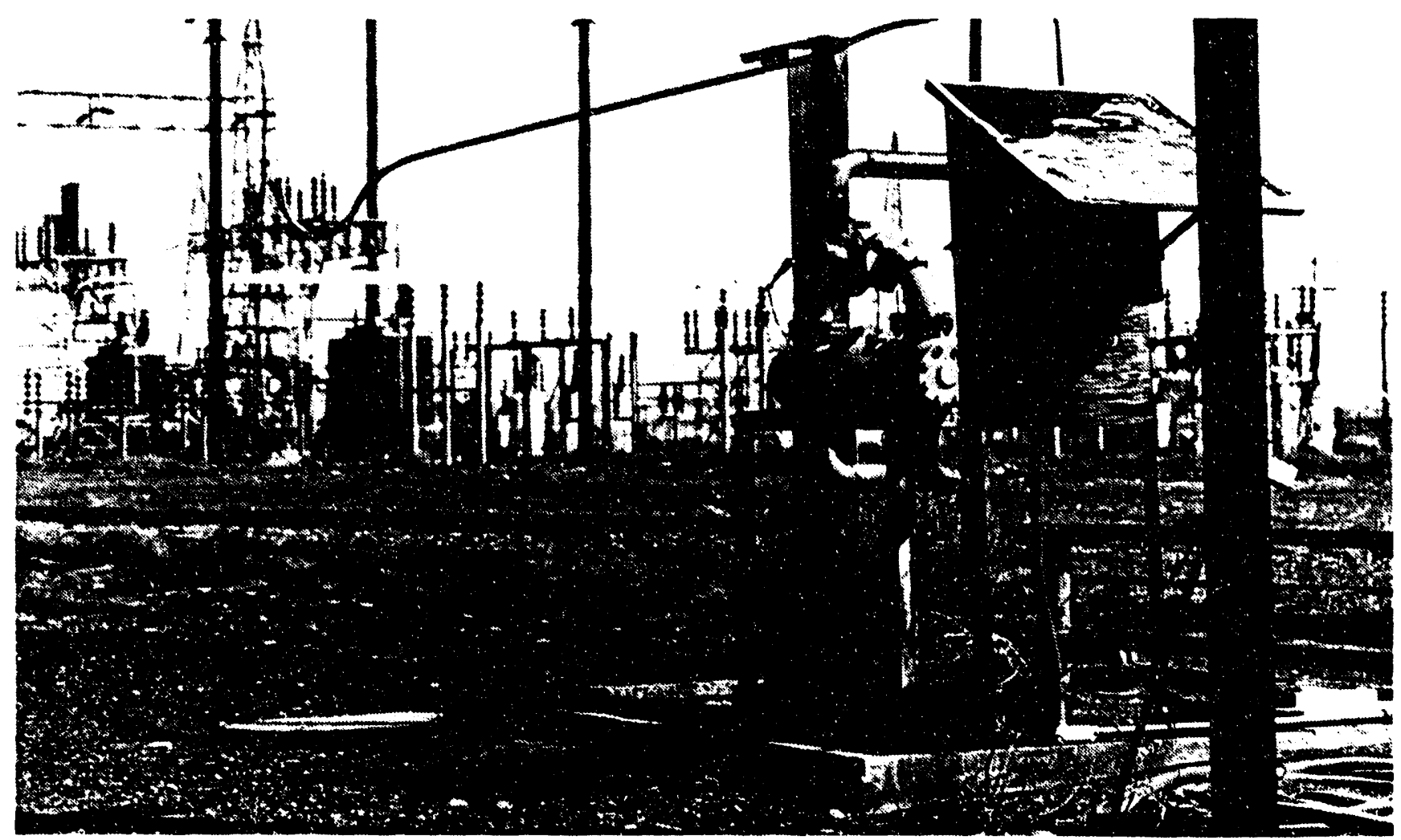

\subsection{0-DR-2 AREA SITE DESCRIPTIONS AND BUILDING DIRECTORY}

This section describes facilities and areas not mentioned in the preceding sections. Some of these facilities may be important from a waste standpoint and are identified as such in Table 5-8, concerning facilities that have potential for hazardous or radioactive material contamination. Table 5-9 provides a list of facilities and comments about the facilities concerning the known disposition of various sites and facilities not previously mentioned.

Table 5-8. Potentially Contaminated Facilities.

\begin{tabular}{||c|c|c||}
\hline FACILITY & $\begin{array}{c}\text { HANFORD } \\
\text { LOCATION }\end{array}$ & \multicolumn{1}{|c|}{ COMMENTS } \\
\hline $117-D R$ & $\begin{array}{l}\text { N90995 } \\
\text { W52870 }\end{array}$ & $\begin{array}{l}\text { Filter Building. Potential radioactive contamination, located at } \\
\text { W91200 W52800 (PNL 1991) }\end{array}$ \\
\hline $151-D$ & $\begin{array}{l}\text { N91350 } \\
\text { W53525 }\end{array}$ & $\begin{array}{l}\text { Electrical Substation. Potential for PCB and solvent contamina- } \\
\text { tion in soils and drains }\end{array}$ \\
\hline $183-D R^{*}$ & $\begin{array}{l}\text { N91075 } \\
\text { W54260 }\end{array}$ & Filter Plant, Head House, Sedimentation and Coagulation Basins \\
\hline $190-D R$ & $\begin{array}{l}\text { N90910 } \\
\text { W53550 }\end{array}$ & $\begin{array}{l}\text { Main Pump House. Potential for radioactive, chemical and solvent } \\
\text { contemination }\end{array}$ \\
\hline
\end{tabular}




\section{* 183-DR FILTER PLANT}

The 183-DR filter plant was constructed in 1950 to supply treated cooling water to the 105-DR Reactor. As part of the deactivation of 105-DR, the flocculating basins were cleaned and the silt flushed from them. Radiation survey of the flocculating basins after cleaning revealed beta-gamma contamination levels of less than $500 \mathrm{c} / \mathrm{m}$ (Winship 1965).

Chemical storage silos and a large transformer were removed sometime before demolition (1978). The demolition debris were buried in the clear wells and sedimentation basins and then covered by backfill. The area of the facility that was used for chemical storage, including sodium dichromate solutions and other water treatment chemicals, has the potential for contamination.

Table 5-9. Low Potential for Contamination Facilities.

\begin{tabular}{|r|c|c|}
\hline FACILITY & $\begin{array}{c}\text { HANFORD } \\
\text { LOCATION }\end{array}$ & COMMENTS \\
\hline $1702-D R$ & $\begin{array}{l}\text { N91530 } \\
\text { W52910 }\end{array}$ & Exclusion Area Badge House \\
\hline
\end{tabular}




\subsection{0-DR-3 OPERABLE UNIT}

This section describes the 100-DR-3 Operable Unit, which encompasses the southern-most portion of the 100-D/DR Area. Its northern boundaries are bounded by the 100-DR-2 Operable Unit to the eastern side of the exclusion area fence and the south boundary of the 100-DR-1 Operable unit. The eastern and southern boundaries are the 100-D Area perimeter road. The operable unit encompasses 13 waste sites, 7 of which are included in the Tri-Party Agreement (Ecology et al. 1989). These sites include decommissioned ponds, burial grounds, burn pits, and septic tank systems (Appendix F).

The relative 1ocations of 100-DR-1, 100-DR-2, and 100-DR-3 are shown in Appendix $B(B-3)$. A map of the 100-DR-3 Operable Unit can also be found in Appendix $B(B-6)$. Additional figures (B-7, $B-8, B-9$, and $B-10)$ are included in Appendix $B$ to provide clarity for each waste type described.

Table 6-1 identifies the sites for which a PNL HRS Migration score has been established; not all of the waste sites located within the 100-DR-3 Operable Unit have an HRS score.

Table 6-1. Hazard Ranking System Migration Score.

\begin{tabular}{|c|c|}
\hline WASTE SITE NUMBER & HRS MIGRATION SCORE \\
\hline $118-D-1$ & 1.84 \\
\hline $118-D-2$ & 2.76 \\
\hline $118-D-3$ & 2.76 \\
\hline $118-D-4$ & 1.84 \\
\hline $118-D R-1$ & 1.84 \\
\hline $128-D-1$ & 0.13 \\
\hline
\end{tabular}

(Stenner et at 1988)

Each waste site is described separately in Sections 6.1 through 6.12.

\subsection{6-DR-10 PIT (105-DR FUEL STORAGE BASIN CLEANOUT PERCOLATION POND)}

The 116-DR-10 pit is an inactive liquid waste site that operated from October to November 1984. The 80 - by 50 - by 6 -ft-deep pit was located at Hanford coordinates N91075 W52200, which is about $150 \mathrm{~m}$ east and slightly south of the 105-DR Reactor Building, just outside the HPS AC-5-40 permanent markers. The 116-DR-10 pit received processed water from the 105-DR fuel storage basin. The site was also known as the 105-DR fuel storage discharge pond and as the 105-DR pond. 
The pond was an open excavated pit located in a natural depression (WHC 1991). During the cleanout of the 105-DR fuel storage basin, the radiologically contaminated shielding water was processed through an ion exchange process filtration system (Miller and Steffes 1986). Composite samples were taken to ensure that radionuclide concentrations were below the release criteria given in Table II of DOE Order 5480.1 prior to discharge to the pit.

Although the water was cleaned to applicable release limits, minute quantities (below release limits) of radionuclides remaining in the water accumulated in the soil at some low points of the pit floor (Beckstrom 1987). No known hazardous substances were present in the water; however, chemical analysis was not a standard practice during that period, and there is no evidence that one was performed. It should be noted that water removed from the 1608-DR (132-DR-1) is believed to be comparable to the storage basin water, and EP-TOX testing results for the 1608-DR water were negative (WHC 1991).

Upon closure, contaminated soil was removed from the pond area using flat nosed shovels and was packaged for burial in the 200 West burial grounds. The site was released using ARCL methodology. "The mean concentration for alpha contamination did not meet the unrestricted release criteria of $1 \mathrm{pCi} / \mathrm{m}$ for dispersed activity outlined in Table II-1 of UNI-M-31, Environmental Control Manual. Therefore, the enhanced ARCL methodology was used to calculate the worst-case dose to an individual through the use of the Resident-Home Garden (RHG) Scenario and the Agricultural (AG) Scenarion. The post-decontamination soil samples constituted a potential dose, to an individual, of $7.6 \mathrm{mrem} / \mathrm{yr}$, with a UCL of $10 \mathrm{mrem} / \mathrm{yr}$. All calculations were based on conservative assumptions and demonstrate that the decommissioning activities were conducted with a potential dose to a maximally exposed individual well below the ARCL limit of $25 \mathrm{mrem} / \mathrm{yr}$ (Beckstrom 1987).

The site was backfilled and graded to match the natural terrain. It appears today as a shallow (less than $2 \mathrm{ft}$ deep) excavation in which vegetation is slowly reestablishing ground cover (Figure 6-1).

This waste site has not been assigned an HRS Migration score.

\subsection{8-D-1 (100-D BURIAL GROUND KUMBER 1)}

The 118-D-1 is an inactive solid waste site that operated from 1944 to 1967. The 450- by $375-\mathrm{ft}$ site was located at Hanford coordinates $\mathrm{N} 90380$ W53205 (northwest corner), which is about $900 \mathrm{ft}$ south of the 105-DR Building. The burial ground was used to dispose of irradiated reactor parts, dummies, thimbles, rods, gun barrels, and other contaminated solid waste.

The burial ground contains many trenches running north and south. Typically, the trenches were 300 by 20 by $20 \mathrm{ft}$ deep with a $20-\mathrm{ft}$ space between them. The unit received an estimated $10,000 \mathrm{~m}^{3}$ of wastes, of which 10 $\mathrm{m}^{3}$ was metallic. The principal radionuclide was ${ }^{60} \mathrm{Co}: 1.000 \mathrm{e}+000$, measured in curies decayed through April 1, 1986. The burial ground was divided into four sections to allow grouping of like wastes in each section (Hanford Drawing H$1-4046)$. 
Figure 6-1. 105-DR Fuel Storage Basin Cleanout Pond.

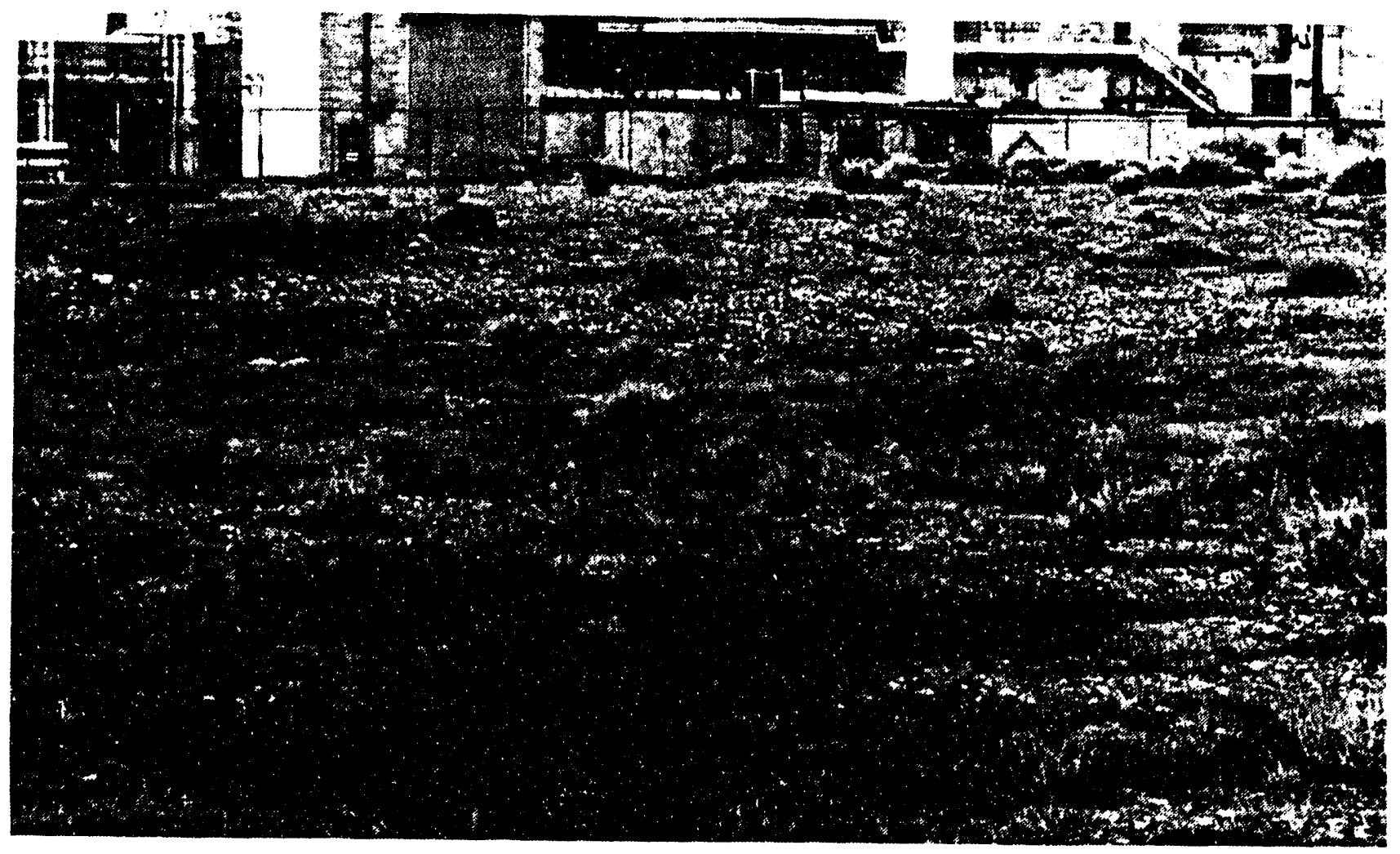

The area appears today as a vegetation-free, cobble-covered field. It is bordered by permanent concrete markers and is posted with Underground Radioactive Material warning signs. The western section of the site is elevated about $2 \mathrm{ft}$ above the rest of the area. A terraced dirt mound, located in the southeast corner of the site, was constructed prior to 1987 as part of a feasibility study for the revegetation of burial grounds. It was terraced to determine the minimum soil depth required to sustain plant growth. Currently the 118-D-1 and mound are treated annually with defoliants (Figure 6-2).

This waste site has an HRS Migration score of 1.84 (Stenner et al 1988).

\subsection{8-D-2 (100-D BURIAL GROUND NUMBER 2)}

The $118-D-2$ is an inactive solid waste site that operated from 1949 to 1970. The 1,000 - by 357 - by 20 -ft-deep site is located at Hanford coordinates N90582 W55652 (northwest corner) (Stenner et al 1988), which is about 2,700 ft southwest of the 105-DR Building (PNL 1991). This burial ground was used for the disposal of an estimated $10,000 \mathrm{~m}^{3}$ of miscellaneous contaminated solid waste, irradiated dummies, splines, rods, thimbles, and gun barrels. It is divided into four sections to allow grouping of like wastes (Hanford Drawing
$\mathrm{H}-1-4046)$.

Beginning in April 1966, 100-N Area low-level radioactive solid wastes were also buried at this site. 
Figure 6-2. 100-D Area Burial Ground Number One.

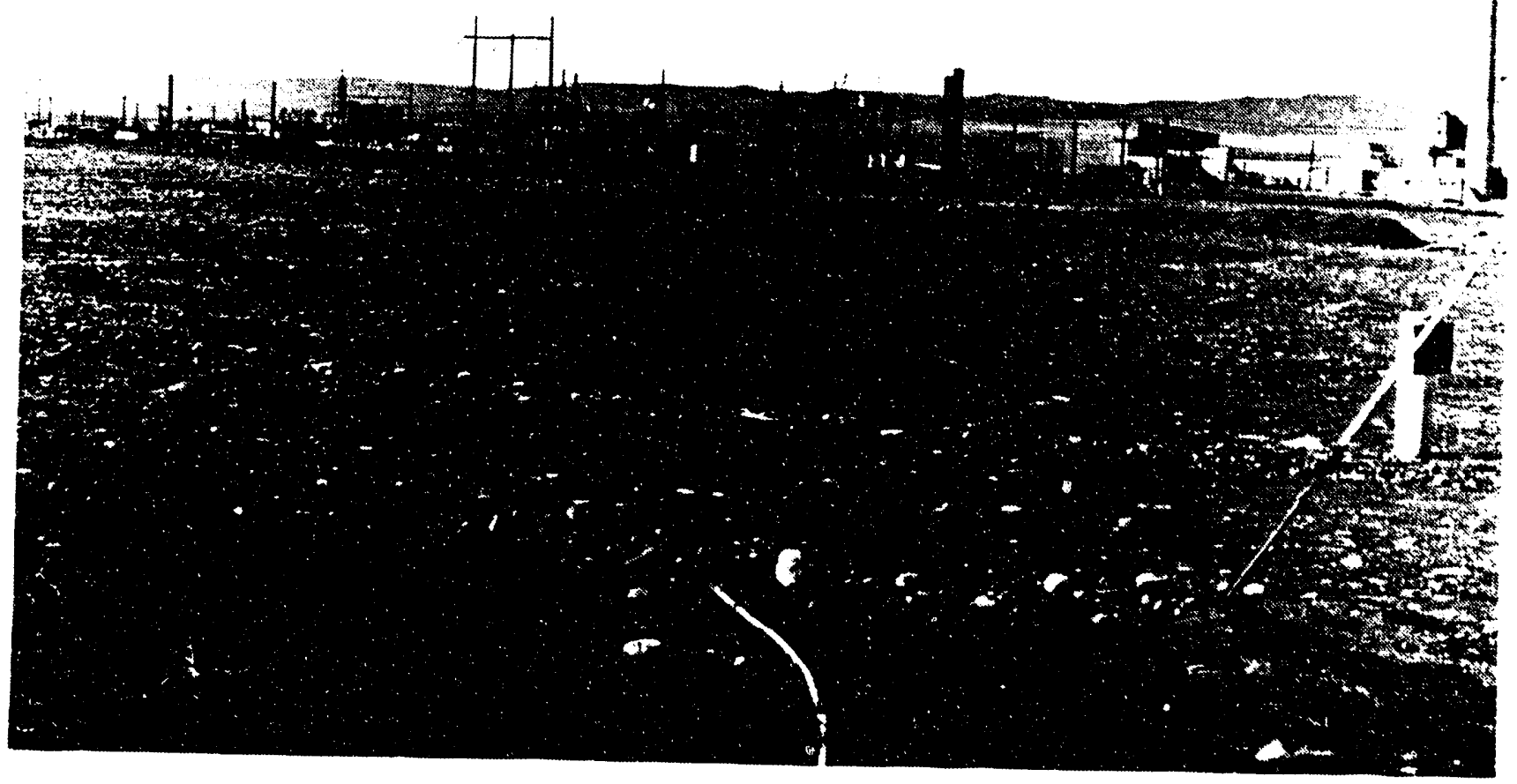

The site contained many trenches running east-west and five disposal pits. The trenches are $66 \mathrm{ft}$ wide at the surface, $20 \mathrm{ft}$ wide at the bottom, and 20 $\mathrm{ft}$ deep. Each site is composed of two smail pits, constructed with railroad ties, with interior dimensions of about 6 by $6 \mathrm{ft}$, placed within an excavation 24 by $24 \mathrm{ft}$ deep. All were covered with $6 \mathrm{ft}$ of soil.

The radionuclide content in curies decayed through April 1, 1986 includes the following:

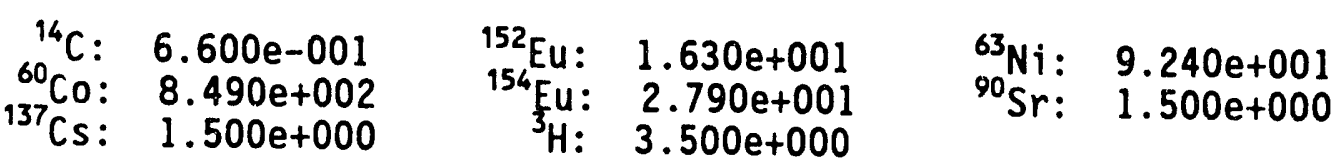

(Stenner et al 1988)

Estimates of the metallic wastes disposed of at this burial site can be seen in Table 6-2. 
Table 6-2. Metallic Wastes.

\begin{tabular}{lr} 
Aluminum Tubes: & $16329.00 \mathrm{~kg}$ \\
Aluminum Spacers: & $36287.00 \mathrm{~kg}$ \\
Lead-Cadmium Poison Slugs: & \\
& \multicolumn{1}{c}{ Lead: } \\
\multicolumn{1}{c}{ Cadmium: } & $89040.00 \mathrm{~kg}$ \\
Graphite: & $3719.00 \mathrm{~kg}$ \\
Desiccant: & $54.00 \mathrm{~kg}$ \\
Aluminum Poison Slugs: & $14.00 \mathrm{~kg}$ \\
Boron Poison Splines: & $5987.00 \mathrm{~kg}$ \\
Lead: & $816.00 \mathrm{~kg}$ \\
Mercury: & $58966.00 \mathrm{~kg}$ \\
Miscellaneous Metallic Waste: & $0.00 \mathrm{~kg}$ \\
& $16329.00 \mathrm{~kg}$
\end{tabular}

(Stenner et al 1988)

Site fire personnel report that there was a large fire in this burial ground sometime around 1960 . It was difficult to extinguish and required large volumes of water (several tank truck loads) to put out. Contaminants could potentially have been washed to the soil column beneath this burial
ground.

The site appears today as a large, vegetation-free, cobble-covered field surrounded by permanent concrete markers that are posted with Underground Radioactive Material warning signs. Much of the burial ground surface is about $1 \mathrm{ft}$ above the grade of the surrounding area (Figure 6-3).

Figure 6-3. 100-D Area Burial Ground Number Two.

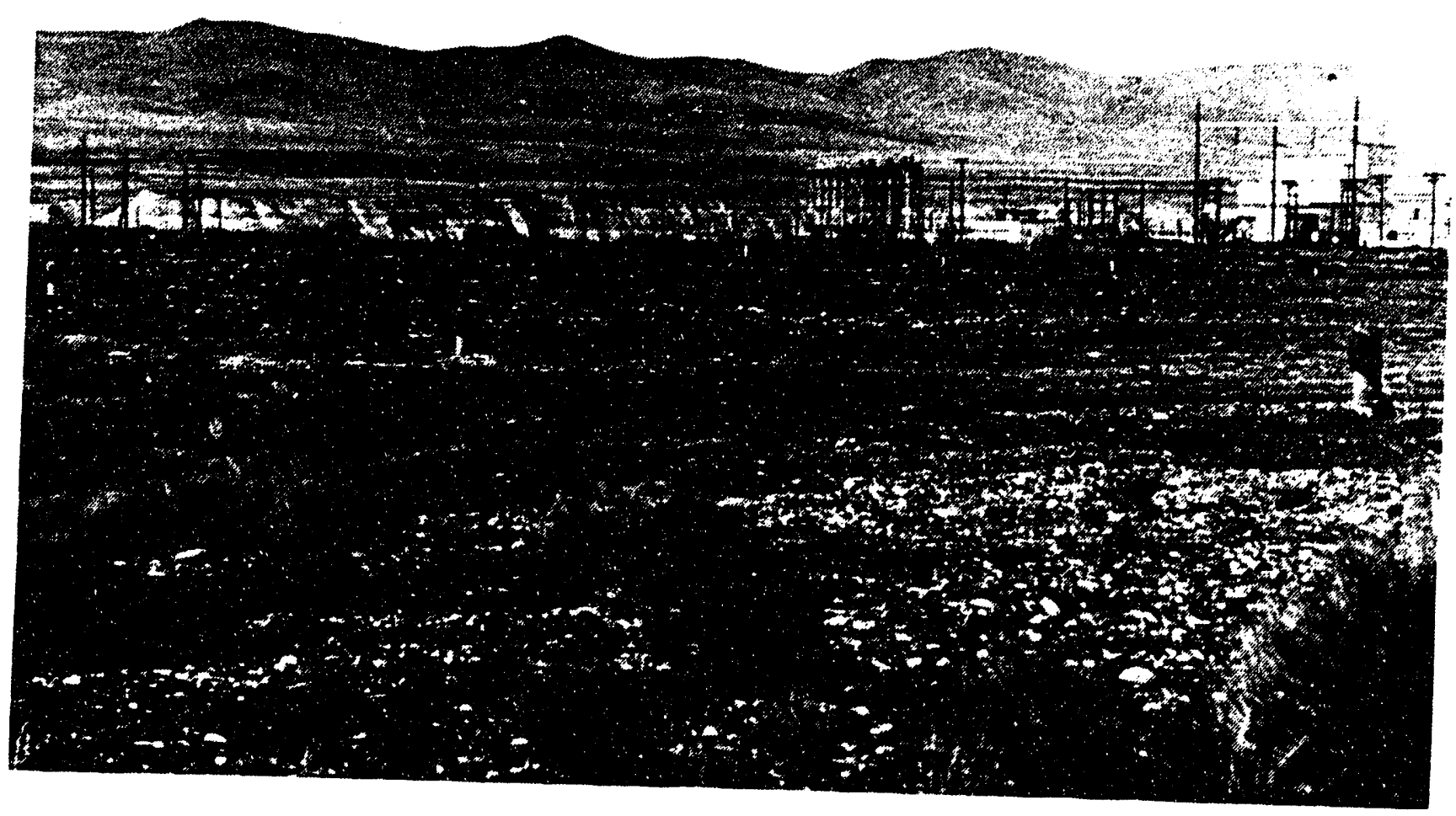


This waste site has an HRS Migration score of 2.76 (Stenner et al 1988).

\subsection{8-D-3 (100-D BURIAL GROUND NUMBER 3)}

The 118-D-3 is an inactive solid waste site that operated from 1956 to 1973. This burial ground was located at Hanford coordinates N91222 W52543 (northwest corner) (ERDA 1975), which is about $350 \mathrm{ft}$ east of the 105-DR building (PNL 1991).

Typically, trenches were 200 by 20 by $20 \mathrm{ft}$ deep and the spacing between trenches was not uniform (Stenner et al 1988). This burial ground was divided up into five sections to allow grouping of like wastes (Hanford Drawing H-14046). It al so contained a burning pit that was used for the disposal of low level radioactive combustible wastes (Owen 1967).

This burial ground was used for the disposal of miscellaneous contaminated solid wastes and irradiated dummies, splines, rods, thimbles, and gun barrels. It received an estimated $100 \mathrm{~m}^{3}$ of wastes. The principal radionuclides decayed through April 1, 1986 include the following:

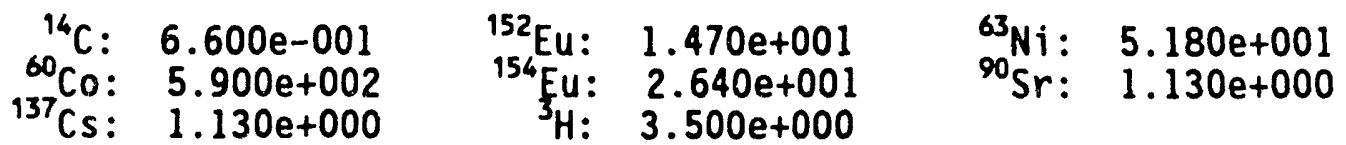

(Stenner et al 1988)

Estimates of the metallic wastes disposed of at this burial site can be seen in Table 6-3.

Table 6-3. Metallic Wastes.

\begin{tabular}{lr} 
Aluminum Tubes: & $16329.00 \mathrm{~kg}$ \\
Aluminum Spacers: & $36287.00 \mathrm{~kg}$ \\
Lead-Cadmium Poison Slugs: & \\
\multicolumn{1}{c}{ Lead: } & $89040.00 \mathrm{~kg}$ \\
\multicolumn{1}{c}{ Cadmium: } & $3719.00 \mathrm{~kg}$ \\
Graphite: & $54.00 \mathrm{~kg}$ \\
Desiccant: & $14.00 \mathrm{~kg}$ \\
Aluminum Poison Slugs: & $5987.00 \mathrm{~kg}$ \\
Boron Poison Splines: & $816.00 \mathrm{~kg}$ \\
Lead: & $58966.00 \mathrm{~kg}$ \\
Mercury: & $0.00 \mathrm{~kg}$ \\
Miscellaneous Metallic Waste: & $16329.00 \mathrm{~kg}$
\end{tabular}

(Stenner et al 1988)

The 118-D-3 was also used for the disposal of $100-N$ solid wastes, extending the eastern boundary.

Additional solid wastes buried in or very near to this burial ground are considered a part of it. A short summary of these additional burial grounds follows. 
- Minor Construction burial ground number 2 was a trench dug in 1953 to receive contaminated thimbles, rod guides, and miscellaneous waste removed from the 105-DR Reactor during an extended Ball $3 X$ outage. The contaminated wastes were then covered with $6 \mathrm{ft}$ of dirt and the location was marked with cement monuments (Heid 1956). The concrete monuments are no longer in place.

- A small trench was dug in March 1954 to receive effluent water from the number one DR west effluent expansion box during repairs. It was described as being a "grave" (a trench that was dug to receive a specific waste and covered over soon after the waste was received) (Clukey 1956). It is assumed that the trench was dug very near the expansion box and should be located in the northwest corner of the burial ground (Figure 6-4).

Figure 6-4. Suspect Liquid Waste Site.

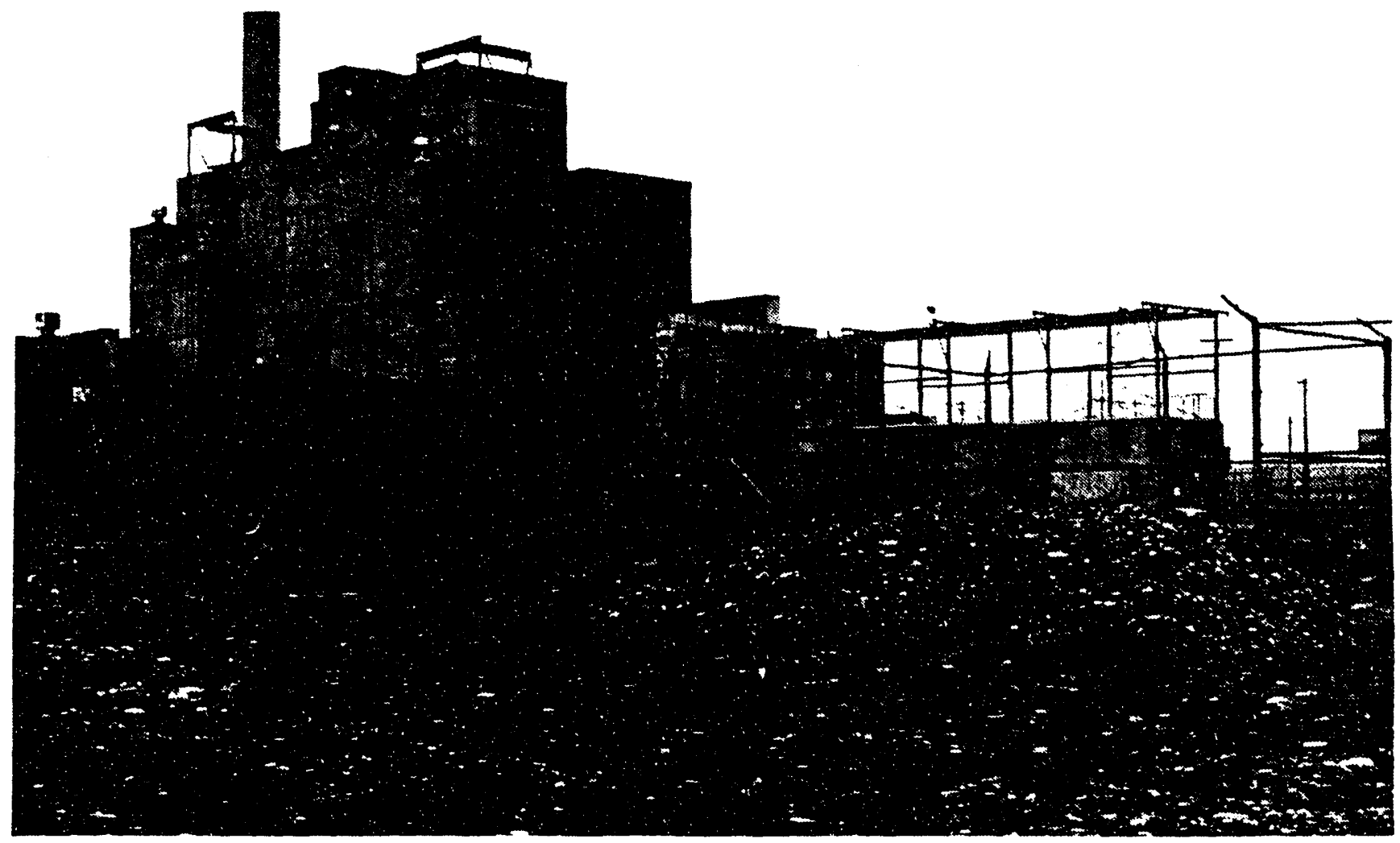

The site appears today as a vegetation-free cobble field surrounded by permanent concrete markers and posted with Underground Radioactive Material signs. There is also a small sign identifying the site as the 118-D-3 burial ground (Figure 6-5).

This waste site has an HRS Migration score of 2.76 (Stenner et al 1988). 
Figure 6-5. 118-D-3 Burial Ground.

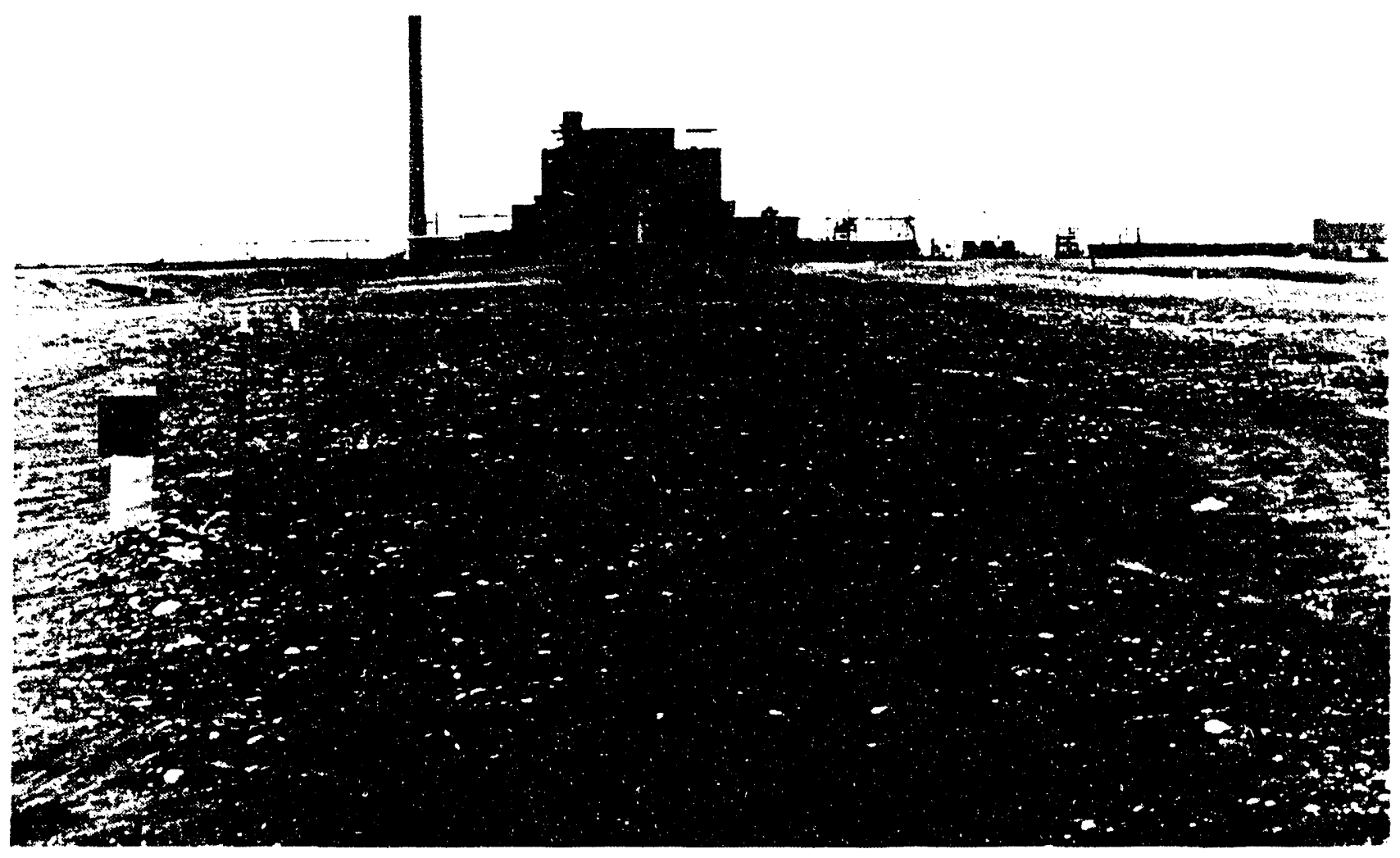

\subsection{8-D-4 (CONSTRUCTION BURIAL GROUND)}

The 118-D-4 is an inactive solid waste burial site that operated from 1953 to 1967. The $600-$ by $200-$ by $20-\mathrm{ft}$-deep site is located at Hanford coordinates N91900 W52100 (Stenner et al 1988), which is about $200 \mathrm{ft}$ southeast of the 105-D Building (PNL 1991). This burial ground was used for the disposal of contaminated material (mainly reactor components and hardware) generated during various reactor modifications from the 105-D Reactor Building. The site contains many nonuniform trenches (Stenner et al 1988).

The burial site received an estimated $20,000 \mathrm{~m}^{3}$ of wastes. The principal isotope was ${ }^{60} \mathrm{Co}$, with $1.000 \mathrm{E}^{+000}$ curies decayed through Apri1 1, 1986.

The 105-D Ball $3 \times$ burial ground is considered a part of this site and is located near the northeast corner. Three square concrete markers mark its location (WHC 1991) (Figure 6-6).

This waste site has an HRS Migration score of 1.84 (Stenner et al 1988). 
Figure 6-6. 118-D-4 Burial fround.

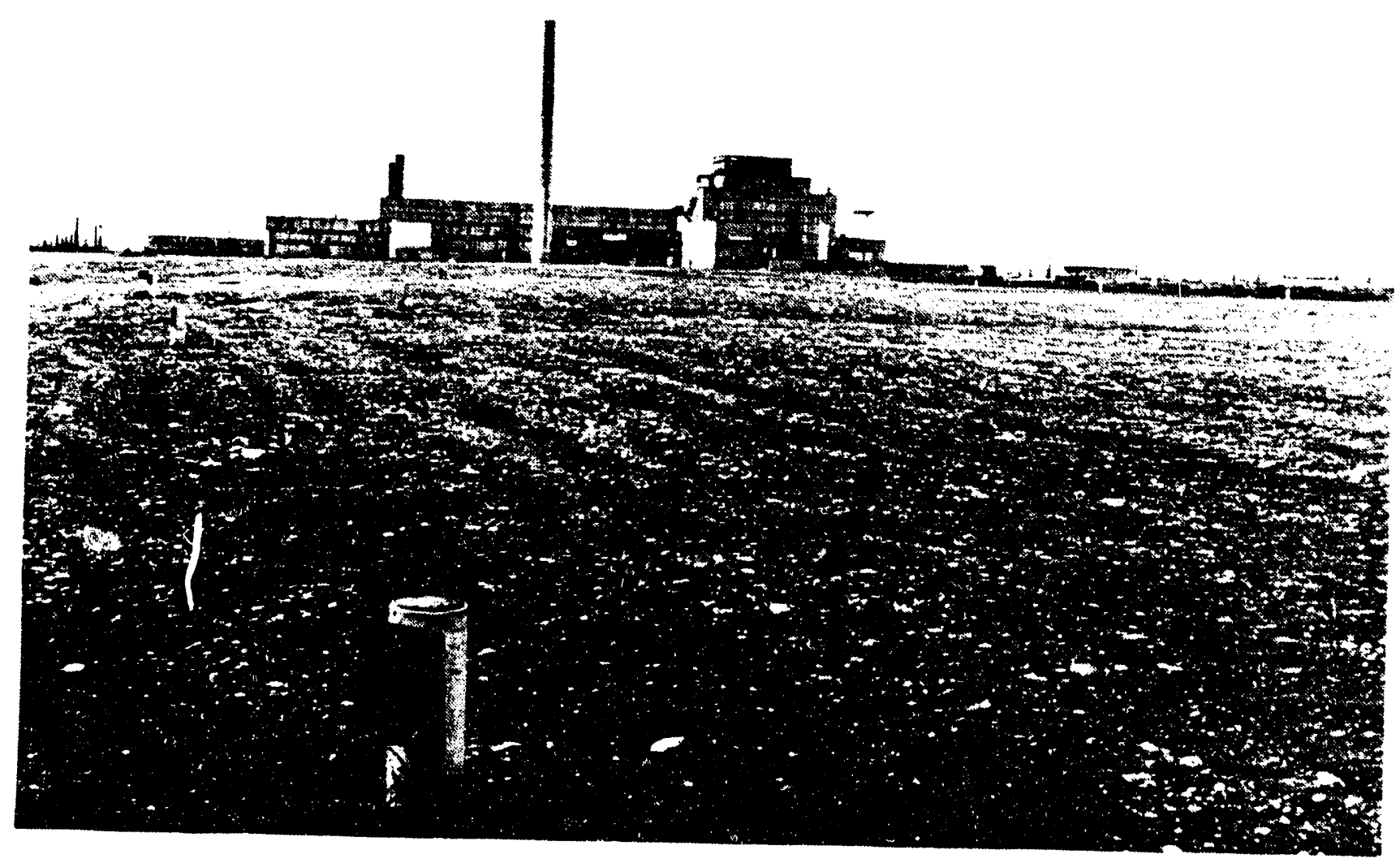

\subsection{8-DR-1 (105-DR GAS LOOP BURIAL GROUND)}

The 118-DR-1 is an inactive solid waste site that operated from 1963 to 1964. It is located at Hanford coordinates N90400 W52800 (Stenner et a] 1988 ), which is $600 \mathrm{ft}$ south of the 105-DR Building (PNL 1991). The 125- by 75- by 15-ft-deep burial ground was used for the disposal of irradiated metal assemblies from the 105-DR gas loop.

The site contains a single north-south trench that was originally a gunnite-lined pool. The pool was water-filled and used to perform examinations and sectioning of test assemblies.

There is an estimated $20 \mathrm{~m}^{3}$ of metaliic waste buried at the site. The principal radionuclide is ${ }^{60} \mathrm{Co}$, with $1.000 \mathrm{E}^{+000}$ curies decayed through April 1 ,

The site appears as a vegetation-free, cobble-covered field. Support structures for the test assembly removal pipe are in place at the north and south erids of the site (Figure 6-7).

This waste site has an HRS Migration score of 1.84 (Stenner et al 1988). 
Figure 6-7. 100-DR Gas Loop Burial Ground.

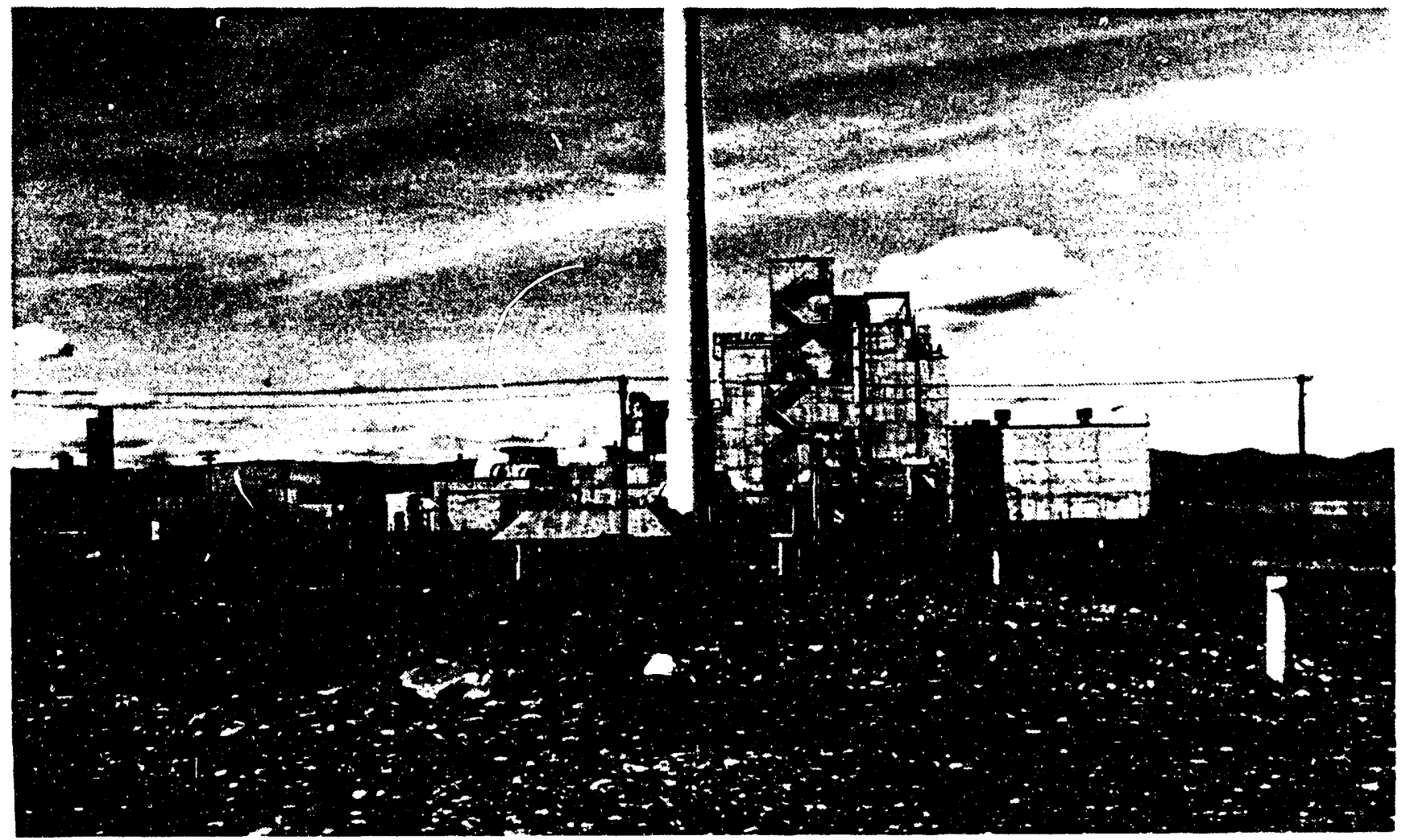

\subsection{8-D-1 (100 D/DR BURNING PIT)}

The 128-D-1 is an inactive solid waste site that operated from 1944 to 1967. The 100- by 100- by 10-ft-deep site is located at Hanford coordinates N92000 W51000 (Kiser 1988). It was used for the disposal of an estimated $40,000 \mathrm{~m}^{3}$ of nonradioactive combustible materials such as paint waste, office waste, and chemical solvents (Stenner et al 1988). This site was identified by a retired truck driver who used to haul material to the location.

During site inspections conducted for this report, the exact location of this burn pit could not be found, although there was some evidence of a burn pit at the site location (wood ash material and pieces of transite siding) (Figure 6-8).

This waste site has an HRS Migration score of 0.13 (Stenner et al 1988).

\subsection{7-D SEPTIC TANKS AND ASSOCIATED DRAIN FIELDS}

Three septic tanks are located in the 100-DR-3 Operable Unit. They are inactive systems constructed of reinforced concrete with associated drain fields. They are not known to have received hazardous or radioactive wastes, although they may have received materials associated with cleaning solvents and materials that were likely used in the facilities they supported. One has been assigned a designation number and the other two are identified as "unnumbered" in Table 6-4. 
WHC-SD-EN-TI-181, Rev. 0

Figure 6-8. Suspect Location of the 128-D-1 Burn Pit.

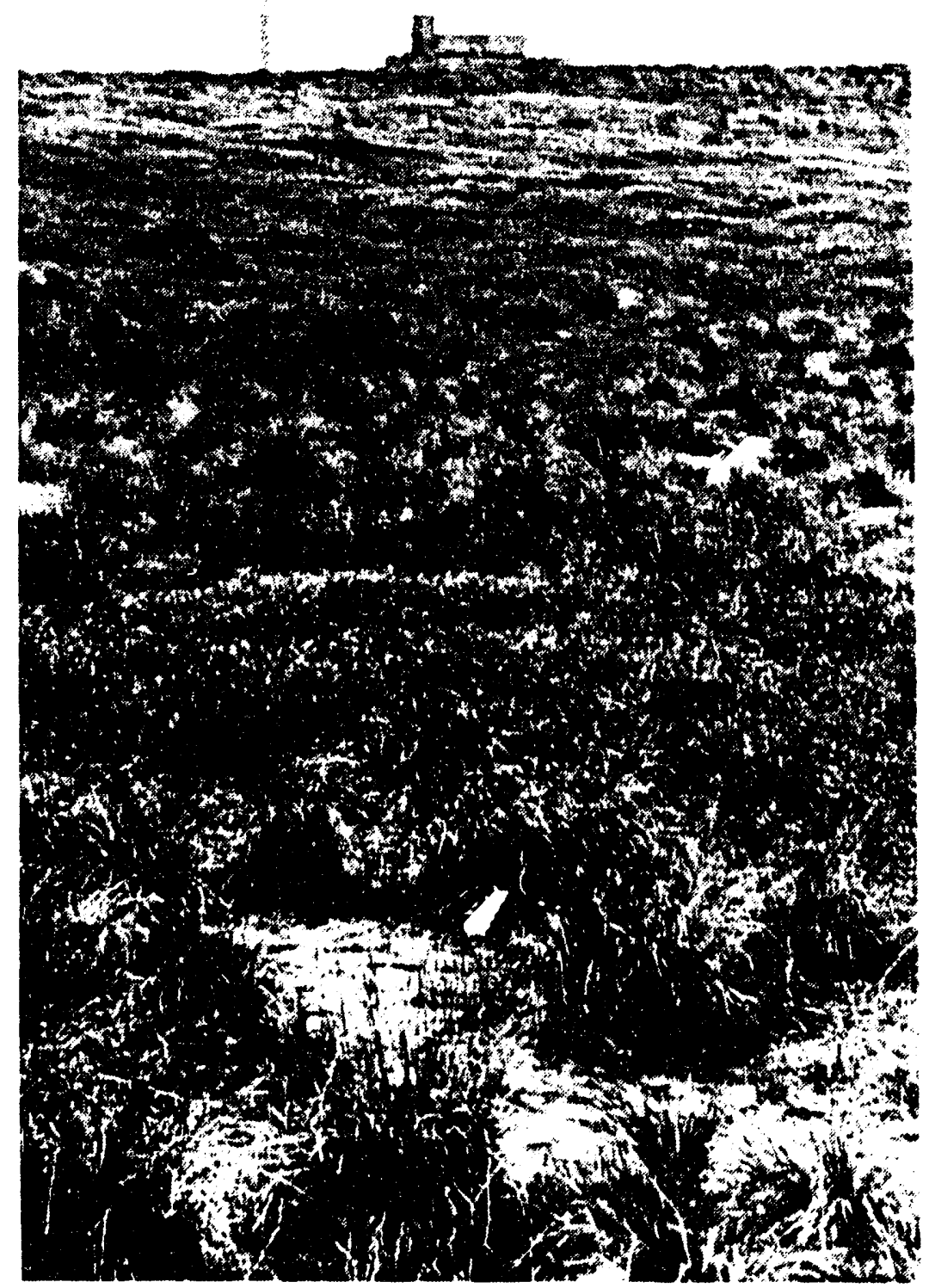


WHC-SD-EN-TI-181, Rev. 0

Table 6-4. Septic Systems.

\begin{tabular}{|c|c|c|}
\hline $\begin{array}{l}\text { SEPTIC TANK } \\
\text { DESIGNATION }\end{array}$ & $\begin{array}{l}\text { HANFORD } \\
\text { LOCATION }\end{array}$ & COMMENTS \\
\hline $\begin{array}{r}1607-D 1 \\
\text { DRAIN FIELD }\end{array}$ & $\begin{array}{l}\text { N89740 } \\
\text { W50280 } \\
\text { N90155 } \\
\text { W50330 } \\
\end{array}$ & $\begin{array}{l}\text { Supported } 1701-D \text { and } 1709-0 \text {. The tank is not evident on the } \\
\text { surface, there is a large cobble field (about } 50 \text { yards north } \\
\text { of the power line) that is the drain field for this septic } \\
\text { system (Figure 6-9) }\end{array}$ \\
\hline UNNUMBERED & $\begin{array}{l}\text { N90900 } \\
\text { W51900 }\end{array}$ & $\begin{array}{l}\text { Supported temporary construction facilities and overflow from } \\
\text { the high tanks located at } 100-D R \text { and the } 100-0 R \text { Reactor. The } \\
\text { system consisted of an IMHOFF tank and drain field. The tank } \\
\text { is a concrete structure with a steel lid surrounded by a steel } \\
\text { pipe barricade fence. There are two access cover plates and } \\
\text { three vents on the top cover plate. There is standing liquid } \\
\text { in the tank bottam. The drain field is about } 100 \text { yards north- } \\
\text { oast of the tank and is a large pit surrounded by a steel post } \\
\text { and light chain barricade that is unmarked (a sign found on } \\
\text { the ground near the fence ident ifies the area as a septic } \\
\text { drain field). A large concrete weir box is located on the west } \\
\text { side that has a deteriorated wooden lid. The pit bottom is a } \\
\text { cobble surface. A dispersion manifold lays on the surface } \\
\text { that has been capped. There are several small access covers } \\
\text { to the lines leading to this septic system: three are located } \\
\text { south and east of the } 100-D R \text { Reactor Facility outside the } \\
\text { exclusion area fence and two more are located within the 100- } \\
\text { DR-2 Operable Unit to the south west and south of the 100-DR } \\
\text { Reactor Facility. These access covers are surface level con- } \\
\text { crete boxes with a steel lid rectangular or square in shape } \\
\text { (Figures } 6-10 \text { and } 6-11 \text { ) }\end{array}$ \\
\hline UNNUMBERED & $\begin{array}{l}\text { N89380 } \\
W 52870\end{array}$ & $\begin{array}{l}\text { Supported Construction Badgehouse before relocation (H-1- } \\
8090) \text {. It is located about } 40 \text { yds. south of the roadway and } 25 \\
\text { ft northeast of small soil pile. There is a } 4-\text { in. concrete } \\
\text { vent pipe and nearby depression that most likely is the } \\
\text { septic tank, al though the tank is not evident on the surface. } \\
\text { (Figure } 6-12 \text { ) }\end{array}$ \\
\hline
\end{tabular}


Figure 6-9. 100-D Area Patrol and Fire Station.

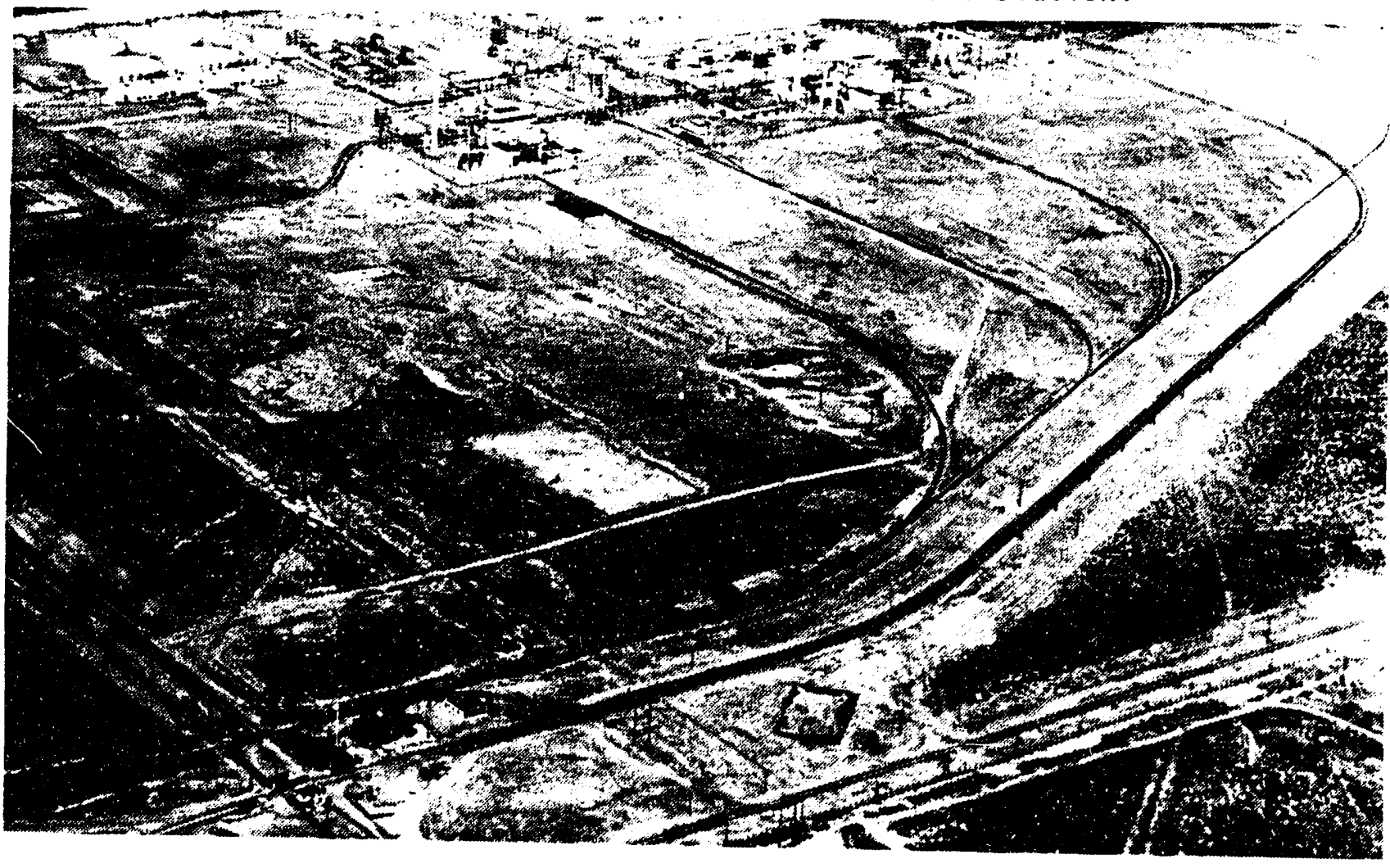

Figure 6-10. Undocumented Septic Tank (IMHOFF Tank).

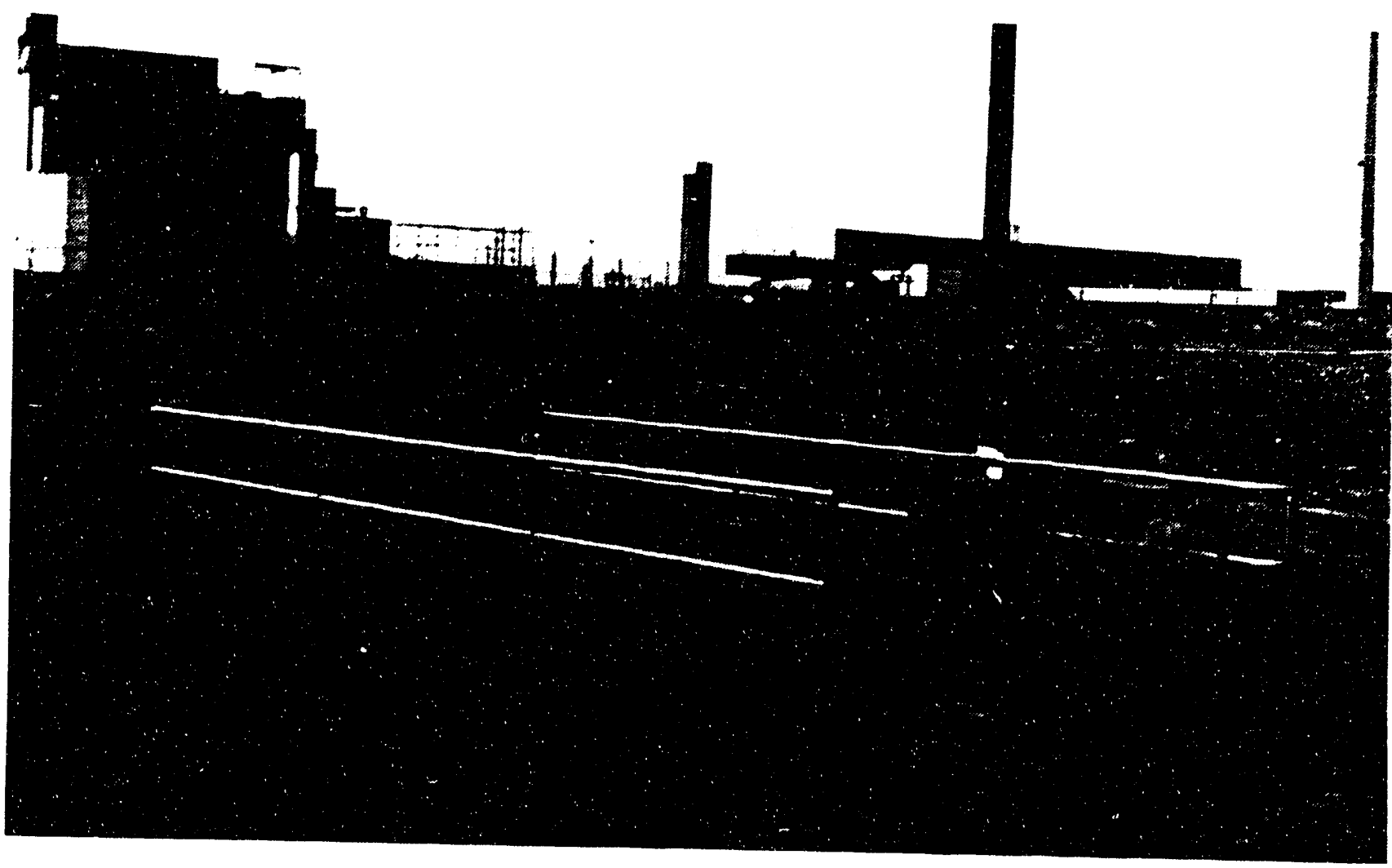




$$
\text { WHC-SD-EN-TI-181, Rev. } 0
$$

Figure 6-11. Undocumented Septic Drain Field.

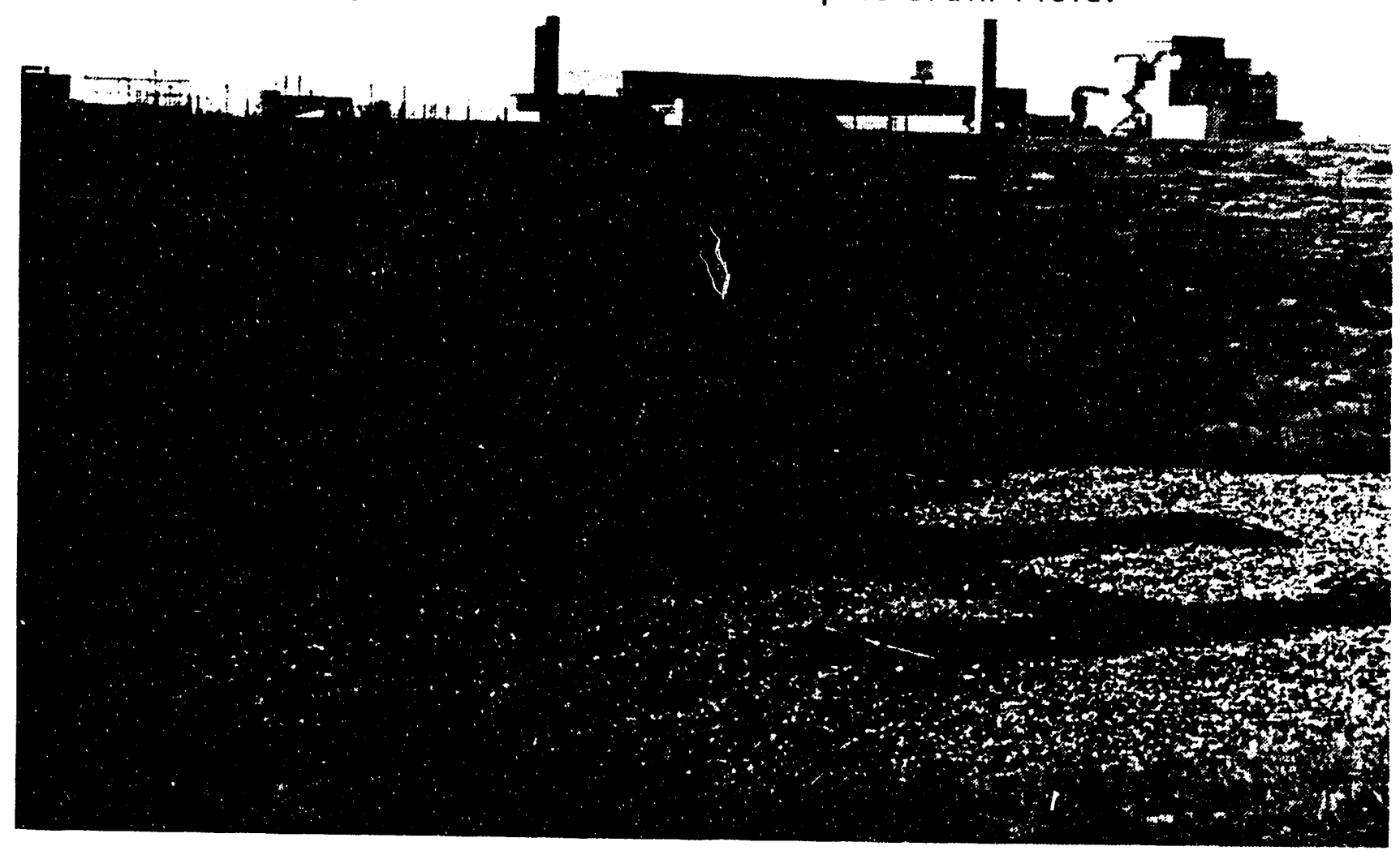

Figure 6-12. Undocumented Septic Tank and Drain Field.

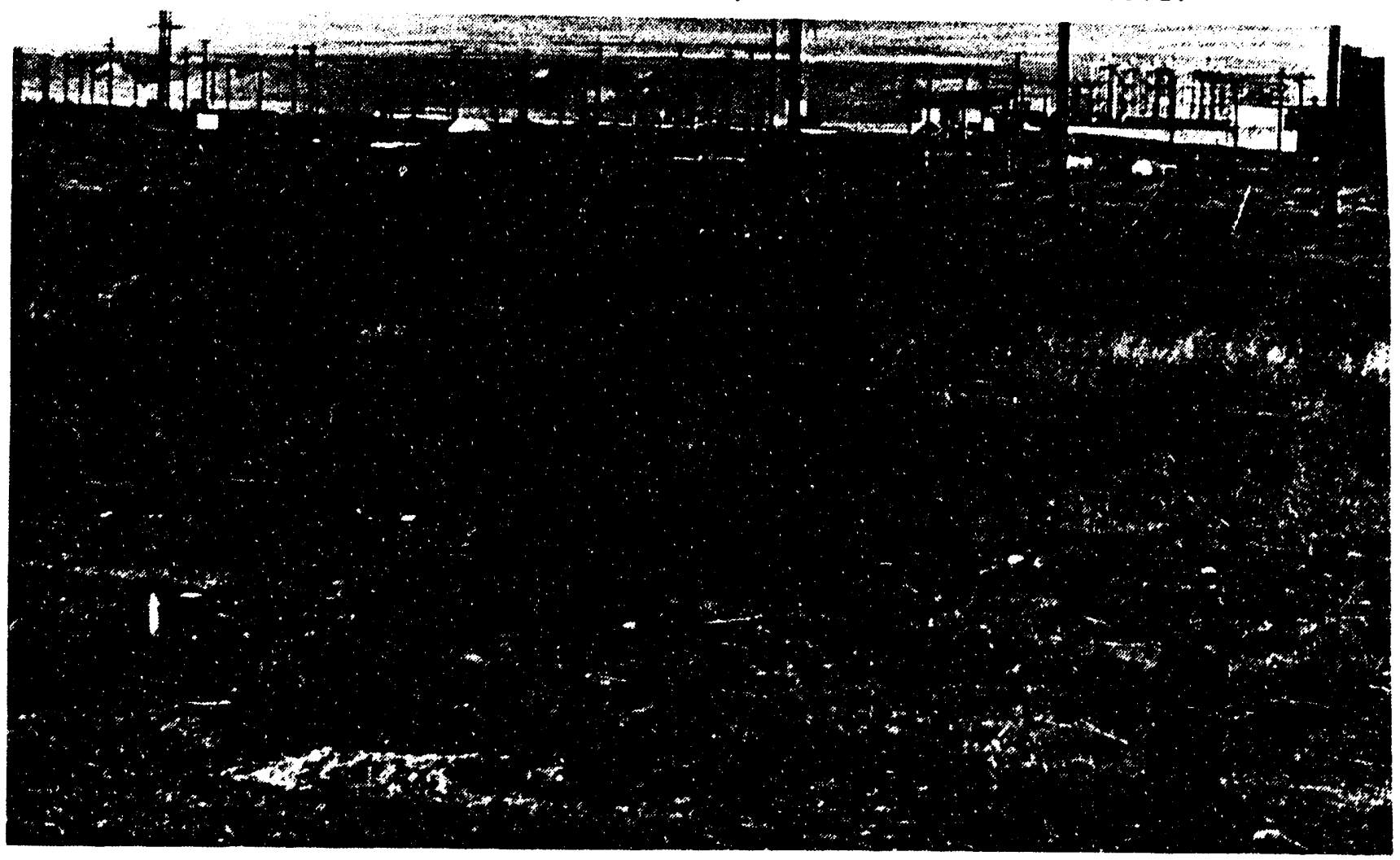




\subsection{UNDOCUMENTED SOLID WASTE BURIAL SITE USED BY MINOR CONSTRUCTION}

Minor Construction burial ground number 6 was a trench dug in the fall of 1956 to be used for the disposal of contaminated equipment removed from the reactor building and effluent system during modification work (Heid 1956). This site was located just outside the perimeter fence and north of the rail spur located just south of 110-D and at the southwest corner of the present solid waste burial site identified as 118-D-4.

\subsection{UNDOCUNENTED SOLID WASTE SITES}

A large barrow pit that was used as a solid waste burial pit was located to the southeast of the 100-DR Reactor facilities and west of the old Patrol Headquarters, at approximate Hanford coordinates N89800 W51000. This site contains backfill and construction debris consisting of concrete rubble, metallic materials, and asphalt material. Site employees report that it was used to dispose of empty cans collected from Army sites located to the northeast of the 100-D Area. These Army wastes would have included 5-gal 0 il cans, cleaning solvent cans, and other miscellaneous solid wastes. A dirt road leading to the site near the railroad tracks has exposed broken floor tile pieces (potential asbestos hazard) at the surface. It is assumed that much of the concrete wastes located here came from demolition of the security and fire station facilities located not far to the east of this waste site (Figure 6-13). The original barrow pit can be seen in the left lower corner of Figure 2-1.

Figure 6-13. 01d Barrow Pit Burial Ground.

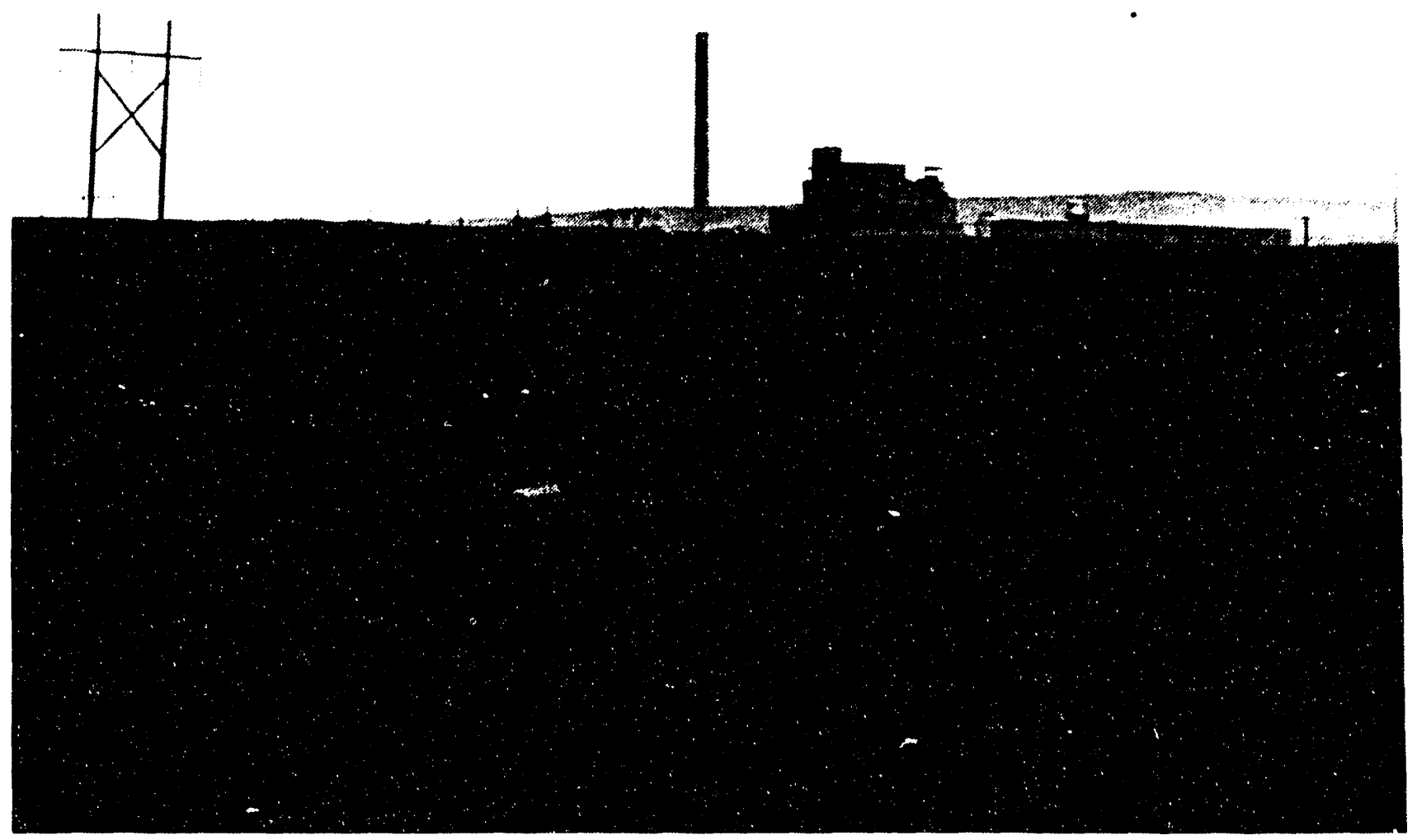


Another barrow pit was excavated to the south and west of the previous site and was also reported to have been used to dispose of solid wastes. This pit is located between the perimeter road and the main access road. There appears to have been dumping of construction debris, concrete and asphalt debris are evident on the surface within the pit. It is reported that construction and demolition wastes were disposed of at the west end of the site where there is evidence of heavy equipment activity. The pit site is posted with a "No Dumping" sign at its the south side entrance (Figure 6-14).

Figure 6-14. Present Barrow Pit and Burial Ground.

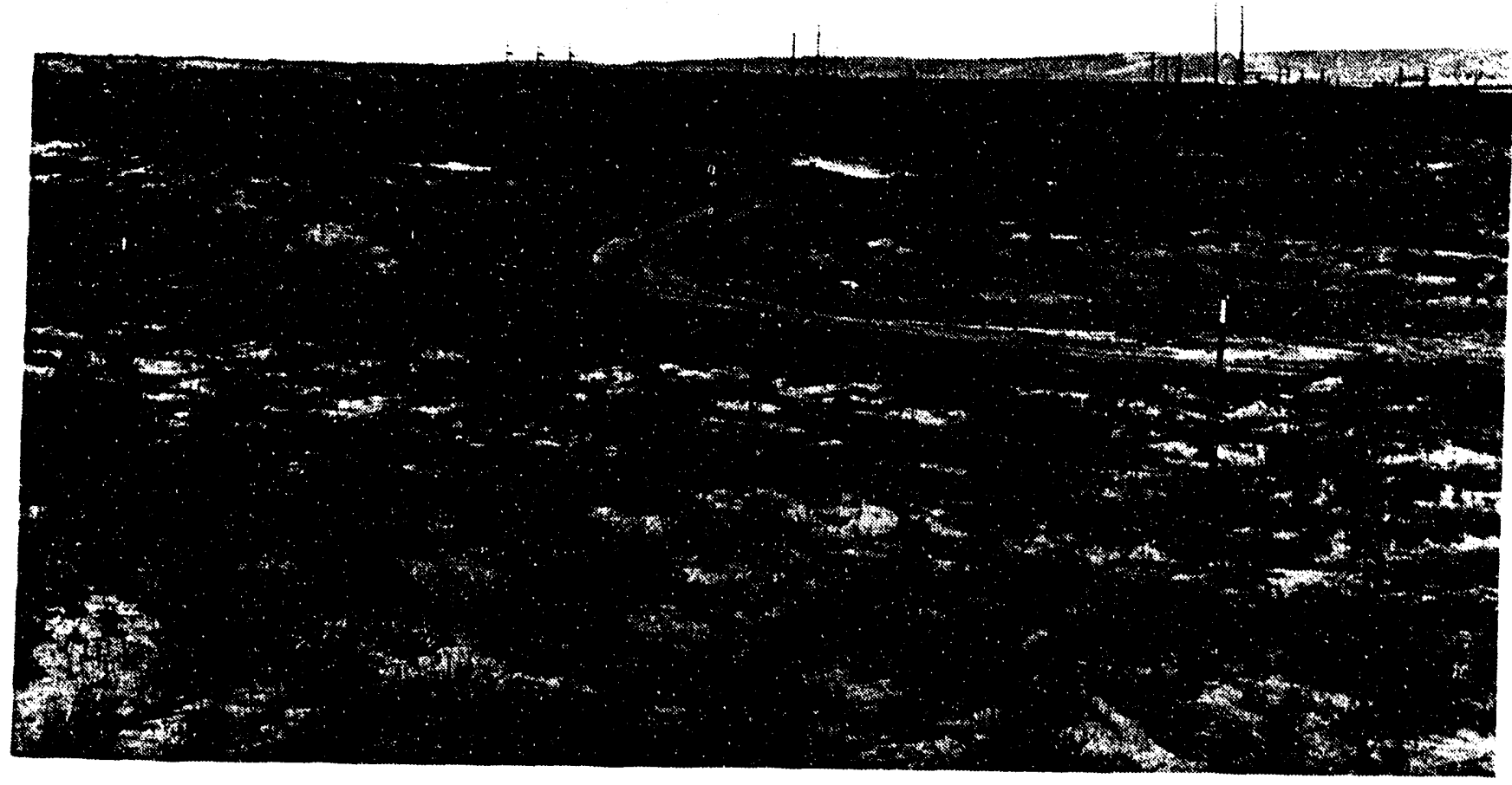

\subsection{UNDOCUMENTED SOLID WASTE SITE, BURN PIT}

A construction burn pit is evident in aerial photographs taken during the construction of the 100-DR Reactor. No evidence of this burn pit remains today and the exact location is uncertain. Photographs taken in August, October, and November 1948 indicate that a large volume of combustible waste was disposed of at this site during the construction of the 100-DR Reactor (Figure 6-15). The entire burn pit has been leveled and graded; natural grasses and vegetation cover the entire area. 
Figure 6-15. Undocumented Burn Pit, 1948.

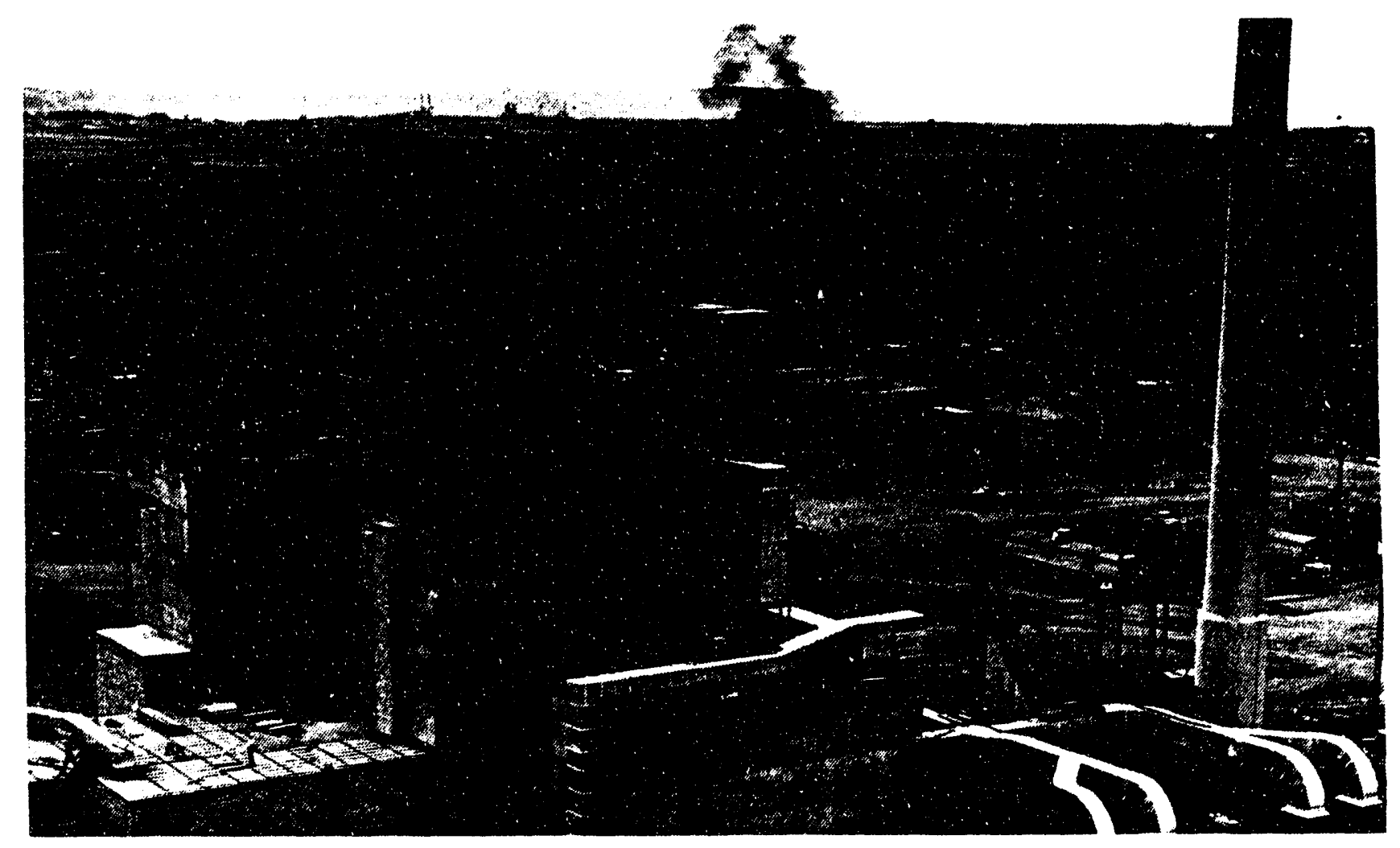

\subsection{0-DR-3 AREA SITE DESCRIPTIONS AND BUILDING DIRECTORY}

Table 6-5 describes facilities and areas not previously mentioned. Some of these facilities may be important from a waste standpoint and have potential for hazardous or radioactive material contamination. Table 6-5 also provides information that may be of use to the reader concerning the known disposition of various sites and facilities. 
WHC-SD-EN-TI-181, Rev. 0

Table 6-5. Facilities.

\begin{tabular}{|c|c|c|}
\hline FACILITY & $\begin{array}{l}\text { HANFORD } \\
\text { LOCATION }\end{array}$ & COMMENTS \\
\hline 108-DR & & $\begin{array}{l}\text { Biology Laboratory. Data found in HW- } 5000 \text {, no additional infor- } \\
\text { mation could be foind to support the existence of this facility, } \\
\text { it is believed that the facility was never constructed. }\end{array}$ \\
\hline $1614-D$ & $\begin{array}{l}N 90310 \\
W 50440 \\
\end{array}$ & $\begin{array}{l}\text { Monitor Station. Figure } 6-16 \text { is the one existing Monitor station } \\
\text { in the 100-D Area and is } 1614-0-3 \text {. }\end{array}$ \\
\hline 1701-D & $\begin{array}{l}\text { N89420 } \\
\text { W50155 } \\
\end{array}$ & Badgehouse \\
\hline $1702-D$ & & $\begin{array}{l}105 \text { Area Badgehouse. Asbestos was removed, the facility was } \\
\text { demoli ished and buried in the } 183-\mathrm{H} \text { clearwelis in } 1990\end{array}$ \\
\hline 1702-DA & & 105-DR Exclusion Area Badge House \\
\hline 1705-D & & $\begin{array}{l}\text { Radio-Botany Laboratory. Data from HW-5000, no additional infor- } \\
\text { mation }\end{array}$ \\
\hline 1709-D & $\begin{array}{l}\text { N89735 } \\
\text { W50585 } \\
\end{array}$ & Fire Headquarters \\
\hline 1713-DR & $\begin{array}{l}N 91150 \\
\text { W52350 } \\
\end{array}$ & Narehouse \\
\hline 1714-DR & $\begin{array}{l}\text { N90450 } \\
\text { W52125 } \\
\end{array}$ & Equipment Storage/Solvent Storage \\
\hline $1720-D$ & $\begin{array}{l}\text { N89595 } \\
\text { W50585 }\end{array}$ & Patrol Headquarters \\
\hline
\end{tabular}

Figure 6-16. 100-D Area Air Monitor Station (Historic Landmark).

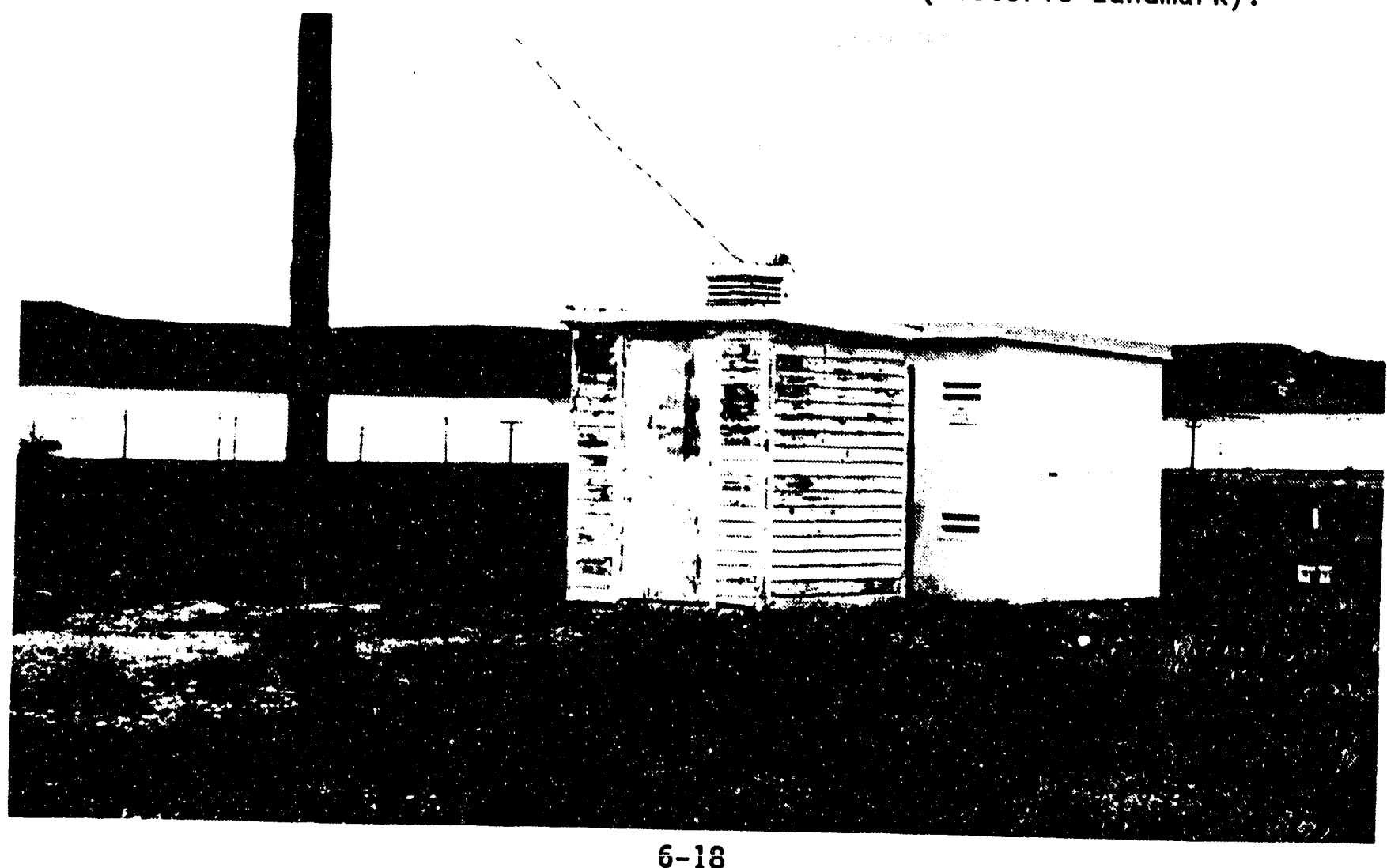




\subsection{REFERENCES}

Beckstrom, JF, 1985, Decommissioning of 105-D Fuel Storage Discharge Ponds, Final Radiological Release Report, TDE-RR-35, United Nuclear Company, Richland, Washington.

Beckstrom, JF, 1987, Decommissioning of 105-DR Fuel Storage Discharge Ponds, Final Radiological Release Report, SD-DD-TI-016, Westinghouse Hanford Company, Richland, Washington.

Chatters, JC, HA Gard, and PE Minthorn, 1992, Fiscal Year 1991 Report on Archaeological Surveys of the 100 Areas, Hanford Site, Washington, PNL8143, Pacific Northwest Laboratory, Richland, Washington.

Clukey, HV, 1954, Tabulation of Radioactive Liquid Waste Disposal Facilities, HW-33305, General Electric Company, Richland, Washington.

Clukey, HV, 1956, Tabulation of Radioactive Liquid Waste Disposal Facilities, $H W-43121$, General Electric Company, Richland, Washington.

Copeland, HC, 1964, Reactor Plant Deactivation General Radiation Investigation, RL-REA-21, General Electric Company, Richland Washington.

Cushing, CE, 1988, Hanford Site National Environmental Policy Act (NEPA), PNL-5415, Rev. 0, Pacific Northwest Laboratory, Richland, Washington.

Cushing, CE, 1991, Hanford Site National Environmental Policy Act (NEPA) Characterization, PNL-6415, Rev. 4, Pacific Northwest Laboratory,
Richland, Washington.

DeNeal, DL, 1965, Historical Events - Single Pass Reactors and Fuels Fabrication, RL-REA-2247, U.S. Department of Energy-Richland Operations
Office, Richland, Washington. DOE, 1988, Registration of Hanford Site Class V Underground Injection Wells,
U.S. Department of Energy

DOE, 1989, Decommissioning of Eight Surplus Production Reactors at the Hanford Site, DOE/EIS - 0119D, United States Department of Energy, Washington D.C.

$\mathrm{DOE} / \mathrm{RL}, 1992 \mathrm{a}$, RCRA Facility Investigation/Corrective Measures Study Work Plan for the 100-HR-3 Operable Unit, DOE/RL-88-36, Rev. 0, U.S. Department of Energy-Richland Operations Office, Richland, Washington. 
WHC-SD-EN-TI-181, Rev. 0

DOE/RL, 1992b, RCRA Facility Investigation/Corrective Measures Study Work Plan for the 100-DR-1 Operable Unit, Hanford Site, Richland, Washington, DOE/RL-89-09, Rev. 0, U.S. Department of Energy-Richland Operations Office, Richland, Washington.

Dorian, JJ and VR Richards, 1978, Radiological Characterization of Retired 100 Areas, UNI-946, United Nuclear Industries, Richland, Washington.

Ecology, EPA, and DOE, 1989 et seq, Hanford Federal Facility Agreement and Consent Order, 2 vols., as amended, Washington State Department of Ecology, U.S. Environmental Protection Agency, U.S. Department of Energy, Olympia, Washington.

Eliason, JR and BF Hajek, 1967, Ground Disposal of Reactor Coolant Effluent, BNWL-CC-1352, Pacific Northwest Laboratories, Richland, Washington,

ERDA, 1975, Waste Management Operations Hanford Reservation, Richland, Washington, ERDA-1538, U.S. Energy Research and Development Administration, Washington, D.C.

Gano, KA and JA Hal1, 1987, Designation Numbers for UNC Controlled Waste Sites in the 100 Areas, UNI-4433, UNC Nuclear Industries, Richland, Washington.

GE, 1952, Design and Construction History, Project C-342 100-DR Water Plant, HW-24800-7, General Electric, Hanford Works, Richland, Washington.

Griffin, PW, 1986, 117-D Filter Building Decommissioning Individual Facility Report, UNI-4040, UNC Nuclear Industries, Richland, Washington.

Griffin, PW, 1987, 115-D/DR Gas Recirculation Facility Decommissioning Individual Facility Report, UNI-4281, United Nuclear Company, Richland, Washington.

Griffin, PW, 1988, 184-B Powerhouse, 184-D Powerhouse and 1717-F Maintenance Shop, Facility Decommissioning Report, SD-DD-TI-033,

Hamilton, MK, 1989, Soil Characterization, memo to RC Roos, CO 14234, Hanford Environmental Health Foundation, Richland, Washington.

Healy, JW, 1951, Radioactivity of Hanford Reactor Cooling Effluent Water, HW-23177-DEL, General Electric Company, Rich1and, Washington.

Heid, KR, 1956, Unconfined Underground Radioactive Waste and Contamination 100 Areas, HW-46715, General Electric Company, Richland, Washington.

Jacques, ID, 1987, UNC Environmental Surveillance Report for the 100 Areas FY 1986, UNI-4065, United Nuclear Industries, Richland, Washington.

Jungfleisch, FM, 1988, Preliminary Evaluation of Hanford Liquid Discharges to Ground, WHC-EP-0052, Westinghouse Hanford Company, Richland, Washington.

Kiser, SK, 1988, Hanford Surplus Facilities Programs Facilities Listings and Descriptions, WHC-SP-0331, Westinghouse Hanford Company, Richland, Washington. 
Miller, RL and RK Wahlen, 1987, Estimates of Solid Waste Buried in 100 Area Burial Grounds, WHC-EP-0087, Westinghouse Hanford Company, Richland, Washington.

Miller, RL and JM Steffes, 1986, Fuel Storage Basins Cleanup and Stabilization Project Report, UNI-3958, United Nuclear Industries, Richland, Washington.

Naiknimbalkar, NM, 1992, Description of Work for 100-D Ponds, Nonintrusive Characterization, WHC-SD-EN-AP-092, Rev. 0, Westinghouse Hanford Company, Richland, Washington.

Newe11, LJ, 1964, Slug Rupture Reports - 1964, HW-80764, General Electric Company, Richland, Washington.

Owen, FE, 1967, Radiological Guide to Deactivation of D-DR Production Facilities, DUN-2447, Douglas United Nuclear, Inc., Richland, Washington,

Parker, HM, 1947, Health Instrument Section Report, Month of September, 1947, HW-7844, General Electric Company, Richland, Washington.

PNL, 1975, Resource Book - Decommissioning of Contaminated Facilities At Hanford, PNL-MA-588, Pacific Northwest Laboratory, Richland, Washington.

PNL, 1991, Resource Book - Decommissioning of Contaminated Facilities at Hanford, PNL-7008, vols. 1-3, Pacific Northwest Laboratory, Richland, Washington.

Roos, RC, 1992, 100-D Ponds: Characterization of Potential Hazardous Waste in the Near Surface Soil and Sediments, WHC-SD-EN-AP-044 Rev. 0, Westinghouse Hanford Company, Richland, Washington.

Roos, RC, 1989, Underground Storage Tank Removal Soil Characterization, Logbook, WHC-N-270, Westinghouse Hanford Company, Richland, Washington.

Ruppert, HG, 1953, Unconfined Underground Radioactive Waste and Contamination, HW-27337, General Electric Company, Richland, Washington.

Schmidt, JW, AR Johnson, SM McKinney, CJ Perkins, CR Webb, 1991, Westinghouse Hanford Company Environmental Surveillance Annual Report, Cr 1991, WHC-EP-0573, Westinghouse Hanford Company, Richland, Washington.

Stenner, RD, KH Cramer, DA Lamar, 1988, Hazard Ranking System Evaluation of CERCLA Inactive Waste Sites at Hanford Volume 1, 2, 3, PNL-6456, Pacific Northwest Laboratory, Richland, Washington.

Tatum, WJ, 1967, Underground Radioactive Materials at 100-D Plant, DUN-3063, Douglas United Nuclear, Richland, Washington.

Trumble, RE, 1956, Hazards Summary Report - Projects CG-558 and CG-600 Reactor Plant Modifications Volume 2, Appendixes, HW-44708 vol. 2, General Electric Company, Richland, Washington. 
WHC-SD-EN-TI-181, Rev. 0

Wahlen, RK, 1991, Summary of the Hanford Site Decontamination, Decommissioning, and Cleanup FY 1974 through FY 1990, WHC-EP-0478, Westinghouse Hanford Company, Richland, Washington.

WHC, 1991, WIDS Database Field Descriptions and Data, WHC-MR-0056 Rev. 1, Westinghouse Hanford Company, Richland, Washington.

WHC, 1992, "ECN-113761," Description of Work for 100-DR-1 Source Operable Unit, WHC-SD-EN-AP-061 Rev. 1, Westinghouse Hanford Company, Richland, Washington.

Winship, RA, 1965, DR-Plant Radiation Zones Final Status Report, RL-REA-1071 


\subsection{BIBLIOGRAPHY}

AEC-GE Study Group, 1964, Catalog of Hanford Buildings and Facilities 100 Areas, TRAC-0375, AEC-GE Study Group for the Economic Development of Richland, Richland, Washington.

DeNeal, DL, 1970, Historical Events - Single Pass Reactors and Fliels Fabrication, DUN-6888, Douglas United Nuclear Company, Richland, Washington.

DOE/RI., 1990, 105-DR Large Sodium Fire Facility Closure Plan, DOE/RL-90-25, iv. O, U.S. Department of Energy-Richland Operations Office, Richland, Washington.

Egge: RG, 1991, Annual Surveillance and Maintenance Report for the Retired Hanford Site Facilities, WHC-EP-0535, Westinghouse Hanford Company, Richland, Washington.

Hamilton, MK, 1989, Water Characterization - 130-D-1 Tank, Hanford Environmental Health Foundation Memo to Roos, RC, Westinghouse Hanford Company, Richland, Washington, November 13, 1989.

HAPO, 1963, Hazards Summary Report Volume 2 Process Control and Technical Data Six 01dest Hanford Production Reactors, vol. 2, HW-74094, Hanford Atomic Products Operation, Richland, Washington.

HAPO, 1967 Official Hanford Atomic Products Operation Building List. Specification Number HW-5000, HW-5000, Hanford Atomic Products Operations, Richl and, Washington.

Herman, DR, 1992, Sampling and Analysis Plan for the 183-D Area Filter Backwash Facility Prccess Wastewater Streams, WHC-SD-WM-PLN-035 Rev. 1, Westinghouse Hanford Company, Richland, Washington.

Kiser, SK, 1984, 100 Deactivated Área Pictorial Review, UNI-2780, United Nuclear Industries, Inc., Richland, Washington.

Miller, L and Steffes (editors), 1987, Radionuclide Inventory and Source Terms for the Surplus Production Reactors at Hanford, UNI-3714 Rev. 1, United Nuclear Industries, Richland, Washington.

Mitchel, THE, and JR Kunk, 1991, 100-DR-l Geophysical Surveys, WHC-MR-0257, Westinghouse Hanford Company, Richlano, Washington.

Operations Support Services Department, 1990, 183-D Filter Backwash Wastewater Stream-Specific Report, WHC-EP-0342 Addendum 33, Westinghouse Hanford Company, Richland, Washington.

Owen, FE, 1966, Special Effluent Sampling and Analysis Program, DUN-1213, Douglas United Nuclear, Richland, Washington. 
Roberts, JW, 1991, Description of Work for the 100-DR-1 Source Operable Unit, WHC-SD-EN-AP-061 Rev. 1, Westinghouse Hanford Company, Richland, Washington.

Selby, JM and JK Soldat, 1958, Summary of Environmental Contamination Inci dents at Hanford 1952-1957, HW-54636, Hanford Atomic Products Operation, Richl and, Washington.

Szulinski, MJ, 1972, Preliminary Problem Definition Decommissioning the Hanford Site, ARH-2164, Atlantic Richfield Hanford, Richland, Washington.

WHC, 1992, Description of Work for 100-D Ponds, Nonintrusive Characterization, WHC-SD-EN-AP-092 Rev. 1, Westinghouse Hanford Company, Richland, Washington. 
WHC-SD-EN-TI-181, Rev. 0

\subsection{HANFORD DRAWINGS REFERENCED IN TEXT}

M-1901-D Sht. 8 Outside Lines Unúerground Water 100-D Area Hanford Works

M-1904-D Shts. 1-8 Outside Lines

H-1-5650 General Layout and Equipment Arrangement Acid Addition Facilities

SK-1-71631 Proposed Location 0il Fired Boiler Installation 100-D Area

H-1-15261 Key Plan and Drawing List Large Scale Sodium Fires Facility

H-1-19823 Civil Plot Plan 117-DR Crib Area

H-1-26426 105-D Bldg. Orainage 1608-D Modifications, Reactor Plant Modifications 
WHC-SD-EN-TI-181, Rev. 0

\section{APPENDIX A}

TABLE OF PHOTOGRAPHS USED 
WHC-SD-EN-TI-181-Rev. 0

This page intentionally left blank

A-2 
WHC-SD-EN-TI-181, Rev. 0

\begin{tabular}{|c|c|c|}
\hline FIG\# & PHOTO NO. & PHOTOGRAPH DESCRIPTION \\
\hline $2-1$ & $6464-11$ & Aerial view, 100-D Area from southeast. Taken 3-1-1962 \\
\hline $2-2$ & & $\begin{array}{l}\text { Aerial view, 100-D from the southeast. Taken shortly after con- } \\
\text { struction, completed pre-1948 }\end{array}$ \\
\hline $2-3$ & 55 & $\begin{array}{l}\text { Aerial view, } 100-0 \text { Area from the southwest. Taken September } 1950 \text {, } \\
\text { near the end of construction of the water treatment facilities for } \\
\text { the DR-Reactor. }\end{array}$ \\
\hline $2-4$ & graphic & Water treatment system, typical \\
\hline $2-5$ & 3705 & $\begin{array}{l}\text { Aerial view, 100-D Area from the north. Taken March } 1956 \text {, near the } \\
\text { completion of the } 1904-0 R \text { outfall pipel ine. Sondensate and efflu- } \\
\text { ent water from the } 1904-0 \text { outfall line can be seen vent ing on the } \\
\text { west end of the island that the pipel ines pass through }\end{array}$ \\
\hline $2-6$ & $1752 \# 37$ & 107-DR retention basin. Taken in 1948. Shows bas in construction \\
\hline $2-7$ & $85 \mathrm{H} 807-4 \mathrm{cn}$ & 105-D fuel storage basin \\
\hline $2-8$ & $846707-12 \mathrm{cn}$ & 105-D fuel storage basin during cleanout \\
\hline $2-9$ & G-132-465 & Typical confinement facility layout \\
\hline 4-1 & 3428 & 100-D CG-558. Taken July 27, 1955 \\
\hline $4-2$ & $93040093-28 \mathrm{cn}$ & $\begin{array}{l}\text { 116-D-1A. Taken March 1993. Wood structure in the background } \\
\text { housed gasol ine generator for emergency power }\end{array}$ \\
\hline $4-3$ & $93040093-27 \mathrm{cn}$ & $\begin{array}{l}\text { 116-D-18, from the northeast corner. Taken March } 1993.100-0 \\
\text { Reactor is in the background }\end{array}$ \\
\hline $4-4$ & $93041615-7 \mathrm{cn}$ & $\begin{array}{l}\text { Possible location of the } 116-0-2 \text { pluto crib. Taken March } 1993 \text {, } \\
\text { from the south. 103-D and Generator Building are in the background }\end{array}$ \\
\hline $4-5$ & $93041616-2 \mathrm{cn}$ & Possible pluto crib location $* 2$. 105-D in background \\
\hline $4-6$ & $93041615-3 \mathrm{cn}$ & Possible pluto crib location $\$ 3$. 105-D in background \\
\hline $4-7$ & $93041451-20 \mathrm{cn}$ & 108-0 french drain 1 \\
\hline $4-8$ & $93041615-21 \mathrm{cn}$ & 108-0 french drain $* 2$ \\
\hline $4-9$ & $\mathrm{P}-7293$ & 1904-D out fall. Taken in 1944 \\
\hline $4-10$ & $93040093-22 \mathrm{cn}$ & $\begin{array}{l}116-D-5,1904-D \text { out foll structure, from the southeast corner. } \\
\text { Iaken March 1992. The } 1956 \text { expansion on the south side is apparent }\end{array}$ \\
\hline $4-11$ & $93040093-20 \mathrm{cn}$ & $\begin{array}{l}\text { 116-D-5, 1904-D outfall flume from the south riverbank. Taken } \\
\text { March } 1993 \text {. }\end{array}$ \\
\hline $4-12$ & $93041615-11 \mathrm{cn}$ & 105-D cushion corridor french drain \\
\hline $4-13$ & P-6141 & $\begin{array}{l}\text { 100-D Area. Taken Septenber 25, 1944. Retention bas in compart- } \\
\text { ments apparent in background }\end{array}$ \\
\hline $4-14$ & $93040093-23 \mathrm{cn}$ & $\begin{array}{l}\text { 116-0-7, 107-0 reterition basin from the northeast corner. Taken } \\
\text { March 1993. The exposed effluent line is visible ot the middle } \\
\text { left }\end{array}$ \\
\hline $4-15$ & $93040093-30 \mathrm{cn}$ & $\begin{array}{l}116-0-9,117-0 \text { seal pit crib from the southeast corner. Taken } \\
\text { March } 1993 \text {. The } 105-0 \text { Reactor is in the background }\end{array}$ \\
\hline
\end{tabular}


WHC-SD-EN-TI-181, Rev. 0

\begin{tabular}{|c|c|c|}
\hline $4-16$ & $93041615-20 \mathrm{~cm}$ & 100-D fuel storage bas in cleanout ponds \\
\hline $4-17$ & $93040093-13 \mathrm{cn}$ & $\begin{array}{l}\text { 116-DR-1 and 116-DR-2, } 107-D R \text { liquid disposal trenches from the } \\
\text { northeast with 100-D Facilities in the background }\end{array}$ \\
\hline $4-18$ & 3667 & $\begin{array}{l}\text { 116-DR-5, } 1904-D R \text { outfall. Taken in } 1956 \text { showing construction of } \\
\text { the outfall and excavation of the island for the Effluent Pipe } \\
\text { installation }\end{array}$ \\
\hline $4-19$ & $93040093-19 \mathrm{cn}$ & $\begin{array}{l}\text { 116-DR-5, 1904-DR outfall. Taken March 1993. There is a manhole } \\
\text { at the mid left of the photo that indicates an underlying large } \\
\text { void when tapped on }\end{array}$ \\
\hline $4-20$ & $93040093-18 \mathrm{cn}$ & 116-DR-5, 1904-DR outfall flume. Taken March 1993 \\
\hline 4-21 & $1735-20$ & 107-DR retention bas in construction \\
\hline $4-22$ & $1736-21$ & 107-DR retention bas in construction \\
\hline $4-23$ & $93040093-14 \mathrm{cn}$ & $\begin{array}{l}\text { 116-DR-9, 107-DR retention basin from the northeast corner. Taken } \\
\text { March } 1993 \text {. Both 100-D Area Reactors are visible in the background }\end{array}$ \\
\hline 4-24 & $93041451-18 c n$ & 105-D \\
\hline $4-25$ & $93040093-24 \mathrm{cn}$ & $\begin{array}{l}\text { 120-D-1, 100-D Area ponds from the northeast corner. Taken March } \\
1993 \text {. The inlet is the concrete structure in the middle left of } \\
\text { the photo. The two steel overflow pipes ore visible. The original } \\
\text { corrugated steel overflow pipe is visible in the bottom left of the } \\
\text { photo. } 100-0 \text { is in the background }\end{array}$ \\
\hline 4-26 & $93041451-1 c n$ & 186. 0 waste acid basin \\
\hline 4-27 & $93041616-22 \mathrm{cn}$ & 100-D Area ash disposal basin orphan 55-gal drum \\
\hline 4-28 & 2188 & 100-D Area to illustrate size of coal pit \\
\hline 4-29 & $106669-59 \mathrm{cn}$ & 184-D coal pit. Taken in 1969, then being used os a burial ground \\
\hline $4-30$ & $93041451-9 \mathrm{cn}$ & 184-D coal pit today \\
\hline $4-31$ & $93041615-17 \mathrm{cn}$ & Salt and brine pit, 100-D Area \\
\hline $4-32$ & $93041615-15 \mathrm{cn}$ & Subsidence near salt/brine pit, 100-D Area \\
\hline $4-33$ & $93040093-12 \mathrm{cn}$ & $\begin{array}{l}\text { 128-D-2, burn pit from the east side. Taken March } 1993 \text {. Demoli- } \\
\text { tion debris are seen in the forreground. The burn pit itself } \\
\text { appeared to be located very near the large pile of tumbleweeds in } \\
\text { the background (right side of the photo). The top of the 100-D } \\
\text { Reactor and exhaust stack are visible in the background }\end{array}$ \\
\hline $4-34$ & $93041615-14 \mathrm{cn}$ & 100-D gasoline tank site \\
\hline $4-35$ & 2038 & $\begin{array}{l}\text { 6-8-53 100-D Area. Shows septic tank in lower left corner with } \\
\text { white fence around it }\end{array}$ \\
\hline 4-36 & $93041615-4 \mathrm{cn}$ & 115-0/DR Gas Recirculation Facility \\
\hline $4-37$ & $93041615-5 \mathrm{cn}$ & 117-0 Confinement Air filter facility \\
\hline 4-38 & $93041615-6 \mathrm{cn}$ & 1608-D Facility \\
\hline 4-39 & $93041615-26 \mathrm{cn}$ & 628-3 suspect site \\
\hline $4-40$ & $93041615-29 \mathrm{cn}$ & East of 100-D Area near 628-3 farm dump \\
\hline
\end{tabular}


WHC-SD-EN-TI-181, Rev. 0

\begin{tabular}{|c|c|c|}
\hline $4-41$ & $93040093-25 \mathrm{cn}$ & $\begin{array}{l}\text { 1607-D2, septic tank from the northeast. Taken March } 1993 \text {. Lies } \\
\text { within a surface contamination area between the } 107 \text { retention } \\
\text { basins. } 100-0 \text { Facilities are in the background }\end{array}$ \\
\hline $4-42$ & $93040093-15 \mathrm{cn}$ & $\begin{array}{l}\text { 1607-02, septic drain field from the southwest corner. Taken March } \\
1993 \text {. Vent pipes can be seen in the middle left of the photo. The } \\
\text { sign in the foreground reads "Danger Do Not Enter Authorized } \\
\text { Personnel Only" }\end{array}$ \\
\hline $4-43$ & $93041451-6 \mathrm{cn}$ & Septic system at 181-D \\
\hline $4-44$ & $93050354-2 \mathrm{cn}$ & Suspect septic system manhole, north of 100-0 \\
\hline $4-45$ & $93041615-12 \mathrm{cn}$ & $\begin{array}{l}\text { Suspect solid waste burial site from the east side. Taken March } \\
1993 \text {. Is shown as the chained-off area in the foreground. 103-0 } \\
\text { building is in the background }\end{array}$ \\
\hline $4-46$ & graphic & Map taken from Heid 1956 and redrawn for clarity \\
\hline $4-47$ & graphic & Hanford Drawing H-1-4046 \\
\hline $4-48$ & $93040093-34 \mathrm{cn}$ & VSR burial ground \\
\hline $4-49$ & $93040093-35 \mathrm{cn}$ & $\begin{array}{l}\text { Undocumented solid waste site outside burial ground markers, site } \\
\# 18\end{array}$ \\
\hline $4-50$ & $93041615-25 \mathrm{cn}$ & Suspect solid waste site east of 100-D Area \\
\hline $4-51$ & $93041615-24 \mathrm{cn}$ & Suspect solid waste site east of 100-D Area \\
\hline $4-52$ & $83795-11 \mathrm{cn}$ & 1907-DR outfall before demolition \\
\hline $4-53$ & $93040723-27 \mathrm{cn}$ & 1907-DR outfall today \\
\hline $4-54$ & $93050354-1 \mathrm{cn}$ & Suspect liquid waste site storm drain near the 1904 outfalls \\
\hline $4-55$ & $93041615-32 \mathrm{cn}$ & Lead sheet cover on concrete pad south of 186-D Building site \\
\hline $4-56$ & $93041451-\mathrm{cn}$ & oil-conteminated soil east of $190-0$ \\
\hline 4-57 & $93041615-35 \mathrm{cn}$ & Subsidence near the 189-D storage pad \\
\hline $4-58$ & $93041615-34 \mathrm{cn}$ & Detail of Figure $4-57$ \\
\hline $4-59$ & $93041451-7 \mathrm{cn}$ & Filter backwash trench \\
\hline $4-60$ & $93040723-25 \mathrm{cn}$ & Flume upstrean of the 181-0 pumphouse \\
\hline $4-61$ & $93040723-26 \mathrm{cn}$ & Pipe in flume upstrean of the 181-D pumphouse \\
\hline $4-62$ & $93050354-6 \mathrm{cn}$ & Acid tank crodles and drain trench near $182-D$ \\
\hline $5-1$ & 1065 & Cask pod, suspect french drain oddition. Taken December 21, 1949 \\
\hline $5-2$ & $93041451-15 \mathrm{cn}$ & 100-D Cask pad \\
\hline $5-3$ & $93040723-14 \mathrm{cn}$ & 105-DR fuel storage bas in trench \\
\hline $5-4$ & $93040723-11 \mathrm{cn}$ & 105-DR pluto crib \\
\hline $5-5$ & $93040723-2 \mathrm{cn}$ & 1608-DR effluent trench \\
\hline
\end{tabular}


WHC-SD-EN-TI-181, Rev. 0

\begin{tabular}{|c|c|c|}
\hline $5-6$ & $93040723-12 \mathrm{cn}$ & 105-DR ink well crib (tank) \\
\hline $5-7$ & $93040723-17 \mathrm{cn}$ & 117-DR crib (116-DR-8) \\
\hline 5-8 & $93041451-12 \mathrm{cn}$ & VSR thimble burial ground south of 105-DR \\
\hline $5-9$ & 4024 & 105-DR fuel storage basin leakage \\
\hline $5-10$ & $93041451-17 \mathrm{cn}$ & $105-D R$ \\
\hline $5-11$ & $93040093-7 \mathrm{cn}$ & French drain near the Sodium fire Facility water filter \\
\hline $5-12$ & $93041451-13 \mathrm{cn}$ & Sodium fire facilities \\
\hline $5-13$ & $106669-58 \mathrm{cn}$ & 190-DR tankwell pit burial ground \\
\hline $5-14$ & $93041451-4 c n$ & $\begin{array}{l}\text { Asbestos Contamination Area in the 190-DR tankwell pit burial } \\
\text { ground }\end{array}$ \\
\hline $5-15$ & $93041615-1 \mathrm{cn}$ & 1608-DR facility site \\
\hline $5-16$ & $93041451-16 \mathrm{cn}$ & 151-D septic tank and drain field \\
\hline $5-17$ & $93041451-2 c n$ & Sodium Dichromate Pumping Station \\
\hline $6-1$ & $93041615-18 \mathrm{cn}$ & 105-DR fuel storage basin cleanout pond \\
\hline $6-2$ & $93040723-18 \mathrm{cn}$ & 100-D Area burial ground number 1 \\
\hline $6-3$ & $93040723-22 \mathrm{cn}$ & 100-D Area burial ground number 2 \\
\hline $6-4$ & $93050354-3 \mathrm{cn}$ & $\begin{array}{l}\text { Suspect liquid waste site, repair of the "11 west effluent line. } \\
100-0 R \text { in back ground. Mound in foreground is expansion box }\end{array}$ \\
\hline $6-5$ & $93040723-1 \mathrm{cn}$ & 118-D-3 burial ground, 100-DR in background \\
\hline $6-6$ & $93040093-36 \mathrm{cn}$ & 118-D-4 burial ground, 100-D in background \\
\hline $6-7$ & $93041451-11 \mathrm{cn}$ & 100-DR gas loop burial ground \\
\hline $6-8$ & $93041615-30 \mathrm{cn}$ & $\begin{array}{l}\text { Suspect location of the 128-D-1 burn pit. Transite siding pieces } \\
\text { can be seen in the foreground }\end{array}$ \\
\hline $6-9$ & 2039 & $\begin{array}{l}\text { 100-D Area Patrol and Fire Station. Taken June } 8,1953 \text {. Septic } \\
\text { system can be seen in the lower left portion of the photograph }\end{array}$ \\
\hline $6-10$ & $93040723-15 \mathrm{cn}$ & Undocumented septic tank (IMHOFF tank). 100-DR in background \\
\hline $6-11$ & $93040723-16 \mathrm{cn}$ & Undocumented septic drain field attached to the IMHOFF tank \\
\hline $6-12$ & $93040723-20 \mathrm{cn}$ & $\begin{array}{l}\text { Undocumented septic tank and drain field south of 100-DR and the } \\
\text { old perimeter road }\end{array}$ \\
\hline $6-13$ & $93050354-4 \mathrm{cn}$ & Old barrow pit burial ground south east of 100-DR \\
\hline $6-14$ & $93050354-5 \mathrm{cn}$ & $\begin{array}{l}\text { Present barrow pit and burial ground south of } 100-D R \text { across the } \\
\text { perimeter road from the old berrow pit }\end{array}$ \\
\hline $6-15$ & 901 & 08-26-1948 undocumented burn pit southeast of 100-DR \\
\hline $6-16$ & $93041615-31 \mathrm{cn}$ & 100-D Area Air Monitor Station (historic landmark) \\
\hline
\end{tabular}


WHC-SD-EN-TI-181, Rev. 0

\section{APPENDIX B}

\section{MAPS}


WHC-SD-EN-TI-181-Rev.0

This page intentionally left blank 


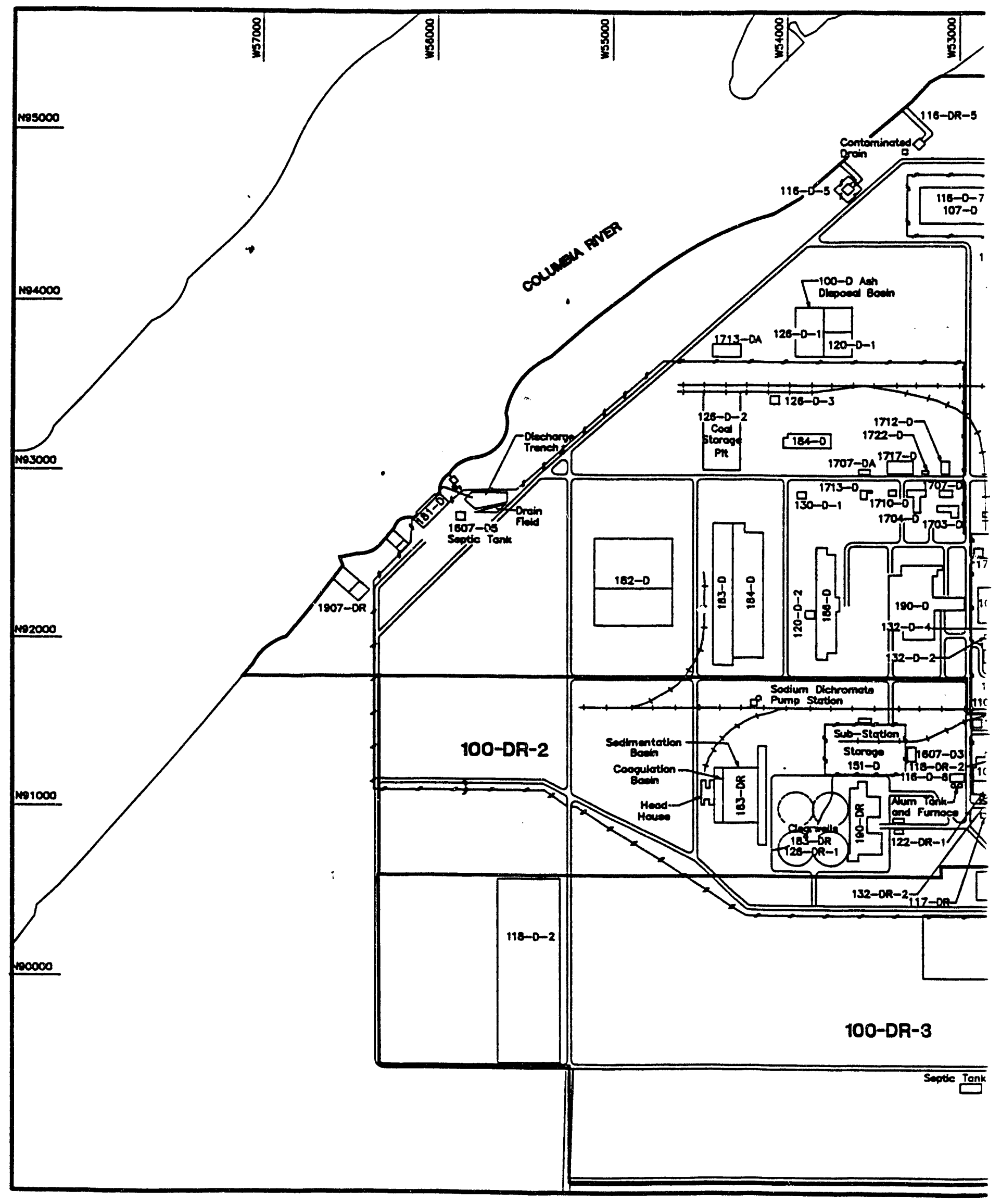




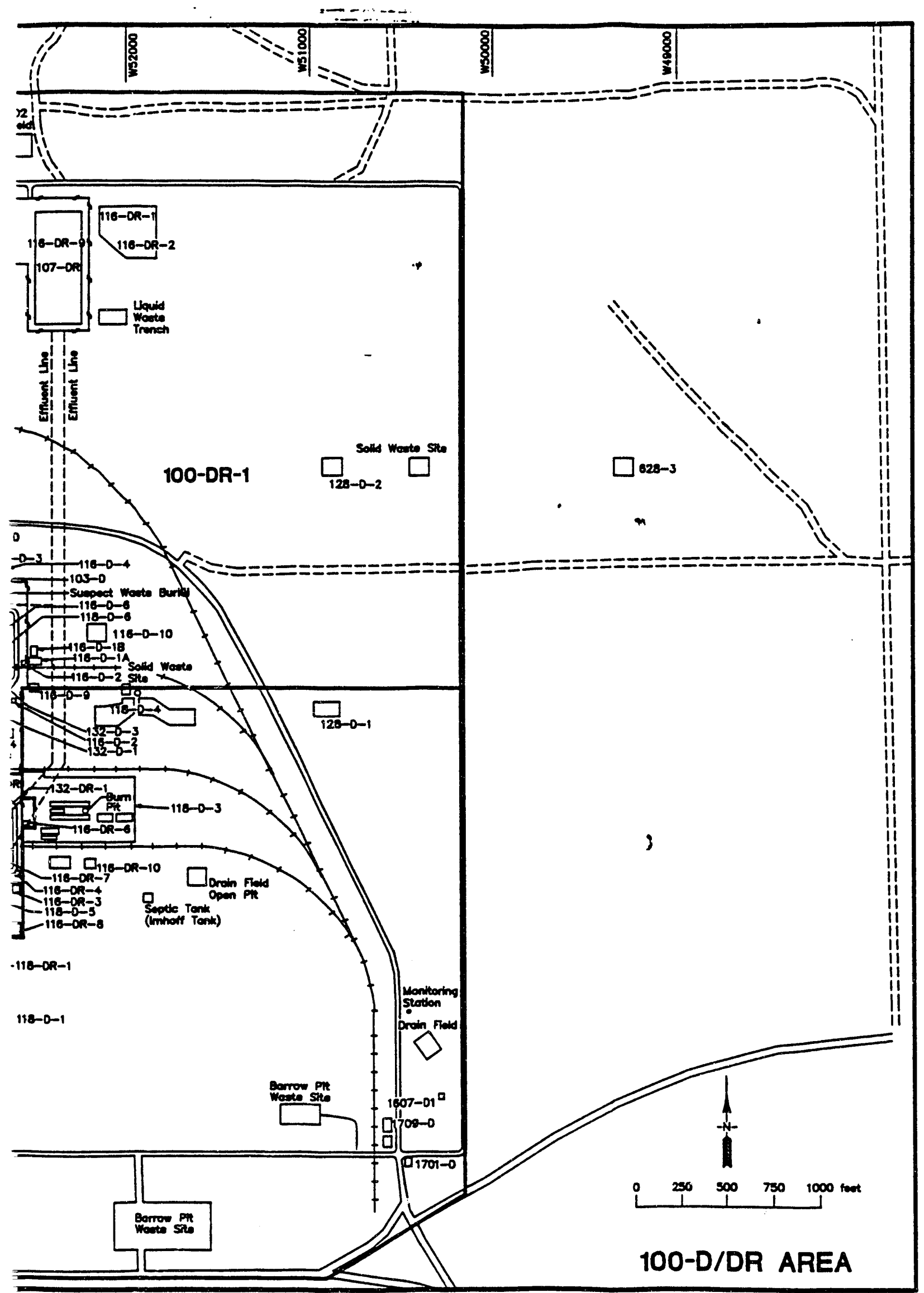

441041523-8 


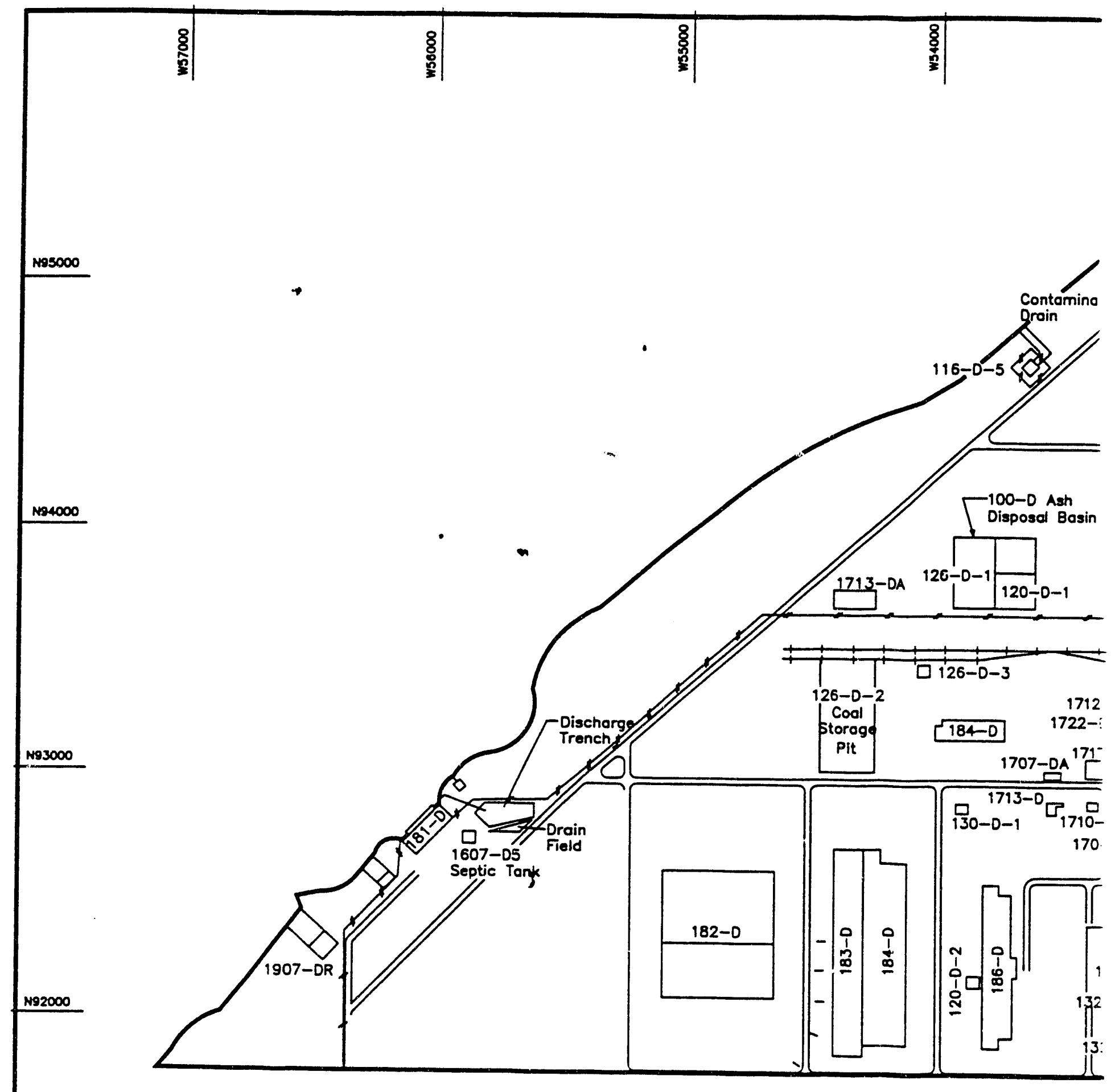



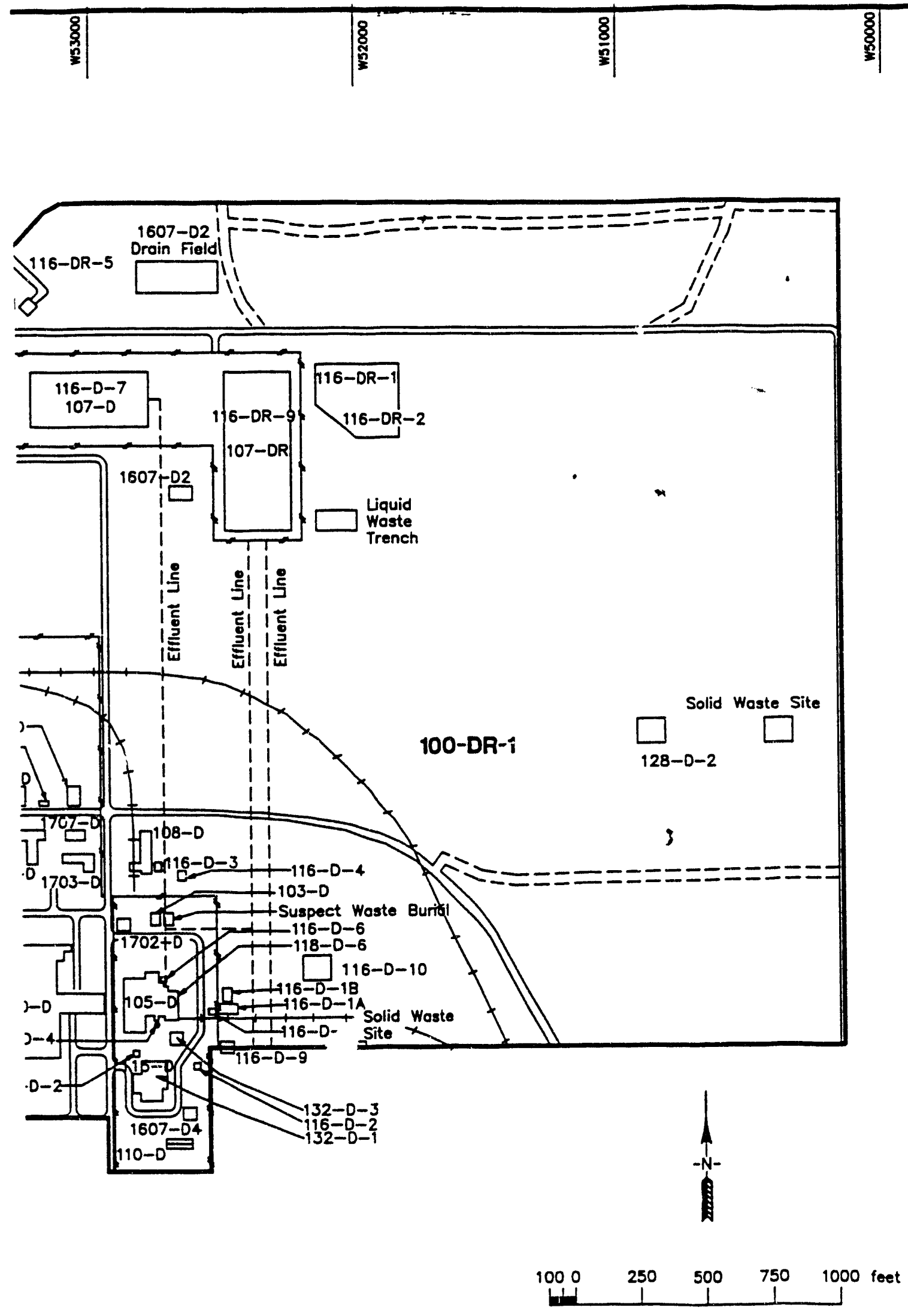


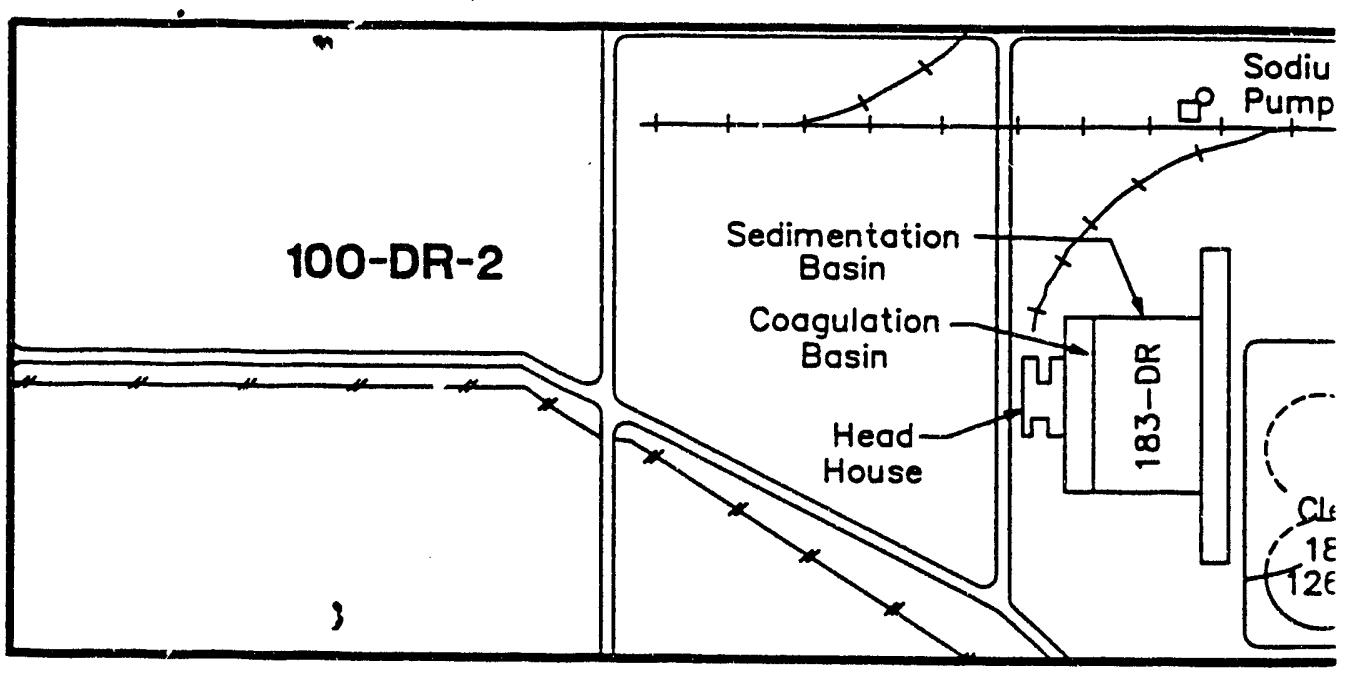

N90000 


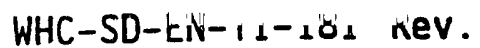

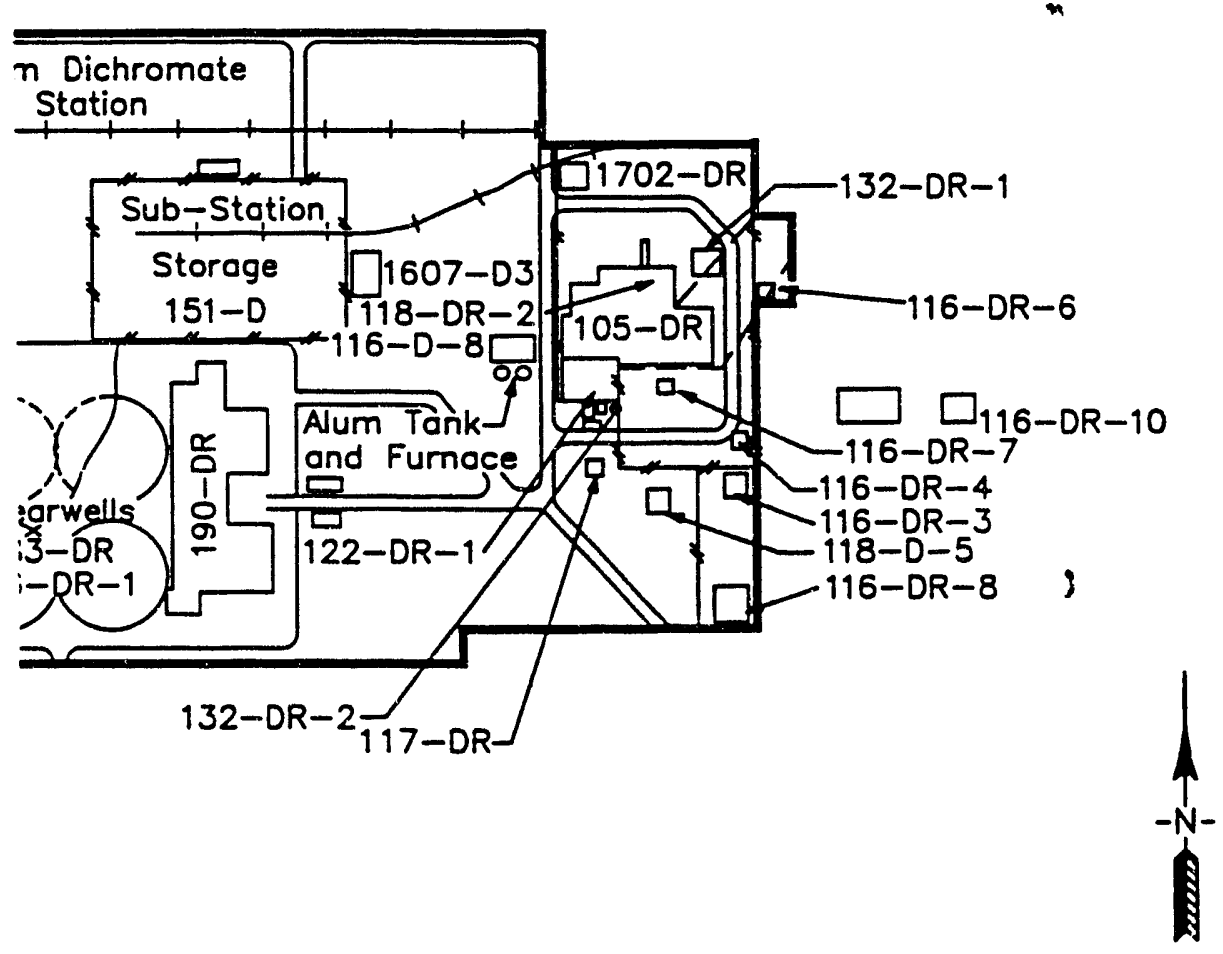

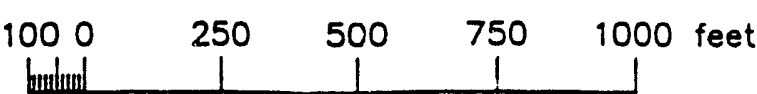

응

్ㅗㅀ 


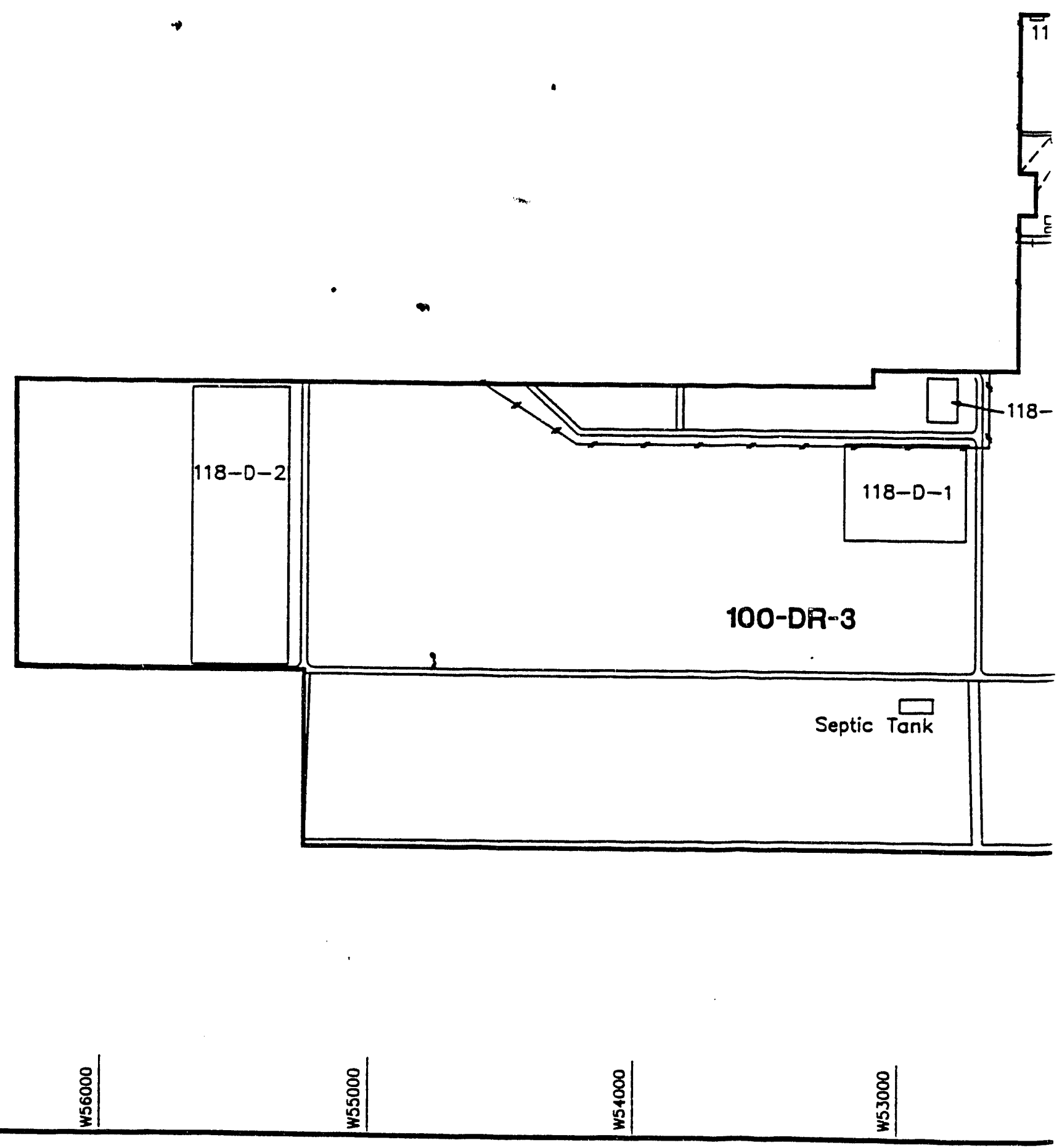




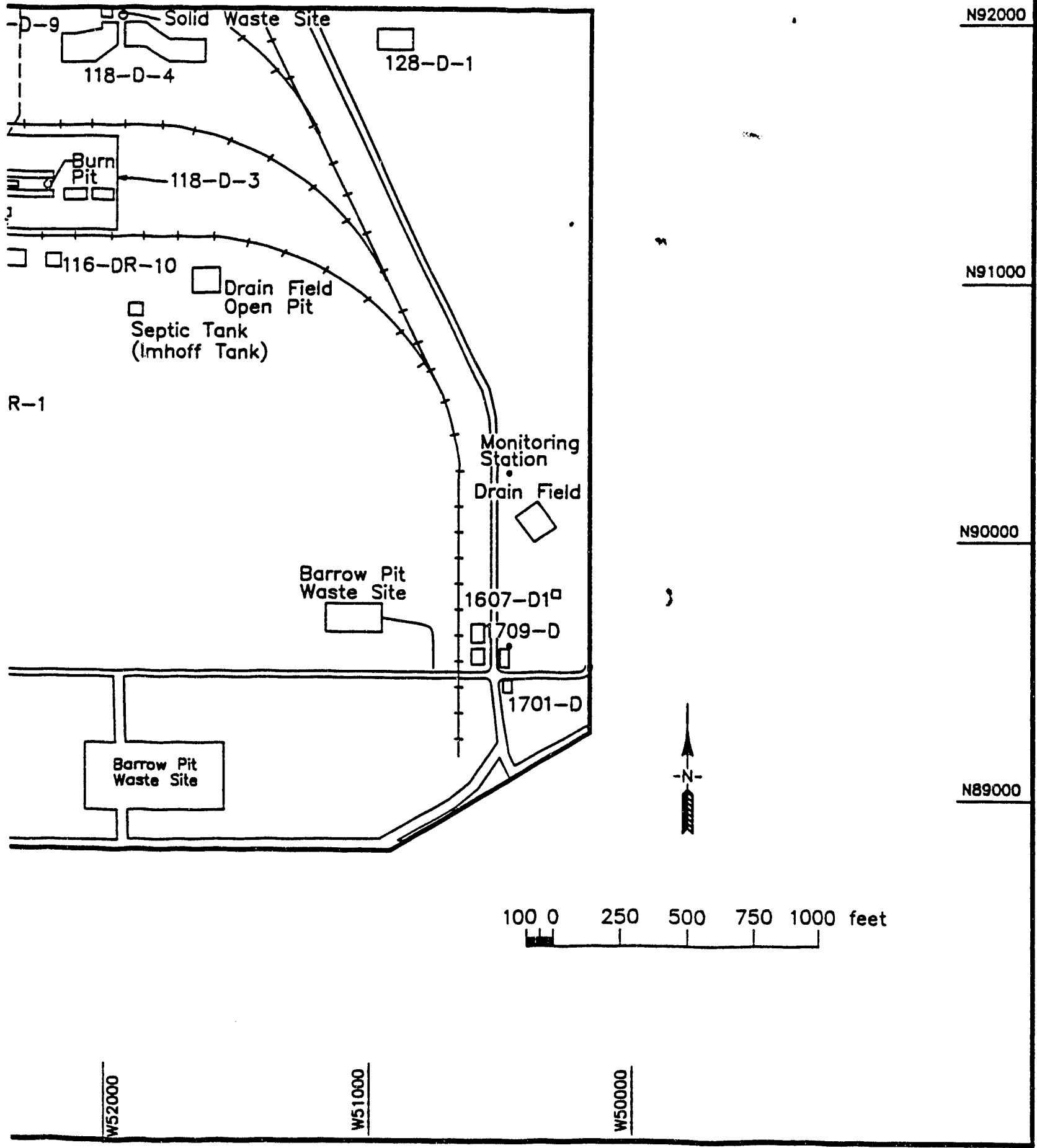




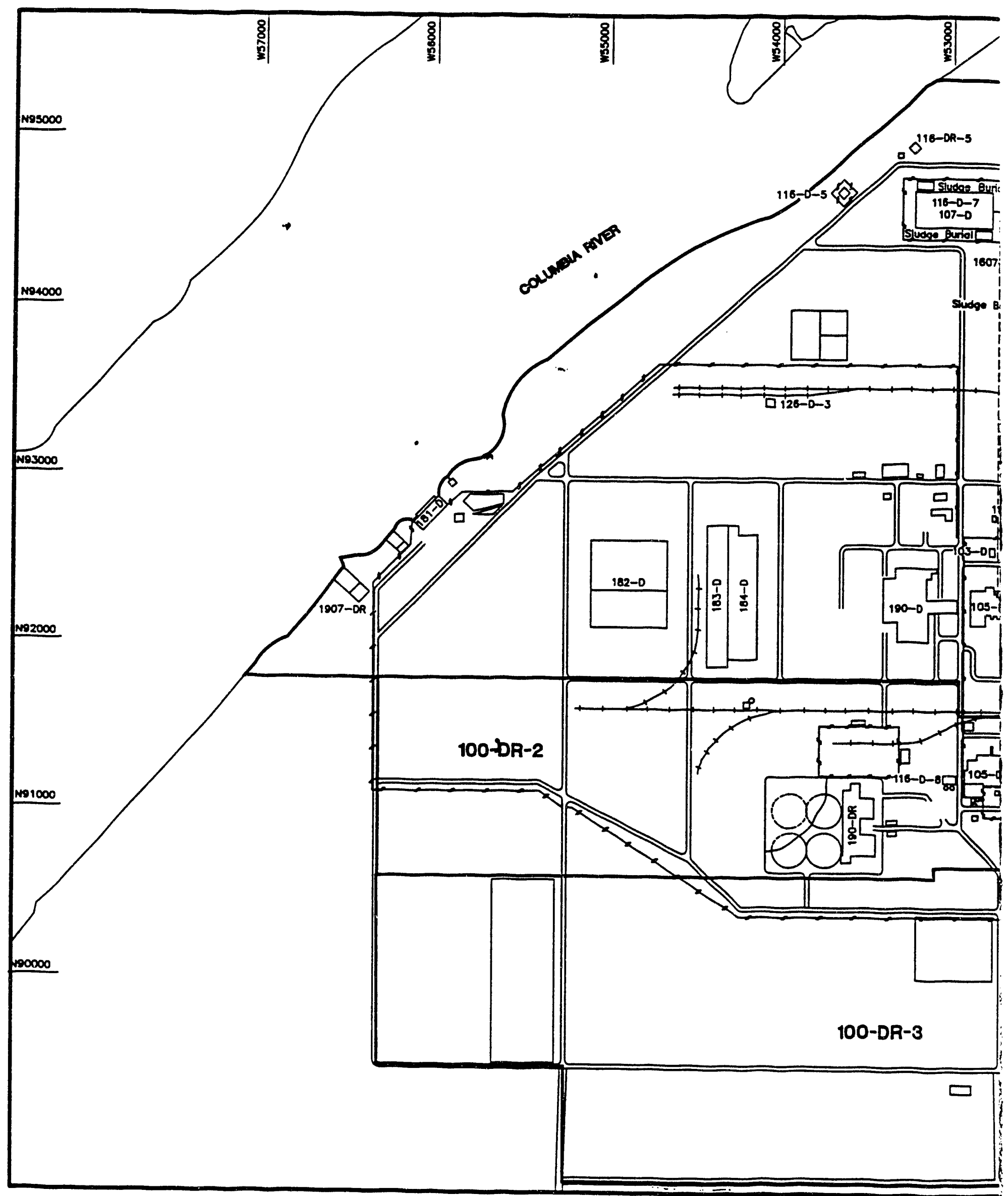




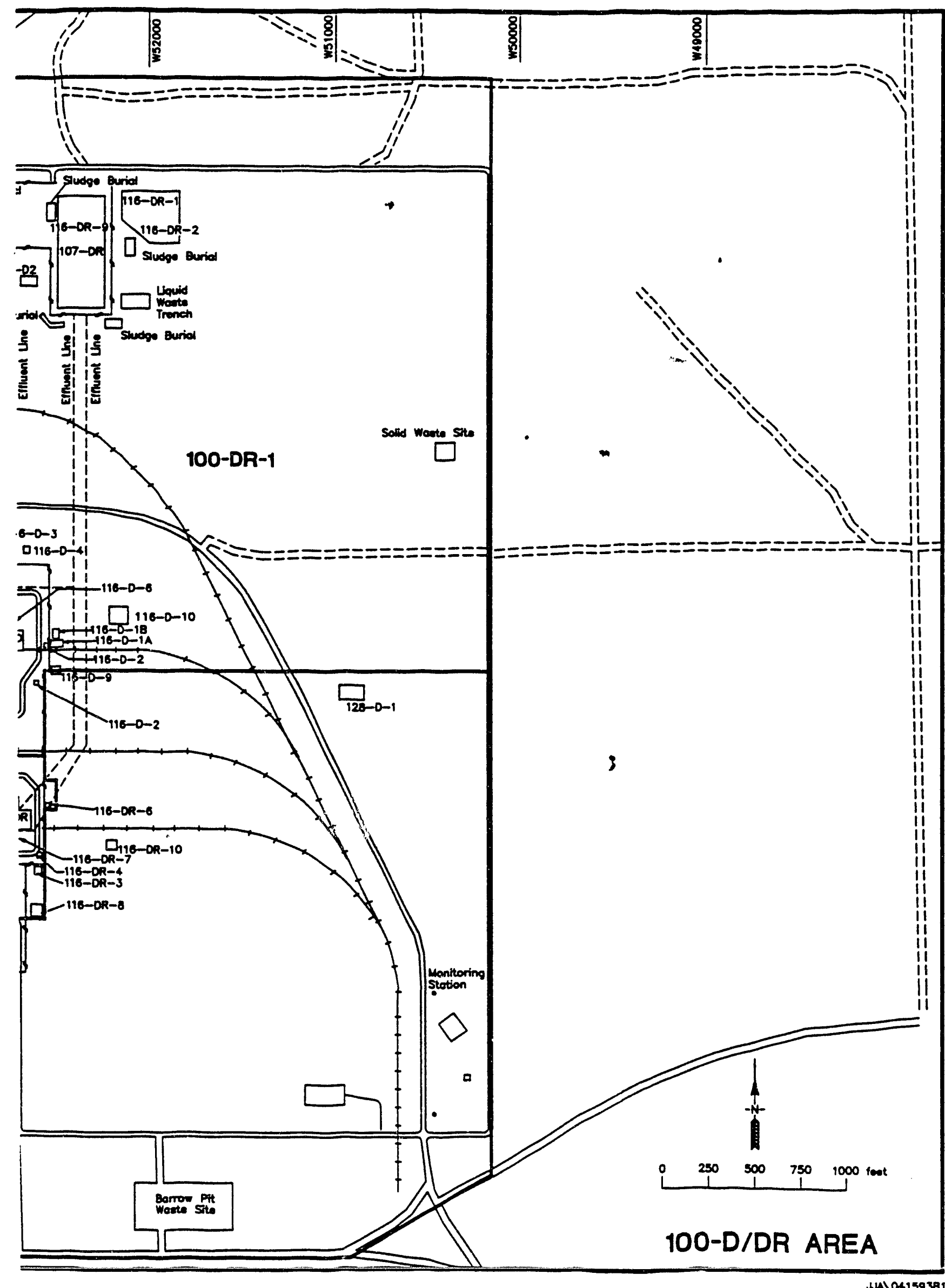




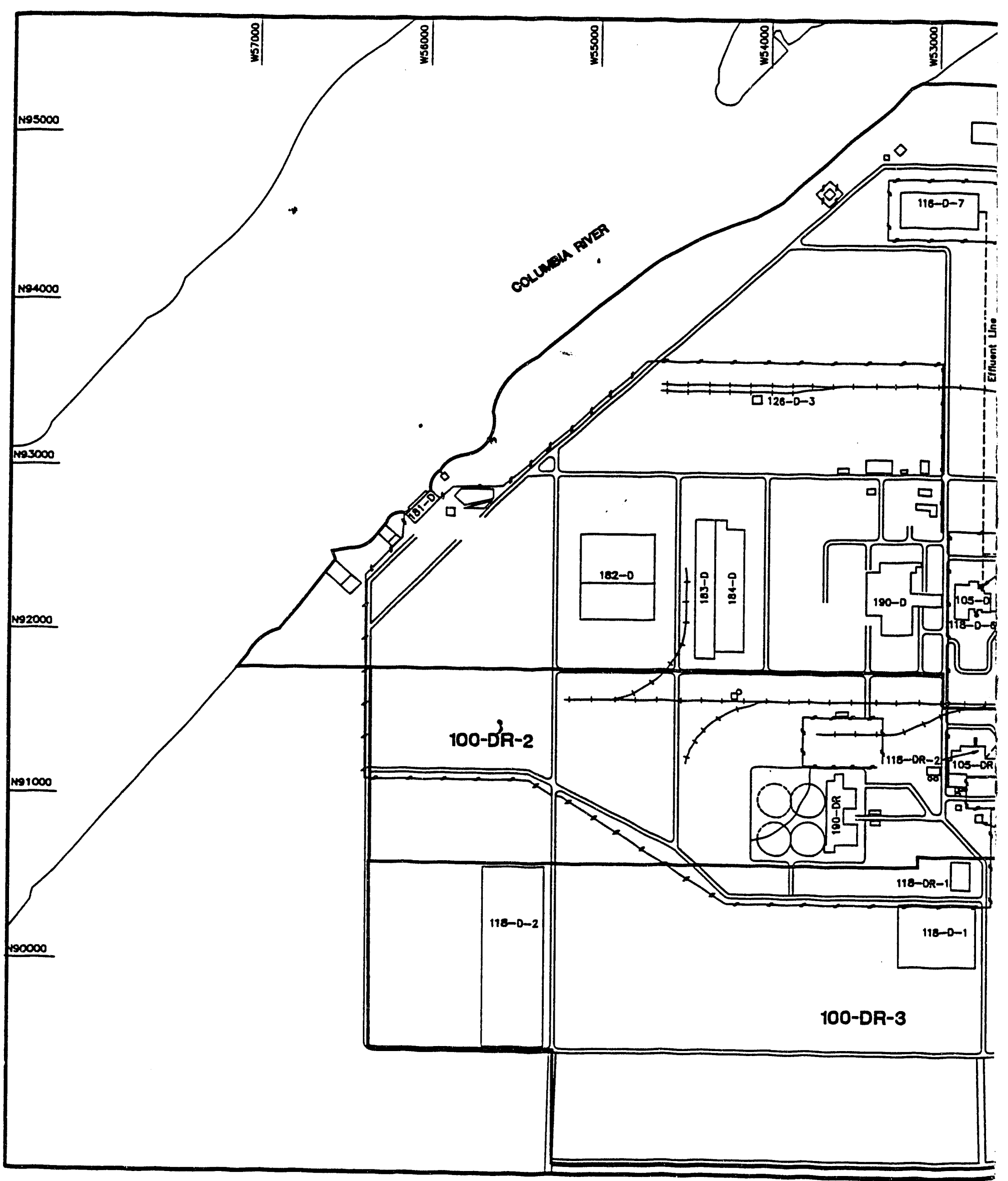


WHC-SD-EN-TI-181 Rev. 0

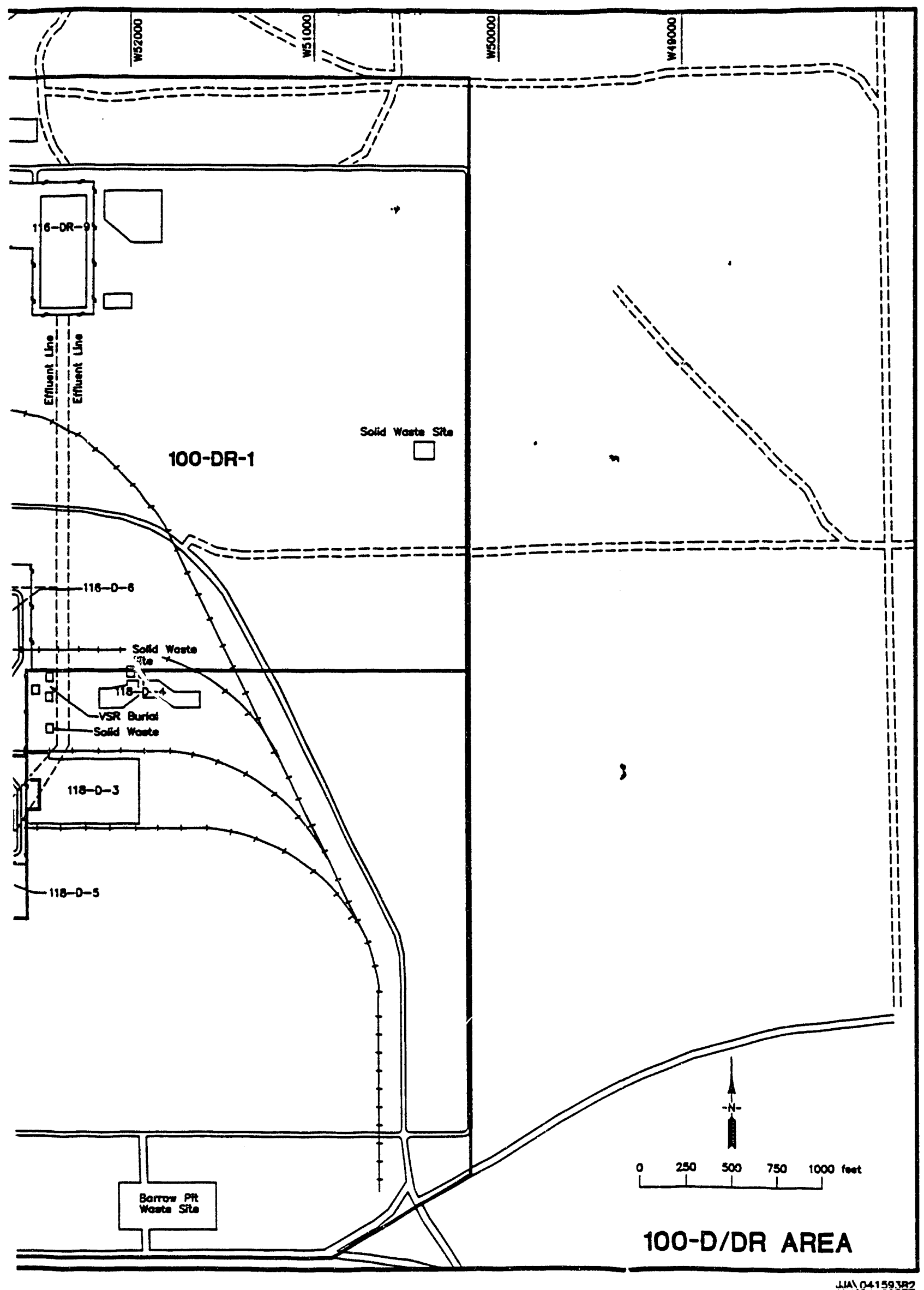




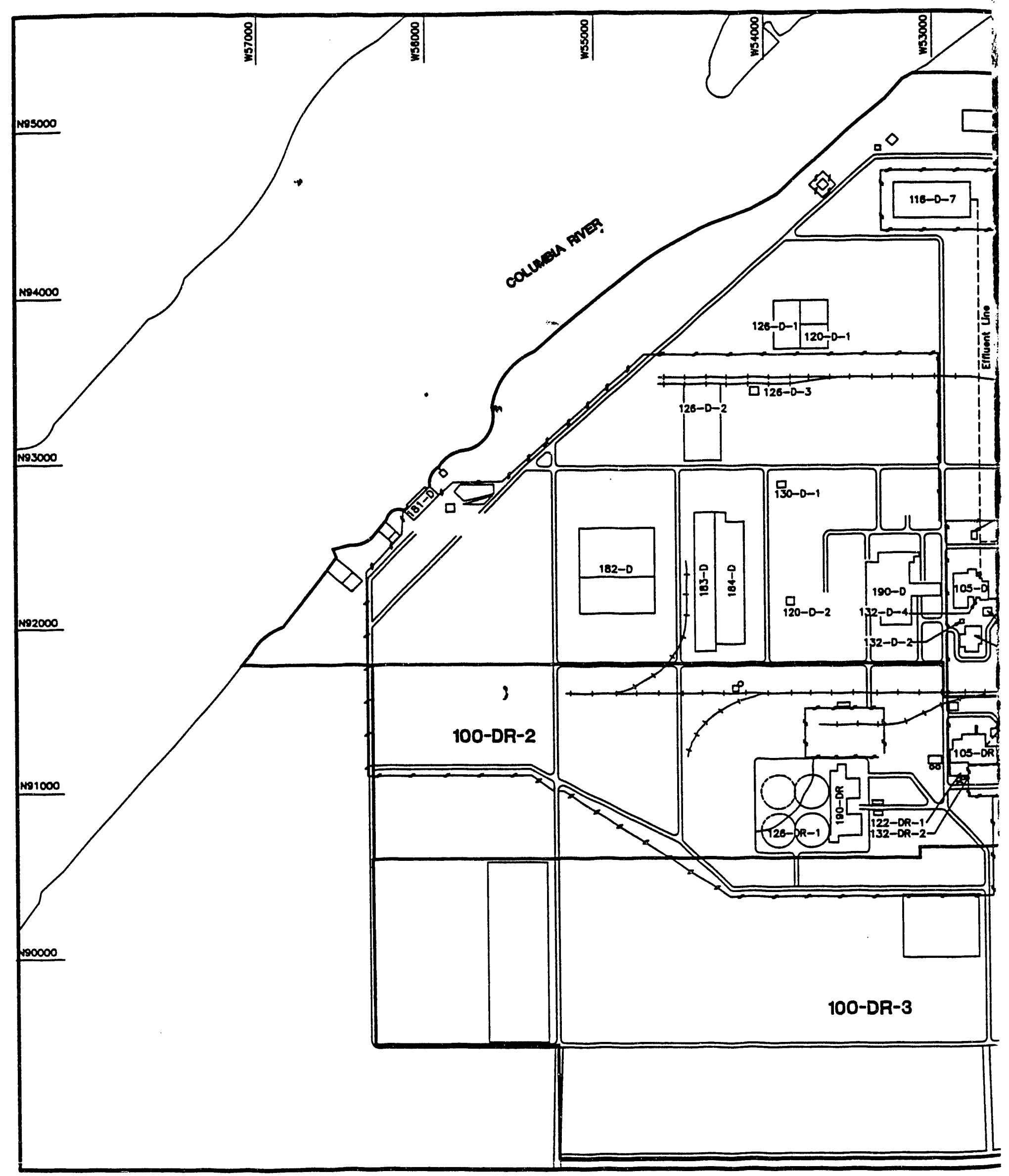


WHC-SD-EN-TI-181 Rev. 0

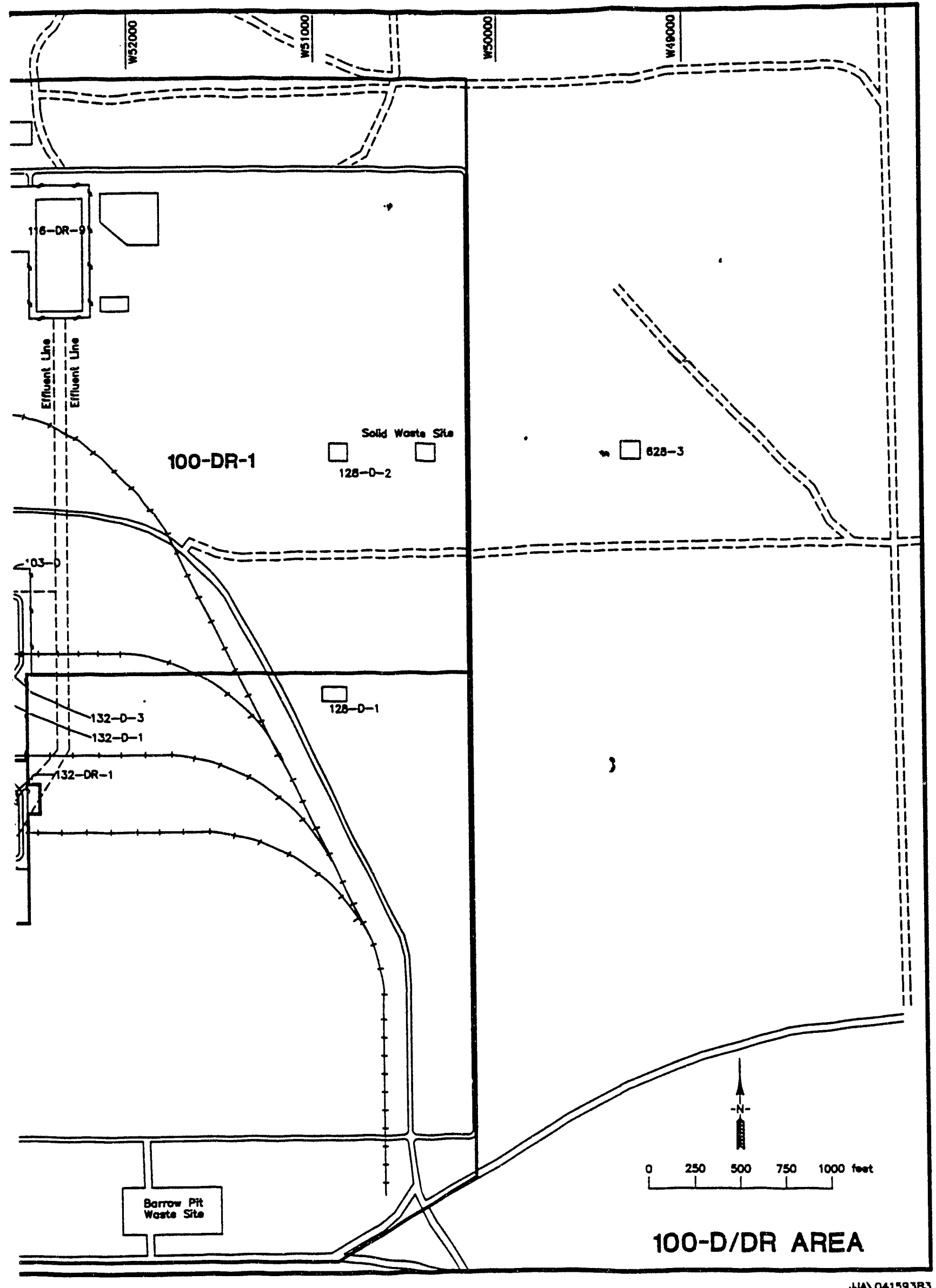




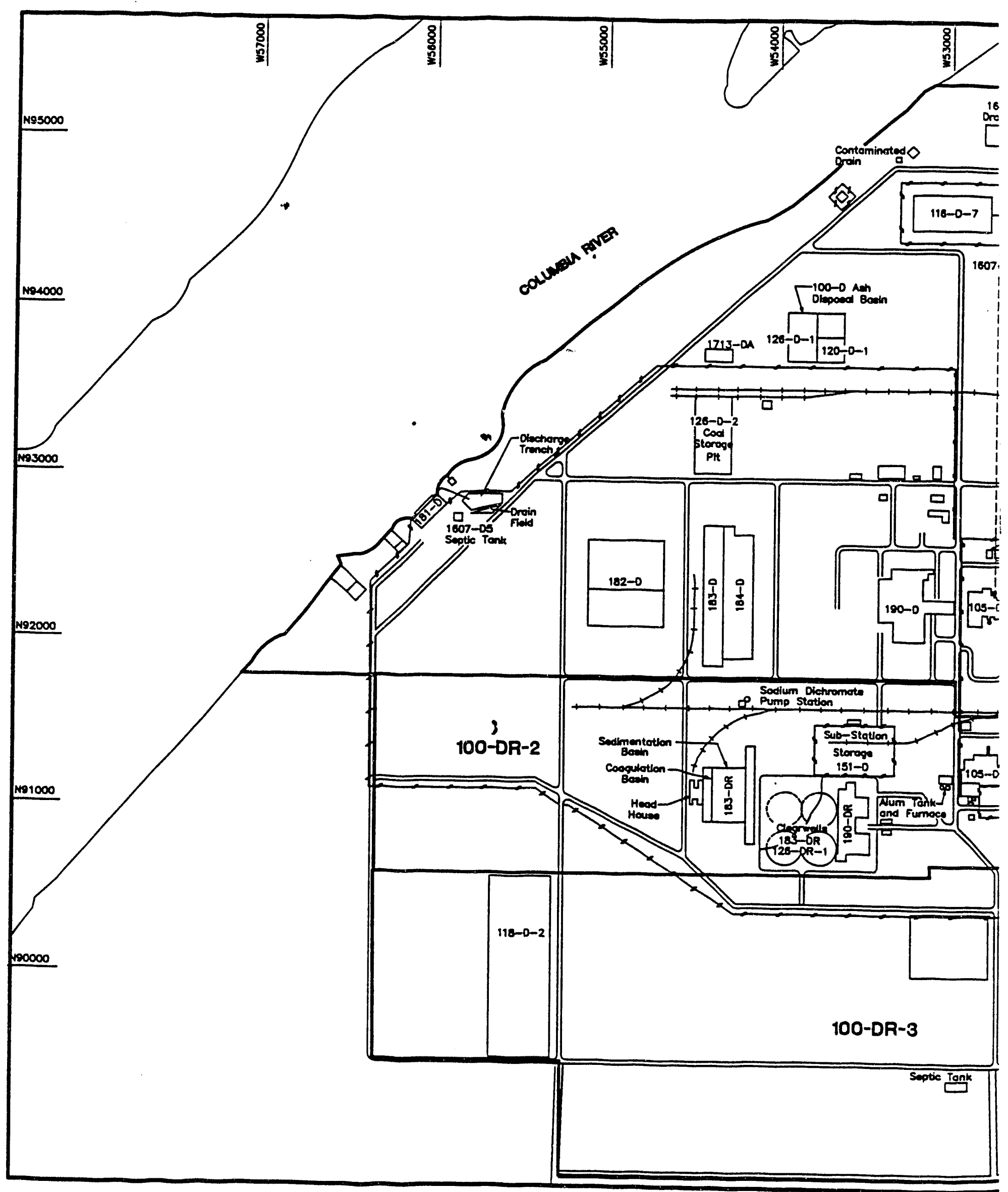




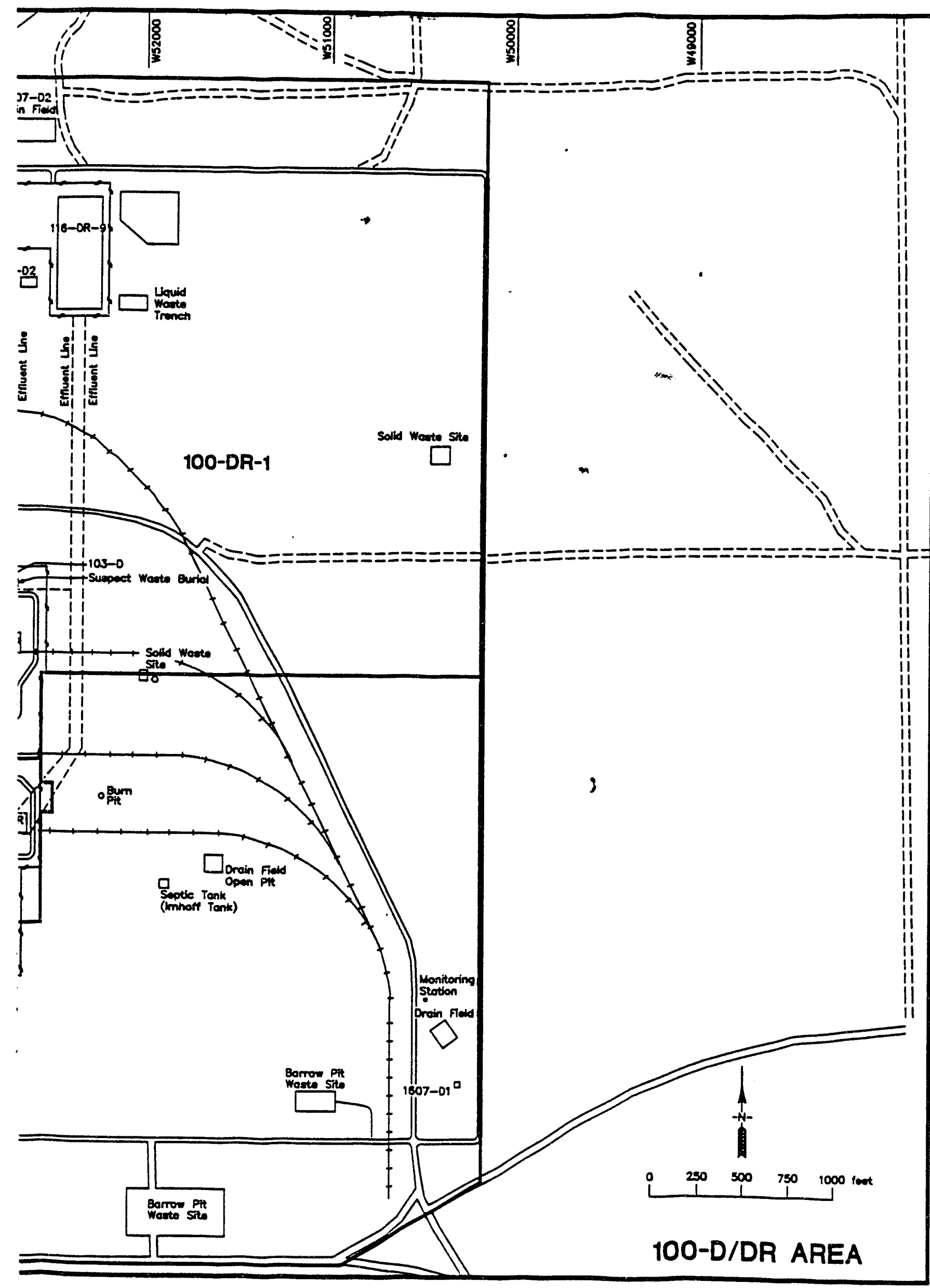


WHC-SD-EN-TI-181, Rev. 0

\title{
APPENDIX C \\ RADIONUCLIDE INVENTORY \\ TABLES
}

\begin{abstract}
REFERENCE
Dorian, JJ and VR Richards, 1978, Radiological Characterization of Retired 100 Areas, UNI-946, United Nuclear Industries, Richland, Washington.
\end{abstract}


WHC-SD-EN-TI-181-Rev.0

This page intentionally left blank 
WHC-SD-EN-TI-181 Rev. 0

Table 3.4-14

116-D-1A

105-D STORAGE BASIN TRENCH \#i

Potentially Contaminated Soil Column

$$
\begin{aligned}
\text { Volume } & =150^{\prime} \times 40^{\prime} \times 35^{\prime}=2.1 \times 10^{5} \mathrm{ft}^{3} \\
\text { Mass } & =1.4 \times 10^{10} \mathrm{~g}
\end{aligned}
$$

\section{Radionuclide}

Pu-238

$\mathrm{Pu}-239 / 240$

$\mathrm{Sr}-90$

$\mathrm{H}-3$

Eu-152

Co. 50

Eu-154

Cs-13/t

Cs-137

Eu-155

U
Ave. $\mathrm{pCi} / \mathrm{g}$

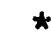

$1.4 \times 10^{0}$

1. $1 \times 10^{1}$

$9.7 \times 10^{1}$

$7.6 \times 10^{1}$

2. $9 \times 10^{1}$

1. $6 \times 10^{1}$

$6.9 \times 10^{-1}$

$9.0 \times 10^{1}$

$7.6 \times 10^{0}$

$2.7 \times 10^{-1}$
Curies

0.0

$2.0 \times 10^{-2}$

$1.5 \times 10^{-1}$

1.4

1.1

$4.1 \times 10^{-1}$

$2.2 \times 10^{-1}$

$9.7 \times 10^{-3}$

1.3

$1.1 \times 10^{-1}$

$3.8 \times 10^{-3}$

Total Curies $=4.7$ 


\section{Table 3.4-15}

$$
116-D-1 B
$$

105-D STORAGE BASIN TRENCH \#2

\section{Potentially Contaminated Soll Column}

$$
\begin{aligned}
& \text { Volume }=150^{\prime} \times 40^{\prime} \times 35^{1}=2.1 \times 10^{5} \mathrm{ft}^{3} \\
& \text { Mass }=1.4 \times 10^{10} \mathrm{~g}
\end{aligned}
$$

Radionuclide

Pu-238

Pu-239/240

Sr-90

$\mathrm{H}-3$

Eu-152

Co-60

Eu-154

Cs- 134

Cs-137

Eu- 155

U

C-14
Ave. $\mathrm{pCi} / \mathrm{g}$

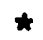

$4.8 \times 10^{-1}$

$1.4 \times 10^{1}$

$1.4 \times 10^{1}$

$3.1 \times 10^{1}$

$1.4 \times 10^{1}$

$5.9 \times 10^{0}$

$3.5 \times 10^{-1}$

$4.4 \times 10^{1}$

$6.3 \times 10^{1}$

$1.8 \times 10^{-1}$

No data
Curies

0.0

$6.7 \times 10^{-3}$

$2.0 \times 10^{-1}$

$2.0 \times 10^{-1}$

$4.3 \times 10^{-1}$

$2.0 \times 10^{-1}$

$8.3 \times 10^{-2}$

$4.9 \times 10^{-3}$

$6.2 \times 10^{-1}$

$8.8 \times 10^{-1}$

$2.5 \times 10^{-3}$

\section{Total Curies $=2.6$}


WHC-SD-EN-TI-181 Rev. 0

Table 3.4-16

116-DR-3

105-DR STORAGE BASIN TRENCH

Potentially Contaminated Soil Column

$$
\begin{aligned}
& \text { Volume }=60^{\prime} \times 40^{\prime} \times 15^{\prime}=3.6 \times 10^{4} \mathrm{ft}^{3} \\
& \text { Mass }=2.5 \times 10^{9} \mathrm{~g}
\end{aligned}
$$

Radionuclide

$\mathrm{Pu}-238$
$\mathrm{Pu}-239 / 240$
$\mathrm{Sr}-90$
$\mathrm{H}-3$
$\mathrm{Eu}-152$
$\mathrm{Co}-60$
$\mathrm{Eu}-154$
$\mathrm{Cs}-134$
$\mathrm{Cs}-137$
$\mathrm{Eu}-155$

Ave. $\mathrm{pCi} / \mathrm{g}$

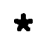

1. $3 \times 10^{0}$

$2.5 \times 10^{1}$

$1.3 \times 10^{2}$

$1.2 \times 10^{1}$

$1.2 \times 10^{1}$

$2.4 \times 10^{0}$

$7.0 \times 10^{-2}$

$1.7 \times 10^{1}$

$3.2 \times 10^{-1}$
Curies

0.0

$3.3 \times 10^{-3}$

$6.3 \times 10^{-2}$

$3.3 \times 10^{-1}$

$3.0 \times 10^{-2}$

$3.0 \times 10^{-2}$

$6.0 \times 10^{-3}$

$1.8 \times 10^{-4}$

4. $3 \times 10^{-2}$

$8.0 \times 10^{-4}$

Total Curies $=5.1 \times 10^{-1}$ 
HHC-SD-EN-TI-181 Rev. 0

UNI-946

\section{Table 3.4-17}

$116-D R-4$

105-DR PLUTO CRIB

Potentially Contaminated Soil column

Vol ume $=30^{\prime} \times 30^{\prime} \times 25^{\prime}-2.3 \times 10^{4} \mathrm{ft}^{3}$

Mass $=1.6 \times 10^{9} \mathrm{~g}$

Radionuclide

$\mathrm{Pu}-238$

$\mathrm{Pu}-239 / 240$

Sr-90

H-3

Eu-152

Co-60

Eu-154

Cs -134

Cs-137

Eu-155
Ave. $\mathrm{pCi} / \mathrm{g}$

$+$

$6.3 \times 10^{-2}$

$3.3 \times 10^{0}$

*

$3.0 \times 10^{0}$

$2.2 \times 10^{0}$

*

$1.6 \times 10^{-2}$

$2.9 \times 10^{1}$

$3.6 \times 10^{-1}$
Curies

0.0

$1.0 \times 10^{-4}$

$5.3 \times 10^{-3}$

0.0

$4.8 \times 10^{-3}$

$3.5 \times 10^{-3}$

0.0

$2.6 \times 10^{-5}$

$4.6 \times 10^{-2}$

$5.8 \times 10^{-4}$

Total Curies $=6.0 \times 10^{-2}$

100-DR 117 Seal Pit Drain Crib

105-DR Inkwell Crib (3X. Liquid)

< ImCi

116-D2

Pluto Crib. No UST data

$<b \mathrm{~kg}$. On any sample from requested. No field indication

$116=03 \& 4$ 108-D Cribs

$<.1$ Curie 


\section{TABLE 3.3-1}

BETA-GAMMA CONCENTRATIONS WITHIN THE 100 AREA MISCELLANEOUS CRIBS AND TRENCHES

\begin{tabular}{|c|c|c|c|}
\hline Crib No. & Designation & $\frac{\text { Ave. Beta-Garma }}{(\mathrm{pC} \mathrm{i} / \mathrm{g})}$ & $\frac{\text { Max. Beta-Gamma }}{(\mathrm{pCi} / \mathrm{g})}$ \\
\hline $116-B-2$ & $\begin{array}{l}\text { 105-B Storage Basin } \\
\text { Trench }\end{array}$ & $9.0 \times 10^{1}$ & $1.6 \times 10^{2}$ \\
\hline $116-B-3$ & 105-B Pluto Crib & $1.7 \times 10^{3}$ & $4.0 \times 10^{3}$ \\
\hline $116-B-5$ & 108-B Crib & $1.6 \times 10^{4}(\mathrm{H}-3)$ & $7.3 \times 10^{4}(\mathrm{H}-3)$ \\
\hline $116-B-6-1$ & $111-8$ Crib \#1 & $1.4 \times 10^{3}$ & $2.6 \times 10^{3}$ \\
\hline $116-B-6-2$ & $111-B$ Crib \#2 & $1.6 \times 10^{1}$ & $1.6 \times 10^{1}$ \\
\hline $116-c-2$ & 105-C Pluto Crib & $1.9 \times 10^{2}$ & $2.8 \times 10^{2}$ \\
\hline $116-c-2-2$ & $\begin{array}{l}\text { 105-C Pluto Crib } \\
\text { Sand Filter }\end{array}$ & $4.2 \times 10^{4}$ & $7.3 \times 10^{6}$ \\
\hline $116-D-1 A$ & $\begin{array}{l}\text { 105-D Storage Basin } \\
\text { Trench \#1 }\end{array}$ & $3.3 \times 10^{2}$ & $9.0 \times 10^{2}$ \\
\hline $116-D-1 B$ & $\begin{array}{l}\text { 105-D Storage Basin } \\
\text { Trench } \# 2\end{array}$ & $2.0 \times 10^{2}$ & $1.1 \times 10^{3}$ \\
\hline $116-D-2$ & 105-D Pluto Cribl & NA & $N A$ \\
\hline $116-D-3 \& 4$ & 108-D Cribs \#1\&22 & $<3.6 \times 10^{-1}$ & $<3.6 \times 10^{-1}$ \\
\hline $116-D R-3$ & $\begin{array}{l}\text { 105-DR Storage Basin } \\
\text { Trench }\end{array}$ & $1.7 \times 10^{2}$ & $3.1 \times 10^{2}$ \\
\hline \multirow[t]{2}{*}{$116-D R-4$} & 105-DR Pluto Crib & $3.8 \times 10^{1}$ & $7.0 \times 10^{1}$ \\
\hline & 117-DR Crib & $<1.7 \times 10^{-1}(\mathrm{H}-3, \mathrm{C}-14)$ & $<1.7 \times 10^{-1}(\mathrm{H}-3, \mathrm{C}-14)$ \\
\hline 116-KE-1 & 115-KE Crib & $4.5 \times 10^{5}$ & $8.6 \times 10^{5}$ \\
\hline $116-K E-2$ & 1706-KER Crib & $4.3 \times 10^{3}$ & $1.1 \times 10^{4}$ \\
\hline $116-K W-1$ & $115-\mathrm{KW}$ Crib & $4.5 \times 10^{5}(H-3, C-14)$ & $8.6 \times 10^{5}(H-3, C-14)$ \\
\hline $116-F-1$ & Lewis Canal & $3.4 \times 10^{1}$ & $6.4 \times 10^{2}$ \\
\hline $116-F-3$ & $\begin{array}{l}\text { 105-F Storage Basin } \\
\text { Trench }\end{array}$ & $3.9 \times 10^{-1}$ & $5.8 \times 10^{-1}$ \\
\hline $116-F-4$ & 105-F Pluto Crib & $2.9 \times 10^{3}$ & $9.0 \times 10^{3}$ \\
\hline $116-F-5$ & Ball Washer Crib & $7.7 \times 10^{-1}$ & $7.7 \times 10^{-1}$ \\
\hline $116-F-6$ & $\begin{array}{l}\text { 1608-F Liquid Waste } \\
\text { Disposal Trench }\end{array}$ & $1.6 \times 10^{2}$ & $5.3 \times 10^{2}$ \\
\hline
\end{tabular}


TABLE 3.3-1 (Cont'd) BETA-GAMMA CONCENTRATIONS WITHIN THE 100 AREA
MISCELLANEOUS CRIBS AND TRENCHES

Crib No.

Designation

$\frac{\text { Ave. Beta-Gamma }}{(\mathrm{pCi} / \mathrm{g})}$

$\frac{\text { Max. Beta-Gamma }}{(\mathrm{pCi} / \mathrm{g})}$

\begin{tabular}{|c|c|}
\hline $116-F-7$ & $117-F$ Crib \\
\hline $116-5-10$ & $\begin{array}{l}\text { Perf Decontamination } \\
\text { Drain }\end{array}$ \\
\hline $116-H-2$ & 1608-H Trench \\
\hline $116-H-3$ & $\begin{array}{l}\text { 105-H Dummy } \\
\text { Decontamination } \\
\text { Drain }\end{array}$ \\
\hline
\end{tabular}

$3.5 \times 10^{-1}$

$4.0 \times 10^{2}$

$3.5 \times 10^{-1}$

$4.0 \times 10^{2}$

$9.7 \times 10^{2}$

$5.4 \times 10^{1}$

$2.2 \times 10^{2}$

$1.2 \times 10^{2}$

$3.6 \times 10^{2}$

iNA-No Analysis. No contamination measurable with field instrumentation
was detected in samples taken from two test holes was detected in samples taken from two test holes drilled $28^{\prime}$ and $30^{\prime}$
deep.

${ }^{2}$ Only : one sample analyzed. The sample had the highest field count of the
samples taken from $116-D-3 \& 4$. 
WHC-SD-EN-TI-181. Rev. 0

TABLE 3.3-2

PLUTONIUM CONCENTRATIONS WITHIN THE 100 AREA

MISCELLANEOUS CRIBS AND TRENCHES

Crib No. Designation $\frac{\text { Ave. Pu-238 }}{(\mathrm{pCi} / \mathrm{g})} \frac{\mathrm{Max} \cdot \mathrm{Pu}-238}{(\mathrm{pCi} / \mathrm{g})} \frac{\text { Ave. } \mathrm{Pu}-239 / 240}{(\mathrm{pCi} / \mathrm{g})} \frac{\mathrm{Max} \cdot \mathrm{Pu}-239 / 240}{(\mathrm{pCi} / \mathrm{g})}$

\begin{tabular}{|c|c|c|c|c|c|}
\hline $116-B-2$ & $\begin{array}{l}\text { 105-B Storage } \\
\text { Basin Trench }\end{array}$ & * & $\star$ & $6.4 \times 10^{-1}$ & $1.4 \times 10^{0}$ \\
\hline $116-8-3$ & $\begin{array}{l}\text { 105-B Pluto } \\
\text { Crib }\end{array}$ & $1.1 \times 10^{-1}$ & $3.3 \times 10^{-1}$ & $5.6 \times 10^{0}$ & $8.6 \times 10^{0}$ \\
\hline $116-B-5$ & 108-B Crib & $\star$ & * & $\star$ & $\star$ \\
\hline $116-B-6-1$ & $111-B$ Crib \#1 & $\star$ & * & $2.3 \times 10^{0}$ & $3.6 \times 10^{0}$ \\
\hline $116-B-6-2$ & 111-B Crib \#2 & * & * & * & $\star$ \\
\hline $116-c-2$ & $\begin{array}{l}\text { 105-C Pluto } \\
\text { Crib }\end{array}$ & $\star$ & $\star$ & $\star$ & $\star$ \\
\hline $116-c-2-2$ & $\begin{array}{l}\text { 105-C Pluto } \\
\text { Crib Sand } \\
\text { Filter }\end{array}$ & $1.9 \times 10^{1}$ & $1.6 \times 10^{3}$ & $1.9 \times 10^{1}$ & $1.5 \times 10^{3}$ \\
\hline $116-D-1 A$ & $\begin{array}{l}\text { 105-D Storage } \\
\text { Basin Trench \#1 }\end{array}$ & * & $\star$ & $1.4 \times 10^{0}$ & $6.1 \times 10^{0}$ \\
\hline $116-D-1 B$ & $\begin{array}{l}\text { 105-D Storage } \\
\text { Basin Trench \#2 }\end{array}$ & $\star$ & $\star$ & $4.8 \times 10^{-1}$ & $2.3 \times 10^{0}$ \\
\hline $116-D-2$ & $\begin{array}{l}\text { 105-D Pluto } \\
\text { Crib }\end{array}$ & NA & & NA & \\
\hline $116-D-3 \& 4$ & 108-D Cribs $\frac{4}{11} 22$ & $\star$ & $\star$ & $3.3 \times 10^{-1}$ & $3.3 \times 10^{-1}$ \\
\hline $116-D R-3$ & $\begin{array}{l}\text { 105-DR Storage } \\
\text { Basin Trench }\end{array}$ & $\star$ & $\star$ & $1.3 \times 10^{0}$ & $3.8 \times 10^{0}$ \\
\hline \multirow[t]{2}{*}{$116-D R-4$} & $\begin{array}{l}\text { 105-DR Pluto } \\
\text { Crib }\end{array}$ & $\star$ & $\star$ & $6.3 \times 10^{-2}$ & $1.9 \times 10^{-1}$ \\
\hline & 117-DR Crib & $\star$ & * & $\star$ & $\star$ \\
\hline $116-K E-1$ & 115-KE Crib & NA & & $N A$ & \\
\hline $116-K E-2$ & 1706-KER Crib & * & $\star$ & $2.1 \times 10^{0}$ & $6.1 \times 10^{0}$ \\
\hline $116-K W-1$ & 115-KW Crib & * & $\star$ & $\star$ & $\star$ \\
\hline $116-F-1$ & Lewis Canal & * & * & $6.2 \times 10^{-2}$ & $9.9 \times 10^{-1}$ \\
\hline $116-F-3$ & $\begin{array}{l}\text { 105-F Storage } \\
\text { Basin Trench }\end{array}$ & $\star$ & $\star$ & $\star$ & $\star$ \\
\hline
\end{tabular}


WHC-SD-EN-TI-181 Rev. 0

\section{TABLE 3.3-2 (Cont'd)}

PLUTONIUM CONCENTRATIONS WITHIN THE 100 AREA MISCELLANEOUS CRIBS AND TRENCHES

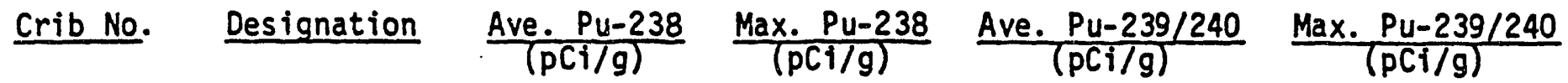

\begin{tabular}{|c|c|c|c|c|c|}
\hline $116-F-4$ & $\begin{array}{l}\text { 105-F Pluto } \\
\text { Crib }\end{array}$ & $4.7 \times 10^{-1}$ & $1.5 \times 10^{0}$ & $3.5 \times 10^{3}$ & $1.1 \times 10^{2}$ \\
\hline $116-F-5$ & $\begin{array}{l}\text { Ball Washer } \\
\text { Crib }\end{array}$ & * & * & * & * \\
\hline $176-F-6$ & $\begin{array}{l}1608-F \text { Liquid } \\
\text { Waste Disposal } \\
\text { Trench }\end{array}$ & * & * & $2.4 \times 10^{-1}$ & $7.6 \times 10^{-1}$ \\
\hline $116-F-7$ & $117-F$ Crib & $\star$ & $\star$ & $1.0 \times 10^{-1}$ & $1.0 \times 10^{-1}$ \\
\hline $116-F-10$ & $\begin{array}{l}\text { Perf Deconta- } \\
\text { mination Drain }\end{array}$ & * & $\star$ & $2.6 \times 10^{-1}$ & $8.7 \times 10^{-1}$ \\
\hline $116-\mathrm{H}-2$ & 1608-H Trench & $\star$ & $\star$ & $1.6 \times 10^{-2}$ & $1.3 \times 10^{-1}$ \\
\hline $116-\mathrm{H}-3$ & $\begin{array}{l}\text { 105-H Dummy } \\
\text { Decontamination } \\
\text { Drain }\end{array}$ & * & $\star$ & $2.7 \times 10^{-1}$ & $2.7 \times 10^{-1}$ \\
\hline
\end{tabular}


TABLE 3.3-3

RADIOACTIVE INVENTORIES WITHIN THE 100 AREA MISCELLANEOUS CRIBS AND TRENCHES

Crit No.

$116-8-2$

$116-B-3$

$116-B-5$

$116-B-6-1$

$116-B-6-2$

$116-C-2$

116-C-2-2

$116-D-1 A$

$116-D-1 B$

116-D-2

116-D-3\&4

$116-D R-3$

116-DR-4

117-DR Crib

116-KE-1

116-KE-2

116-KW-1

116-F-1

$116-F-3$

$116-F-4$

$116-F-5$

116-F-6
Designation

105-B Storage Basin

Trench

105-B Pluto Crib

108-B Crib

111-B Crib \#1

111-B Crib \#2

105-C Pluto Crib

105-C Pluto Crib Sand

Filter

105-D Storage Basin

Trench \#1

105-D Storage Basin

Trench \#2

105-D Pluto Crib

108-D Cribs \#1\&2

105-DR Storage Basin

Trench

105-DR Pluto Crib

115-KE Crib

1706-KER Crib

115-KW Crib

Lewis Canal

105-F Storage Basin

105-F Pluto Crib

Ball Washer Crib

1608-F Liquid Waste

Disposal Trench
Total Curies

$3.7 \times 10^{-1}$

2.0

$3.0 \times 10^{2}$ (Tritium)

1.3

$1.2 \times 10^{-2}$

1.8

260

4.7

2.6

$<0.1$

$<0.1$

$5.1 \times 10^{-1}$

$6.0 \times 10^{-2}$

< $\mathrm{mCi}$

$<240(\mathrm{H}-3, \mathrm{C}-14)$

38

$240(H-3, C-14)$

3.4

$2.1 \times 10^{-3}$

3.5

$9.2 \times 10^{-4}$

6.5 
TABLE 3.3-3 (Cont'd)

RADIOACTIVE INVENTORIES WITHIN THE 100 AREA

MISCELLANEOUS CRIBS AND TRENCHES

Crib No.

$116-\mathrm{F}-7$

$116-F-10$

$116-\mathrm{H}-2$

$116-\mathrm{H}-3$
Designation

117-F Crib

Perf. Decontamination

Drain

1608-H Trench

105-H Dummy Decontamination Drain
Total Curies

$1.4 \times 10^{-4}$

$1.2 \times 10^{-1}$

1.4

$7.0 \times 10^{-2}$ 
WHC-SD-EN-TI-181, Rev. 0

APPENDIX D

INTERNAL CORRESPONDENCE 
WHC-SD-EN-TI-181-Rev.0

This page intentionally left blank

D-2 
WHC-SD-EN-TI-181, Rev. 0

\section{CONTENTS}

Telephone Interview of Wally Howell by Dennis DeFord, Summary . . . . D-5 DSI to SN Luke from MJ Galbraith . . . . . . . . . . . . . . D-7 DSI to DH DeFord from RW Carpenter ................ D-11

\section{LIST OF FIGURES}

D-1 Plot of Mercury Above Background in 100-D Settling Pond . . . . D-8

D-2 Plot of Mercury Above Background in 100-D Settling Pond . . . . . D-9 
WHC-SD-EN-TI-181-Rev.0

This page intentionally left blank

$D-4$ 
TELEPHONE INTERVIEW

WALLY HOWELL, RETIRED HPT

OCT $1 ; 1992$

\section{RE: PLUTO CRIBS}

Wally worked at Hanford from 1947 until 1986 when he retired. Was a reactor site HPT from 1947 to 1963. Then was a shift supervisor (HPT), and then into training.

Re: pluto cribs.

These were used to isolate the coolant flow from a process tube which had a leaking fuel element in it until the tube could be discharged. A pluto valve was installed on back end of the subject tube and a rubber hose connected. Cooling water went through the hose to the pluto crib. He isn't sure why it was called the pluto crib.

The crib was a wooden $10 \mathrm{ft}$ cube set in the ground with its upper surface at grade. It had a hatch which was opened to accept the rubber hose, but kept closed at all other times. Pluto cribs were discontinued when liquid waste trenches came into use.

Prior to pluto cribs, fuel ruptures were not isolated and the contaminated cooling water was flushed to the river with the rest of the cooling water. They began to be used when concern was raised concerning contamination to the river, maybe when OR Governor Hatfield began to complain.

He estimates that they were used from 1950 to 1956 , which agrees with WIDS data. Note that fuel ruptures began in May 1948, following the first power level increases. 
WHC-SD-EN-TI-181-Rev.0

This page intentionally left blank

D-6 
DON'T SAY IT -.- Write It!

TO: S. N. Luke

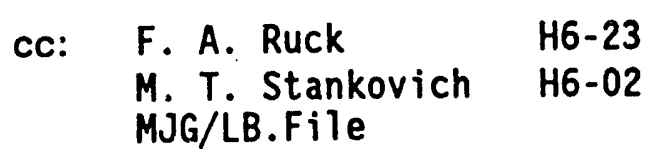

DATE: January 14, 1993

FROM: M. J. Galbraith $N$ H6-02 Telephone: $372-3760$

SUBJECT: $100-D$ Ponds Mercury Concentration

The attached plots illustrate the mercury above background in the 100-D Ponds. I have examined the other metals, VOA, semiVOA and PCB data and there are only a few other contaminants that will be above coal ash background (arsenic, a $\mathrm{PCB}$, etc). Only the one PCB result alone designates. However, not all of the data is here so I can't do a cation-anion combination. I al so cannot yet 1 ist background results. The 100-D Ponds closure option will have to consider CERCLA contaminants above background but not designating. Members of Ecology will probably insist that soil above background but not designating be transported to a landfill complying with WAC-173-304 (one liner, lysimeters, etc). We should be prepared for this request. 


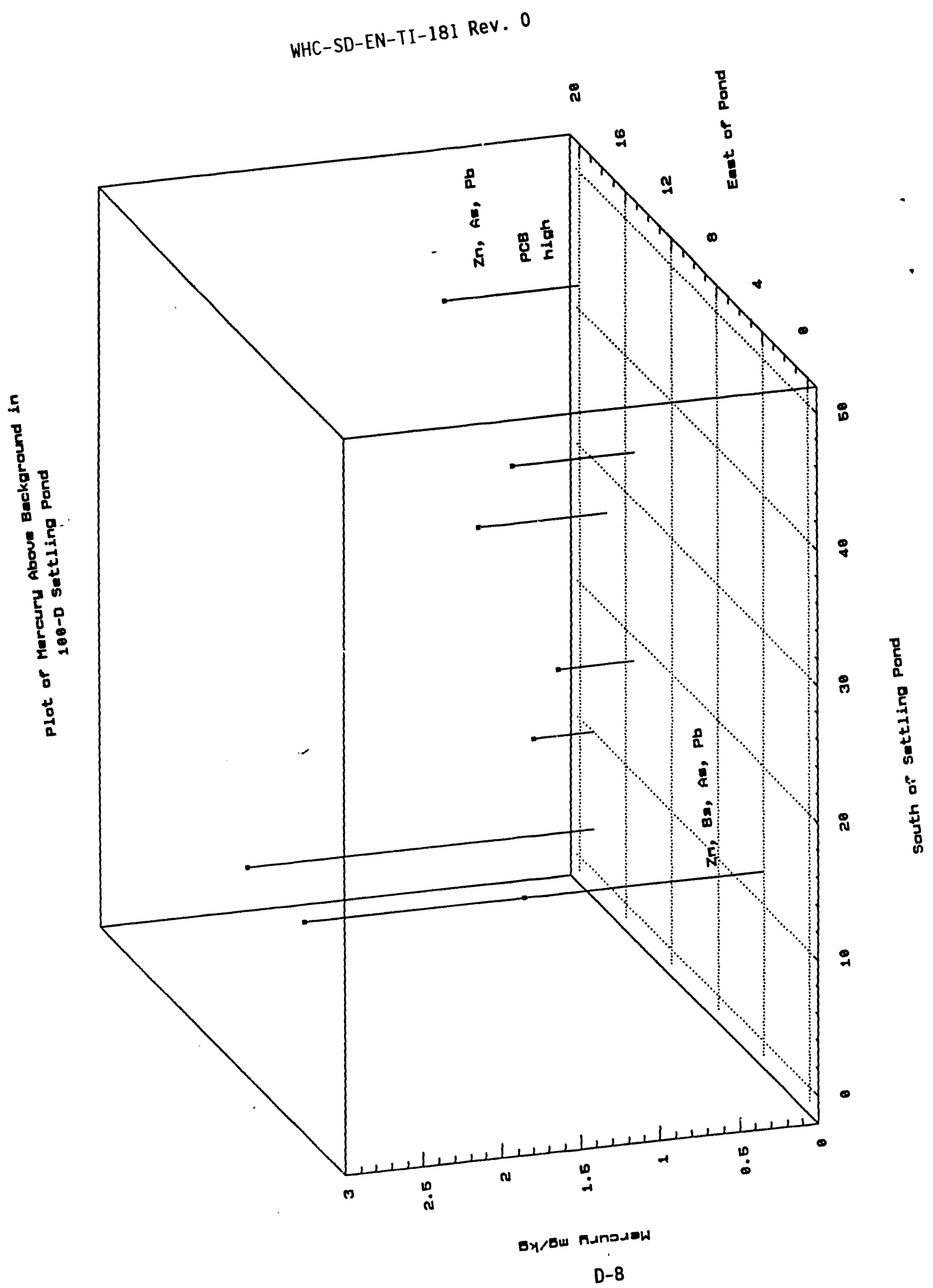




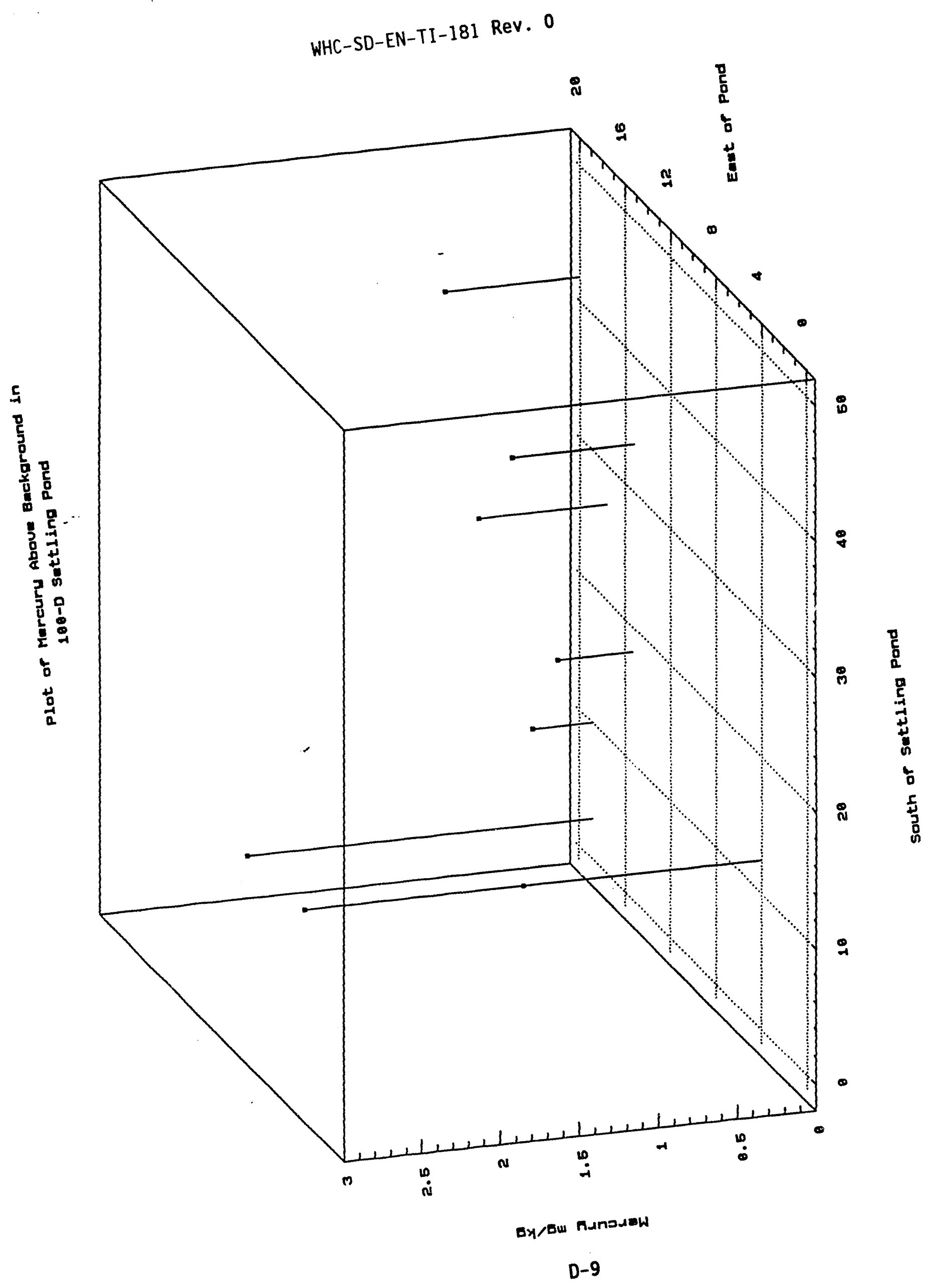


WHC-SD-EN-TI-181-Rev.0

This page intentionally left blank 
WHC-SD-EN-TI-181 Rev. 0

DON'T SAY IT -..- Write It!

TO: DH DeFord

H6-01
DATE: May 27, 1993

FROM: RW Carpenter

H6-01

cc:

SUBJECT: Tour of the 100-D Area with RK Wahlen 05-16-92

On May 16th, 1993 Ralph Wahlen and I toured the 100-D Area to review facilities and waste sites located within the 100-D Area. The following observations were made by Ralph that are revelant to the $100-D$ and $100-H$ Technical Baseline Reports.

During the tour of 100-D Area, I asked Ralph about the 100-H Area Pluto crib that was moved to a new location for the placement of the confinement filter building. He stated that they removed all detectable contamination from beneath the old Pluto Crib before reusing the site for construction of the new facility.

While we were in the area Ralph told me about a small outfall structure located just south of the 100-Area fence on the riverbank that was used to discharge rain runoff in the 190-DR Tankwell Pit. He said that it consisted of drains, sump and lift pump in the tank pit and piping to the outfall. The outfall itself was demolished at about the same time as the 1907-DR Outfall and was located just downstream of the small concrete block telephone building. This outfall structure is a new waste site for the 100-D Area and I could find no other documentation or drawings to verify it's existence.

Other than this new information the tour was very helpful in that Ralph was able to clarify information already known about many of the waste sites in the 100-D Area.

Ralph did substantiate the fact that the 184-D Coal pit was not very well controlled when it was being used as a burial grourd giving credibility to JJ Jeskey's comments. He thought that the 190-DR Tankweil Pit was much better controlled and would be surprised if any unknown wastes were disposed of there. He felt that the asbestos contamination in the pit was most likely due to insulation removal from the piping systems in the pit.

Finally he confirmed that the lead flashing used in the 186-D Waste Acid Reservoir was buried in situ. 
WHC-SD-EN-TI-181, Rev. 0

\section{APPENDIX E \\ 100-DR-2 OPERABLE UNIT \\ WORK PLAN CHARACTERIZATION STRATEGY}

E-1 
WHC-SD-EN-TI-181-Rev.0

This page intentionally left blank

$E-2$ 
WHC-SD-EN-TI-181 Rev. 0

100-DR-2 OPERABLE UNIT

WORK PLAN CHARACTERIZATION STRATEGY

SITE

$116-D-8$

$116-D R-3$

$116-D R-4$

\section{DESCRIPTION}

100-D Cask Storage Pad

The site was active from 1946

through 1975. Not included in the TPA action plan.

The unit is a concrete pad with a drain. The drain facilitated pad decontamination and rain runoff. The drain discharged into the 105-DR process sewer.

Waste Types \& Amounts: This site contains trace amounts of radionuclides and decontamination chemicals.

The pad contains one contaminated drain which is piped to a French drain.

All casks have been removed, and an asphalt emulsion coating was placed on the concrete to fix all surface contamination.

105-DR Storage Basin Trench $60^{\prime} \times 40^{\prime} \times 10^{\prime}$

The site was active during 1955. The site is included in TPA action plan. The site received $4.000,000$ liters of contaminated sludge and water removed from 105-DR Fuel Storage Basin.
PLANNED CHARACTERIZATION

One shallow borehole or a pit
105-DR Pluto Crib

$10^{\prime} \times 10^{\prime} \times 15^{\prime}$

The site was active from 1952 to 1953. The site is included in the TPA action plan. The site received 4,000 liters of liquid wastes from isolated tubes containing ruptured fuel elements in the 105-DR Fuel Storage Basin.
Will compare with 100 DR-1 similar site. May not need any intrusive work.
Will compare similar crib in DR-1. May not need any more work.

116-DR-6 1608-DR Liquid Disposal Trench Shallow borehole. 
$50^{\prime} \times 10^{\prime} \times 10^{\prime}$

The site was active from 1953

through 1965. The site is included

in the TPA action plan. The site received $7,000,000$ liters of diverted coolant during the Ball $3 X$ upgrade. It al so received diverted water during a reactor shutdown.

116-DR-7 105-DR Inkwell Crib $5^{\prime} \times 5^{\prime} \times 10^{\prime}$ Borehole if Rad, Pit if The site was active during 1953. Chemical.

The site is included in TPA action plan.

The site received 4,000 liters of liquid potassium borate from the $3 X$ System prior to the Ball $3 x$ System upgrade.

$116-D R-8$

$117-D R-C r i b$ $10^{\prime} \times 10^{\prime} \times 10^{\prime}$

Analogous with 100-DR-1.

The site was active from 1960 through 1964 .

The site is included in the TPA action plan.

The site received 240, 000 liters of drainage

from the containment system 117 Building seal

pits.

118-D-5 Ba11 3X Burial Ground

Two trenches, $40^{\prime} \times 20^{\prime} \times 10^{\prime}$ each

Nonintrusive work.

The site was active during 1954. The site is

included in the TPA action plan.

The site received 10 cubic meters of

thimbles removed from the 105-DR Reactor

during the Ball $3 X$ work in 1954.

118-DR-2 105-DR Reactor Building

The site was active from October 3,1950

N/A

through December 30, 1964. The site is

not included in the TPA action plan. The

site contains an estimated $13,500 \mathrm{Ci}$ of

radionuclides, 94 tons of lead, $100 \mathrm{cu} \mathrm{ft}$ of

asbestos and $5001 \mathrm{~b}$ of cadmium.

122-DR-1 105-DR Sodium Fire Facility

The site was active from 1972

\author{
RCRA TSD Facility \\ Coordinate with Closure. \\ Part A Permit, \\ Part B Permit, \\ Interim Closure Plan \\ has been submitted for \\ this site.
}

through 1986. The site is not included

in the TPA action plan. The site wastes consist of sodium, lithium, and sodium-potassium alloy. 
Approximately $20,000 \mathrm{~kg}$ are managed at this facility each year. The facility al so stores up to $20,000 \mathrm{~L}$ of dangerous wastes.

126-DR-1 $190-C R$ Clearwell Tank Pit Analogous with DR-1.
$42^{\prime} \times 525^{\prime}$ (no depth listed)
The site has been active since 1970's.
The site is included in the TPA action plan.
The waste is nonhazardous/nonradioactive.
The unit is an excavated area between the 183-DR
and $190-0 R$ that contained four $3,750,000-g a 1$ steel
water storage tanks. The four tanks were removed.
Approximately $25 \%$ of the bottom surface area contains
a layer of waste 5 to 10 ft. deep that is covered with
pit run backfill and located in the northwest sector
of the pit. The southern sector is posted as an
asbestos area.

132-DR-1 1608-DR Waste Water Pumping Analogous with DR-1.

Station

$36^{\prime} \times 34^{\prime}$

The site was active from 1950 through 1964.

The site is included in the TPA action plan.

The waste is low level liquid waste.

The unit consisted of: 1) an above ground structure consisting of concrete block walls, a reinforced

concrete floor, and a roof reinforced concrete deck with a composition surface; and 2) a below-grade structure of reinforced concrete. The facility contained an operating level, which consisted of pumping equipment, and an accumulation inlet chamber, which led three discharge sump chambers. the accumulation chamber was located in the northern section of the facility.

132-DR-2 116-DR Reactor Exhaust Stack N/A $200^{\prime} \times 16.58^{\prime}$ diameter

The site was active from 1950 through 1986.

The site is not included in the TPA action plan. The waste is solid low level waste. The unit is monolithic, reinforced concrete structure with a maximum wall thickness of $1.5 \mathrm{ft}$. at the base. It rests on a double octagon shaped base that extends $17.5 \mathrm{ft}$. below grade. An opening at the base provides access to its interior portion. This opening is fitted with a steel door.

$1607-D-3$

1607-D3 Septic Tank and Associated

Defer?

Drain Field

The site was started in 1944 and is active at present. The site is included in the TPA action plan.

The site receives sanitary waste from the 151-D Electrical Distribution Substation. The flow rate to this unit is estimated at $1,050 \mathrm{gal} / \mathrm{d}$. 
WHC-SD-EN-TI-181, Rev. 0

\section{APPENDIX F \\ 100-DR-3 OPERABLE UNIT \\ WORK PLAN CHARACTERIZATION STRATEGY}


WHC-SD-EN-TI-181-Rev.0

This page intentionally left blank

-

$F-2$ 


\section{0-DR-3 Waste Sites}

118-D-1 (100-D Burial Ground No. 1)

The site is $450^{\prime} \times 375^{\prime} \times 20^{\prime}$.

The site was active from 1944 through 1967.

The site is included in the TPA action plan.

The site received 10,000 cubic meters of irradiated dumm:es, thimbles, rods, gun barrels, and other contaminated solid waste.

118-D-2 (100-D Burial Ground No. 2)

The site is $1,000^{\prime} \times 360^{\prime} \times 20^{\prime}$.

The site was active from 1949 through 1970 .

The site is included in the TPA action plan.

The site received 10,000 cubic meters of miscellaneous contaminated solid waste, irradiated dummies, splines, rods, thimbles, and gun barrels. After April 1966, 100-N Area solid wastes were al so buried here.

118-D-3 (100-D Burial Ground No. 3)

The site is $1000^{\prime} \times 250^{\prime} \times 20^{\prime}$.

The site was active from 1956 through 1973 .

The site is included in the TPA action plan.

The site received 100 cubic meters of miscellaneous contaminated solid wastes and irradiated dummies, splines, rods, thimbles, and gun barrels.

118-D-4 Construction Burial Ground

The site is $600^{\prime} \times 200^{\prime} \times 20^{\prime}$.

The site was active from 1953 through 1967.

The site is included in the TPA action plan.

The site received 20,000 cubic meters of contaminated material consisting mainly of reactor components and hardware.

118-DR-1 105-DR Gas Loop Burial Ground

The site is $125^{\prime} \times 75^{\prime} \times 15^{\prime}$.

The site was active from 1963 through 1964.

The site is included in the TPA action plan.

The site received 20 cubic meters of irradiated metal assemblies from the 105-DR Gas Loop.

128-D-1 100 D/DR Burning Pit

The site is $100^{\prime} \times 100^{\prime} \times 10^{\prime}$.

The site was active from 1944 through 1967.

The site is included in the TPA action plan.

The site received nonradioactive, combustible materials fuch as paint waste, office waste, and chemical solvents. 
1607-D1 1607-D1 Septic Tank Associated Drain Field 1607-D1 Sanitary Sewer System, 1607-D1 Septic Tank. The site was active from 1944 through 1965. The site is included in the TPA action plan. The site received sanitary waste from the 1701-D Badgehouse (security check point) and the 1709-D Patrol Change Room and offices, amount unknown. 
WHC-SD-EN-TI-181, Rev. 0

\section{DISTRIBUTION}

\section{Number of Copies}

ONSITE

M. R. Adams

H6-01

R. I. Carpenter (15)

H6-01

S. L. Cotè

H6-01

D. ii. DeFord

H6-01

M. W. Einan

K. A. Gano

H6-01

R. P. Henckel (4)

$\times 0-21$

J. E. Hodgson

H6-02

A. D. Krug (2)

$\mathrm{X} 7-02$

N. K. Naiknimbalkar

H6-02

J. K. Patterson

R. A. Winship

Central Files (2)

EDMC (2)

ERC

IRA (2)

H6-02

H6-27

A3-30

L8-04

H6-08

H6-07

H4-17 

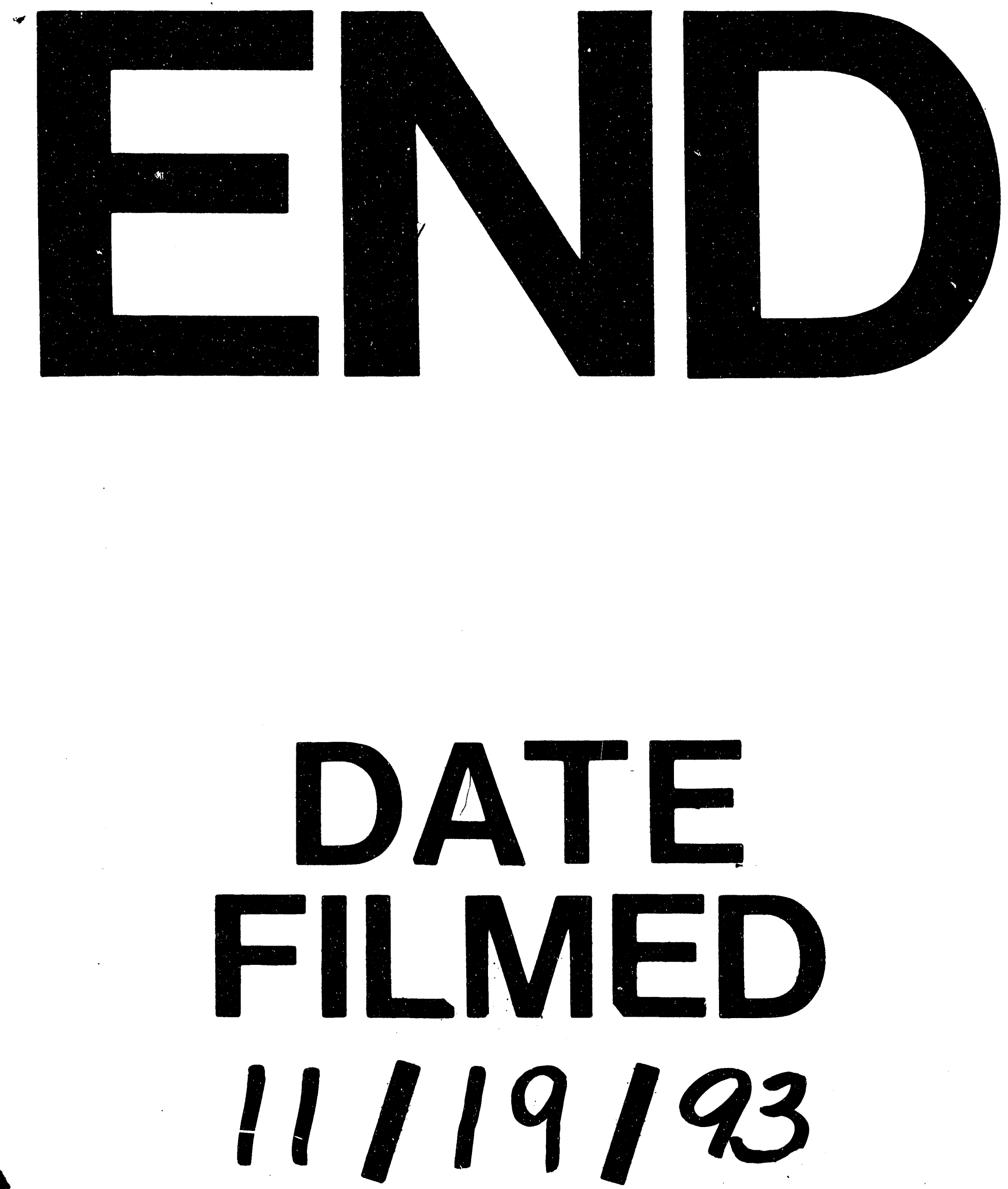
